\title{
Interim Measure Conceptual Design for Remediation at the Former CCC/USDA Grain Storage Facility at Centralia, Kansas: Pilot Test and Remedy Implementation
}

Environmental Science Division 


\begin{abstract}
About Argonne National Laboratory
Argonne is a U.S. Department of Energy laboratory managed by UChicago Argonne, LLC under contract DE-AC02-06CH11357. The Laboratory's main facility is outside Chicago, at 9700 South Cass Avenue, Argonne, Illinois 60439. For information about Argonne, see www.anl.gov.
\end{abstract}

\title{
Availability of This Report
}

This report is available, at no cost, at http://www.osti.gov/bridge. It is also available on paper to the U.S. Department of Energy and its contractors, for a processing fee, from:

U.S. Department of Energy

Office of Scientific and Technical Information

P.O. Box 62

Oak Ridge, TN 37831-0062

phone (865) 576-8401

fax (865) 576-5728

reports@adonis.osti.gov

\section{Disclaimer}

This report was prepared as an account of work sponsored by an agency of the United States Government. Reference herein to any specific commercial product, process, or service by trade name, trademark, manufacturer, or otherwise, does not necessarily constitute or imply its endorsement, recommendation, or favoring by the United States Government or any agency thereof. The views and opinions of document authors expressed herein do not necessarily state or reflect those of the United States Government or any agency thereof, Argonne National Laboratory, or UChicago Argonne, LLC. 


\section{Interim Measure Conceptual Design for Remediation at the Former CCC/USDA Grain Storage Facility at Centralia, Kansas: Pilot Test and Remedy Implementation}

by

Applied Geosciences and Environmental Management Section

Environmental Science Division, Argonne National Laboratory

October 2007 
Interim Remedial Measure for Centralia, Kansas: Conceptual Design and Pilot Test

Version 01, 10/23/07

\section{Contents}

Notation.

Executive Summary

ES-1

1 Introduction

$1-1$

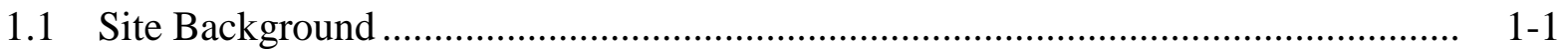

1.2 Results of Previous Investigations ............................................................... $1-2$

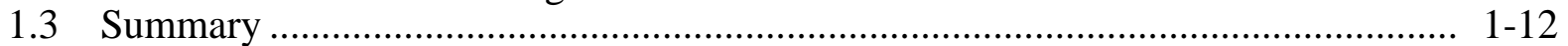

2 Description of the Recommended Interim Measure ............................................... 2-1

3 Interim Remedial Measure Objectives .................................................................

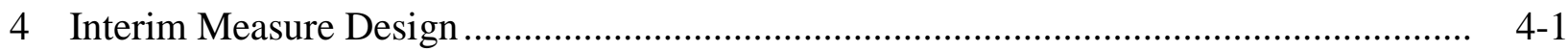

4.1 Design Basis ............................................................................................ 4-1

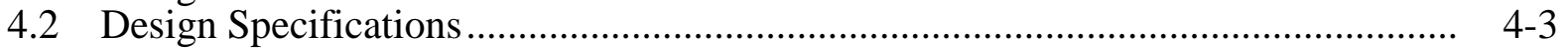

4.2.1 Pilot Test Treatment Area .............................................................. 4-3

4.2.2 Strategy for Injection of the ISCR Amendments ....................................

4.2.3 Pilot Test Monitoring Program ............................................................. 4. $4-5$

4.2.4 Performance Evaluation of the ISCR Remedial Approach ......................... 4-11

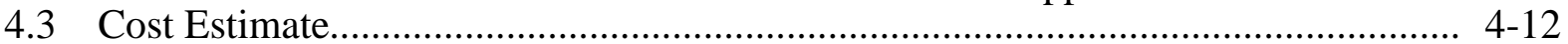

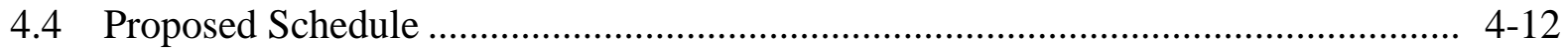

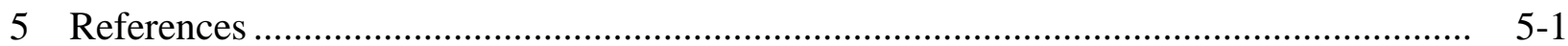

Appendix A: Slug Testing of Monitoring Wells and Piezometers at Centralia

(October 2006) .......................................................................... A-1

Appendix B: Studies on the Degradation of Carbon Tetrachloride in the

Presence of Zero-Valent Iron (February 2007) ....................................... B-1

Appendix C: Material Safety Data Sheets for EHC and EHC-A …............................... C-1 
Interim Remedial Measure for Centralia, Kansas: Conceptual Design and Pilot Test

\section{Tables}

1.1 Scoring of biodegradation processes at Centralia — March 2006 data ....................... 1-4

1.2 Analytical results for volatile organic compounds in groundwater samples collected at Centralia, August 2004 to March 2007

1.3 Scoring of biodegradation processes at Centralia - March 2007 data $1-10$

4.1 Summary of proposed monitoring activities for the recommended Interim Measure pilot test at Centralia

\section{Figures}

1.1 Locations of the former CCC/USDA facility and the contaminated private well at Centralia

1.2 Locations of near-surface soil sampling in 2002

1.3 Locations and results of vertical-profile soil sampling in 2002 and 2003

1.4 Southwest-northeast hydrogeologic cross section at Centralia, with results for carbon tetrachloride in vertical-profile groundwater samples collected in 2002 and 2003.

1.5 Lateral distribution of carbon tetrachloride in the shallow aquifer at Centralia, as interpreted from analytical results for 2002 and 2003

1.6 Monitoring network established in 2004, with the lateral distribution of carbon tetrachloride in the shallow aquifer at Centralia, as interpreted from analytical results for groundwater sampling in August 2004 and earlier.

1.7 Analytical results for carbon tetrachloride in groundwater samples collected in March 2007, with interpreted water level contours for March 2006, interpreted plume boundaries in 2004-2007, and analytical results for soil samples collected at SB12 in April 2003.

1.8 Water level contours for the shallow aquifer at Centralia on September 24, 2005, March 14-17, 2006, and June 16, 2006, as interpreted from measurements in a monitoring network expanded in January 2006 through the addition of wells MW07-MW10 
2.1 Analytical results for carbon tetrachloride in groundwater samples collected in the hot-spot areas in March 2007, with interpreted water level contours for March 2006, the interpreted plume boundary in March 2007, and the analytical results for carbon tetrachloride in soil at location SB12 in April 2003

4.1 Proposed pilot test area at Centralia, with locations of soil boring SB12 and MW02 (which define the hot-spot area to be treated in the pilot test) and nearby existing monitoring points

4.2 Proposed pilot test area at Centralia, with locations of injection points

4.3 Proposed pilot test area at Centralia, with locations of injection points and existing and new monitoring points 


\section{Notation}

BER Bureau of Environmental Remediation (KDHE)

BGL below ground level

${ }^{\circ} \mathrm{C}$

degree(s) Celsius

CCC Commodity Credit Corporation

CPT cone penetrometer

EPA U.S. Environmental Protection Agency

$\mathrm{ft} \quad$ foot (feet)

hr hour(s)

IM Interim Measure

in. inch(es)

ISCR in situ chemical reduction

KDHE Kansas Department of Health and Environment

$\mathrm{lb} \quad$ pound(s)

$\mu \mathrm{g} / \mathrm{kg} \quad$ microgram(s) per kilogram

$\mathrm{mg} / \mathrm{kg} \quad$ milligram(s) per kilogram

$\mu \mathrm{g} / \mathrm{L} \quad$ microgram(s) per liter

MCL maximum contaminant level

min minute(s)

MNA monitored natural attenuation

$\mathrm{mV} \quad$ millivolt(s)

ORP oxidation-reduction potential

ppb part(s) per billion

PVC polyvinyl chloride

RBSL Risk-Based Screening Level

USDA U.S. Department of Agriculture

VOC volatile organic compound

$\mathrm{yr} \quad$ year(s)

ZVI zero-valent iron 


\section{Interim Measure Conceptual Design for Remediation at the Former CCC/USDA Grain Storage Facility at Centralia, Kansas: Pilot Test and Remedy Implementation}

\section{Executive Summary}

This document presents an Interim Measure Work Plan/Design for the short-term, fieldscale pilot testing and subsequent implementation of a non-emergency Interim Measure (IM) at the site of the former grain storage facility operated by the Commodity Credit Corporation of the U.S. Department of Agriculture (CCC/USDA) in Centralia, Kansas. The IM is recommended to mitigate both (1) localized carbon tetrachloride contamination in the vadose zone soils beneath the former facility and (2) present (and potentially future) carbon tetrachloride contamination identified in the shallow groundwater beneath and in the immediate vicinity of the former CCC/USDA facility.

Investigations conducted on behalf of the CCC/USDA by Argonne National Laboratory have demonstrated that groundwater at the Centralia site is contaminated with carbon tetrachloride at levels that exceed the Kansas Tier 2 Risk-Based Screening Level (RBSL) and the U.S. Environmental Protection Agency's maximum contaminant level of $5.0 \mu \mathrm{g} / \mathrm{L}$ for this compound. Groundwater sampling and analyses conducted by Argonne under a monitoring program approved by the Kansas Department of Health and Environment (KDHE) indicated that the carbon tetrachloride levels at several locations in the groundwater plume have increased since twice yearly monitoring of the site began in September 2005. The identified groundwater contamination currently poses no unacceptable health risks, in view of the absence of potential human receptors in the vicinity of the former CCC/USDA facility.

Carbon tetrachloride contamination has also been identified at Centralia in subsurface soils at concentrations on the order of the Kansas Tier 2 RBSL of $200 \mu \mathrm{g} / \mathrm{kg}$ in soil for the soilto-groundwater protection pathway. Soils contaminated at this level might pose some risk as a potential source of carbon tetrachloride contamination to groundwater.

To mitigate the existing contaminant levels and decrease the potential future concentrations of carbon tetrachloride in groundwater and soil, the CCC/USDA recommends initial short-term, field-scale pilot testing of a remedial approach that employs in situ chemical reduction (ISCR), in the form of a commercially available material marketed by Adventus Americas, Inc., Freeport, Illinois (http://www.adventusgroup.com). If the pilot test is successful, 
it will be followed by a request for KDHE authorization of full implementation of the ISCR approach.

In the recommended ISCR approach, the Adventus $\mathrm{EHC}^{\circledR}$ material - a proprietary mixture of food-grade organic carbon and zero-valent iron - is introduced into the subsurface, where the components are released slowly into the formation. The compounds create highly reducing conditions in the saturated zone and the overlying vadose zone. These conditions foster chemical and biological reductive dechlorination of carbon tetrachloride. The anticipated effective lifetime of the EHC compounds following injection is 1-5 yr.

Although ISCR is a relatively innovative remedial approach, the EHC technology has been demonstrated to be effective in the treatment of carbon tetrachloride contamination in groundwater and has been employed at a carbon tetrachloride contamination site elsewhere in Kansas (Cargill Flour Mill and Elevator, Wellington, Kansas; KDHE Project Code C209670158), with the approval of the KDHE.

At Centralia, the CCC/USDA recommends use of the ISCR approach initially in a shortterm pilot test addressing the elevated carbon tetrachloride levels identified in one of three persistently highly contaminated areas ("hot-spot areas") in the groundwater plume. In this test, a three-dimensional grid pattern of direct-push injection points will be used to distribute the EHC material (in slurry or aqueous form) throughout the volume of the contaminated aquifer and (in selected locations) the vadose zone in the selected hot-spot area. Injection of the EHC material will be conducted by a licensed contractor, under the supervision of Adventus and Argonne technical personnel. The contractor will be identified upon acceptance by the KDHE of the conceptual design presented here. In the pilot test, Argonne will install and periodically sample a network of temporary and permanent monitoring points to document (1) the contaminant distribution in the saturated and vadose zones prior to injection, (2) the distribution of the EHC material in these zones immediately following injection, and (3) subsequent changes in contaminant concentrations that occur over time in response to the imposed treatment.

Argonne's investigations have shown that the lithologic properties of the unit hosting the contaminated aquifer at Centralia vary both vertically and laterally, resulting in a heterogeneous distribution of permeabilities and relatively restricted groundwater movement across much of the site. The initial short-term pilot test in the most contaminated of the three hot-spot areas is recommended to identify the operational techniques that will be required for optimal 
implementation and monitoring of the ISCR approach in the other two hot-spot areas and to verify the suitability of this approach for treating the carbon tetrachloride contamination at the Centralia site.

The results of three months of monitoring following injection of the EHC material in the pilot test area will be presented for review by the CCC/USDA and KDHE project managers. 


\section{Introduction}

This document presents an Interim Measure Work Plan/Design for the short-term, fieldscale pilot testing and subsequent implementation of a non-emergency Interim Measure (IM) at the site of the former grain storage facility operated by the Commodity Credit Corporation of the U.S. Department of Agriculture (CCC/USDA) in Centralia, Kansas. The IM is recommended to mitigate both (1) localized carbon tetrachloride contamination in the vadose zone soils beneath the former facility and (2) present (and potentially future) carbon tetrachloride contamination identified in the shallow groundwater beneath and in the immediate vicinity of the former CCC/USDA facility.

The conceptual design presented here was developed in accordance with the Kansas Department of Health and Environment (KDHE), Bureau of Environmental Remediation (BER), Policy \#BER-RS-029, Policy and Scope of Work: Interim Measures (KDHE 1996).

\subsection{Site Background}

In April 1998, the KDHE sampled a private domestic well at the Morris residence near Centralia as part of the CCC/USDA private well sampling program. This program had been initiated to determine whether carbon tetrachloride was present in domestic wells located near former CCC/USDA grain storage facilities in Kansas (Figure 1.1). Carbon tetrachloride was detected and confirmed in the Morris well at a concentration of $25.4 \mu \mathrm{g} / \mathrm{L}$. The sampling occurred on April 14, 1998, during the CCC/USDA private well sampling program. This concentration exceeds the Kansas Tier 2 Risk-Based Screening Level (RBSL) and the U.S. Environmental Protection Agency (EPA) maximum contaminant level (MCL) of $5.0 \mu \mathrm{g} / \mathrm{L}$ for carbon tetrachloride. On the basis of these findings, the KDHE conducted further preliminary studies in 1998 and identified carbon tetrachloride contamination on and near the site of a former CCC/USDA grain storage facility located approximately $3,500 \mathrm{ft}$ south of the contaminated private well (Argonne 2002a). No grain storage or other structures associated with the former $\mathrm{CCC} / \mathrm{USDA}$ facility remain at the site; it is presently vacant pastureland.

At the request of the CCC/USDA, Argonne subsequently conducted a phased series of investigations (from 2002 to 2004) to characterize the hydrogeologic setting and the distribution of carbon tetrachloride contamination at the former CCC/USDA facility (Argonne 2003, 2004). The results of these studies and subsequent monitoring activities are summarized in Section 1.2. 


\subsection{Results of Previous Investigations}

Purge-and-trap analyses of near-surface and deeper subsurface vadose zone soil samples collected by Argonne at the former CCC/USDA facility in 2002 and 2003 (Figures 1.2 and 1.3, respectively; originally reported in Argonne 2003, 2004) detected no concentrations of carbon tetrachloride in soils at levels exceeding the Kansas RBSLs for direct contact under either the residential or the non-residential exposure scenario $(2.5 \mathrm{mg} / \mathrm{kg}$ or $7.0 \mathrm{mg} / \mathrm{kg}$, respectively; KDHE 2007a). Carbon tetrachloride contamination was identified in subsurface soils at concentrations greater than $100 \mu \mathrm{g} / \mathrm{kg}$ in three small areas around locations SB06, SB12, and SB24 (Figure 1.3). Maximum carbon tetrachloride levels in vadose zone soils ranging from $202 \mu \mathrm{g} / \mathrm{kg}$ to $219 \mu \mathrm{g} / \mathrm{kg}$ were identified over a depth interval of approximately $20 \mathrm{ft}$ at one location only (SB12); these levels are on the order of the Kansas Tier $2 \mathrm{RBSL}$ of $200 \mu \mathrm{g} / \mathrm{kg}$ in soil for the soil-to-groundwater protection pathway (KDHE 2007a), and hence they may pose some risk as a potential source of carbon tetrachloride contamination to groundwater.

The results of groundwater characterization studies performed by Argonne (2003, 2004) demonstrated carbon tetrachloride contamination associated with the former CCC/USDA grain storage facility at levels above the RBSL and the MCL. The contamination occurs in a shallow aquifer consisting of glacial outwash sediments ranging from fine grained silts and clay to gravely, medium to coarse sands (Figure 1.4). The identified groundwater plume is limited in extent and is unrelated to the contamination originally identified by the KDHE at the Morris private well. The contamination in groundwater at the former CCC/USDA facility is restricted vertically to the upper portion of the saturated zone (Figure 1.4) and laterally to the vicinity of the former facility boundary (Figure 1.5). Whether the contamination in the Morris private well has been investigated or resolved is unknown.

High levels of chloroform (in comparison to carbon tetrachloride) were detected at several locations in the groundwater plume during the phased characterization studies (Argonne 2003, 2004). Together with the observed aquifer heterogeneity and plume morphology (see below), the relative abundance of chloroform suggests that the rates of groundwater flow and contaminant migration at the former CCC/USDA facility are limited. The relative concentrations of chloroform, a primary degradation product of carbon tetrachloride, suggest that some degree of reductive dechlorination or natural biodegradation of carbon tetrachloride might be taking place in situ at the former CCC/USDA facility. The probability of observing this anaerobic process is increased in groundwater systems that experience restricted circulation and limited mixing with recent, oxygenated waters. 
With the approval of the KDHE, a network of 12 permanent groundwater sampling and monitoring points (piezometers SB01, SB04, SB05, SB07, SB08, and SB09, as well as monitoring wells MW1-MW6; Figure 1.6) was established in 2004 (Argonne 2005b). The purposes of this network were to (1) confirm the lateral extent of the carbon tetrachloride plume, (2) track any contaminant migration that might occur, and (3) provide sampling points for the collection of geochemical data that could be used to evaluate the in situ potential for natural attenuation of the existing plume. Initial sampling of the complete monitoring network was performed in August 2004 (Figure 1.6). A preliminary quantitative screening of the August 2004 results with the technical protocol for evaluation of natural attenuation of chlorinated solvents in groundwater (EPA 1998) indicated that conditions at some locations in the aquifer might be suitable for natural in situ biodegradation of carbon tetrachloride through reductive dechlorination (Table 4.1 in Argonne 2005b). A second evaluation based on March 2006 data (as well as dissolved hydrogen values obtained in September 2005) gave somewhat higher scores, but the evidence for reductive dechlorination was still "limited" (Table 1.1; see also Argonne 2006a).

The carbon tetrachloride plume at Centralia does not exhibit the elongated geometry typically associated with groundwater flow and advection-dominated contaminant migration. Instead, the areal distribution of carbon tetrachloride in the groundwater plume is highly heterogeneous, with the most elevated, most persistent concentrations (greater than $100 \mu \mathrm{g} / \mathrm{L}$ in recent monitoring) occurring in three seemingly isolated hot-spot areas. These areas are located near the north-central (SB08-MW02), western (SB05), and southwestern (SB01) boundaries of the former facility (Figure 1.7). These observations are consistent with groundwater levels, estimated hydraulic conductivity values (Appendix A), and apparent hydraulic gradients determined for the site (Figure 1.8). All of these data confirm that groundwater movement beneath much of the former CCC/USDA facility is sluggish. Flow rates were estimated on the basis of the slug tests results reported in Appendix A and water levels measured on June 16, 2006 (Figure 1.8). The resulting flow rates were $\leq 0.2 \mathrm{ft} /$ day and $<1.0 \mathrm{ft} /$ day, respectively, near the southern and western margins of the former CCC/USDA facility. In the eastern part of the property, the gradient is low but uncertain, and no estimates of flow rate could be made.

With the approval of the KDHE, the CCC/USDA initiated a program of extended groundwater geochemical sampling and water level monitoring at Centralia in September 2005 (Argonne 2005a,c). The monitoring was recommended for a 2 -yr period. The objectives of this 
TABLE 1.1 Scoring of biodegradation processes at Centralia - March 2006 data. $^{a}$

\begin{tabular}{|c|c|c|c|c|c|c|c|c|c|c|c|c|c|c|c|c|c|}
\hline \multirow[b]{2}{*}{ Constituent } & \multirow[b]{2}{*}{ Units } & \multicolumn{2}{|c|}{ MW01 } & \multicolumn{2}{|c|}{ MW02 } & \multicolumn{2}{|c|}{ MW03 } & \multicolumn{2}{|c|}{ MW04 } & \multicolumn{2}{|c|}{ MW05 } & \multicolumn{2}{|c|}{ MW06 } & \multicolumn{2}{|c|}{ MW07 } & \multicolumn{2}{|c|}{ MW08 } \\
\hline & & Conc. & Points & Conc. & Points & Conc. & Points & Conc. & Points & Conc. & Points & Conc. & Points & Conc. & Points & Conc. & Points \\
\hline Dissolved Oxygen & $\mathrm{mg} / \mathrm{L}$ & 9.33 & -3 & 1.24 & 0 & 9.39 & 0 & 6.82 & -3 & 0.9 & 0 & 9.87 & -3 & 0.34 & 3 & 5.32 & -3 \\
\hline Nitrate & $\mathrm{mg} / \mathrm{L}$ & 0.82 & 2 & 9.92 & 0 & 9.17 & 0 & 4.97 & 0 & 3.36 & 0 & 0.524 & 2 & 1.18 & 0 & 2.47 & 0 \\
\hline Iron(II) & $\mathrm{mg} / \mathrm{L}$ & 0.04 & 0 & 0 & 0 & 0 & 0 & 0.06 & 0 & 0.06 & 0 & 0.02 & 0 & 0.03 & 0 & 0 & 0 \\
\hline Sulfate & $\mathrm{mg} / \mathrm{L}$ & 6.3 & 2 & 12.2 & 2 & 9.15 & 2 & 6.38 & 2 & 5.17 & 2 & 5 & 2 & 28.5 & 0 & 14.4 & 2 \\
\hline Sulfide & $\mathrm{mg} / \mathrm{L}$ & $<0.02$ & 0 & 0.0381 & 0 & $<0.02$ & 0 & 0.0794 & 0 & $<0.02$ & 0 & $<0.02$ & 0 & $<0.02$ & 0 & $<0.02$ & 0 \\
\hline Methane & $\mathrm{mg} / \mathrm{L}$ & $<0.002$ & 0 & 0.034 & 0 & $<0.002$ & 0 & 0.051 & 0 & $<0.002$ & 0 & 0.0023 & 0 & $<0.002$ & 0 & $<0.002$ & 0 \\
\hline ORP & $\mathrm{mV}$ & 297 & 0 & 295 & 0 & 290 & 0 & 283 & 0 & 156 & 0 & 263 & 0 & 143 & 0 & 145 & 0 \\
\hline $\mathrm{pH}$ & - & 7.56 & 0 & 6.78 & 0 & 6.75 & 0 & 7.78 & 0 & 6.9 & 0 & 7.38 & 0 & 6.61 & 0 & 6.35 & 0 \\
\hline Total Organic Carbon & $\mathrm{mg} / \mathrm{L}$ & 6.19 & 0 & 3.57 & 0 & 1.23 & 0 & 5.07 & 0 & 5.54 & 0 & 4.12 & 0 & 35.4 & 2 & 9 & 0 \\
\hline Temperature & ${ }^{\circ} \mathrm{C}$ & 14.3 & 0 & 14.2 & 0 & 13.8 & 0 & 13.5 & 0 & 14.3 & 0 & 14.1 & 0 & 14.7 & 0 & 13.5 & 0 \\
\hline Carbon Dioxide ${ }^{b}$ & $\mathrm{mg} / \mathrm{L}$ & 30 & 0 & $\mathrm{NR}^{\mathrm{c}}$ & - & 77 & 1 & 55 & 0 & 30 & 0 & 35 & 0 & NR & - & NR & - \\
\hline Alkalinity $^{\mathrm{b}}$ & $\mathrm{mg} / \mathrm{L}$ & 325 & 0 & 364 & 0 & 353 & 0 & 337 & 0 & 304 & 0 & 343 & 0 & 299 & 0 & 342 & 0 \\
\hline Chloride $^{b}$ & $\mathrm{mg} / \mathrm{L}$ & 14.9 & 0 & 8.45 & 0 & 24 & 0 & 11.9 & 0 & 9.66 & 0 & 8.98 & 0 & 8.72 & 0 & 47.4 & 2 \\
\hline Dissolved Hydrogen & $\mathrm{nM}$ & $N A^{d}$ & - & $3.1^{\mathrm{e}}$ & 3 & NA & - & NA & - & NA & - & NA & - & NA & - & NA & - \\
\hline Chloroform & $\mu g / L$ & $N D^{f}$ & 0 & 21 & 2 & $0.2 \mathrm{Jg}$ & 2 & ND & 0 & ND & 0 & ND & 0 & $0.6 \mathrm{~J}$ & 2 & ND & 0 \\
\hline \multirow{3}{*}{$\begin{array}{l}\text { Dichloromethane } \\
\text { (methylene chloride) }\end{array}$} & & & & & & & & & & & & & & & & & \\
\hline & $\mu \mathrm{g} / \mathrm{L}$ & ND & 0 & ND & 0 & ND & 0 & ND & 0 & ND & 0 & ND & 0 & ND & 0 & ND & 0 \\
\hline & \multicolumn{2}{|c|}{ Total points $=>$} & 1 & & 7 & & 5 & & -1 & & 2 & & 1 & & 7 & & 1 \\
\hline
\end{tabular}


TABLE 1.1 (Cont.)

\begin{tabular}{|c|c|c|c|c|c|c|c|c|c|c|c|c|c|c|c|c|c|}
\hline \multirow[b]{2}{*}{ Constituent } & \multirow[b]{2}{*}{ Units } & \multicolumn{2}{|c|}{ MW09 } & \multicolumn{2}{|c|}{ MW10 } & \multicolumn{2}{|c|}{ SB01 } & \multicolumn{2}{|c|}{ SB04 } & \multicolumn{2}{|c|}{ SB05 } & \multicolumn{2}{|c|}{ SB07R } & \multicolumn{2}{|c|}{ SB08 } & \multicolumn{2}{|c|}{ SB09 } \\
\hline & & Conc. & Points & Conc. & Points & Conc. & Points & Conc. & Points & Conc. & Points & Conc. & Points & Conc. & Points & Conc. & Points \\
\hline Dissolved Oxygen & $\mathrm{mg} / \mathrm{L}$ & 0.95 & 0 & 6.42 & -3 & 5.98 & -3 & 5.96 & -3 & 4.8 & 0 & 7.41 & -3 & 3.4 & 0 & 1.53 & 0 \\
\hline Nitrate & $\mathrm{mg} / \mathrm{L}$ & 3.25 & 0 & 1.23 & 0 & 1.14 & 0 & 3.07 & 0 & 2.56 & 0 & 1.27 & 0 & 1.69 & 0 & 4.67 & 0 \\
\hline Iron(II) & $\mathrm{mg} / \mathrm{L}$ & 0.09 & 0 & 0 & 0 & 0 & 0 & NR & - & 0.18 & 0 & 0.08 & 0 & 0 & 0 & 0 & 0 \\
\hline Sulfate & $\mathrm{mg} / \mathrm{L}$ & 6.23 & 2 & 10.8 & 2 & 4.87 & 2 & 5.98 & 2 & 2.96 & 2 & 16.8 & 2 & 9.25 & 2 & 38.8 & 0 \\
\hline Sulfide & $\mathrm{mg} / \mathrm{L}$ & $<0.02$ & 0 & $<0.02$ & 0 & $<0.02$ & 0 & $<0.02$ & 0 & $<0.02$ & 0 & $<0.02$ & 0 & $<0.02$ & 0 & $<0.02$ & 0 \\
\hline Methane & $\mathrm{mg} / \mathrm{L}$ & $<0.002$ & 0 & $<0.002$ & 0 & $<0.002$ & 0 & $<0.002$ & 0 & $<0.002$ & 0 & $<0.002$ & 0 & $<0.002$ & 0 & $<0.002$ & 0 \\
\hline ORP & $\mathrm{mV}$ & 214 & 0 & 166 & 0 & 185 & 0 & 276 & 0 & 253 & 0 & 83 & 0 & 246 & 0 & 206 & 0 \\
\hline $\mathrm{pH}$ & - & 7.33 & 0 & 6.6 & 0 & 7.3 & 0 & 7.57 & 0 & 7.67 & 0 & 7.24 & 0 & 7.14 & 0 & 7.03 & 0 \\
\hline Total Organic Carbon & $\mathrm{mg} / \mathrm{L}$ & 10.7 & 0 & 7.96 & 0 & 8.97 & 0 & 3.78 & 0 & 4.97 & 0 & 11.2 & 0 & 5.99 & 0 & 6.88 & 0 \\
\hline Temperature & ${ }^{\circ} \mathrm{C}$ & 17.7 & 0 & 14.8 & 0 & 12.4 & 0 & 13 & 0 & 13.3 & 0 & 16.8 & 0 & 12.9 & 0 & 11.7 & 0 \\
\hline Carbon Dioxide ${ }^{b}$ & $\mathrm{mg} / \mathrm{L}$ & 55 & 0 & 65 & 1 & 55 & 0 & 30 & 0 & 40 & 0 & 60 & 1 & 40 & 0 & 99 & 1 \\
\hline Alkalinity $^{\mathrm{b}}$ & $\mathrm{mg} / \mathrm{L}$ & 329 & 0 & 298 & 0 & 338 & 0 & 371 & 0 & 324 & 0 & 318 & 0 & 327 & 0 & 495 & 0 \\
\hline Chloride $^{b}$ & $\mathrm{mg} / \mathrm{L}$ & 6.39 & 0 & 74.3 & 2 & 22.5 & 0 & 40 & 2 & 57.1 & 2 & 30.4 & 2 & 19.3 & 0 & 15.6 & 0 \\
\hline Dissolved Hydrogen & $\mathrm{nM}$ & NA & - & NA & - & $71^{a}$ & 3 & $24^{a}$ & 3 & $11^{a}$ & 3 & NA & - & $6.1^{a}$ & 3 & NA & - \\
\hline & $\mu g / L$ & ND & 0 & ND & 0 & 5.7 & 2 & $0.5 \mathrm{~J}$ & 2 & 7.2 & 2 & 2.7 & 2 & 2.7 & 2 & ND & 0 \\
\hline \multirow{3}{*}{$\begin{array}{l}\text { Dichloromethane } \\
\text { (methylene chloride) }\end{array}$} & & & & & & & & & & & & & & & & & \\
\hline & $\mu \mathrm{g} / \mathrm{L}$ & ND & 0 & ND & 0 & ND & 0 & ND & 0 & ND & 0 & ND & 0 & ND & 0 & ND & 0 \\
\hline & \multicolumn{2}{|c|}{ Total points => } & 2 & & 2 & & 4 & & 6 & & 9 & & 4 & & 7 & & 1 \\
\hline
\end{tabular}

a Scoring is based on results for samples collected in March 2006. Points are interpreted as follows (EPA 1998):

$\begin{array}{ll}0-5 & \text { Inadequate evidence for reductive dechlorination. } \\ 6-14 & \text { Limited evidence for reductive dechlorination. }\end{array}$

$\begin{array}{ll}15-20 & \text { Adequate evidence for reductive dechlorination } \\ >20 & \text { Strong evidence for reductive dechlorination. }\end{array}$ ${ }^{\mathrm{b}}$ For evaluation of alkalinity, carbon dioxide, and chloride, MW01 (because of its location) was selected to represent background levels. For these constituents, points are awarded when the

${ }^{c} \mathrm{NR}$, not recorded.

d NA, not analyzed for dissolved hydrogen in March 2006.

e Dissolved hydrogen result from September 2005 sampling.

${ }^{f} \mathrm{ND}$, not detected at an instrument detection limit of $0.1 \mu \mathrm{g} / \mathrm{L}$.

$g$ Qualifier $\mathrm{J}$ indicates an estimated concentration below the method quantitation limit of $1.0 \mu \mathrm{g} / \mathrm{L}$. 
program are to (1) document the physical and geochemical evolution of the carbon tetrachloride plume and (2) collect data necessary to evaluate the viability of monitored natural attenuation (MNA) as a possible remedial option for this site. The monitoring program was designed to provide data in keeping with KDHE Policy \#BER-RS-042 for the evaluation of MNA (KDHE 2001). Twice yearly sampling of groundwater for analyses for volatile organic compounds (VOCs) and selected geochemical indicator parameters required under Policy \#BER-RS-042 began at the site in September-October 2005 (Argonne 2005c). At the request of the KDHE, the monitoring well network was expanded in January 2006 to include four additional monitoring wells, MW07-MW10 (Argonne 2006a; Figure 1.8).

Regular sampling continued in September 2006 (Argonne 2006b). The most recent sampling event, marking approximately 18 months of monitoring under this program, was completed in March 2007 (Argonne 2007). The results of VOCs analyses for groundwater samples collected during the monitoring program are summarized in Table 1.2, together with VOCs results for the initial sampling of the monitoring well network in August 2004. The March 2007 results are illustrated, in historical context, in Figure 1.7. The results of screening of the March 2007 data with the EPA protocol for evaluating natural attenuation (EPA 1998) are in Table 1.3.

Evaluation of the 2007 monitoring data according to the EPA (1998) protocol confirmed the earlier finding of limited quantitative evidence for natural degradation of carbon tetrachloride at some locations in the carbon tetrachloride plume at Centralia. Despite this observation, however, the concentrations of carbon tetrachloride at sampling locations in the plume have shown no significant decreases with time; carbon tetrachloride levels at most of the sampled locations in the plume, particularly those in the previously identified hot-spot areas (SB01, SB05, and SB08-MW02) have remained relatively unchanged or have increased significantly since the August 2004 sampling event (Table 1.2). Of the three identified hot-spot areas, only the location near monitoring well MW02 shows a possible association with carbon tetrachloride contamination identified in the overlying vadose zone soils (at investigative boring SB12, as described above). Figure 1.7 illustrates this relationship and also indicates slow expansion of the groundwater plume along its south and southwest margins. The estimated maximum extension of approximately $50 \mathrm{ft}$ in the plume boundary (near MW04 and MW07) from August 2004 to March 2007 is in keeping with the patterns of groundwater flow identified at the site during that same period of record. 
TABLE 1.2 Analytical results for volatile organic compounds in groundwater samples collected at Centralia, August 2004 to March 2007.

\begin{tabular}{|c|c|c|c|c|c|}
\hline \multirow[b]{2}{*}{ Well } & \multirow{2}{*}{$\begin{array}{l}\text { Screen } \\
\text { Interval } \\
\text { (ft BGL) }\end{array}$} & \multirow[b]{2}{*}{$\begin{array}{l}\text { Sample } \\
\text { Date }\end{array}$} & \multicolumn{3}{|c|}{ Concentration $(\mu \mathrm{g} / \mathrm{L})$} \\
\hline & & & $\begin{array}{c}\text { Carbon } \\
\text { Tetrachloride }\end{array}$ & Chloroform & $\begin{array}{l}\text { Methylene } \\
\text { Chloride }\end{array}$ \\
\hline \multirow[t]{6}{*}{ MW01 } & $54.5-64.5$ & $8 / 24 / 04$ & $N D^{a}$ & ND & ND \\
\hline & & $9 / 10 / 05$ & ND & ND & ND \\
\hline & & $10 / 11 / 05$ & ND & ND & ND \\
\hline & & $3 / 15 / 06$ & ND & ND & ND \\
\hline & & $9 / 25 / 06$ & ND & ND & ND \\
\hline & & $3 / 29 / 07$ & ND & ND & ND \\
\hline \multirow[t]{6}{*}{ MW02 } & $49.5-59.5$ & $8 / 26 / 04$ & 215 & 6.2 & ND \\
\hline & & $9 / 11 / 05$ & 776 & 33 & ND \\
\hline & & $10 / 12 / 05$ & 528 & 21 & ND \\
\hline & & $3 / 16 / 06$ & 847 & 21 & ND \\
\hline & & $9 / 26 / 06$ & 1233 & 25 & ND \\
\hline & & $3 / 26 / 07$ & 829 & 14 & ND \\
\hline \multirow[t]{6}{*}{ MW03 } & $50.5-60.5$ & $8 / 24 / 04$ & 1.2 & ND & ND \\
\hline & & $9 / 10 / 05$ & 1.6 & ND & ND \\
\hline & & $10 / 11 / 05$ & 1.8 & ND & ND \\
\hline & & $3 / 17 / 06$ & 2.6 & $0.2 \mathrm{~J}^{\mathrm{b}}$ & ND \\
\hline & & $9 / 26 / 06$ & 2.7 & ND & ND \\
\hline & & $3 / 27 / 07$ & 2.5 & ND & ND \\
\hline \multirow[t]{6}{*}{ MW04 } & $37.5-47.5$ & $8 / 24 / 04$ & ND & ND & ND \\
\hline & & $9 / 11 / 05$ & $0.9 \mathrm{~J}$ & ND & ND \\
\hline & & $10 / 11 / 05$ & $0.8 \mathrm{~J}$ & ND & ND \\
\hline & & $3 / 15 / 06$ & 1.3 & ND & ND \\
\hline & & $9 / 25 / 06$ & 1.4 & $0.1 \mathrm{~J}$ & ND \\
\hline & & $3 / 28 / 07$ & 2.1 & ND & ND \\
\hline \multirow[t]{6}{*}{ MW05 } & $34.5-44.5$ & $8 / 25 / 04$ & ND & ND & ND \\
\hline & & 9/10/05 & 1.9 & ND & ND \\
\hline & & $10 / 11 / 05$ & 1.5 & ND & ND \\
\hline & & $3 / 15 / 06$ & 1.3 & ND & ND \\
\hline & & $9 / 25 / 06$ & 1.3 & ND & ND \\
\hline & & $3 / 28 / 07$ & $0.5 \mathrm{~J}$ & ND & ND \\
\hline
\end{tabular}


TABLE 1.2 (Cont.)

\begin{tabular}{|c|c|c|c|c|c|}
\hline \multirow[b]{2}{*}{ Well } & \multirow{2}{*}{$\begin{array}{l}\text { Screen } \\
\text { Interval } \\
\text { (ft BGL) }\end{array}$} & \multirow[b]{2}{*}{$\begin{array}{l}\text { Sample } \\
\text { Date }\end{array}$} & \multicolumn{3}{|c|}{ Concentration $(\mu \mathrm{g} / \mathrm{L})$} \\
\hline & & & $\begin{array}{c}\text { Carbon } \\
\text { Tetrachloride }\end{array}$ & Chloroform & $\begin{array}{l}\text { Methylene } \\
\text { Chloride }\end{array}$ \\
\hline \multirow[t]{6}{*}{ MW06 } & $46.5-56.5$ & $8 / 25 / 04$ & ND & ND & ND \\
\hline & & $9 / 10 / 05$ & ND & ND & ND \\
\hline & & $10 / 11 / 05$ & $0.3 \mathrm{~J}$ & ND & ND \\
\hline & & $3 / 15 / 06$ & $0.2 \mathrm{~J}$ & ND & ND \\
\hline & & 9/27/06 & ND & ND & ND \\
\hline & & $3 / 27 / 07$ & ND & ND & ND \\
\hline \multirow[t]{3}{*}{ MW07 } & $45-55$ & $3 / 14 / 06$ & $0.4 \mathrm{~J}$ & $0.6 \mathrm{~J}$ & ND \\
\hline & & 9/26/06 & 1.1 & ND & ND \\
\hline & & $3 / 26 / 07$ & 1.8 & ND & ND \\
\hline \multirow[t]{3}{*}{ MW08 } & $38-53$ & $3 / 14 / 06$ & ND & ND & ND \\
\hline & & $9 / 26 / 06$ & ND & ND & ND \\
\hline & & $3 / 27 / 07$ & ND & ND & ND \\
\hline \multirow[t]{3}{*}{ MW09 } & $25-35$ & $3 / 15 / 06$ & ND & ND & ND \\
\hline & & $9 / 25 / 06$ & ND & ND & ND \\
\hline & & $3 / 27 / 07$ & ND & ND & ND \\
\hline \multirow[t]{3}{*}{ MW10 } & $30-45$ & $3 / 14 / 06$ & ND & ND & ND \\
\hline & & 9/26/06 & ND & ND & ND \\
\hline & & $3 / 28 / 07$ & ND & ND & ND \\
\hline \multirow[t]{6}{*}{ SB01 } & $40-50$ & $8 / 26 / 04$ & 186 & 6.5 & ND \\
\hline & & $9 / 9 / 05$ & 269 & 6.8 & ND \\
\hline & & $10 / 12 / 05$ & 288 & 6.6 & ND \\
\hline & & $3 / 17 / 06$ & 320 & 5.7 & ND \\
\hline & & $9 / 27 / 06$ & 267 & 6.3 & ND \\
\hline & & $3 / 27 / 07$ & 222 & 4.9 & ND \\
\hline \multirow[t]{6}{*}{ SB04 } & $51-61$ & 8/26/04 & 30 & ND & ND \\
\hline & & $9 / 9 / 05$ & 47 & $0.6 \mathrm{~J}$ & ND \\
\hline & & $10 / 12 / 05$ & 44 & $0.5 \mathrm{~J}$ & ND \\
\hline & & $3 / 16 / 06$ & 51 & $0.5 \mathrm{~J}$ & $0.4 \mathrm{~J} \mathrm{~B}^{\mathrm{C}}$ \\
\hline & & $9 / 25 / 06$ & 54 & $0.7 \mathrm{~J}$ & ND \\
\hline & & $3 / 28 / 07$ & 44 & $0.5 \mathrm{~J}$ & ND \\
\hline
\end{tabular}


TABLE 1.2 (Cont.)

\begin{tabular}{|c|c|c|c|c|c|}
\hline \multirow[b]{2}{*}{ Well } & \multirow[b]{2}{*}{$\begin{array}{l}\text { Screen } \\
\text { Interval } \\
\text { (ft BGL) }\end{array}$} & \multirow[b]{2}{*}{$\begin{array}{l}\text { Sample } \\
\text { Date }\end{array}$} & \multicolumn{3}{|c|}{ Concentration $(\mu \mathrm{g} / \mathrm{L})$} \\
\hline & & & $\begin{array}{c}\text { Carbon } \\
\text { Tetrachloride }\end{array}$ & Chloroform & $\begin{array}{c}\text { Methylene } \\
\text { Chloride }\end{array}$ \\
\hline \multirow[t]{6}{*}{ SB05 } & 32-42 & 8/26/04 & 59 & 5.5 & ND \\
\hline & & $9 / 9 / 05$ & 77 & 7.2 & ND \\
\hline & & $10 / 12 / 05$ & 54 & 5.5 & ND \\
\hline & & $3 / 17 / 06$ & 104 & 7.2 & ND \\
\hline & & $9 / 27 / 06$ & 139 & 12 & ND \\
\hline & & $3 / 28 / 07$ & 138 & 12 & ND \\
\hline \multirow[t]{3}{*}{ SB07R } & $45-60$ & $3 / 15 / 06$ & 41 & 2.7 & ND \\
\hline & & $9 / 26 / 06$ & 30 & 1.7 & ND \\
\hline & & $3 / 26 / 07$ & 30 & 1.7 & ND \\
\hline \multirow[t]{6}{*}{ SB08 } & $52-62$ & 8/26/04 & 79 & 3.1 & ND \\
\hline & & $9 / 8 / 05$ & 80 & 2.6 & ND \\
\hline & & $10 / 12 / 05$ & 77 & 2.8 & ND \\
\hline & & $3 / 17 / 06$ & 91 & 2.7 & ND \\
\hline & & $9 / 21 / 06$ & 53 & 1.6 & ND \\
\hline & & $3 / 28 / 07$ & 64 & 2.0 & ND \\
\hline \multirow[t]{6}{*}{ SB09 } & $32-42$ & $8 / 26 / 04$ & ND & ND & ND \\
\hline & & $9 / 11 / 05$ & ND & ND & ND \\
\hline & & $10 / 11 / 05$ & ND & ND & ND \\
\hline & & $3 / 17 / 06$ & ND & ND & ND \\
\hline & & $9 / 25 / 06$ & ND & ND & ND \\
\hline & & $3 / 28 / 07$ & ND & ND & ND \\
\hline
\end{tabular}

a ND, not detected at an instrument detection limit of $0.1 \mu \mathrm{g} / \mathrm{L}$.

b Qualifier J indicates an estimated concentration below the method quantitation limit of $1.0 \mu \mathrm{g} / \mathrm{L}$.

c Qualifier B indicates that the contaminant was present in the associated method blank. 
TABLE 1.3 Scoring of biodegradation processes at Centralia - March 2007 data. ${ }^{\mathrm{a}}$

\begin{tabular}{|c|c|c|c|c|c|c|c|c|c|c|c|c|c|c|c|c|c|}
\hline \multirow[b]{2}{*}{ Constituent } & \multirow[b]{2}{*}{ Units } & \multicolumn{2}{|c|}{ MW01 } & \multicolumn{2}{|c|}{ MW02 } & \multicolumn{2}{|c|}{ MW03 } & \multicolumn{2}{|c|}{ MW04 } & \multicolumn{2}{|c|}{ MW05 } & \multicolumn{2}{|c|}{ MW06 } & \multicolumn{2}{|c|}{ MW07 } & \multicolumn{2}{|c|}{ MW08 } \\
\hline & & Conc. & Points & Conc. & Points & Conc. & Points & Conc. & Points & Conc. & Points & Conc. & Points & Conc. & Points & Conc. & Points \\
\hline Dissolved Oxygen & $\mathrm{mg} / \mathrm{L}$ & 4.39 & 0 & 2.29 & 0 & 7.73 & -3 & 5.46 & -3 & 4.53 & 0 & 0.11 & 3 & 1.87 & 0 & 1.49 & 0 \\
\hline Nitrate & $\mathrm{mg} / \mathrm{L}$ & 0.23 & 2 & 9 & 0 & 9.7 & 0 & 2.6 & 0 & 2 & 0 & 0.044 & 2 & 0.71 & 2 & 3.2 & 0 \\
\hline Iron(II) & $\mathrm{mg} / \mathrm{L}$ & 0 & 0 & $\mathrm{NR}^{\mathrm{c}}$ & - & NR & - & 0 & 0 & 0 & 0 & 0 & 0 & 0 & 0 & 0.21 & 0 \\
\hline Sulfate & $\mathrm{mg} / \mathrm{L}$ & 5 & 2 & 15 & 2 & 7.6 & 2 & 5.1 & 2 & 3 & 2 & 5.2 & 2 & 20 & 0 & 11 & 2 \\
\hline Sulfide & $\mathrm{mg} / \mathrm{L}$ & $<0.02$ & 0 & $<0.02$ & 0 & $<0.02$ & 0 & 0.027 & 0 & $<0.02$ & 0 & $<0.02$ & 0 & $<0.02$ & 0 & $<0.02$ & 0 \\
\hline Methane & $\mathrm{mg} / \mathrm{L}$ & $<0.002$ & 0 & 0.021 & 0 & $<0.002$ & 0 & 0.0062 & 0 & $<0.002$ & 0 & 0.0065 & 0 & $<0.002$ & 0 & $<0.002$ & 0 \\
\hline ORP & $\mathrm{mV}$ & 174 & 0 & 67 & 0 & 268 & 0 & 197 & 0 & 295 & 0 & 13 & 1 & 261 & 0 & 237 & 0 \\
\hline $\mathrm{pH}$ & - & 6.54 & 0 & 6.39 & 0 & 6.4 & 0 & 6.47 & 0 & 6.44 & 0 & 6.42 & 0 & 6.5 & 0 & 6.31 & 0 \\
\hline Total Organic Carbon & $\mathrm{mg} / \mathrm{L}$ & $<1$ & 0 & 1.1 & 0 & $<1$ & 0 & $<1$ & 0 & $<1$ & 0 & 4 & 0 & 1 & 0 & 1.9 & 0 \\
\hline Temperature & ${ }^{\circ} \mathrm{C}$ & 16.5 & 0 & 15.7 & 0 & 15.3 & 0 & 15.4 & 0 & 14.4 & 0 & 19 & 0 & 15.8 & 0 & 15.8 & 0 \\
\hline Carbon Dioxide ${ }^{b}$ & $\mathrm{mg} / \mathrm{L}$ & NR & - & 50 & 0 & 25 & 0 & NR & - & 35 & 0 & 20 & 0 & 30 & 0 & 30 & 0 \\
\hline Alkalinity $^{\mathrm{b}}$ & $\mathrm{mg} / \mathrm{L}$ & 310 & 0 & 360 & 0 & 370 & 0 & 360 & 0 & 320 & 0 & 330 & 0 & 350 & 0 & 390 & 0 \\
\hline Chloride $^{b}$ & $\mathrm{mg} / \mathrm{L}$ & 11 & 0 & 8.2 & 0 & 22 & 0 & 11 & 0 & 5.2 & 0 & 8.4 & 0 & 5.9 & 0 & 34 & 2 \\
\hline Dissolved Hydrogen & $\mathrm{nM}$ & $N A^{d}$ & - & $3.1^{\mathrm{e}}$ & 3 & NA & - & NA & - & NA & - & NA & - & NA & - & NA & - \\
\hline Chloroform & $\mu \mathrm{g} / \mathrm{L}$ & $<1$ & 0 & 14 & 2 & $<1$ & 0 & $<1$ & 0 & $<1$ & 0 & $<1$ & 0 & $<1$ & 0 & $<1$ & 0 \\
\hline \multirow{3}{*}{$\begin{array}{l}\text { Dichloromethane } \\
\text { (methylene chloride) }\end{array}$} & & & & & & & & & & & & & & & & & 0 \\
\hline & $\mu g / L$ & $<1$ & 0 & $<1$ & 0 & $<1$ & 0 & $<1$ & 0 & $<1$ & 0 & $<1$ & 0 & $<1$ & 0 & $<1$ & 0 \\
\hline & \multicolumn{2}{|c|}{ Total points => } & 4 & & 7 & & -1 & & -1 & & 2 & & 8 & & 2 & & 4 \\
\hline
\end{tabular}


TABLE 1.3 (Cont.)

\begin{tabular}{|c|c|c|c|c|c|c|c|c|c|c|c|c|c|c|c|c|c|}
\hline \multirow[b]{2}{*}{ Constituent } & \multirow[b]{2}{*}{ Units } & \multicolumn{2}{|c|}{ MW09 } & \multicolumn{2}{|c|}{ MW10 } & \multicolumn{2}{|c|}{ SB01 } & \multicolumn{2}{|c|}{$\mathrm{SB} 04$} & \multicolumn{2}{|c|}{ SB05 } & \multicolumn{2}{|c|}{ SB07R } & \multicolumn{2}{|c|}{ SB08 } & \multicolumn{2}{|c|}{ SB09 } \\
\hline & & Conc. & Points & Conc. & Points & Conc. & Points & Conc. & Points & Conc. & Points & Conc. & Points & Conc. & Points & Conc. & Points \\
\hline Dissolved Oxygen & $\mathrm{mg} / \mathrm{L}$ & 4.1 & 0 & 5.09 & -3 & 3.81 & 0 & 6.18 & -3 & 2.58 & 0 & 5.08 & -3 & 3.57 & 0 & 0.89 & 3 \\
\hline Nitrate & $\mathrm{mg} / \mathrm{L}$ & 3.8 & 0 & 1.1 & 0 & 0.8 & 2 & 4.6 & 0 & 2.1 & 0 & 1.1 & 0 & 0.68 & 2 & 1.2 & 0 \\
\hline Iron(II) & $\mathrm{mg} / \mathrm{L}$ & 0.69 & 0 & 0 & 0 & 0.23 & 0 & 0.23 & 0 & 0.07 & 0 & 0.07 & 0 & 0.24 & 0 & 0.09 & 0 \\
\hline Sulfate & $\mathrm{mg} / \mathrm{L}$ & 6.4 & 2 & 9.1 & 2 & 7.4 & 2 & 15 & 2 & 4.9 & 2 & 11 & 2 & 7.4 & 2 & 32 & 0 \\
\hline Sulfide & $\mathrm{mg} / \mathrm{L}$ & $<0.02$ & 0 & $<0.02$ & 0 & $<0.02$ & 0 & $<0.02$ & 0 & $<0.02$ & 0 & $<0.02$ & 0 & $<0.02$ & 0 & $<0.02$ & 0 \\
\hline Methane & $\mathrm{mg} / \mathrm{L}$ & $<0.002$ & 0 & $<0.002$ & 0 & $<0.002$ & 0 & $<0.002$ & 0 & $<0.002$ & 0 & $<0.002$ & 0 & $<0.002$ & 0 & $<0.002$ & 0 \\
\hline ORP & $\mathrm{mV}$ & 152 & 0 & 270 & 0 & 173 & 0 & 266 & 0 & 296 & 0 & 237 & 0 & 208 & 0 & 236 & 0 \\
\hline $\mathrm{pH}$ & - & 6.35 & 0 & 6.36 & 0 & 6.37 & 0 & 6.45 & 0 & 4.03 & -2 & 6.38 & 0 & 6.53 & 0 & 6.32 & 0 \\
\hline Total Organic Carbon & $\mathrm{mg} / \mathrm{L}$ & $<1$ & 0 & 1.2 & 0 & $<1$ & 0 & 2 & 0 & 1.2 & 0 & 1.1 & 0 & $<1$ & 0 & 1.5 & 0 \\
\hline Temperature & ${ }^{\circ} \mathrm{C}$ & 14.9 & 0 & 17 & 0 & 18 & 0 & 16.2 & 0 & 16.7 & 0 & 19 & 0 & 15.8 & 0 & 14.3 & 0 \\
\hline Carbon Dioxide ${ }^{b}$ & $\mathrm{mg} / \mathrm{L}$ & 30 & 0 & 35 & 0 & 25 & 0 & NR & - & 35 & 0 & 40 & 0 & 35 & 0 & 40 & 0 \\
\hline Alkalinity $^{\mathrm{b}}$ & $\mathrm{mg} / \mathrm{L}$ & 360 & 0 & 330 & 0 & 340 & 0 & 370 & 0 & 320 & 0 & 310 & 0 & 330 & 0 & 530 & 0 \\
\hline Chloride $^{b}$ & $\mathrm{mg} / \mathrm{L}$ & 6.9 & 0 & 100 & 2 & 30 & 2 & 48 & 2 & 66 & 2 & 23 & 2 & 17 & 0 & 16 & 0 \\
\hline Dissolved Hydrogen & $\mathrm{nM}$ & NA & - & NA & - & $71^{\mathrm{e}}$ & 3 & $24^{e}$ & 3 & $11^{\mathrm{e}}$ & 3 & NA & - & $6.1^{\mathrm{e}}$ & 3 & NA & - \\
\hline Chloroform & $\mu g / L$ & $<1$ & 0 & $<1$ & 0 & 4.9 & 2 & $0.5 \mathrm{Jt}^{\mathrm{f}}$ & 2 & 12 & 2 & 1.7 & 2 & 2 & 2 & $<1$ & 0 \\
\hline \multirow{3}{*}{$\begin{array}{l}\text { Dichloromethane } \\
\text { (methylene chloride) }\end{array}$} & & & & & & & & & & & & & & & & & \\
\hline & $\mu \mathrm{g} / \mathrm{L}$ & $<1$ & 0 & $<1$ & 0 & $<1$ & 0 & $<1$ & 0 & $<1$ & 0 & $<1$ & 0 & $<1$ & 0 & $<1$ & 0 \\
\hline & \multicolumn{2}{|c|}{ Total points $=>$} & 2 & & 1 & & 11 & & 6 & & 7 & & 3 & & 9 & & 3 \\
\hline
\end{tabular}

a Scoring is based on results for samples collected in March 2007. Points are interpreted as follows (EPA 1998):

Scoring is based on results for samples collected in March
$0-5$
$6-14$ Inadequate evidence for reductive dechlorination.

15-20 Adequate evidence for reductive dechlorination.

Strong evidence for reductive dechlorination.

${ }^{6}$ For evaluation of alkalinity, carbon dioxide, and chloride, MW01 (because of its location) was selected to represent background levels. For these constituents, points are awarded when the concentration is greater than twice the background concentration.

${ }^{c} \mathrm{NR}$, not recorded.

${ }^{d}$ NA, not analyzed for dissolved hydrogen in March 2007.

e Dissolved hydrogen result from September 2005 sampling.

${ }^{f}$ Qualifier $\mathrm{J}$ indicates an estimated concentration below the method quantitation limit of $1.0 \mu \mathrm{gg} / \mathrm{L}$. 


\subsection{Summary}

The results of site characterization and monitoring at the former CCC/USDA facility support the conclusion that MNA, by itself, does not represent the most viable remedial alternative for restoration of the groundwater at Centralia. Although limited evidence has been found that the natural site conditions might promote natural in situ reductive dechlorination of carbon tetrachloride at some locations, the effectiveness and areal extent of these processes, as documented to date, have proven insufficient to effectively mitigate the contaminant levels.

The identified groundwater contamination currently poses no unacceptable health risks, in the absence of identified potential human receptors in the vicinity of the former CCC/USDA facility. Carbon tetrachloride contamination identified in subsurface soils at SB12 is at concentrations on the order of the Kansas Tier 2 RBSL of $200 \mu \mathrm{g} / \mathrm{kg}$ for the soil-to-groundwater protection pathway. 


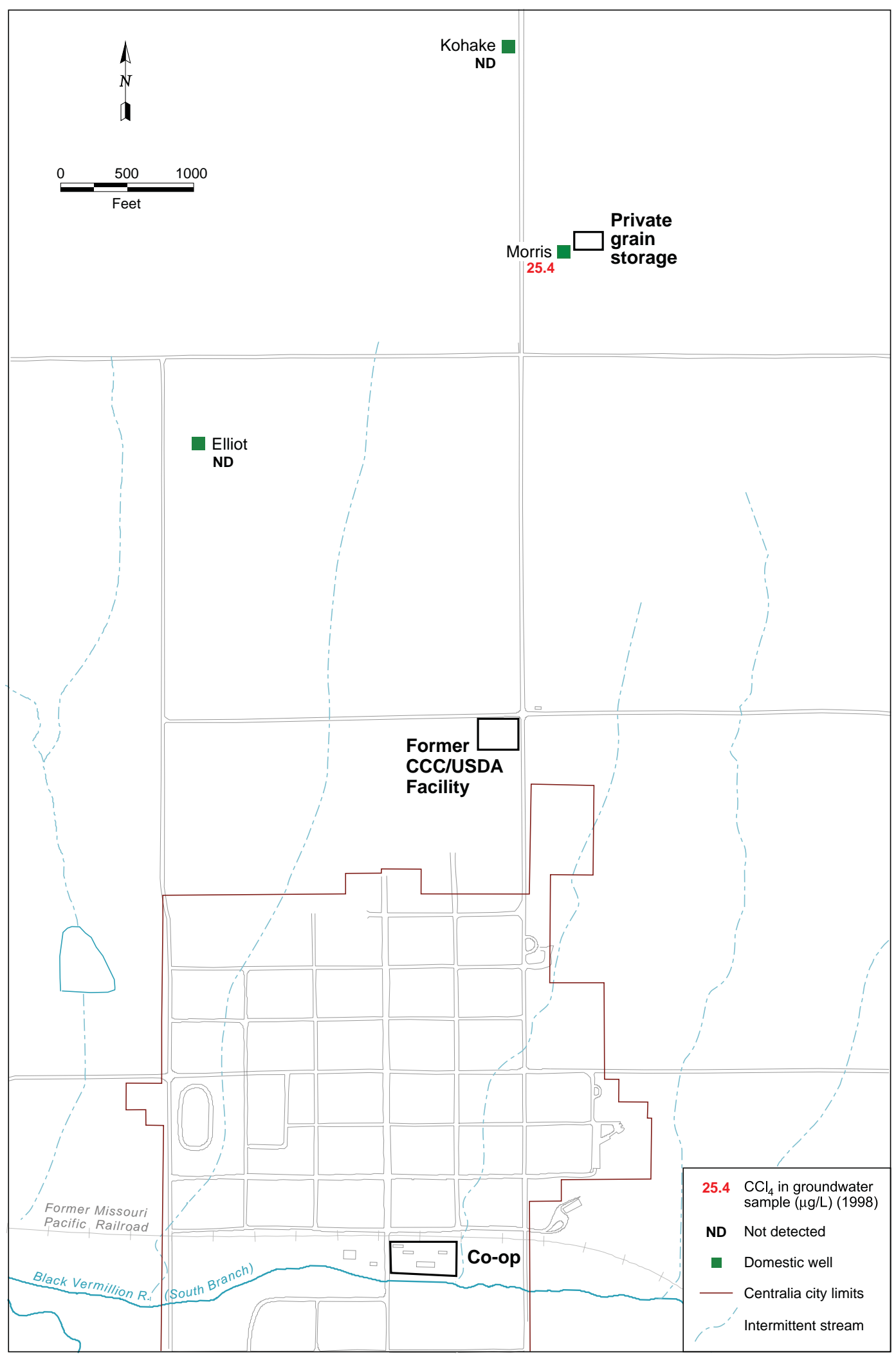

FIGURE 1.1 Locations of the former CCC/USDA facility and the contaminated private well at Centralia. 


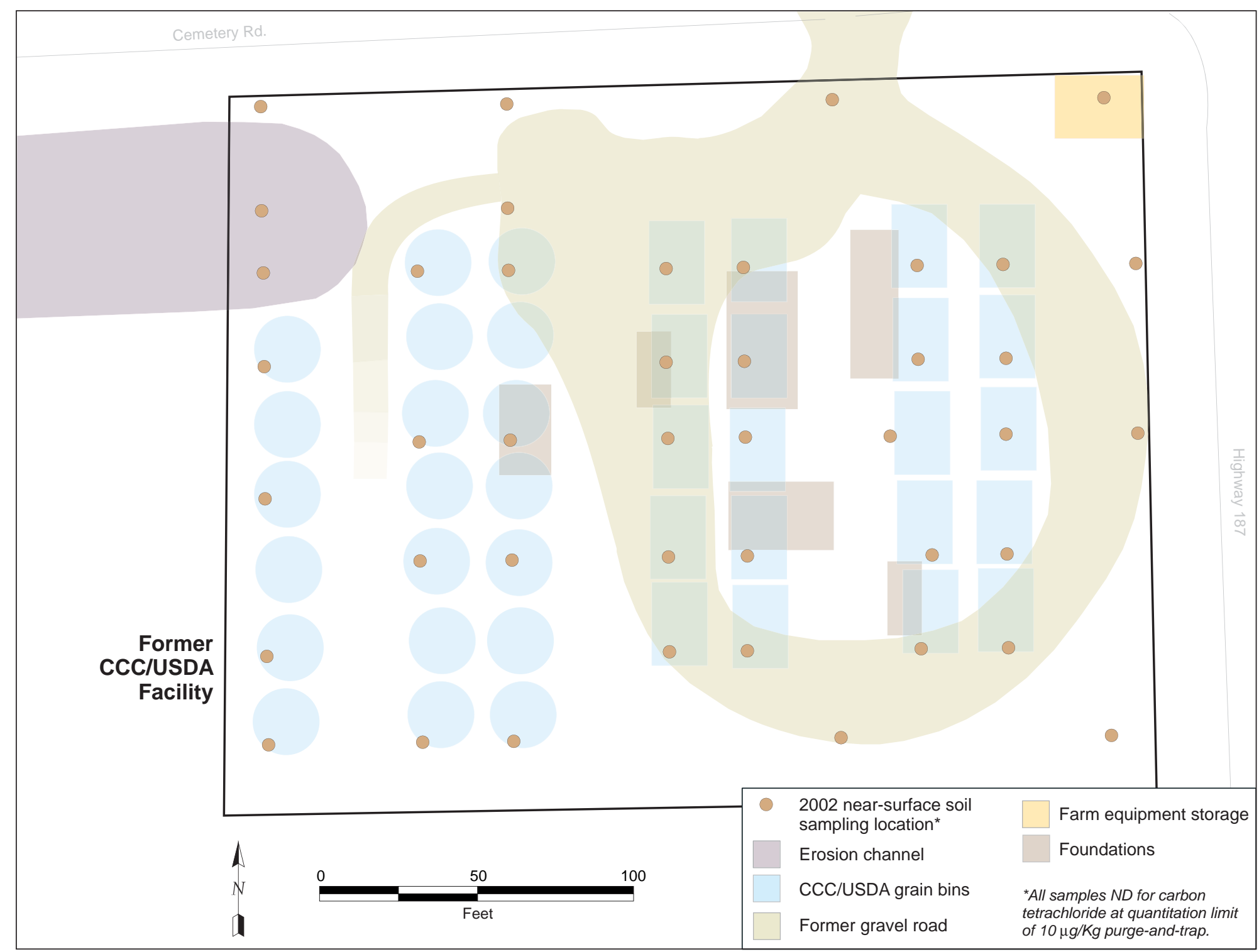

FIGURE 1.2 Locations of near-surface soil sampling in 2002. No carbon tetrachloride was detected. 


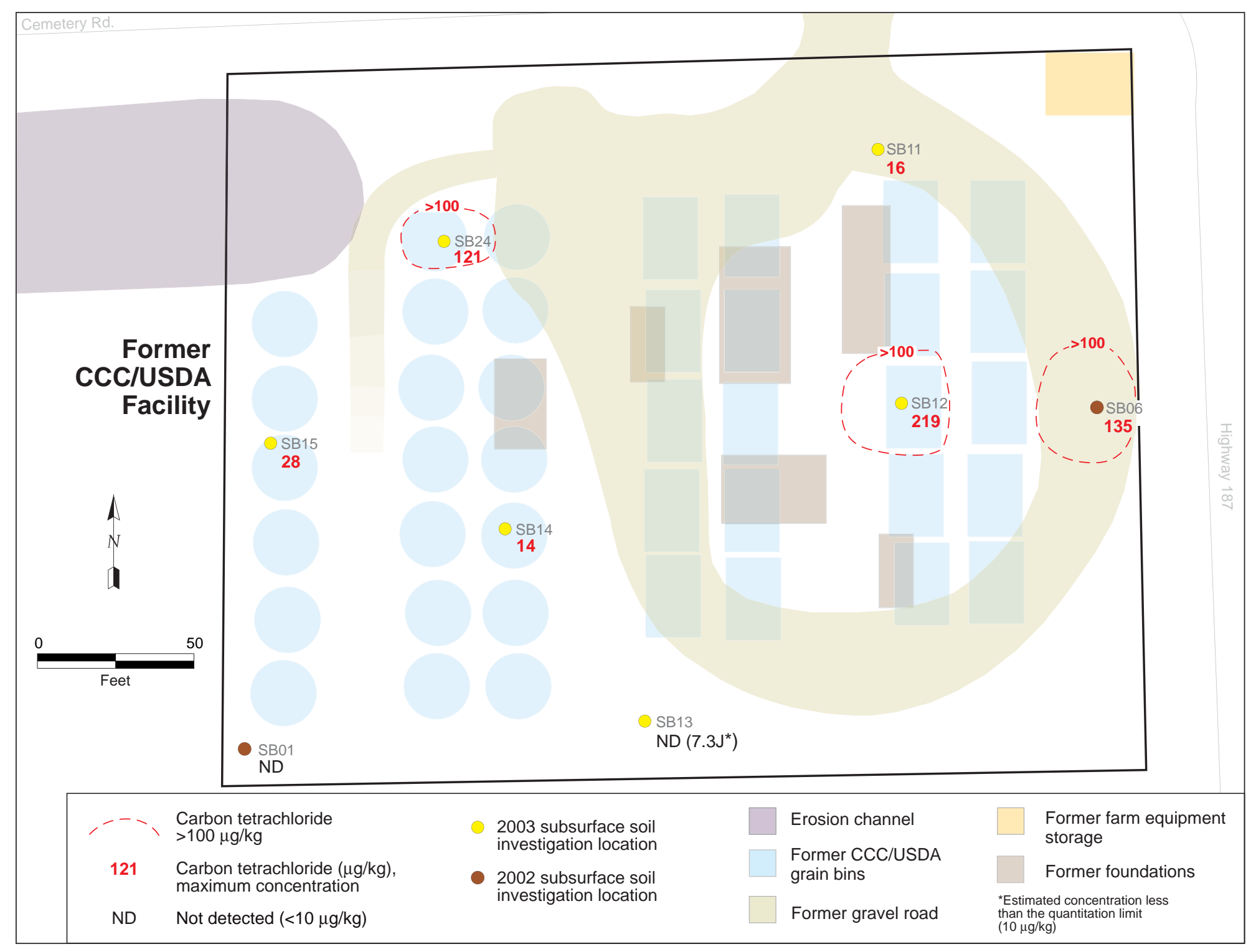

FIGURE 1.3 Locations and results of vertical-profile soil sampling in 2002 and 2003. 


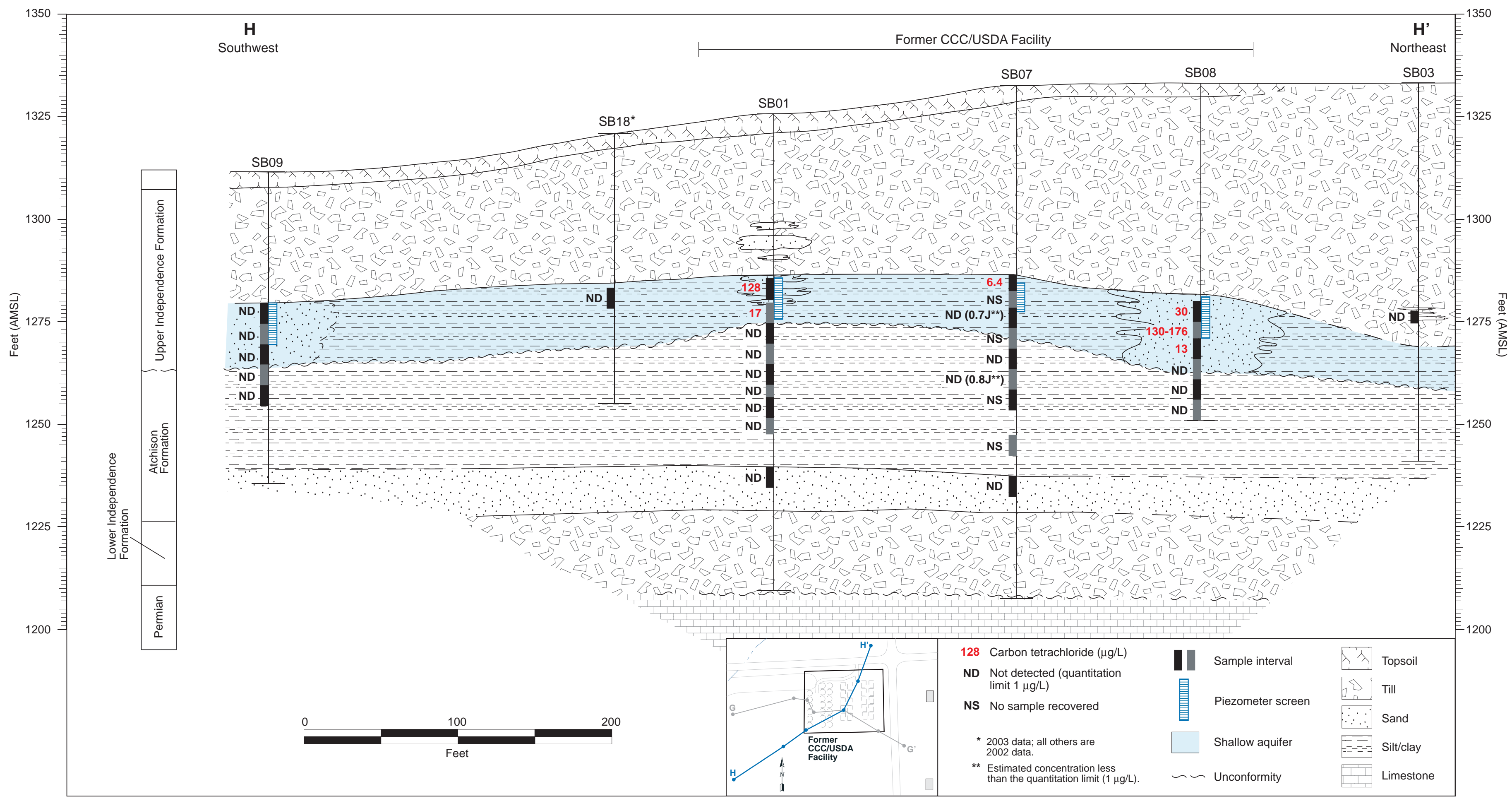

FIGURE 1.4 Southwest-northeast hydrogeologic cross section at Centralia (vertically exaggerated), with results for carbon tetrachloride in vertical-profile groundwater samples collected in 2002 and 2003. 


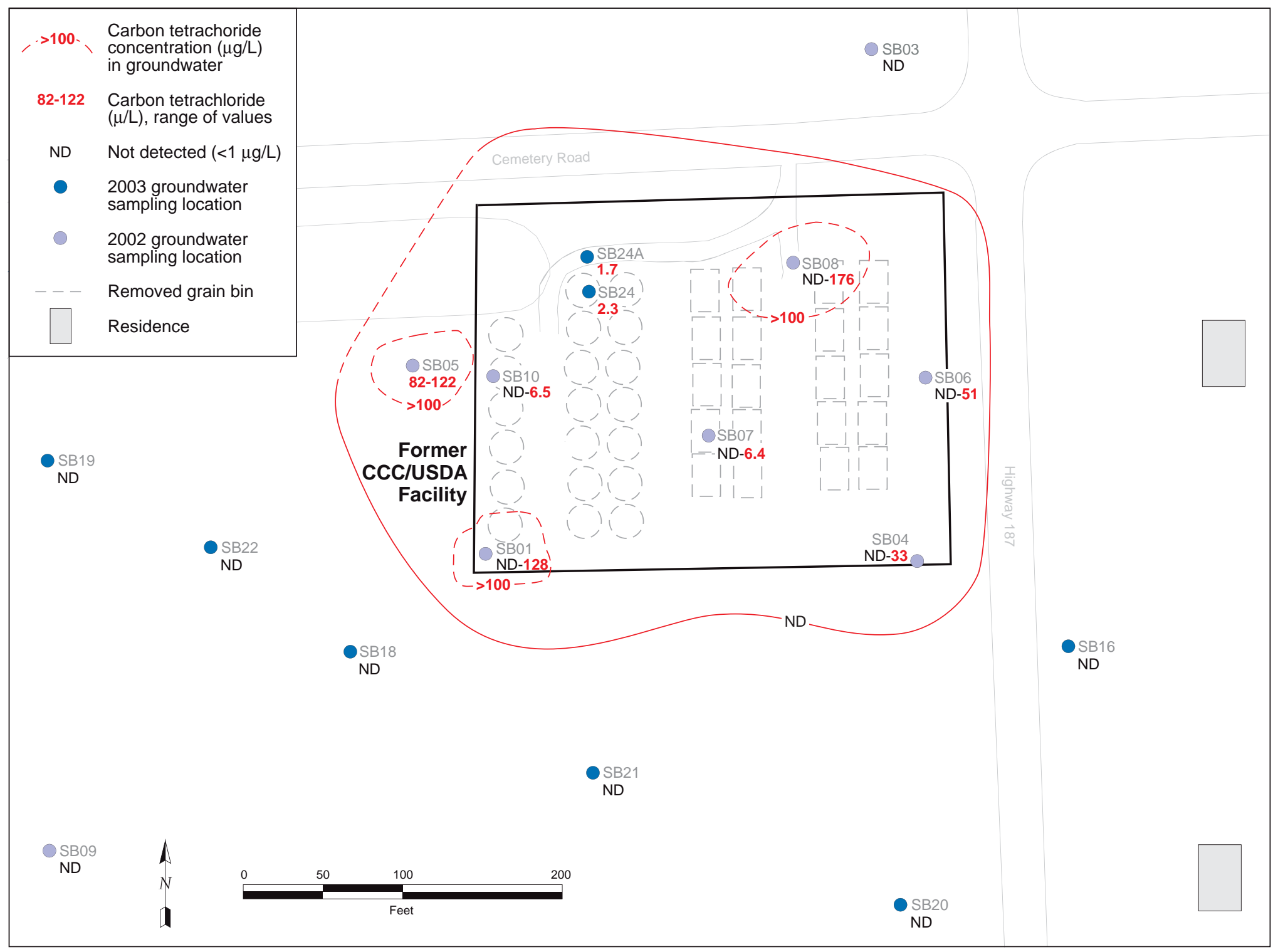

FIGURE 1.5 Lateral distribution of carbon tetrachloride in the shallow aquifer at Centralia, as interpreted from analytical results for 2002 and 2003. 


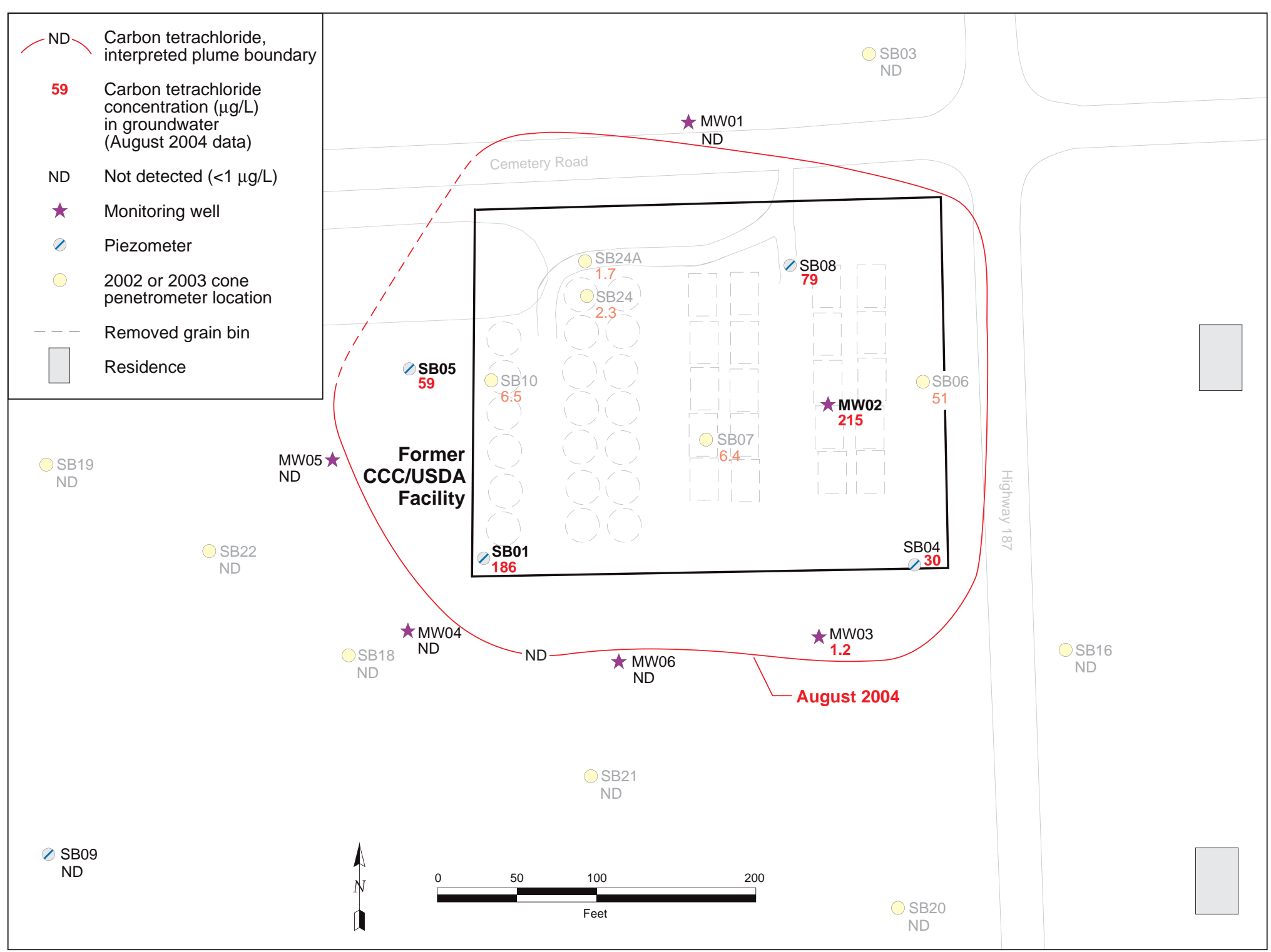

FIGURE 1.6 Monitoring network established in 2004, with the lateral distribution of carbon tetrachloride in the shallow aquifer at Centralia, as interpreted from analytical results for groundwater sampling in August 2004 and earlier. 


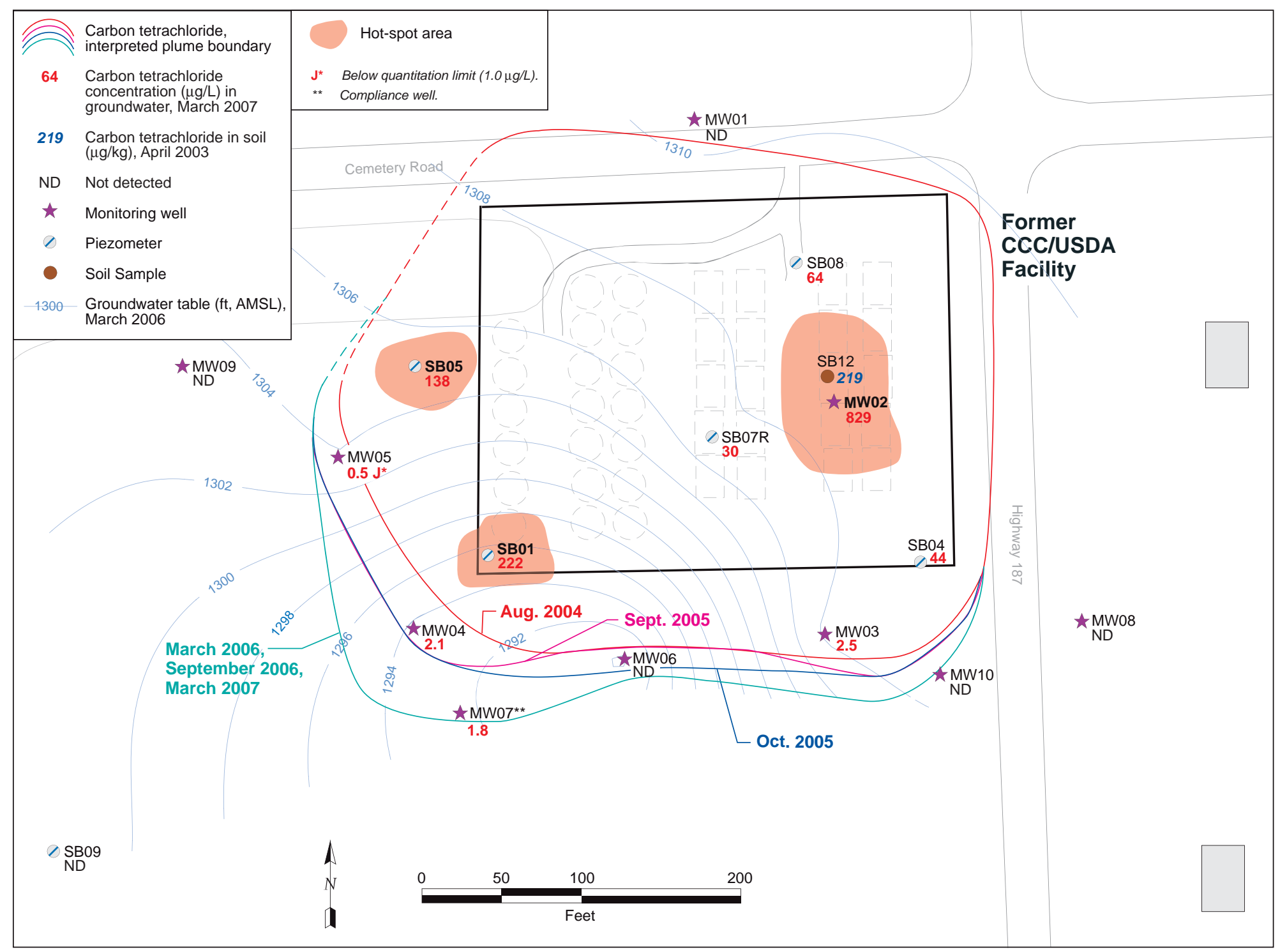

FIGURE 1.7 Analytical results for carbon tetrachloride in groundwater samples collected in March 2007, with interpreted water level contours for March 2006, interpreted plume boundaries in 2004-2007, and analytical results (maximum) for soil samples collected at SB12 in April 2003. 


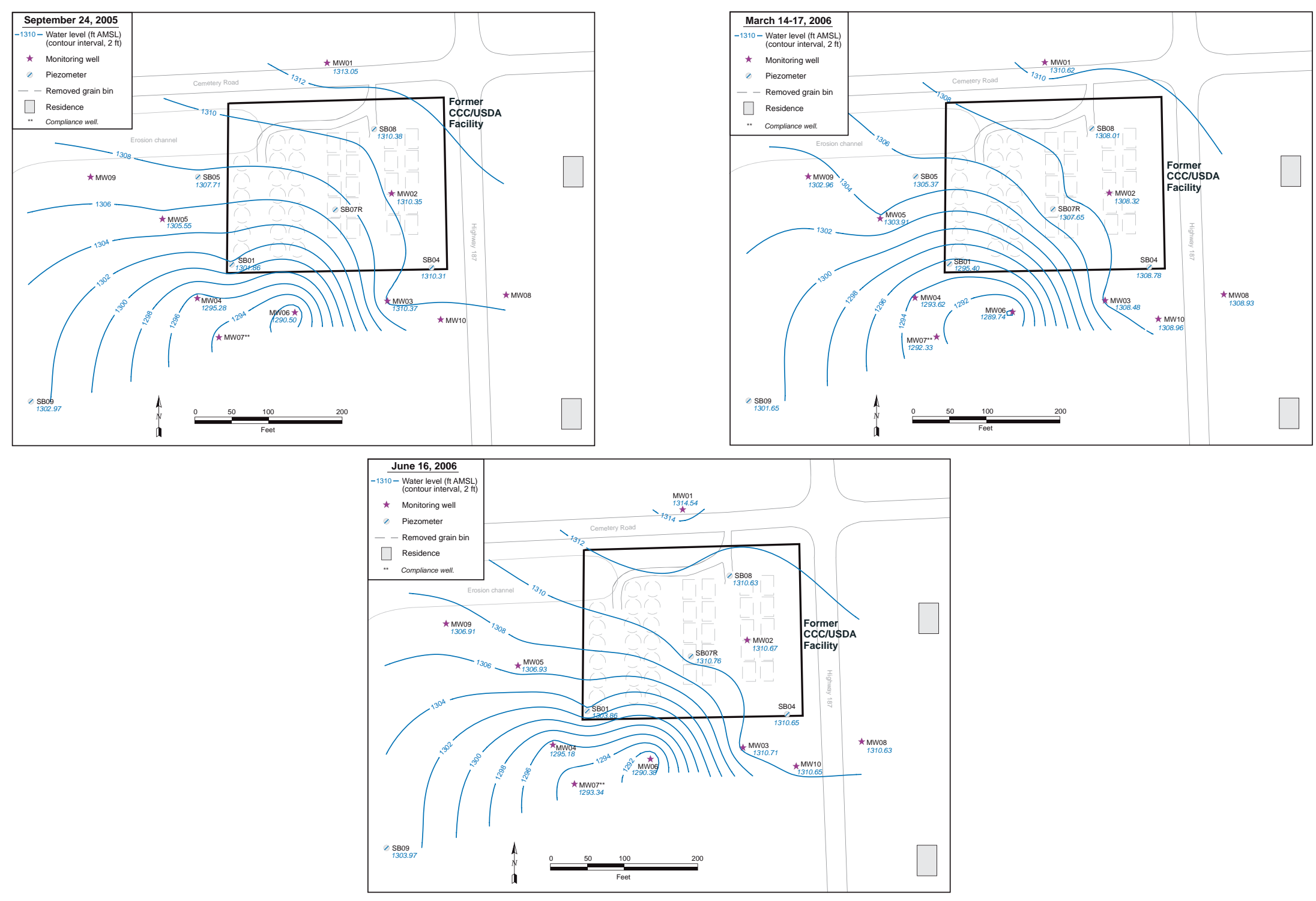

FIGURE 1.8 Water level contours for the shallow aquifer at Centralia on September 24, 2005, March 14-17, 2006, and June 16, 2006, as interpreted from measurements in a monitoring network expanded in January 2006 through the addition of wells MW07-MW10. 


\section{Description of the Recommended Interim Measure}

The CCC/USDA is recommending an initial short-term, field-scale pilot test of a commercially available remedial approach, with subsequent implementation of the approach (if the pilot test is successful) as a non-emergency IM. The purpose is to mitigate existing contaminant levels in soil and groundwater at Centralia and to moderate or decrease the potential future concentrations of carbon tetrachloride in the groundwater. The initial pilot test will address one of three identified hot-spot areas, and the subsequent full implementation will address the other two hot-spot areas.

The EHC material recommended for use in treatment at Centralia is marketed by Adventus Americas, Inc., Freeport, Illinois. The EHC material promotes in situ chemical reduction (ISCR) of carbon tetrachloride. In the proposed application of the ISCR approach, the EHC material, which is a proprietary mixture of food-grade organic carbon and zero-valent iron (ZVI), will be introduced into the subsurface and released slowly into the formation. In the saturated and vadose zones, the EHC material will create highly reducing conditions that will foster both chemical and biological reductive dechlorination of carbon tetrachloride. The estimated effective lifetime of the EHC material following injection, on the basis of applications reported by the manufacturer, is 1-5 yr (Adventus 2006, 2007a-e).

The CCC/USDA recommends the initial pilot testing of the ISCR approach to address the elevated carbon tetrachloride levels identified in the hot-spot area at MW02, as well as the possible continuing soil source identified nearby, at SB12 (Figure 2.1). A three-dimensional grid pattern of direct-push injection points will be used to distribute the EHC material (in slurry or aqueous form) throughout the volume of contaminated aquifer material in this area, as well as in the vadose zone at selected locations. Injection of the EHC material will be conducted by a licensed contractor (to be identified upon approval of this conceptual design by the KDHE), under the supervision of Adventus and Argonne technical personnel.

Argonne will periodically sample a network of temporary and permanent borings to be installed in the injection area. The purpose will be to document (1) the contaminant distribution in the saturated and vadose zones prior to injection, (2) the distribution of the EHC material in these zones immediately following injection and at intervals thereafter, and (3) the changes in contaminant concentrations occurring over time in response to the imposed treatment. The details are discussed in Section 4. 


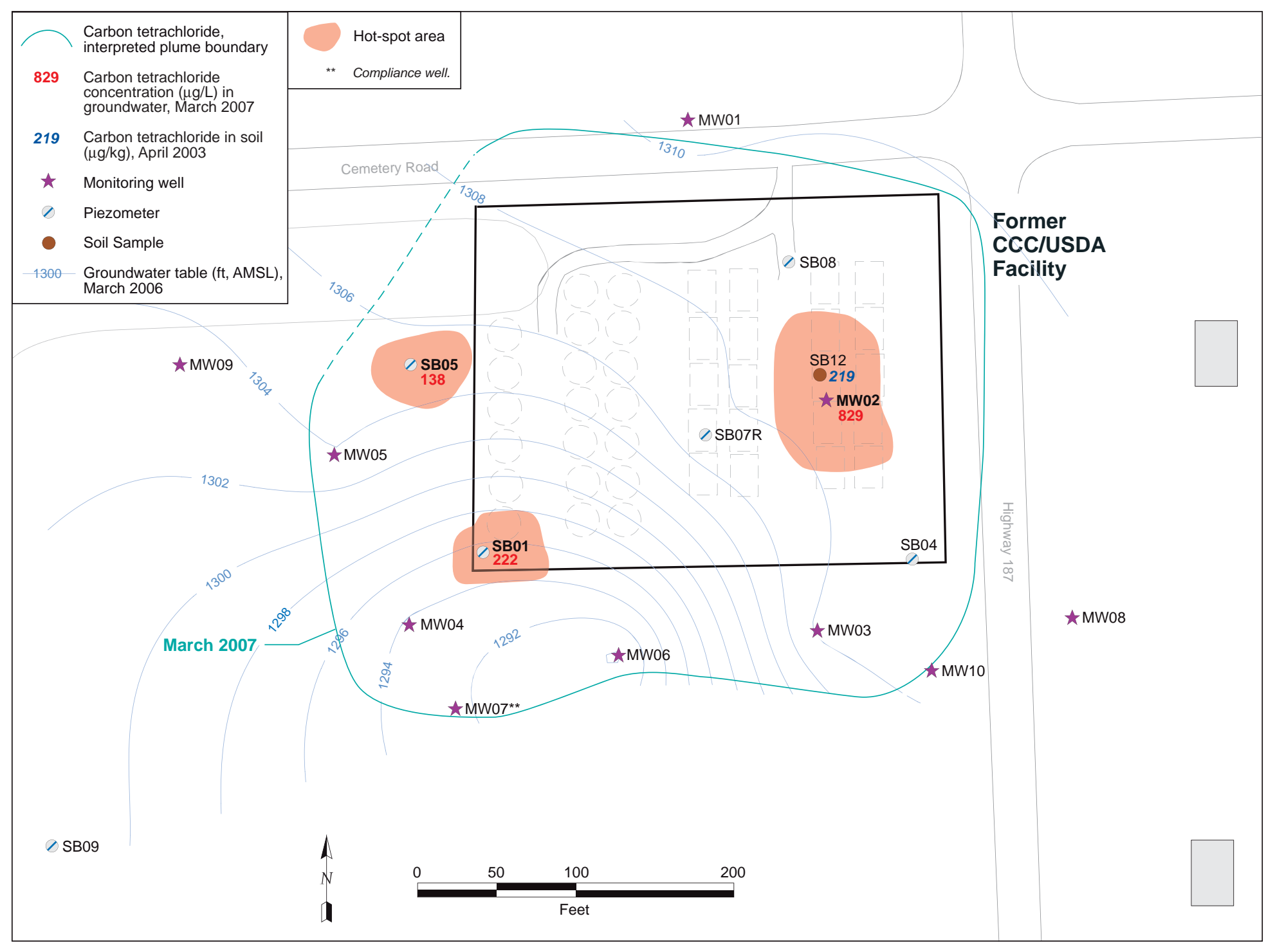

FIGURE 2.1 Analytical results for carbon tetrachloride in groundwater samples collected in the hot-spot areas in March 2007, with interpreted water level contours for March 2006, the interpreted plume boundary in March 2007, and the analytical results (maximum) for carbon tetrachloride in soil at location SB12 in April 2003. 


\section{Interim Remedial Measure Objectives}

The regulatory, technical, and logistic objectives of the proposed non-emergency IM are as follows:

- To reduce the existing concentrations of carbon tetrachloride in groundwater in the three identified hot-spot areas to levels that are acceptable to the KDHE.

- To reduce carbon tetrachloride concentrations in the soils near the location of former soil boring SB12 and existing monitoring well MW02 to levels below the KDHE Tier 2 RBSL $(200 \mu \mathrm{g} / \mathrm{kg})$ for this contaminant.

- To address the above two objectives in a cost- and time-effective manner, by employing an approach that will limit potential disruption of the contaminated private property at Centralia and will limit or eliminate the potential generation, handling, and required disposal of contaminated investigationderived wastes.

- To operationally test and critically evaluate the viability of the ISCR approach, specifically the Adventus EHC material, as a remedial technology for restoration of the subsurface soils and groundwater at Centralia, as well as potentially at other former CCC/USDA investigation sites in Kansas that might have similar hydrogeologic characteristics, geochemical features, and remedial requirements.

- To gain practical technical and logistic experience in implementation of the ISCR approach and thus facilitate the development of optimal methods and techniques for the potential application of this approach at Centralia and other CCC/USDA investigation sites where the approach might be applicable. 


\section{Interim Measure Design}

Argonne's investigations have shown that the lithologic properties of the unit hosting the contaminated aquifer at Centralia vary both vertically and laterally, resulting in a heterogeneous permeability distribution and relatively restricted groundwater movement across much of the site. An initial short-term, field-scale pilot test is recommended at the most contaminated of the three identified hot-spot areas, near MW02 (Figure 2.1). The pilot test will (1) determine the operational techniques required for optimal implementation and monitoring of the ISCR approach and (2) verify the suitability of this approach for treatment of the carbon tetrachloride contamination at the Centralia site.

The design basis, design specifications, and proposed monitoring activities are outlined below. Estimated costs and a working schedule for implementation of the recommended pilot study will be submitted in an engineering design document upon KDHE approval for use of the ISCR approach at Centralia.

The results of monitoring in the pilot test area over a recommended period of three months following injection of the EHC material will be presented for review by the CCC/USDA and KDHE project managers. If the CCC/USDA and KDHE concur that the ISCR approach has met the objectives specified in Section 3 for the pilot test, the CCC/USDA will request KDHE authorization for the use of this approach in the other two identified hot-spot areas (near SB01 and SB05).

Detailed design and scheduling information for full implementation of the IM near SB01 and SB05 will be developed when the results for the pilot study near MW02 become available. Upon KDHE authorization for use of the ISCR approach as the IM remedy at Centralia, the detailed information will be incorporated into the engineering design for the full implementation. The engineering design will then be submitted for KDHE review and approval.

\subsection{Design Basis}

Although ISCR is considered a new, emerging remedial approach, the Adventus EHC product has been demonstrated to be effective in the treatment of carbon tetrachloride contamination in groundwater (Adventus 2007a-c) and has been employed at a carbon 
tetrachloride contamination site elsewhere in Kansas (Cargill Flour Mill and Elevator, Wellington, Kansas; Adventus 2007d) with the approval of the KDHE (2007b).

At the request of the CCC/USDA, Argonne conducted preliminary bench-scale treatability tests of the Adventus EHC and EHC-M remediation products, in conjunction with pure laboratory reagents and also with soil and groundwater samples obtained from the Centralia area, to which known quantities of carbon tetrachloride had been added. (EHC-M is a variant of the EHC material that is specially formulated for the treatment of heavy metals. Though the potential use of EHC-M is not warranted at the Centralia site, the material was included in Argonne's preliminary batch testing for comparison with the standard EHC product.) The results of these preliminary experiments are in Appendix B. In the presence of either Adventus product, the laboratory batch tests demonstrated a reduction of more than $90 \%$ in the concentration of carbon tetrachloride in the Centralia samples with the compound added in known quantities.

The EHC products are designed to promote the degradation of carbon tetrachloride (and other chlorinated hydrocarbons) through the combined action of both direct inorganic processes and biologically mediated processes, under highly reducing conditions (with very low oxidationreduction potential [ORP]). The organic component of the EHC material is hydrophilic and rich in nutrients. In combination with a high surface area, these properties promote the growth of bacteria in the subsurface. As the bacteria grow, indigenous heterotrophic species deplete the available dissolved oxygen, thereby reducing the local ORP. As the bacteria grow, they also ferment carbon and release volatile fatty acids that diffuse from the fermentation site into the contaminated aquifer and provide electron donors for other bacteria, including dehalogenators and halorespiring species. The small ZVI particles in the EHC material provide a large reactive surface area, which promotes abiotic dechlorination and causes a further drop in ORP in the formation due to chemical oxygen scavenging.

Adventus (2007b) reports that ORP values as low as $-550 \mathrm{mV}$ can be achieved in the contaminated formation after the injection of EHC material. Under these conditions, many normally recalcitrant organic compounds (including carbon tetrachloride) can become thermodynamically unstable and be degraded via pathways that produce few, if any, undesirable intermediate degradation products.

The investigations conducted by Argonne on behalf of the CCC/USDA have demonstrated that the natural conditions in the shallow aquifer at Centralia are, at least locally, 
conducive to the reductive dechlorination of carbon tetrachloride. The proposed ISCR treatment approach is therefore expected to enhance the degradative processes that are already occurring (to a limited degree) at this site. Argonne's studies have also shown that the rates of groundwater and contaminant migration in the aquifer are relatively slow. Hence, substantial residence time is expected for the contaminants and the injected amendments in the aquifer volumes targeted at MW02 for treatment during the pilot test, as well as in the hot-spot areas at SB01 and SB05 identified for full implementation of this IM.

\subsection{Design Specifications}

The design of the proposed Centralia pilot test program summarized below was developed as a collaborative effort involving scientific and technical staff of the CCC/USDA; Argonne; Adventus Americas, Inc.; and prospective implementation contractors. The design is based on the analytical data and the geologic, hydrogeologic, and geochemical interpretations summarized in this document. The design is intended to meet the program objectives identified in Section 3.

\subsubsection{Pilot Test Treatment Area}

The area selected for the short-term field-scale pilot test is approximately centered on the locations of existing monitoring well MW02 and former investigative boring SB12 (Figure 4.1) These two borings penetrated the highest concentrations of carbon tetrachloride identified in both vadose zone soils and groundwater at the Centralia investigation site. The two borings define a hot-spot area that has demonstrated sustained high levels of the contaminant. The pilot test activities will be confined to a rectangular area around MW02 and SB12. The surface of the rectangular area will measure approximately $45 \mathrm{ft}$ wide by $75 \mathrm{ft}$ long, oriented approximately orthogonally to the apparent direction of groundwater flow in this portion of the site. The targeted area is currently privately owned, uncultivated pastureland. The CCC/USDA has obtained access to this property for sampling in the past and foresees no problems in obtaining access for the proposed pilot study. 


\subsubsection{Strategy for Injection of the ISCR Amendments}

\subsubsection{Distribution of Injection Points and Injection Operations}

An arrangement of 15 temporary injection points in a grid pattern is proposed (Figure 4.2) for emplacement of the ISCR amendments (EHC material). The injection points will be arranged initially in a uniform spacing of $15 \mathrm{ft}$, yielding an anticipated injection radius of influence of $7.5 \mathrm{ft}$ per injection point. The recommended spacing is based on experience of Adventus personnel and the prospective contractors with injection of the EHC material at other investigation sites having roughly comparable subsurface characteristics. As the injection of EHC material progresses at Centralia, this spacing might be modified, if necessary (subject to the approval of the CCC/USDA and KDHE project managers), to ensure that an adequate distribution of material in the targeted testing volume is achieved.

The contractor will accomplish the injection by using direct-push equipment (Geoprobe or equivalent) that has been specially modified by the contractor to permit the emplacement of EHC material over carefully controlled depths in the subsurface. Injection of the EHC material will be performed over successive depth intervals at each boring location. The exact depth intervals will be determined in consultation with Adventus and contractor personnel and with the $\mathrm{CCC} / \mathrm{USDA}$ and KDHE project managers. Injection into the saturated zone is proposed over an approximate depth interval of $20 \mathrm{ft}$ at each injection point, from $40 \mathrm{ft}$ to $60 \mathrm{ft}$ below ground level (BGL). Because carbon tetrachloride contamination of vadose zone soils was previously identified only at the SB12 investigative boring location, EHC injection into the vadose zone is recommend at the ten injection points closest to this location. At these points, injection into the vadose zone soils will extend over the 20 - $\mathrm{ft}$ depth interval from $20 \mathrm{ft}$ to $40 \mathrm{ft}$ BGL.

Additional descriptions of the equipment and details of the procedures to be used during injection of the EHC material will be provided in the engineering design for the pilot test, along with a detailed heath and safety plan for the injection component of the pilot test. The health and safety plan (to be submitted by the contractor) will meet Argonne standards and will be approved by Argonne. 


\subsubsection{Selection and Preparation of the EHC Material}

The pilot study's targeted volume in the saturated zone (approximately 67,500 $\mathrm{ft}^{3}$ ) will be treated with the standard EHC material (Adventus 2007a,b), which is supplied in a solid, dry powder form. The EHC material will be mixed on-site immediately prior to subsurface emplacement, with uncontaminated (by carbon tetrachloride) water from the Centralia municipal supply system, to form an injection slurry containing approximately $30 \%$ solids by weight. Slurry will be injected uniformly at each location, if possible, to yield an approximate concentration of EHC in the amended groundwater of $0.4 \mathrm{lb} / \mathrm{ft}^{3}$, or $0.1 \%$ (mass of EHC to total mass of saturated soil treated).

The pilot test's targeted volume (approximately 18,000 $\mathrm{ft}^{3}$ ) of contaminated vadose zone soil will be treated with an aqueous formulation of EHC, known as EHC-A (Adventus 2006, 2007a,d,e,f). EHC-A is composed of a water-soluble organic amendment and soluble reduced iron $\left(\mathrm{Fe}^{2+}\right)$. The aqueous form of $\mathrm{EHC}$ is recommended for effective distribution of injected material in vadose zone soil of limited permeability. The EHC-A will be injected as a relatively dilute solution (10\% EHC by weight), thus increasing the volume of injection fluid required to achieve a final EHC concentration of $0.1 \%$ (by mass, relative to the total mass of soil) in the treated interval. EHC-A, which (like the standard EHC material) is also supplied as a dry powder, will be mixed on-site immediately prior to subsurface emplacement, with uncontaminated (by carbon tetrachloride) water from the Centralia municipal supply system.

Material safety data sheets for the EHC and EHC-A products are in Appendix C.

\subsubsection{Pilot Test Monitoring Program}

A detailed program of vadose zone soil and groundwater sampling and analyses will be performed by Argonne as part of the Centralia pilot study. The results will permit documentation of the ISCR treatment approach, as well as the operational procedures and techniques used to conduct the pilot investigation. The results will serve as the basis for critical evaluation of the effectiveness of the ISCR approach.

The primary elements of the evaluation program will be as follows: 
- Pre-treatment baseline characterization

- Evaluation of the injection process and the initial distribution of the EHC material

- Post-injection monitoring

The specific activities and analyses to be conducted during each phase of the performance monitoring program are summarized below and in Table 4.1. The locations of the monitoring activities are shown in Figure 4.3.

All of the sample collection, sample analysis, and piezometer installation activities described in this section will be performed in accord with the detailed methodologies and procedures in the KDHE-approved Master Work Plan for environmental investigations in Kansas (Argonne 2002b).

\subsubsection{Pre-treatment Baseline Characterization}

To determine the vertical and areal distribution of carbon tetrachloride contamination in the vadose zone soils and in the saturated zone of the pilot test area prior to the application of the ISCR amendments, the Argonne cone penetrometer (CPT) vehicle will be used for baseline soil and groundwater sampling at the pilot test site before treatment begins (Table 4.1 and Figure 4.3). The activities will be as follows:

- At four locations in the test area, the instrumented electronic CPT cone will be used to acquire continuous geomechanical measurements of tip pressure, sleeve friction, conductivity (if possible), borehole inclination, and tip-vs.sleeve ratio to a depth of approximately $60 \mathrm{ft}$ BGL (the base of the targeted treatment interval). Vertical-profile groundwater samples will then be collected at 4-ft intervals through the saturated portion of the planned treatment zone (approximately 40-60 ft BGL) at each of the four boring locations. 
- At one investigative boring, sited at the approximate location of previous Argonne boring SB12, sediment core samples will be collected at 4-ft intervals through the anticipated vadose zone treatment interval (approximately 20-40 ft BGL).

- The CPT will be used to select zones to be targeted for piezometer installation after injection of the EHC material (Section 4.2.3.2). The targeted intervals will be sampled through the CPT rods by using a temporary casing and screen.

- The investigative borings will be grouted before EHC injection begins.

- Groundwater samples will be collected from existing permanent monitoring points SB04, SB07R, SB08, and MW03 near the pilot test area, as well as from MW02 in the treatment area.

All of the groundwater samples and sediment core samples outlined above will be submitted for laboratory analyses for VOCs. Selected additional parameters for all groundwater samples, potentially including temperature, conductivity, $\mathrm{pH}$, ORP, dissolved oxygen content, and reduced iron $\left(\mathrm{Fe}^{2+}\right)$ content, will be determined in the field in accord with procedures in the Master Work Plan (Argonne 2002b).

\subsubsection{Evaluation of the Injection Process and the Initial EHC Distribution}

To investigate the effectiveness of the EHC injection process and the resulting distribution of EHC material in the vadose zone soils and in the saturated zone, the following sampling and analyses will be performed during and immediately after the subsurface injection is complete (Table 4.1 and Figure 4.3 ):

- Close monitoring of groundwater in MW02 will be conducted during injection through the measurement of the water level, conductivity, and other parameters. 
TABLE 4.1 Summary of proposed monitoring activities for the recommended Interim Measure pilot test at Centralia.

\begin{tabular}{|c|c|c|c|}
\hline Locations (Symbols in Figure 4.3) & Activity (Analyses) & Subsurface Interval Targeted for Investigation & Frequency \\
\hline \multicolumn{4}{|l|}{ Pre-treatment Baseline } \\
\hline \multirow[t]{2}{*}{3 temporary borings (blue $\bigcirc$ ) } & CPT electronics & Surface to $\sim 60 \mathrm{ft} B G L^{b}$ & Once, prior to EHC injection \\
\hline & Vertical-profile groundwater (GW)a sampling (VOCs) & 40-60 ft BGL; sampling at 4-ft intervals & \\
\hline \multirow[t]{3}{*}{1 temporary boring near SB12 (brown/blue $\circ$ ) } & CPT electronics & Surface to $\sim 60 \mathrm{ft} \mathrm{BGL}$ & \\
\hline & Soil coring (VOCs) & 20-40 ft BGL; sampling at 4-ft intervals & \\
\hline & GW sampling (VOCs) & 40-60 ft BGL; sampling at 4-ft intervals & \\
\hline 6 temporary borings $(\Delta)$ & GW sampling $(\mathrm{VOCs}+)^{\mathrm{c}}$ & Saturated zone; screen intervals to be determined & \\
\hline $\begin{array}{l}5 \text { existing monitoring points: SB04, SB07R, SB08, } \\
\text { MW02, MW03 }(\star)\end{array}$ & GW sampling (VOCs +) & Saturated zone & \\
\hline \multicolumn{4}{|l|}{ Evaluation after Injection } \\
\hline 6 new monitoring points $(\Delta)$ & Install piezometers & Saturated zone & $\begin{array}{l}\text { Once, immediately after } \\
\text { EHC injection }\end{array}$ \\
\hline 5 existing and 6 new monitoring points $(\star, \Delta)$ & GW sampling (VOCs +) & Saturated zone & \\
\hline $\begin{array}{l}3 \text { temporary borings at } 3 \mathrm{ft}, 5 \mathrm{ft} \text {, and } 7.5 \mathrm{ft} \text { from one } \\
\text { injection point (locations to be determined) }\end{array}$ & Soil coring (visual inspection and photography) & 20-60 ft BGL, in vadose and saturated zones & \\
\hline
\end{tabular}

\section{Post-Injection Monitoring}

1 temporary boring near SB12 (brown/blue $\mathrm{O})$

\section{a GW, groundwater.}

b BGL, below ground level.

c VOCs, plus selected additional parameters. These potentially include temperature, conductivity, $\mathrm{pH}$, redox potential, dissolved oxygen, and reduced iron (Fe $\left.{ }^{2+}\right)$ content. 
- The CPT will be used to install three permanent, 1-in.-diameter monitoring points (piezometers) in the treatment area. Two will be installed near the center of the planned injection grid. One of these piezometers will be installed approximately $3 \mathrm{ft}$ from a planned injection point. The second of these piezometers will be installed approximately midway between this injection point and the nearest adjacent injection point. The third piezometer will be installed in the southeast part of the treatment grid, approximately $30 \mathrm{ft}$ from the two piezometers near the center of the grid. The depth interval(s) to be screened in these three piezometers will be selected on the basis of the identified aquifer characteristics at these locations, with the approval of the CCC/USDA and KDHE project managers. Groundwater samples will be collected from the completed piezometers after they are developed, in accord with KDHE requirements.

- The CPT will also be used to install three additional permanent, 1-in.-diameter monitoring points (piezometers) in the area adjacent to the pilot test site. One piezometer will be located approximately $20 \mathrm{ft}$ to the northeast and upgradient of the test site; the remaining piezometers will be installed $20-30 \mathrm{ft}$ downgradient to the southwest and southeast, respectively, of the test area. The depth interval(s) to be screened in these piezometers will be selected on the basis of the identified aquifer characteristics at these locations, with the approval of the CCC/USDA and KDHE project managers. (These three installations adjacent to the pilot test site will bring the total number of newly installed piezometers to five.) Groundwater samples will be collected from the completed piezometers after they are developed, in accord with KDHE requirements.

- The field parameters for groundwater identified in Section 4.2.3.1 will be measured in the full network of 11 monitoring points (6 new piezometers and 5 previously existing points). Groundwater samples will be collected for VOCs analyses if the field parameters suggest that chemical conditions in the injection area have changed significantly.

- The CPT will be used to collect continuous sediment core samples, from a depth of $20 \mathrm{ft}$ to $60 \mathrm{ft}$ BGL, in 3 investigative borings located approximately 
$3 \mathrm{ft}, 5 \mathrm{ft}$, and $7.5 \mathrm{ft}$ from 1 of the 15 injection points used to place EHC material in both the vadose zone and the saturated zone in the test area. These locations are not shown in Figure 4.3; they will be identified in consultation with the KDHE and CCC/USDA project managers. The samples will be visually inspected and photographed to determine the radial and stratigraphic distribution of EHC material achieved in relation to the injection point (Adventus 2007a,d). Other tests may be performed in the field to investigate the distribution of EHC material further, on the basis of recommendations from the manufacturer and the results of visual inspection.

- Groundwater levels will be measured in the full network of monitoring points.

\subsubsection{Post-injection Monitoring}

Periodic groundwater sampling and more limited vadose zone soil sampling will be performed after completion of EHC injection, at the intervals specified below. The results will be used to determine the effectiveness and the areal range of influence of the pilot ISCR application. The activities to be performed in this phase of the monitoring program are as follows (Table 4.1 and Figure 4.3):

- During the first month after injection of the EHC material, field parameters for groundwater, including temperature, conductivity, $\mathrm{pH}$, ORP, dissolved oxygen content, and reduced iron (Fe-II) content, will be measured in the field once each week in the network of 7 monitoring points (MW02 and 6 new piezometers) in and near the pilot injection area. Groundwater samples will be collected every two weeks in the network of 7 monitoring points. At the end of the first month, groundwater samples will also be collected from existing monitoring points SB04, SB07R, SB08, and MW03. The samples will be analyzed for VOCs and the additional parameters identified in Section 4.2.3.1.

- During the second and third months after the injection, field parameters for groundwater will be determined in the field every two weeks in the network of 7 monitoring points (MW02 and the 6 new piezometers) in and near the pilot injection area. Groundwater samples will be collected monthly from the 
network of 7 monitoring points in and near the pilot injection area, as well as from existing monitoring points SB04, SB07R, SB08, and MW03. The samples will be analyzed for VOCs and the additional parameters identified in Section 4.2.3.1. The schedule for groundwater sampling in the network of 7 monitoring points in and near the pilot injection area might be adjusted if chemical conditions have changed significantly changed in the injection area, as suggested by field parameters.

- Groundwater sample collection and field parameter measurements in the full network of 11 monitoring points (6 new piezometers and 5 existing points) will be performed once each month during months 4-6 after the injection and quarterly thereafter until the end of the first year.

- At the end of the third month after injection and at the end of the first year, the CPT will be used to collect sediment core samples at 4-ft intervals through the vadose zone treatment interval (approximately 20-40 ft BGL) at the approximate location of previous Argonne boring SB12. The core samples will be analyzed for VOCs.

- Groundwater levels will be measured in the full network of monitoring points at the time of each sampling event noted above.

- Continued monitoring requirements after one year of the observation outlined above will be determined in consultation with the CCC/USDA and KDHE project managers.

\subsubsection{Performance Evaluation of the ISCR Remedial Approach}

The results of all sampling and monitoring activities performed under the monitoring program described in Section 4.2.3 will be compiled and presented to the CCC/USDA and the KDHE project managers for critical review following (1) the first 3 months (approximately 90 days) after injection of the EHC material and (2) at the end of 6 months after the EHC injection. If the CCC/USDA and the KDHE concur that the ISCR approach is effective in reducing the carbon tetrachloride concentrations in the targeted treatment area to acceptable 
levels, the CCC/USDA will request KDHE approval for implementation of this technology at the two remaining hot-spot areas targeted under this IM. If approval is received, the CCC/USDA and Argonne will submit a supplementary engineering design outlining the specifications to be used for the treatment and monitoring of the additional hot-spot areas.

\subsection{Cost Estimate}

The cost estimate will be included in the pilot study engineering design when the ISCR approach has been accepted. The cost estimate will include the following components:

- Adventus and installation contractor costs

- Argonne monitoring point placement costs

- Argonne professional management effort costs

- Laboratory analysis costs

\subsection{Proposed Schedule}

The proposed schedule for the pilot test will be included in the engineering design when the approach has been accepted.

Full implementation will follow upon evaluation by the CCC/USDA and KDHE project managers of the success of the pilot test. 


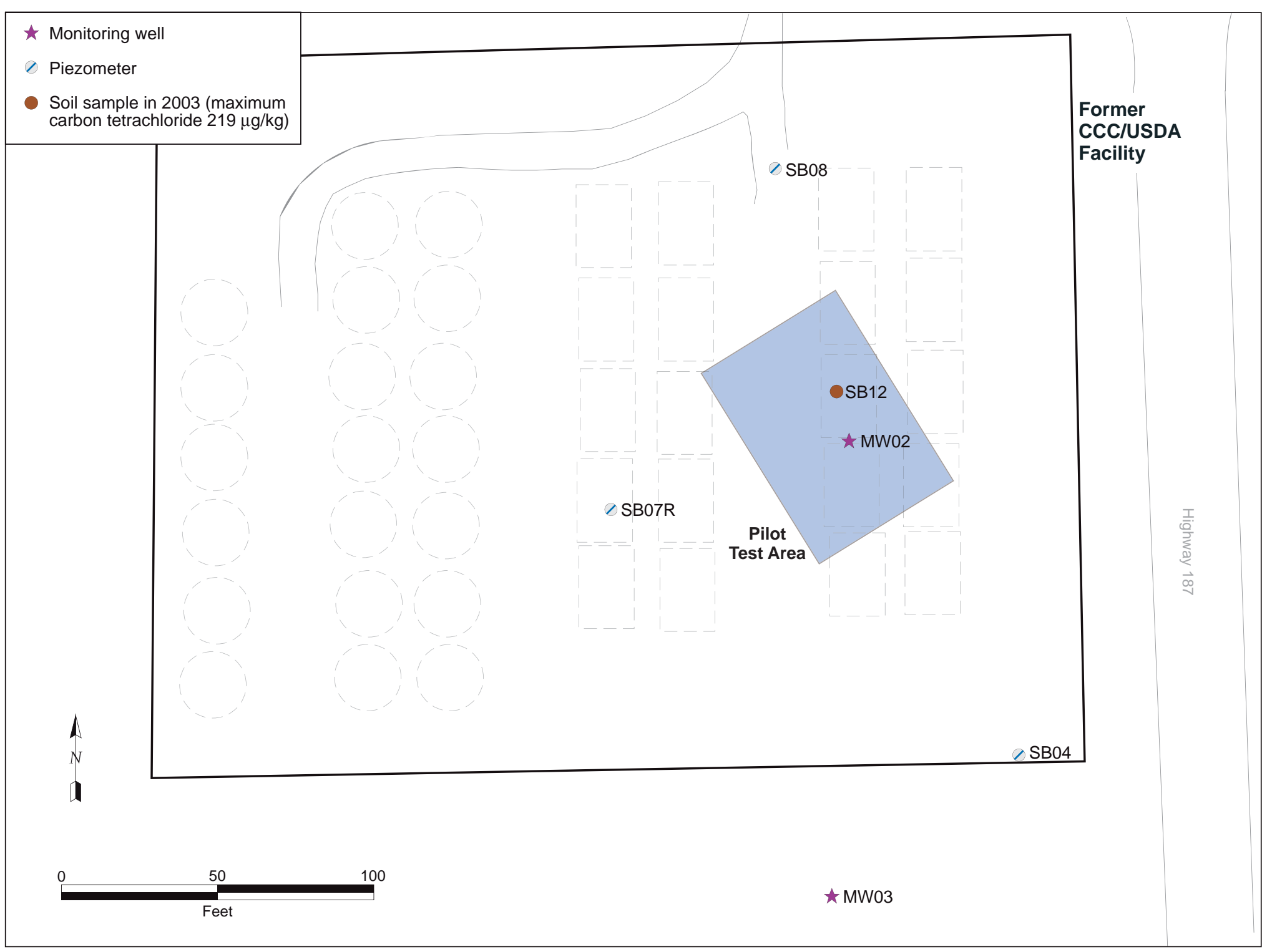

FIGURE 4.1 Proposed pilot test area at Centralia (45 ft x $75 \mathrm{ft}$ ), with locations of soil boring SB12 and MW02 (which define the hot-spot area to be treated in the pilot test) and nearby existing monitoring points. 


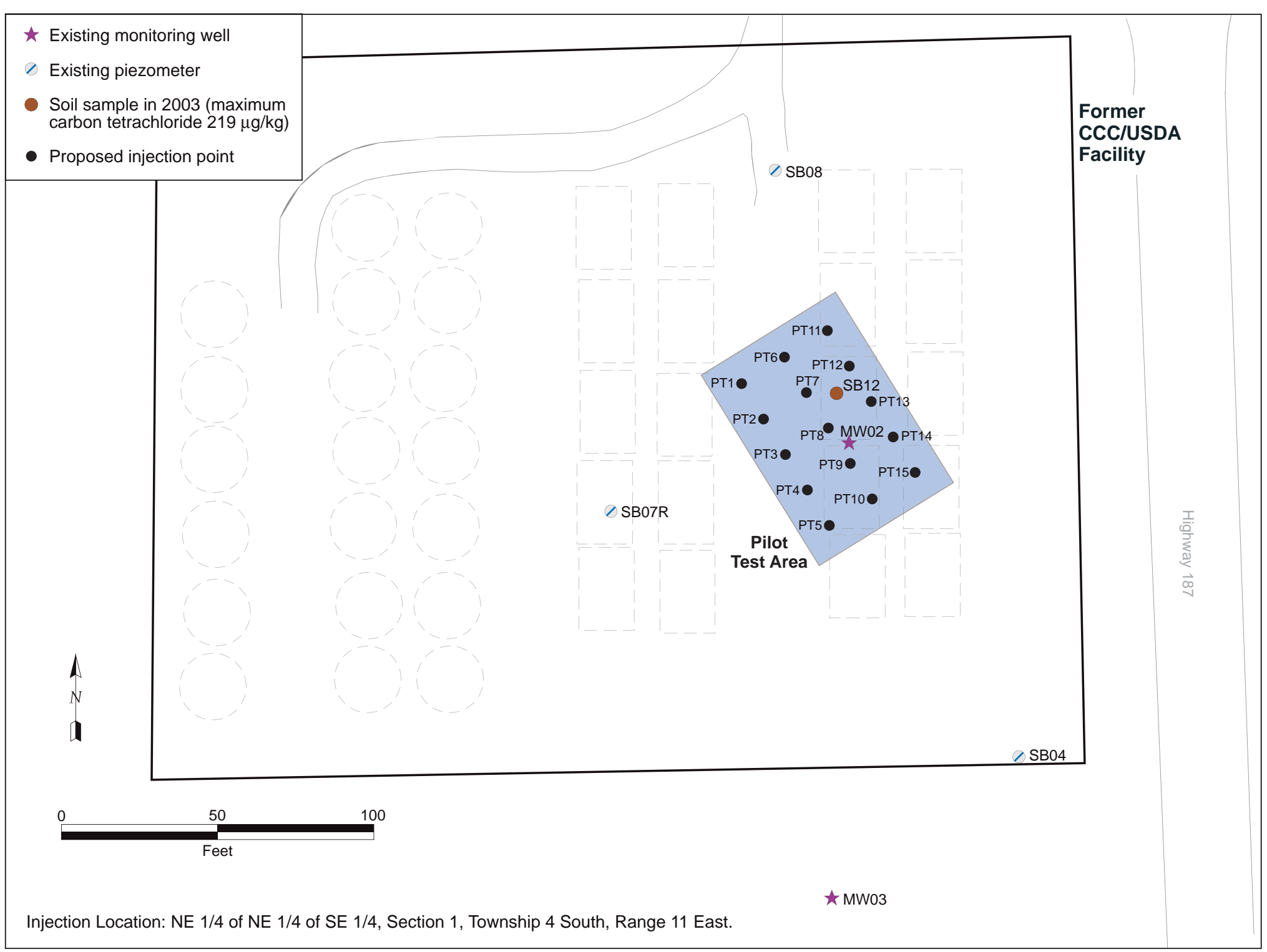

FIGURE 4.2 Proposed pilot test area at Centralia ( $45 \mathrm{ft} \times 75 \mathrm{ft}$ ), with locations of injection points (spaced on a 15-ft grid, with an anticipated radius of influence of $7.5 \mathrm{ft}$ ). 


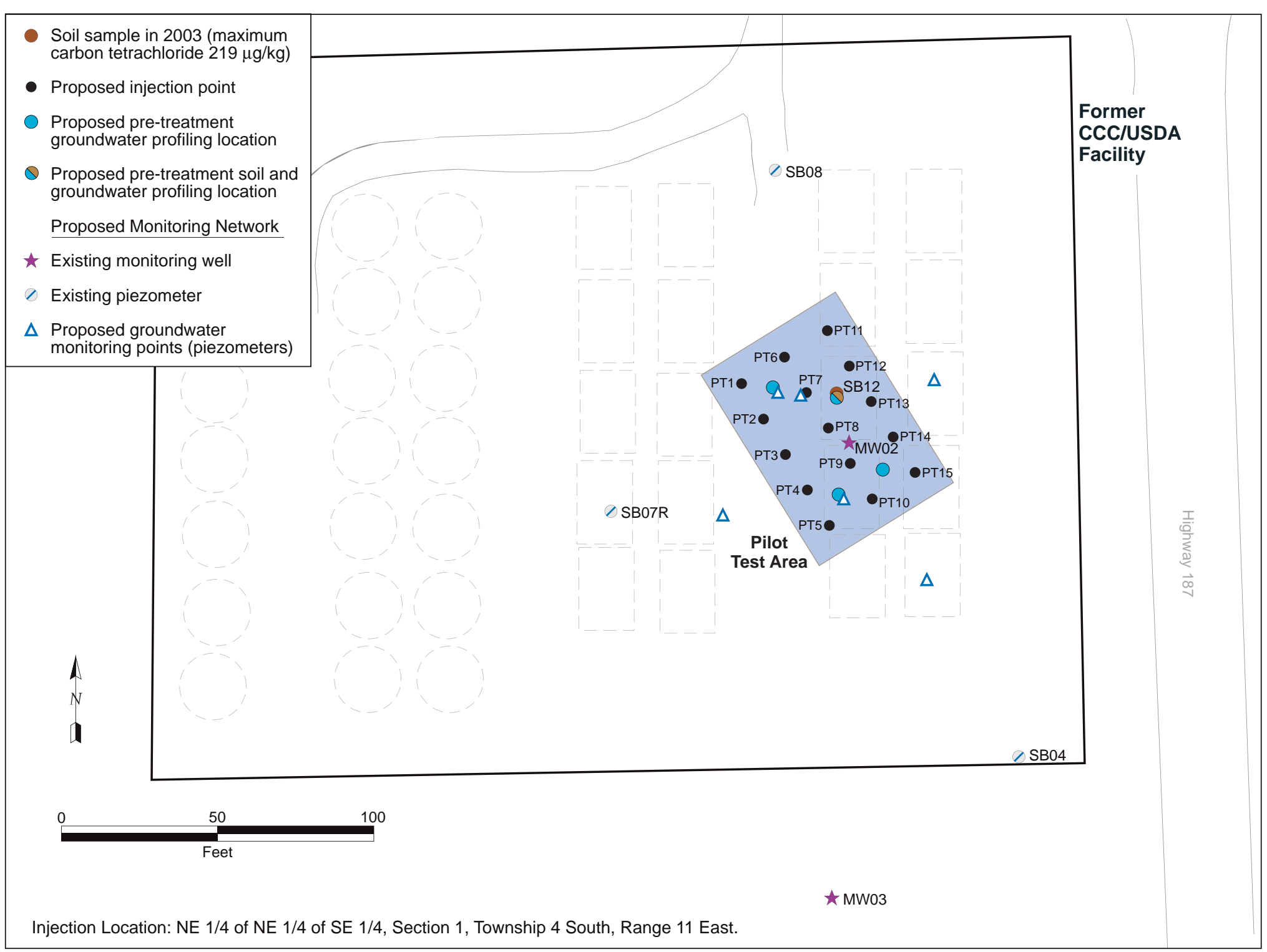

FIGURE 4.3 Proposed pilot test area at Centralia ( $45 \mathrm{ft} \times 75 \mathrm{ft}$ ), with locations of injection points (spaced on a 15-ft grid) and existing and new monitoring points. 


\section{References}

Adventus, 2006, News Release: Adventus Outlines In Situ Chemical Reduction (ISCR) Advantages, Adventus Americas, Inc., Freeport, Illinois, http:/www.adventusgroup.com/ pdfs/Release-ISCR\%20Oils.pdf, May 23, accessed August 17, 2007.

Adventus, 2007a, EHC ${ }^{\circledR}$ Technology Overview - Field Applications, Adventus Americas, Inc., Freeport, Illinois, http://www.adventusgroup.com/pdfs/EHC_applications.pdf, accessed August 16, 2007.

Adventus, 2007b, EHC ${ }^{\circledR}$ for Carbon Tetrachloride, Adventus Americas, Inc., Freeport, Illinois, http://www.adventusgroup.com/pdfs/EHC_CT.pdf, accessed August 16, 2007.

Adventus, 2007c, Field Profile: EHC ${ }^{\circledR}$ Treatment of Groundwater Plume Containing Chlorinated Solvents, Adventus Americas, Inc., Freeport, Illinois, http://www.adventusgroup. com/pdfs/EHC/Chlorinated\%20Solvents.pdf, accessed August 16, 2007.

Adventus, 2007d, Field Profile: Grain Silo Facility, Kansas, Adventus Americas, Inc., Freeport, Illinois, $\quad$ http://www.adventusgroup.com/pdfs/projects/Project\%20Description\%20\%20EHC\%20KS\%20Pirnie\%20APR07.pdf, accessed August 16, 2007.

Adventus, 2007e, The Adventus Range of Products, Adventus Americas, Inc., Freeport, Illinois, http://www.terrsula.com/Attachments/Product\%20Summary.pdf, accessed August 17, 2007.

Adventus, 2007f, CT Column Data: Results from Study with EHC and EHC-A, Adventus Americas, Inc., Freeport, Illinois, http://www.adventusgroup.com/pdfs/EHC/EHC-A for CT 2006-05.pdf, accessed August 17, 2007.

Amonette, J.E., 2006, "Reductive Degradation of Carbon Tetrachloride by Iron: Progress and Prognosis," in Symposia Papers presented before the Division of Environmental Chemistry, American Chemical Society, Atlanta, Georgia, March 26-30.

Argonne, 2002a, Final Work Plan: Phase I QuickSite Investigation, Centralia, Kansas, ANL/ER/TR-02/001, prepared for the Commodity Credit Corporation, U.S. Department of Agriculture, by Argonne National Laboratory, Argonne, Illinois, June. 
Argonne, 2002b, Final Master Work Plan: Environmental Investigations at Former CCC/USDA Facilities in Kansas, 2002 Revision, ANL/ER/TR-02/2004, prepared for the Commodity Credit Corporation, U.S. Department of Agriculture, by Argonne National Laboratory, Argonne, Illinois, December.

Argonne, 2003, Final Phase I Report and Phase II Work Plan: QuickSite Investigation, Centralia, Kansas, ANL/ER/TR-02/009, prepared for the Commodity Credit Corporation, U.S. Department of Agriculture, by Argonne National Laboratory, Argonne, Illinois, March.

Argonne, 2004, Final Phase II Report: QuickSite Investigation, Centralia, Kansas, ANL/ER/TR-03/006, prepared for the Commodity Credit Corporation, U.S. Department of Agriculture, by Argonne National Laboratory, Argonne, Illinois, March.

Argonne, 2005a, Final Work Plan: Groundwater Monitoring at Centralia, Kansas, ANL/ER/TR05/004, prepared for the Commodity Credit Corporation, U.S. Department of Agriculture, Washington, D.C. by Argonne National Laboratory, Argonne, Illinois, August.

Argonne, 2005b, Final Report: 2004 Monitoring Well Installation and Sampling at Centralia, Kansas, ANL/ER/TR-04/011, prepared for the Commodity Credit Corporation, U.S. Department of Agriculture, Washington, D.C. by Argonne National Laboratory, Argonne, Illinois, October.

Argonne, 2005c, Results of Fall 2005 Sampling at Centralia, Kansas, and Recommendations for Expansion of the Monitoring Network, ANL/EVS/AGEM/CHRON-906, prepared for the Commodity Credit Corporation, U.S. Department of Agriculture, Washington, D.C. by Argonne National Laboratory, Argonne, Illinois, November 18.

Argonne, 2006a, Final Report: Groundwater Monitoring at Centralia, Kansas, in SeptemberOctober 2005 and March 2006, with Expansion of the Monitoring Network in January 2006, ANL/EVS/AGEM/TR-06-06, prepared for the Commodity Credit Corporation, U.S. Department of Agriculture, Washington, D.C., by Argonne National Laboratory, Argonne, Illinois, October.

Argonne, 2006b, September Monitoring Results for Centralia, Kansas, ANL/EVS/AGEM/CHRON-1003, prepared for the Commodity Credit Corporation, U.S. Department of Agriculture, Washington, D.C., by Argonne National Laboratory, Argonne, Illinois, November 10. 
Argonne, 2007, March 2007 Monitoring Results for Centralia, Kansas, ANL/EVS/AGEM/TR/07-08, prepared for the Commodity Credit Corporation, U.S. Department of Agriculture, Washington, D.C., by Argonne National Laboratory, Argonne, Illinois, June.

Bouwer, H., 1989, “The Bouwer and Rice Slug Test: An Update,” Ground Water 27(3):304-309.

Bouwer, H., and R. Rice, 1976, "A Slug Test for Determining Hydraulic Conductivity of Unconfined Aquifers with Completely or Partially Penetrating Wells," Water Resources Research 12(3):423-428.

Dybas, M.J., M. Barcelona, S. Bezborodnikov, S. Davies, L. Forney, H. Heuer, O. Kawka, T. Mayotte, L. Sepulveda-Torres, K. Smalla, M. Sneathen, J. Riedje, T. Voice, D. Wiggert, M. Witt, and C.S. Criddle, 1998, "Pilot-Scale Evaluation of Bioaugmentation for In Situ Remediation of a Carbon Tetrachloride Contaminated Aquifer," Environmental Science and Technology 32:3598-3611.

EPA, 1998, Technical Protocol for Evaluating Natural Attenuation of Chlorinated Solvents in Ground Water, EPA/600/R-98/128, Office of Research and Development, U.S. Environmental Protection Agency, Washington, D.C., September (http://www.epa.gov/correctiveaction/ resource/guidance/rem_eval/protocol.pdf).

Fogel, M., A.R. Taddeo, and S. Fogel, 1986, "Biodegradation of Chlorinated Ethenes by a Methane-Utilizing Mixed Culture," Applied and Environmental Microbiology 51:720-724.

Henson, J.M., M.V. Yates, J.W. Cochran, and D.L. Schackleford, 1988, "Microbial Removal of Halogenated Methanes, Ethanes, and Ethylenes in an Aerobic Soil Column Exposed to Natural Gas," FEMS Microbiology Letters, 53:193-201.

Hvorslev, M.J., 1951, Time Lag and Soil Permeability in Ground-Water Observations, Bulletin No. 36, Waterways Experiment Station, Corps of Engineers, U.S. Army, Vicksburg, Mississippi, pp. 1-50.

KDHE, 1996, Policy and Scope of Work: Interim Measures, BER Policy \#BER-RS-029, Bureau of Environmental Remediation/Remedial Section, Kansas Department of Health and 
Environment, Topeka, Kansas, Revised October 2006 (http://www.kdheks.gov/ber/policies/ BER_RS_029.pdf), accessed August 15, 2007.

KDHE, 2001, Monitored Natural Attenuation, BER Policy \#BER-RS-042, Bureau of Environmental Remediation/Remedial Section, Kansas Department of Health and Environment, Topeka, Kansas, Revised December 2005 (http://www.kdheks.gov/ber/policies/ BER_RS_042.pdf), accessed August 15, 2007.

KDHE, 2007a, Risk Based Standards for Kansas: RSK Manual, 4thVersion, Bureau of Environmental Remediation, Kansas Department of Health and the Environment, June (http://www.kdheks.gov/remedial/download/ RSK_Manual_07.pdf), accessed August 15, 2007.

KDHE, 2007b, Cargill Flour Mill and Elevator, Kansas Department of Health and Environment, Bureau of Environmental Remediation Identified Sites List Information, Project Code C209670158, http://kensas.kdhe.state.ks.us/pls/certop/Iop?id=C209670158, accessed August 15, 2007.

Vogel, T.M., C.S. Criddle, and P.L. McCarty, 1987, "Transformations of Halogenated AliphaticCompounds," Environmental Science and Technology 21:722-736.

Wang, C., and W. Zhang, 1997, "Synthesizing Nanoscale Iron Particles for Rapid and Complete Dechlorination of TCE and PCBs," Environmental Science and Technology 31:2154-2156. 


\section{Appendix A:}

Slug Testing of Monitoring Wells and Piezometers at Centralia (October 2006) 


\section{Appendix A:}

\section{Slug Testing of Monitoring Wells and Piezometers at Centralia (October 2006)}

\section{A.1 Background}

Argonne's investigations at Centralia (Argonne 2003, 2004) demonstrated that the shallow aquifer affected by the carbon tetrachloride contamination is composed of glacial outwash sediments ranging from fine grained silts and clay to gravelly, medium to coarse sands. The areal and vertical distribution of these sediment types is heterogeneous; relatively thicker deposits of coarser grained sands and gravels have been identified in the eastern, northern, and western portions of the study area, while silts and clays are more prominently developed in the area near the southwestern corner of the former CCC/USDA facility (Figure 1.4). This distribution qualitatively mirrors persistent water level patterns observed at the site, which indicate that hydraulic gradients increase rapidly toward the southwestern corner of the former facility (Figure 1.7). Together, these data suggested that the observed variations in hydraulic gradients largely reflect spatial variations in the hydraulic conductivity of the aquifer sediments.

With the approval of the CCC/USDA, Argonne conducted single-well response ("slug") testing of selected monitoring wells and piezometers at Centralia to obtain quantitative information on the in situ hydraulic properties of the shallow aquifer. The results of these tests are summarized below.

\section{A.2 Investigation Methods}

Slug testing was performed at Centralia on October 23-25, 2006, at monitoring wells MW01, MW02, MW04, MW06, MW07, MW08, and MW10 and piezometers SB01, SB04, SB05, SB07R, and SB08. The locations are shown relative to the former CCC/USDA facility and the carbon tetrachloride plume in Figure 1.8. All of the locations tested have been purged repeatedly in conjunction with the extended monitoring program in progress at this site (Argonne 2005a); no additional efforts to develop each boring were therefore made prior to the hydraulic testing. 
The tests at MW02, MW08, MW10, SB04, SB05, SB07R, and SB08 were performed by using pressurized air to depress and stabilize the water level in the well or piezometer casing. To initiate each test, the air pressure was released to create a condition equivalent to an instantaneous drop in head. The use of this pneumatic method proved logistically impractical for the tests at MW01, MW04, MW06, MW07, and SB01, because of the very long air pressure equilibration times required prior to the initiation of each test. This problem was a result of relatively low aquifer hydraulic conductivity; see Section A.3.

The slug tests at MW01, MW04, MW06, MW07, and SB01 were conducted by quickly lowering or withdrawing a physical slug into the casing to perturb the static water column. For this purpose, the following physical slugs were used: a 4-ft-long, 0.5-in.-diameter solid steel rod at SB01; a 4-ft-long, 1.5-in.-diameter sealed, sand-filled PVC [polyvinyl chloride] pipe at MW01, MW04, and MW06; and a 3-ft-long, 1.25-in.-diameter sealed, sand-filled PVC pipe at MW07.

The water level responses for all of the tests performed by using the air pressurization method, as well as for the physical slug test performed at MW01, were recorded by using a downhole pressure transducer connected to an automatic data logger (Hermit ${ }^{\mathrm{TM}}$ 1000C). Water level responses for the remaining tests were recorded by using self-contained, downhole pressure-sensing and data-logging units (MiniTroll ${ }^{\mathrm{TM}}$ Pro Model). Both sensing and recording systems permitted data acquisition at high rates.

The slug test procedure was performed three times at MW02, MW08, MW10, SB04, SB05, and SB08. Because of prolonged response times, the procedure was performed only twice at MW04, MW06, MW07, SB01, and SB07R and once at MW01.

\section{A.3 Results and Discussion}

The overall results of the slug tests are summarized in Figure A.1. Representative interpretations for the individual tests are in Figures A.2-A.13. The figures are grouped after the text of Appendix A.

The hydraulic conductivity estimates resulting from the slug tests are summarized in Table A.1. Complete data (time versus residual drawdown) for the slug tests and the well (or 
piezometer) construction parameters required for data analysis are in Tables A.12-A.13. The data tables are grouped at the end of Appendix A, after the figures.

To generate estimates of hydraulic conductivity, the water level response data generated by the slug tests at Centralia were interpreted by using the analysis methods of Bouwer and Rice (Bouwer and Rice 1976; Bouwer 1989) and Hvorslev (1951), as implemented in the commercial well test software analysis package AqteSolv for Windows. Numerous alternative slug test analysis methods have been developed, each with advantages and disadvantages. The methods used for this study were selected in light of their relatively wide applicability, their level of documentation and general acceptance by the scientific community, and their ease of implementation to achieve the objective of estimating hydraulic parameters for the aquifer materials.

Representative (manual) curve fits for the test data are in Figures A.2-A.13. The hydraulic conductivity values calculated for each location by using either analysis method are dependent, in part, on the assumed thickness of the aquifer that responds to the water level offset produced during a test. Unambiguous identification of the effective aquifer interval affected by slug testing is difficult at numerous locations at Centralia because of the silty to clayey character of the sediments generally present. In light of this observation and the relatively small volume of water displaced during each slug test, hydraulic conductivities were estimated under the assumption that a thickness of sediments equal to the associated screen length contributed to the water level response at each tested location. The resulting hydraulic conductivity estimates are summarized in Table A.1. For each data set (Tables A.2-A.13), the estimated hydraulic conductivity values calculated with the Bouwer and Rice method were of the same magnitude as, but roughly $25 \%$ lower than, values for the same data set calculated with the Hvorslev method.

The estimated hydraulic conductivity values for the shallow aquifer sediments at Centralia ranged over four orders of magnitude, from approximately $0.001 \mathrm{ft} / \mathrm{day}$ at SB01 to approximately $22 \mathrm{ft} /$ day at SB08. The values calculated by using the Hvorslev method are in Figure A.1. The areal distribution of hydraulic conductivities estimated by using either analysis method support the interpretation of water level and lithologic data outlined above.

The results indicate a significant reduction in the permeability of the aquifer materials associated with the increased hydraulic gradients near the southwest corner of the former CCC/USDA facility (roughly parallel to its southern boundary). The estimated hydraulic 
conductivities associated with the coarser grained deposits identified at MW02, SB04, SB05, and SB08 range from roughly $2 \mathrm{ft} /$ day to approximately $22 \mathrm{ft} /$ day. In contrast, those near the southern margin of the former facility are consistently less than approximately $0.2 \mathrm{ft} / \mathrm{day}$. 


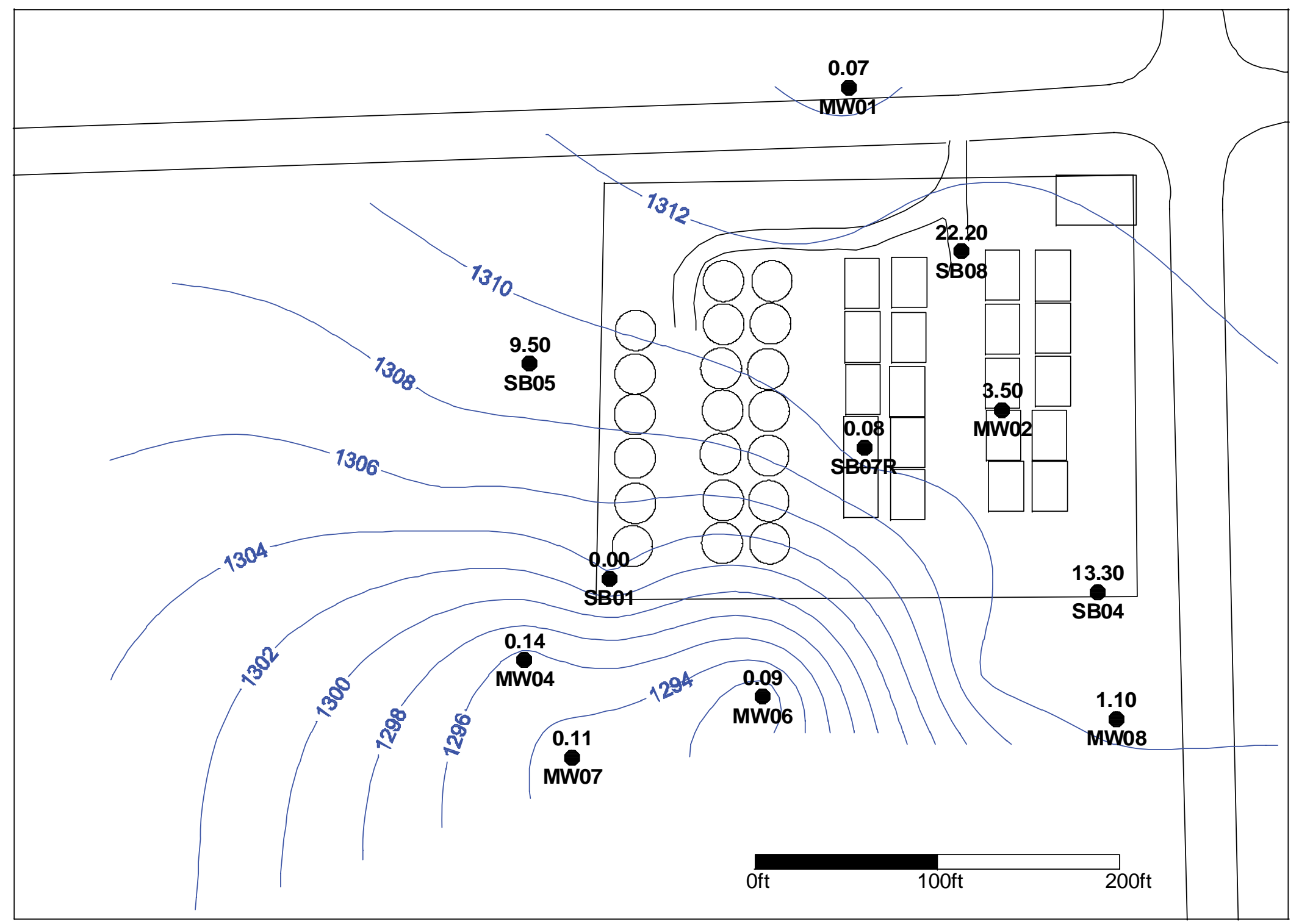

FIGURE A.1 Potentiometric surface at Centralia, based on water levels measured manually on June 16, 2006, and estimates of hydraulic conductivity (calculated by using the Hvorslev method) from slug tests performed on October 23-25, 2006. 
Interim Remedial Measure for Centralia, Kansas: Conceptual Design and Pilot Test

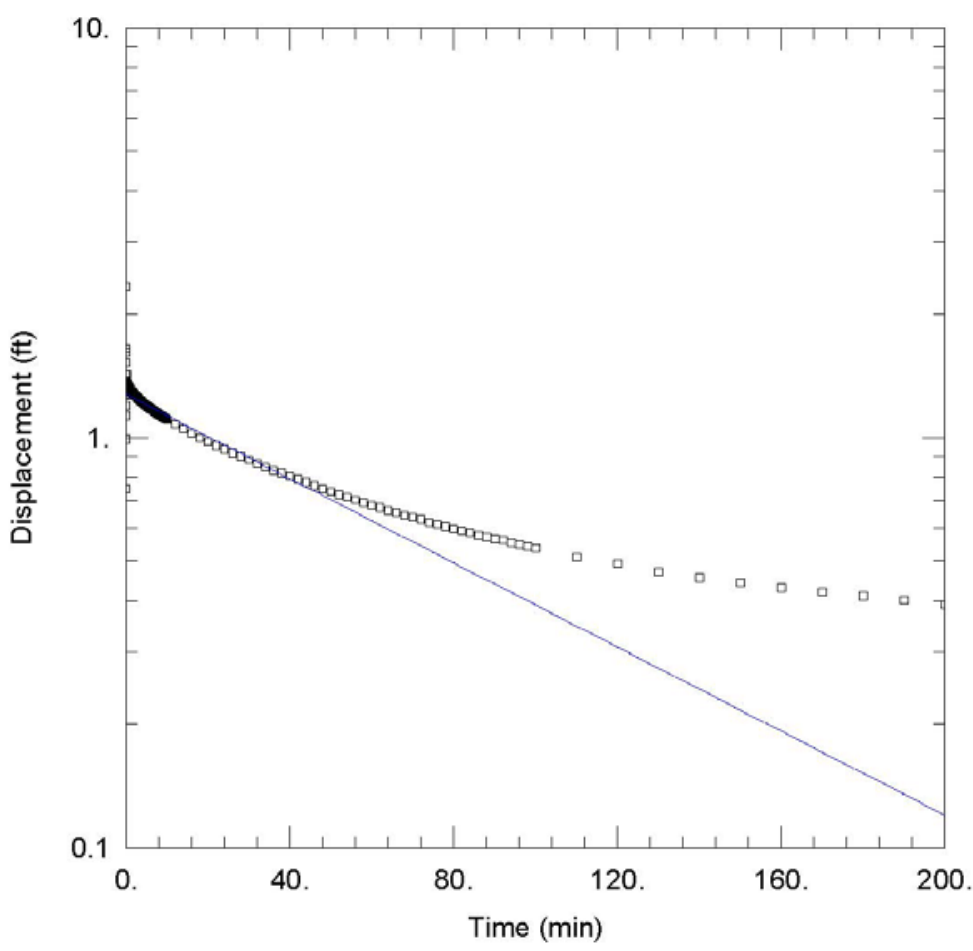

Observed slug test water level response and interpretive straightline fit to the measured data for MW01, Slug In.

FIGURE A.2 Observed slug test water level response and interpretive fit for the data for MW01 shown in Table A.2. 


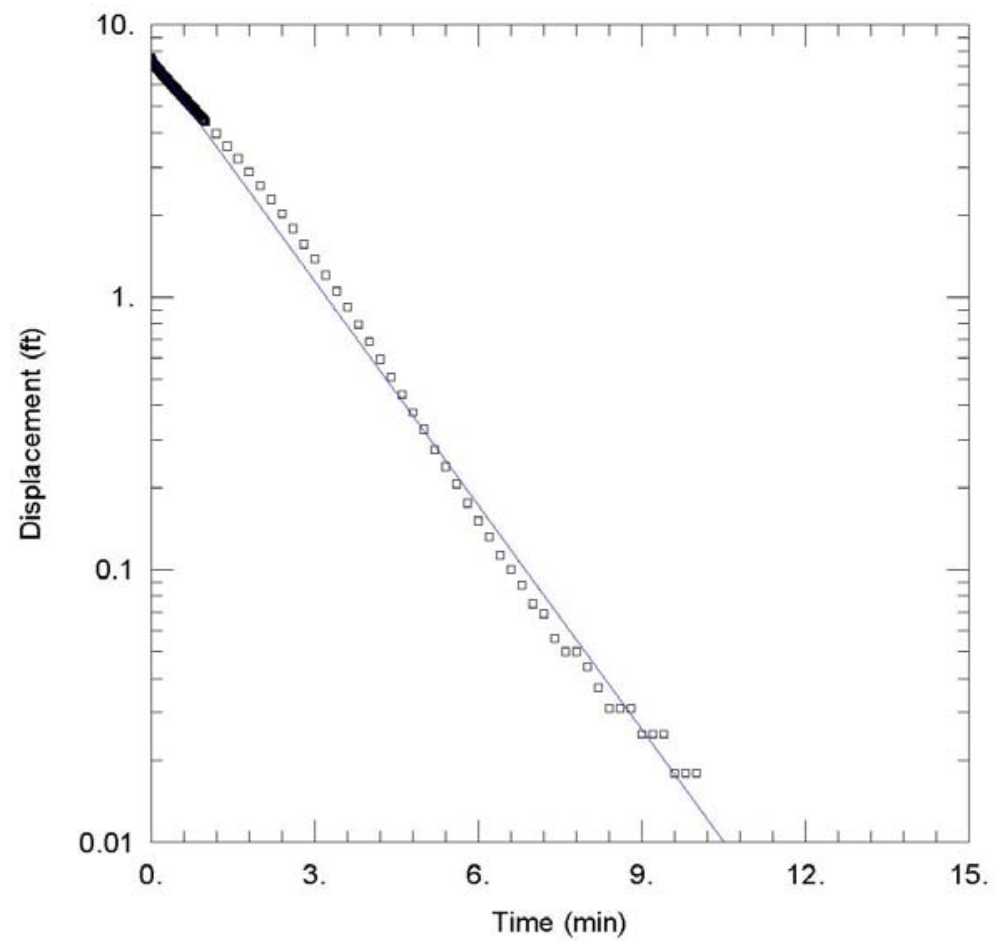

Observed slug test water level response and interpretive straightline fit to the measured data for MW02 Test 2, Step 0.

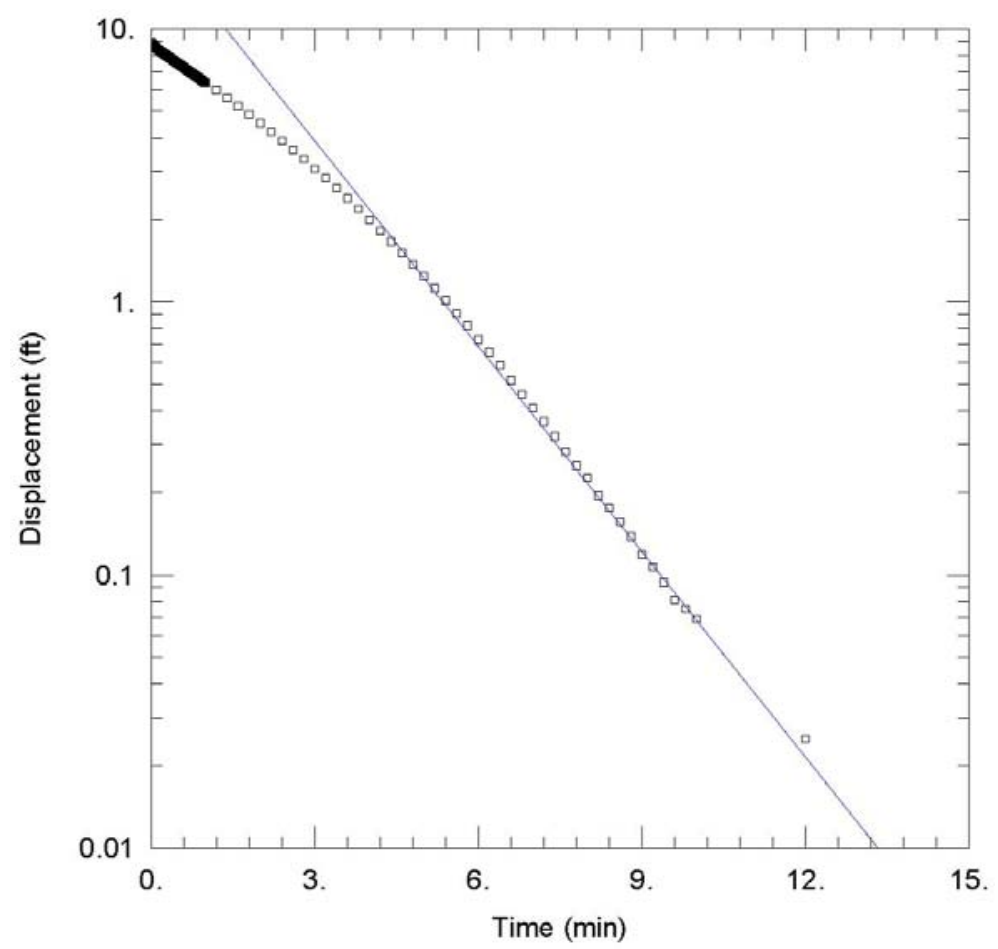

Observed slug test water level response and interpretive straightline fit to the measured data for MW02 Test 2, Step 1.

FIGURE A.3 Observed slug test water level response and interpretive fit for the data for MW02 shown in Table A.3. 


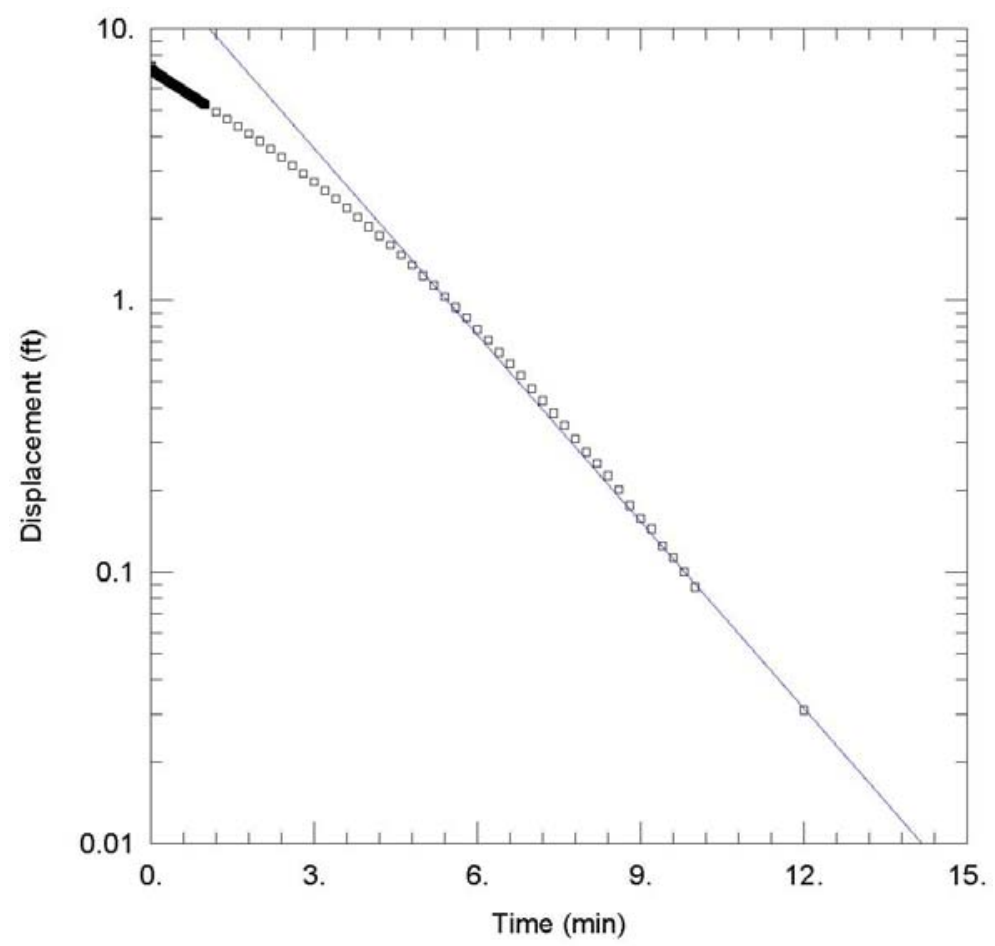

Observed slug test water level response and interpretive straightline fit to the measured data for MW02 Test 2, Step 2.

FIGURE A.3 (Cont.) 


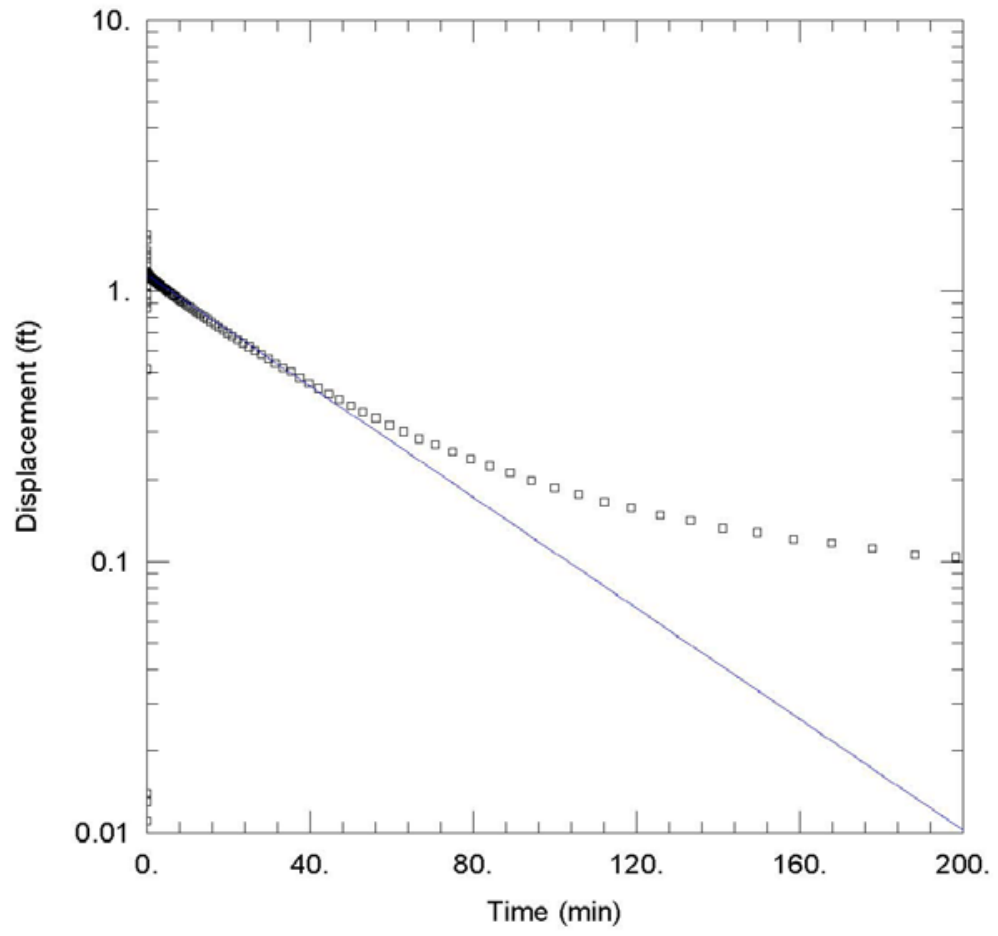

Observed slug test water level response and interpretive straightline fit to the measured data for MW04 Slug In.

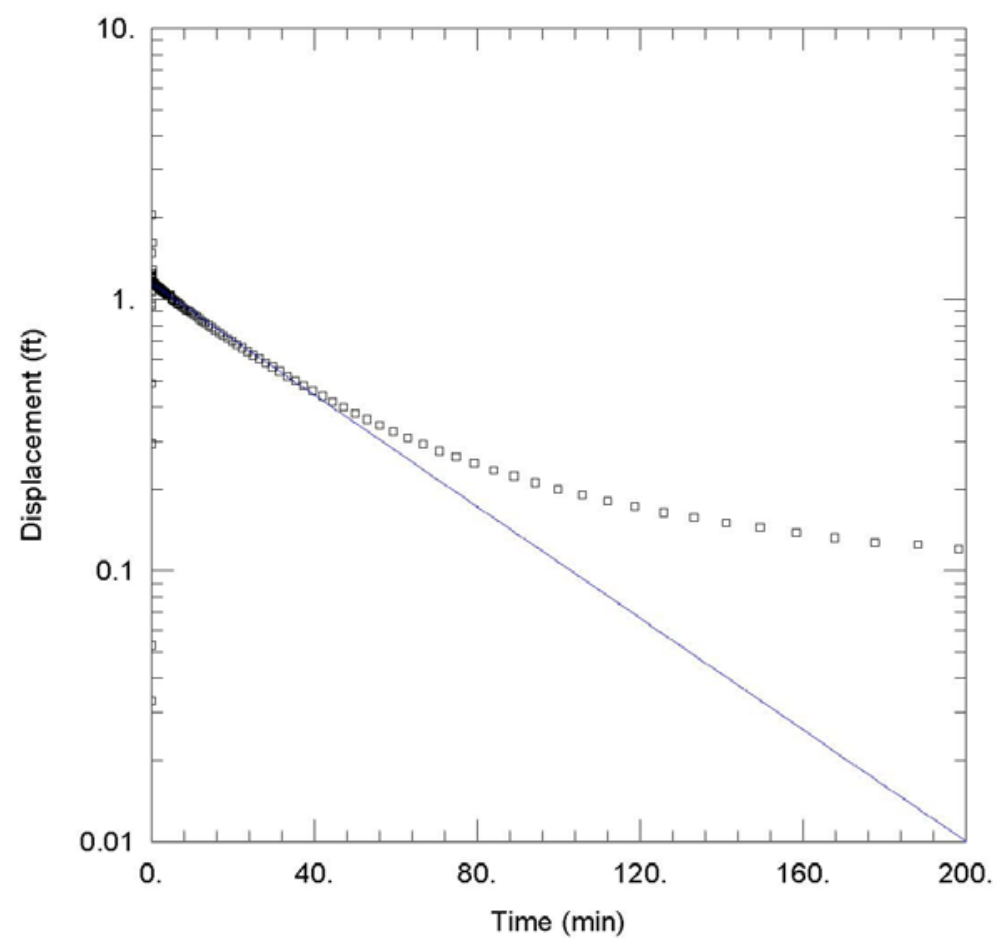

Observed slug test water level response and interpretive straightline fit to the measured data for MW04 Slug Out.

FIGURE A.4 Observed slug test water level response and interpretive fit for the data for MW04 shown in Table A.4. 


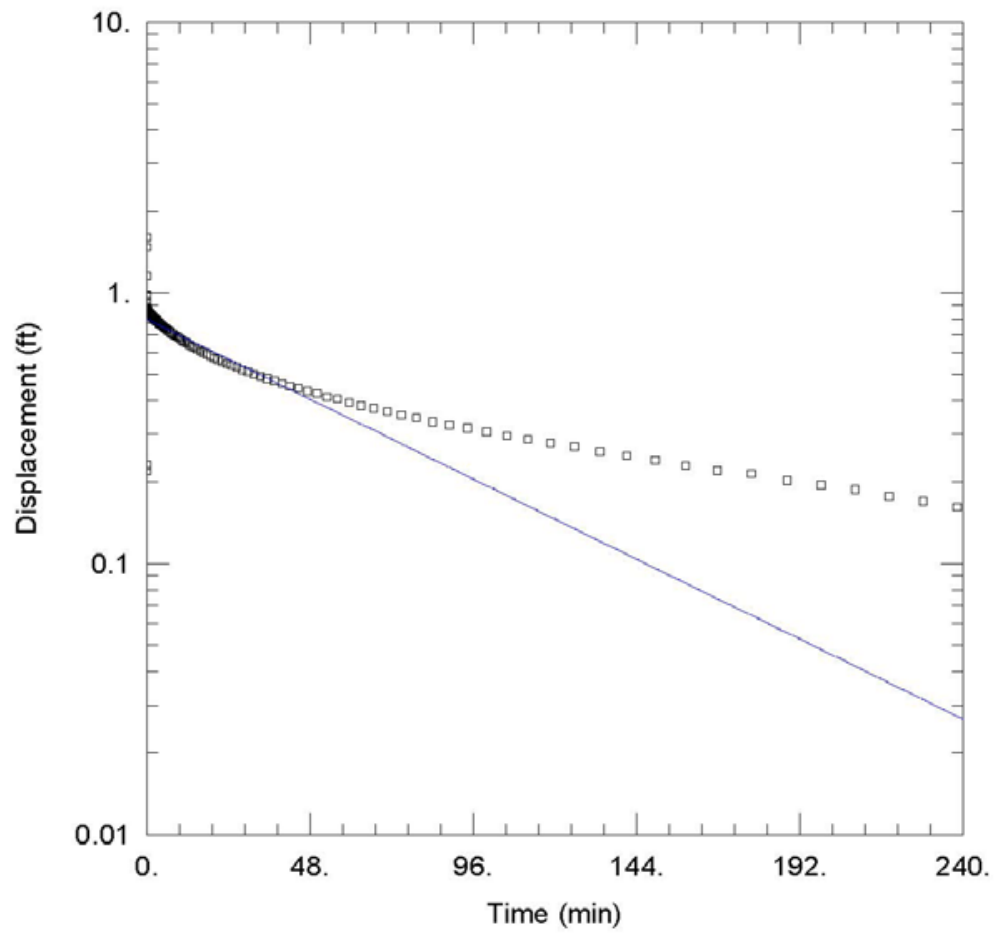

Observed slug test water level response and interpretive straightline fit to the measured data for MW06 Slug In.

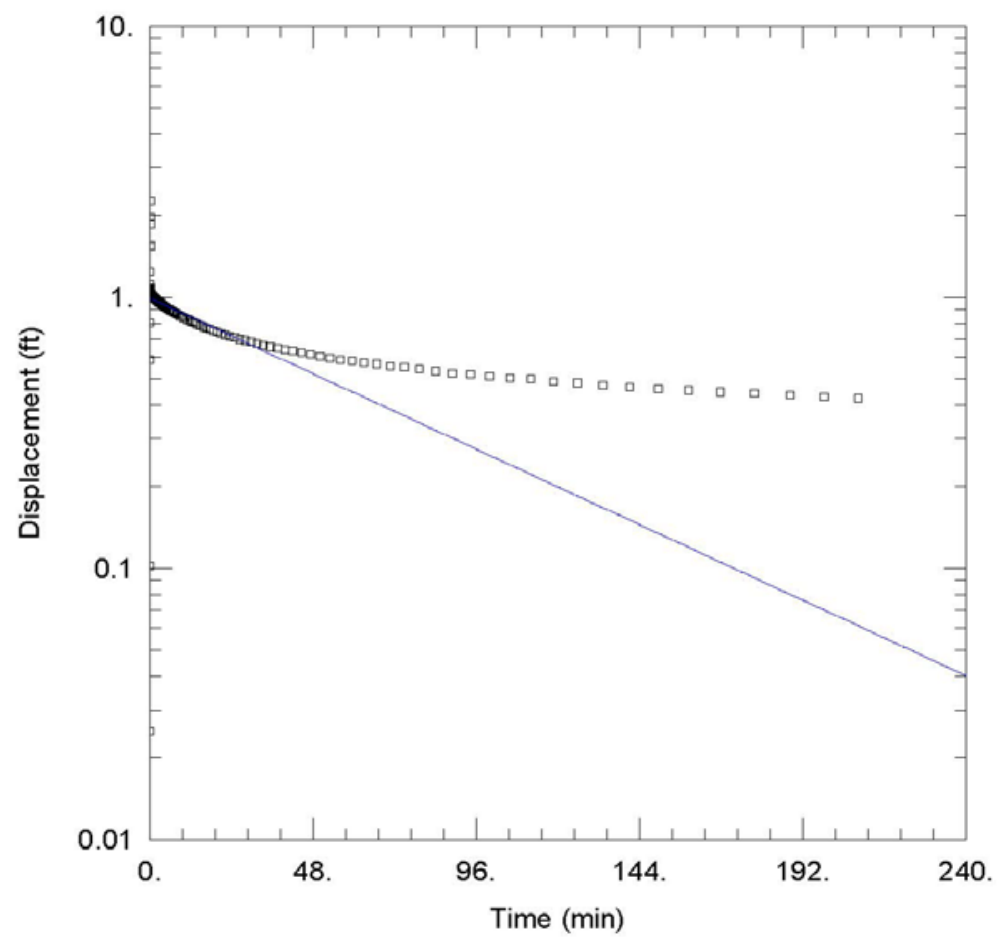

Observed slug test water level response and interpretive straightline fit to the measured data for MW06 Slug Out.

FIGURE A.5 Observed slug test water level response and interpretive fit for the data for MW06 shown in Table A.5. 


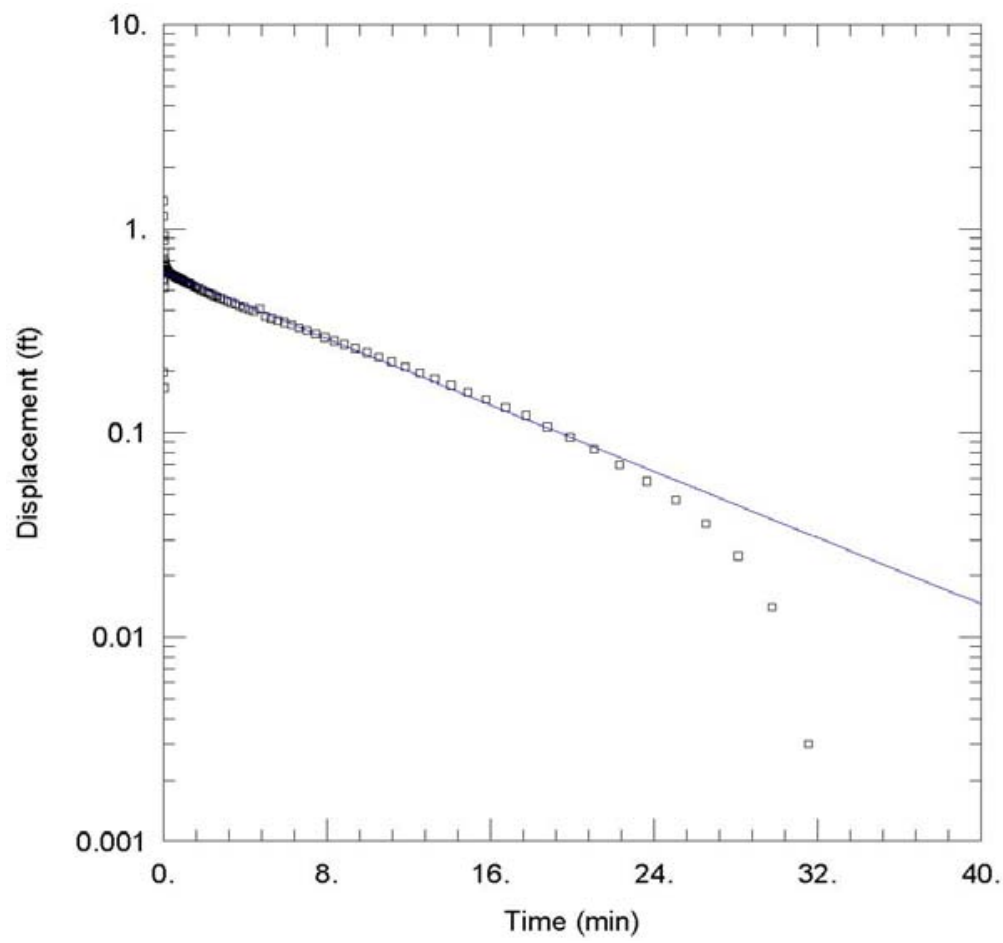

Observed slug test water level response and interpretive straightline fit to the measured data for MW07 Slug In.

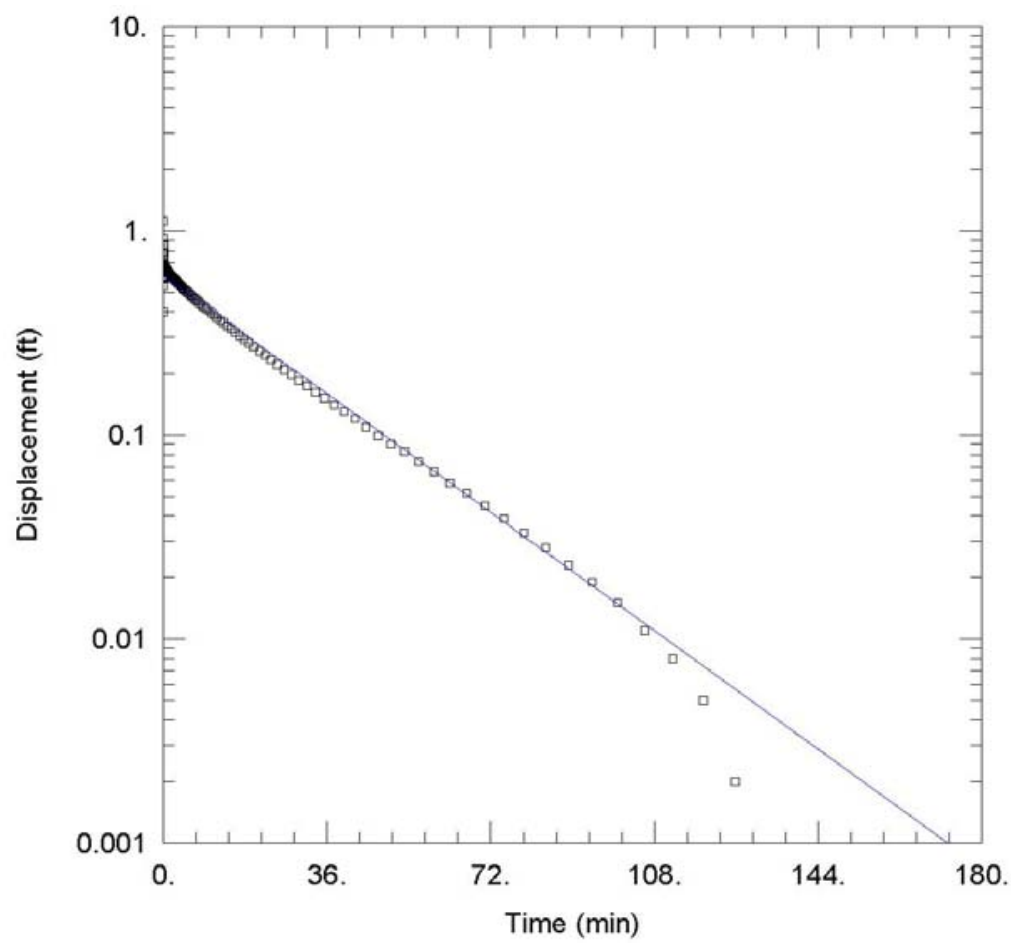

Observed slug test water level response and interpretive straight-line fit to the measured data for MW07 Slug Out.

FIGURE A.6 Observed slug test water level response and interpretive fit for the data for MW07 shown in Table A.6. 


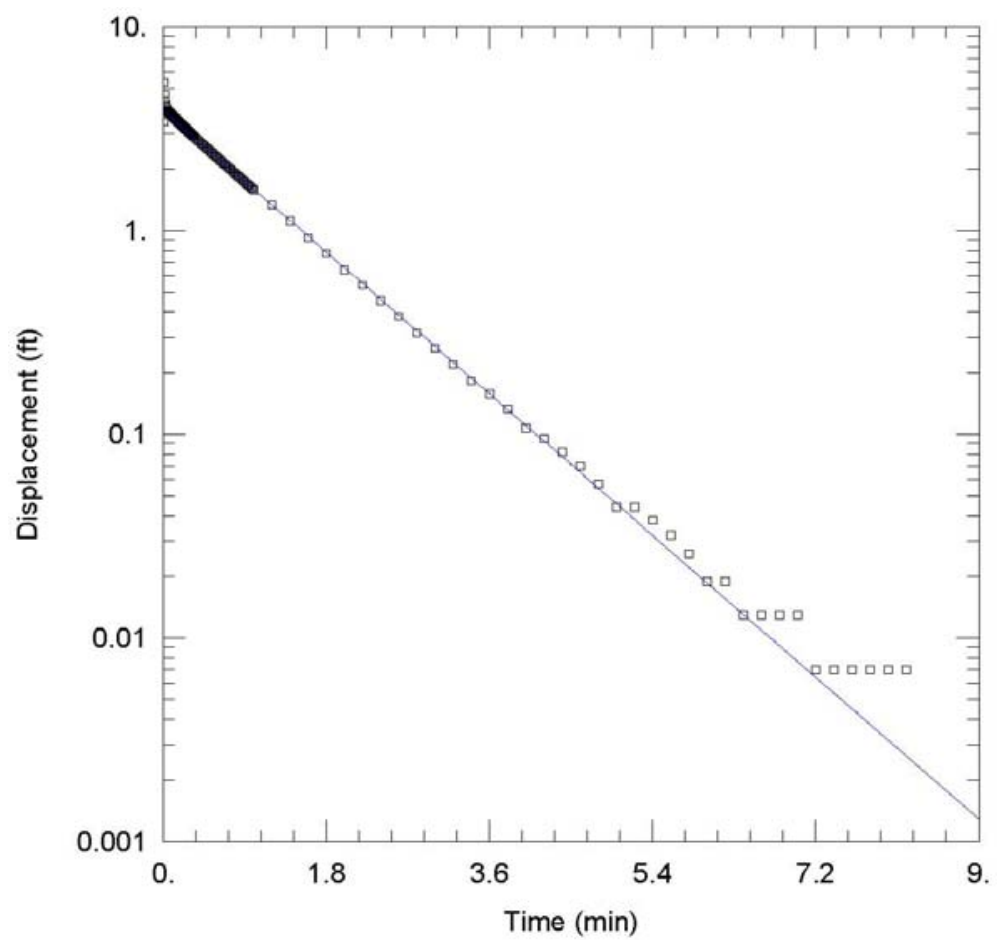

Observed slug test water level response and interpretive straightline fit to the measured data for MW08 Test 6, Step 0.

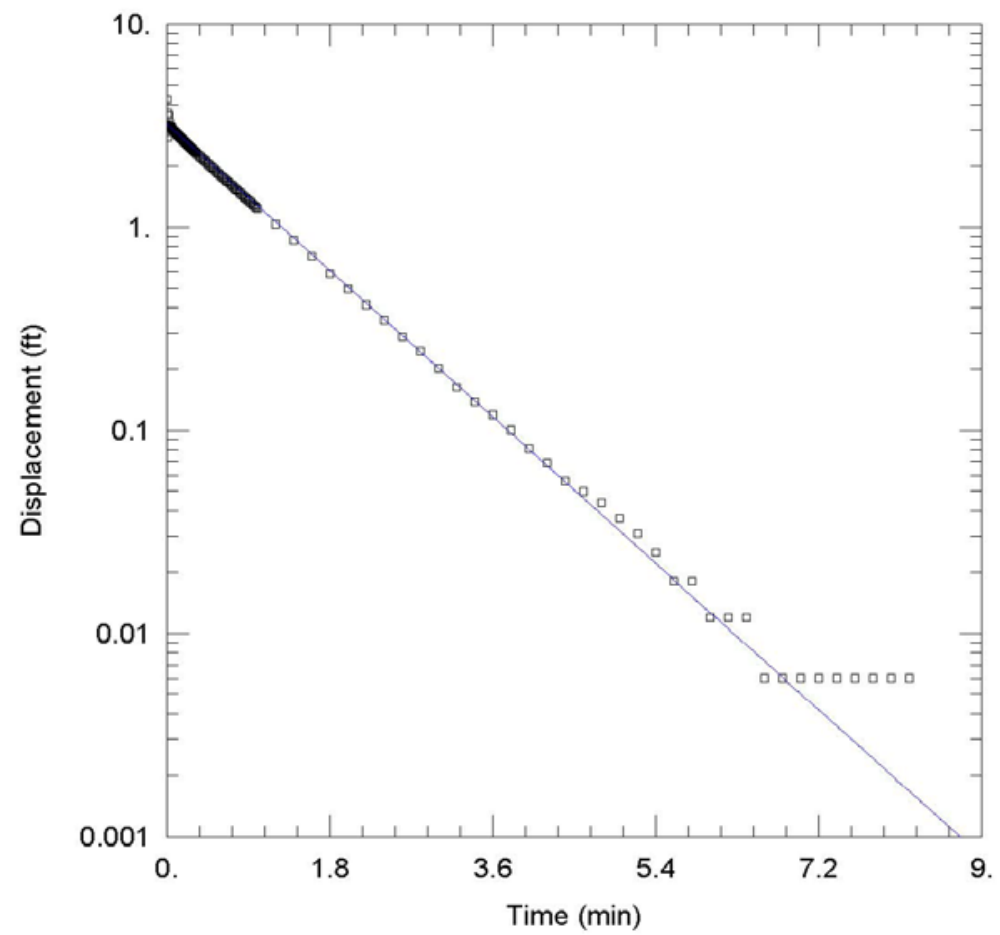

Observed slug test water level response and interpretive straightline fit to the measured data for MW08 Test 7, Step 0.

FIGURE A.7 Observed slug test water level response and interpretive fit for the data for MW08 shown in Table A.7. 
Interim Remedial Measure for Centralia, Kansas: Conceptual Design and Pilot Test Version 00, 08/30/07

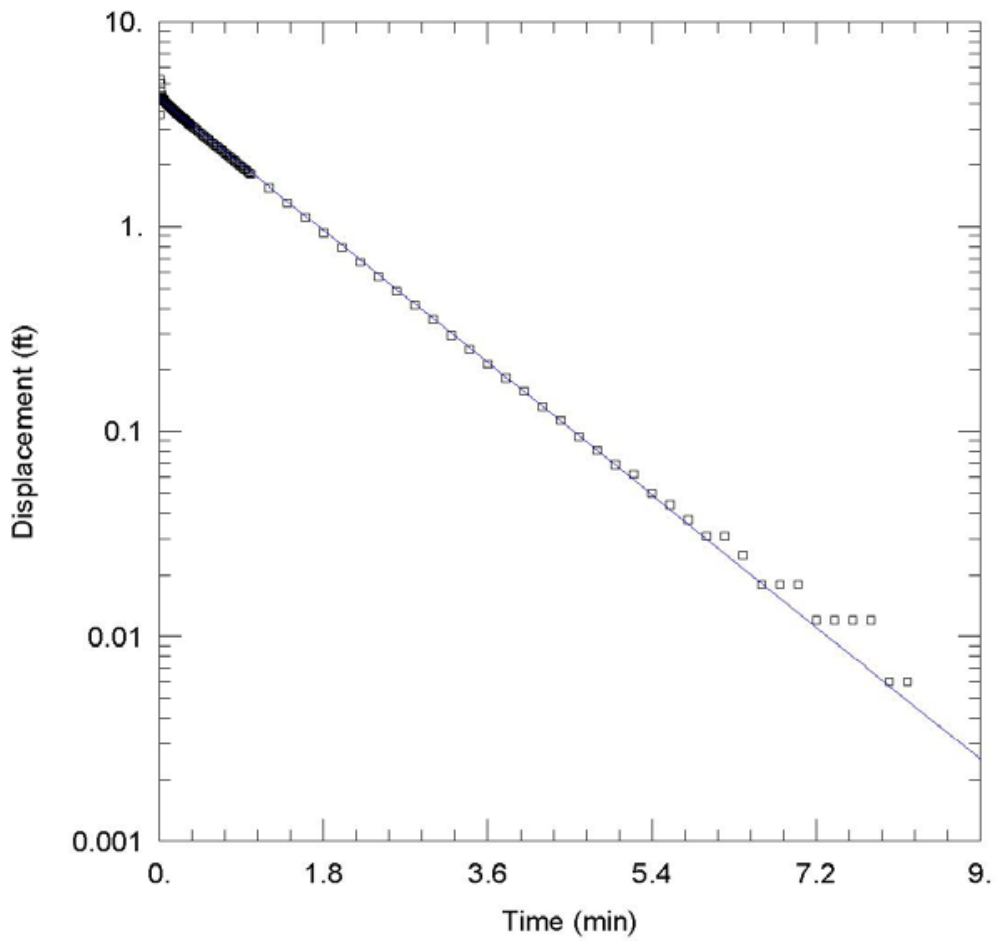

Observed slug test water level response and interpretive straightline fit to the measured data for MW08 Test 7, Step 1.

FIGURE A.7 (Cont.) 


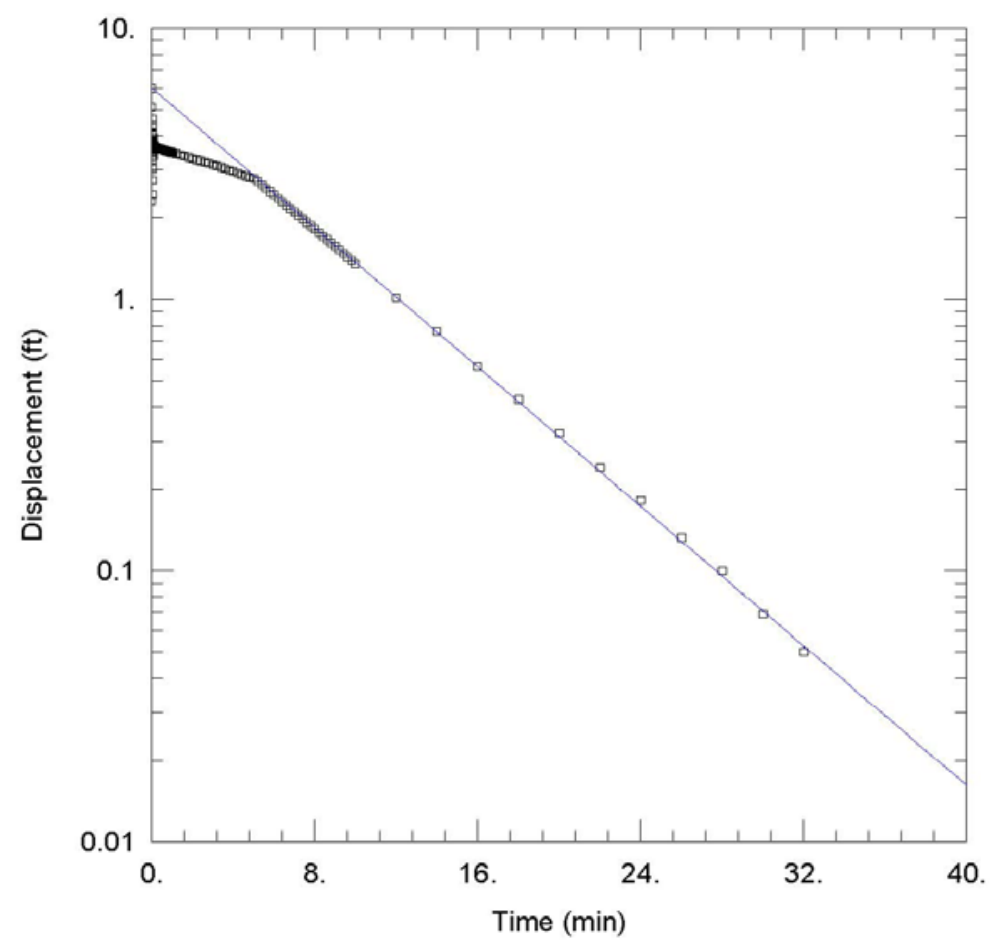

Observed slug test water level response and interpretive straight-line fit to the measured data for MW10 Test 0, Step 0.

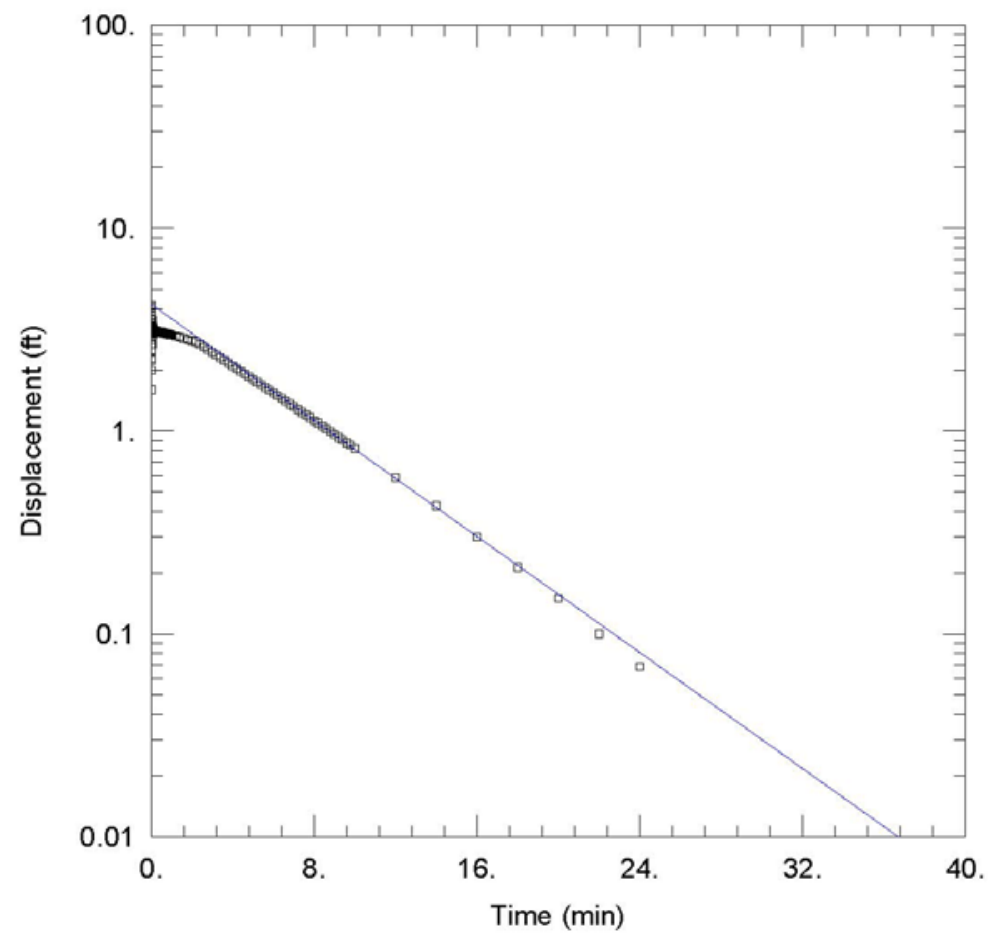

Observed slug test water level response and interpretive straightline fit to the measured data for MW10 Test 0, Step 1.

FIGURE A.8 Observed slug test water level response and interpretive fit for the data for MW10 shown in Table A.8. 


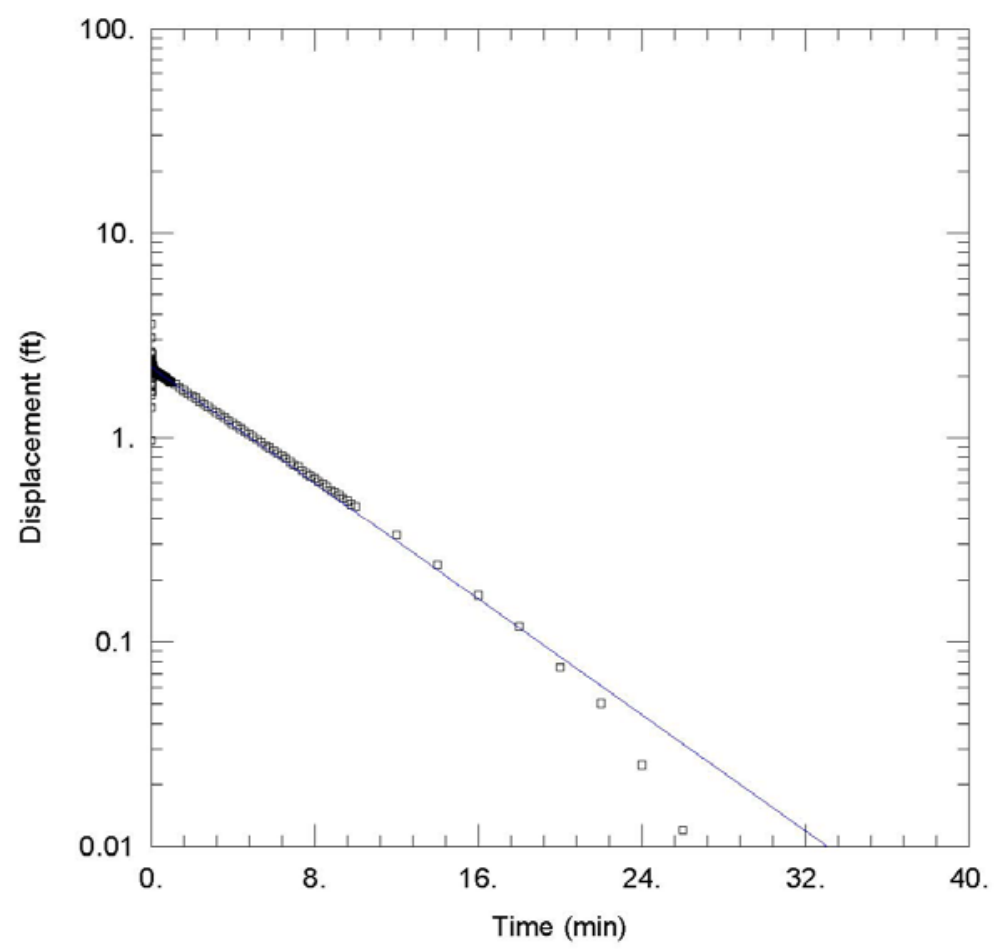

Observed slug test water level response and interpretive straightline fit to the measured data for MW10 Test 0, Step 2.

FIGURE A.8 (Cont.) 


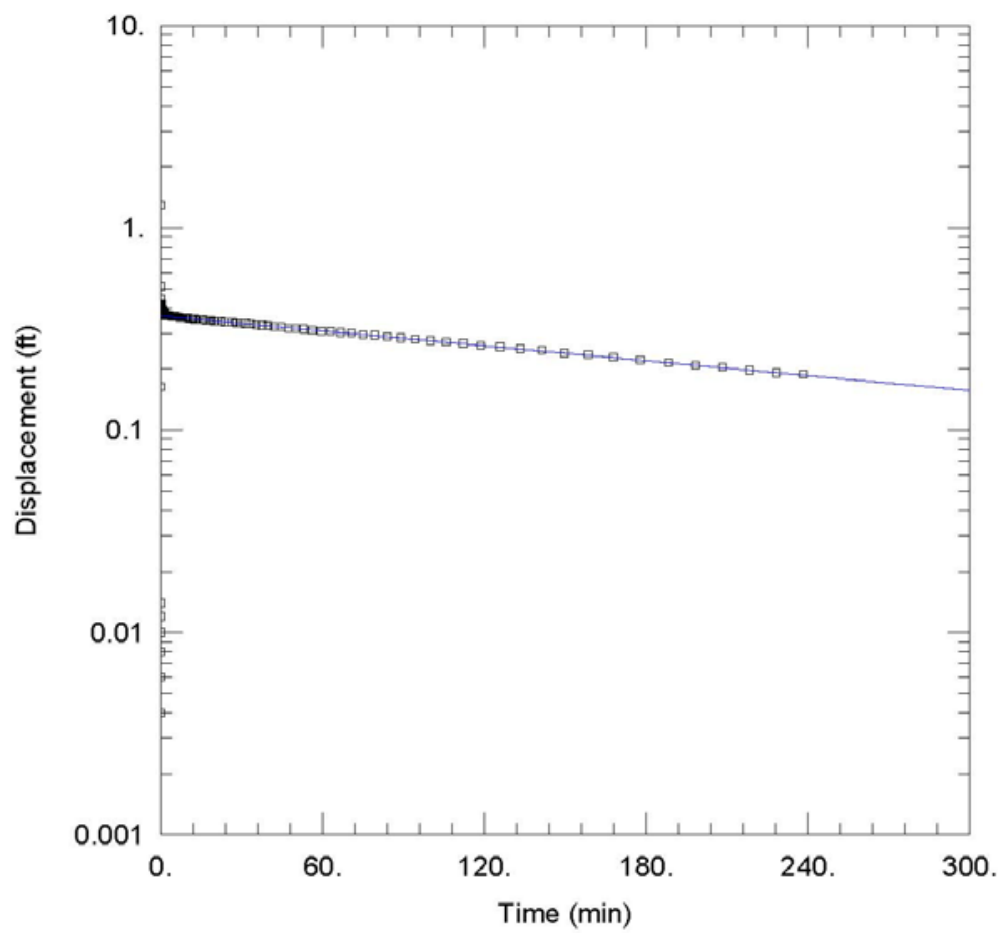

Observed slug test water level response and interpretive straightline fit to the measured data for SB01 Slug In.

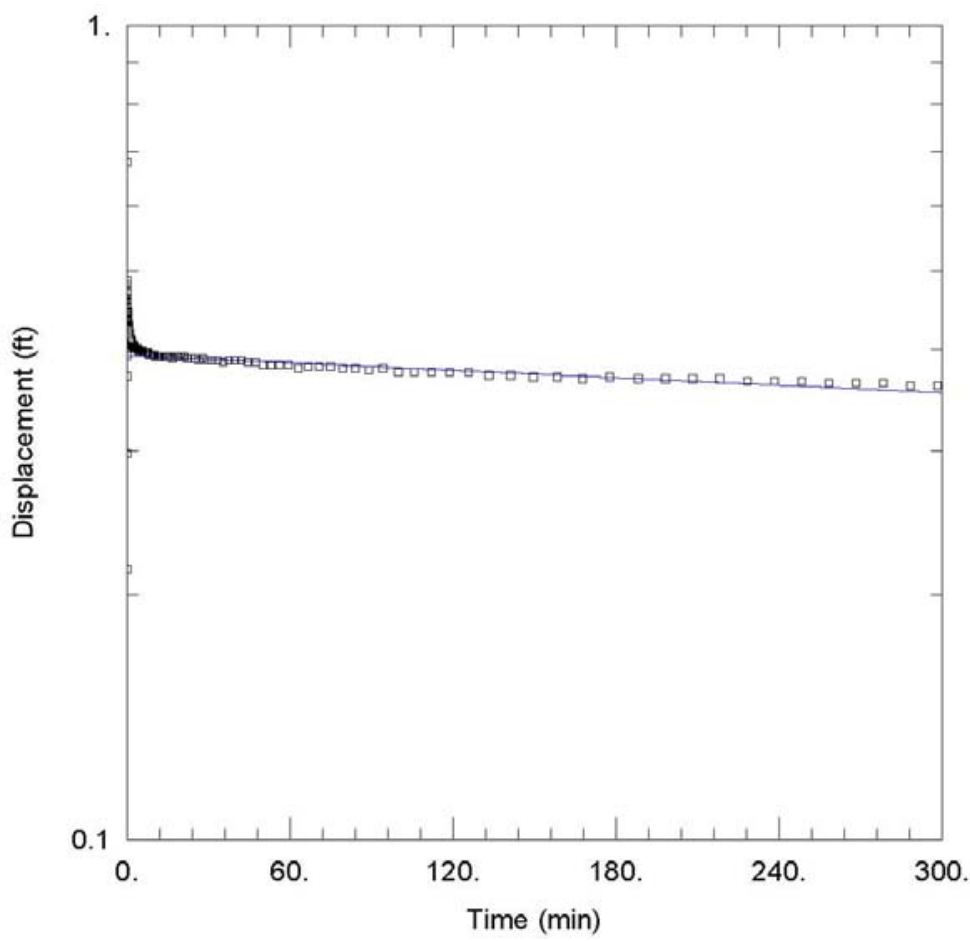

Observed slug test water level response and interpretive straightline fit to the measured data for SB01 Slug Out.

FIGURE A.9 Observed slug test water level response and interpretive fit for the data for SB01 shown in Table A.9. 


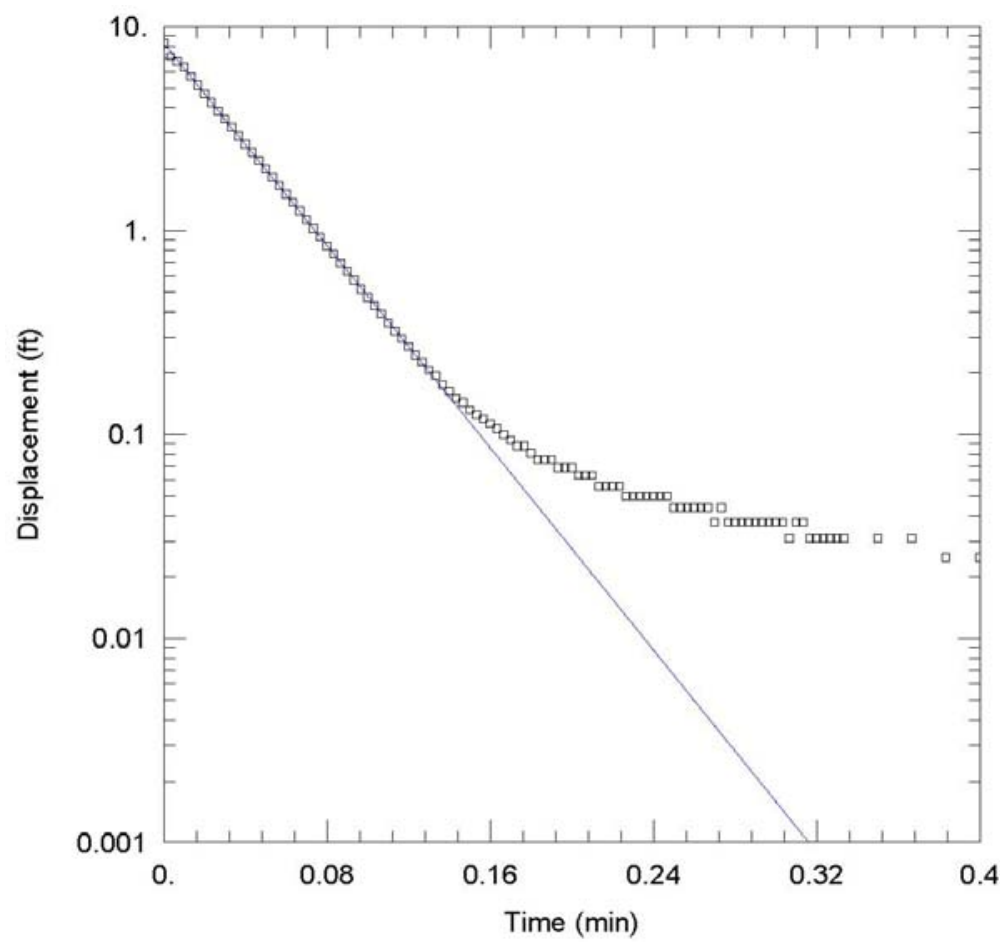

Observed slug test water level response and interpretive straight-line fit to the measured data for SB04 Test 1, Step 0.

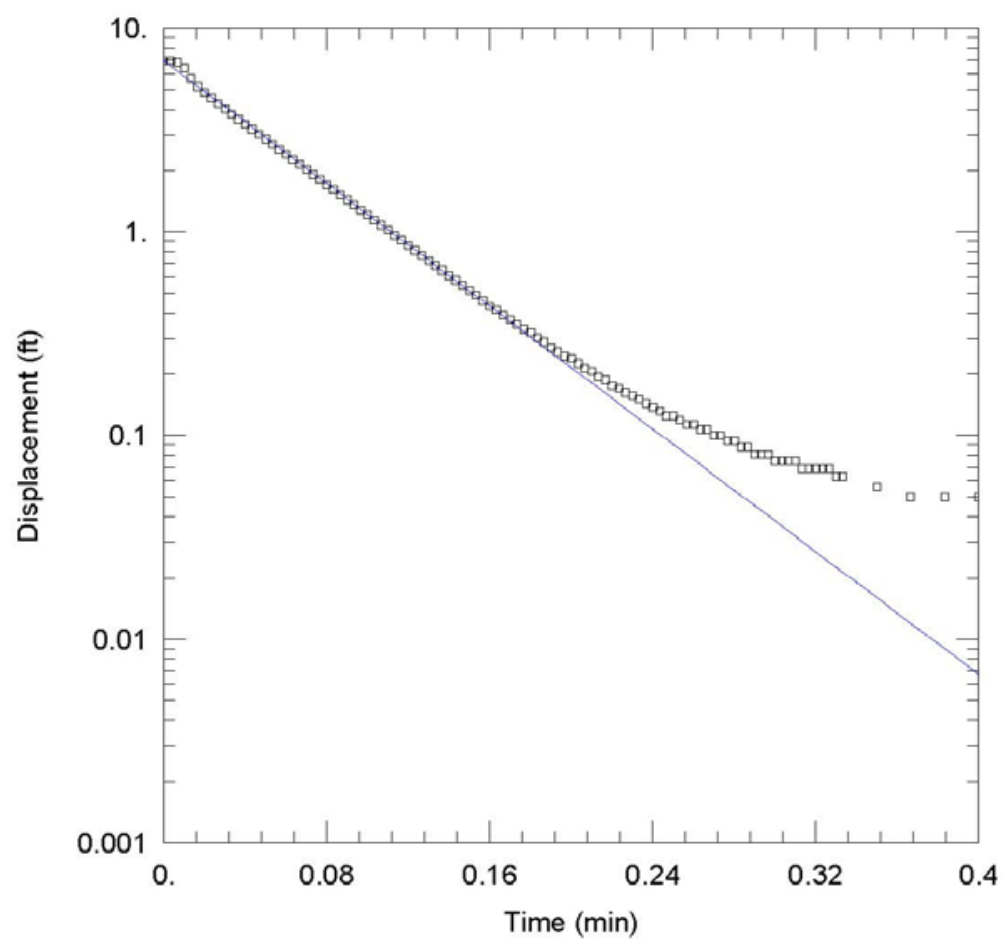

Observed slug test water level response and interpretive straight-line fit to the measured data for SB04 Test 1, Step 1.

FIGURE A.10 Observed slug test water level response and interpretive fit for the data for SB04 shown in Table A.10. 


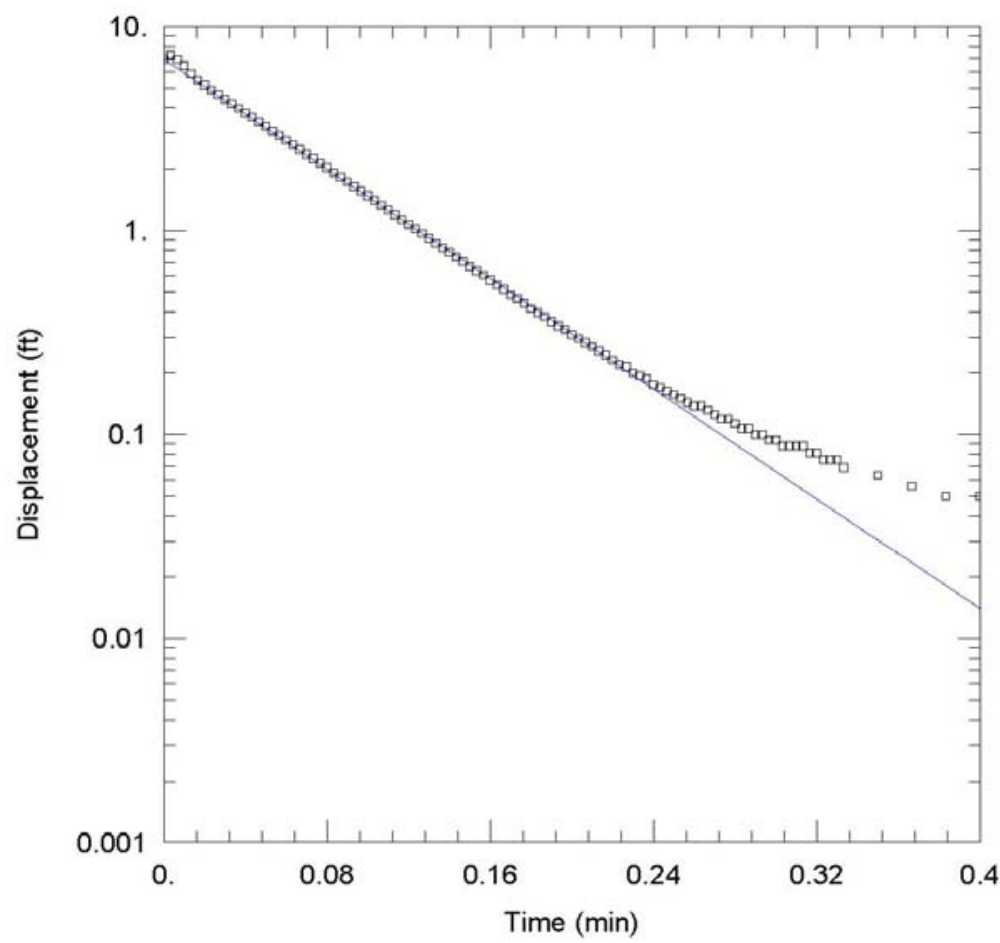

Observed slug test water level response and interpretive straight-line fit to the measured data for SB04 Test 1, Step 2.

FIGURE A.10 (Cont.) 


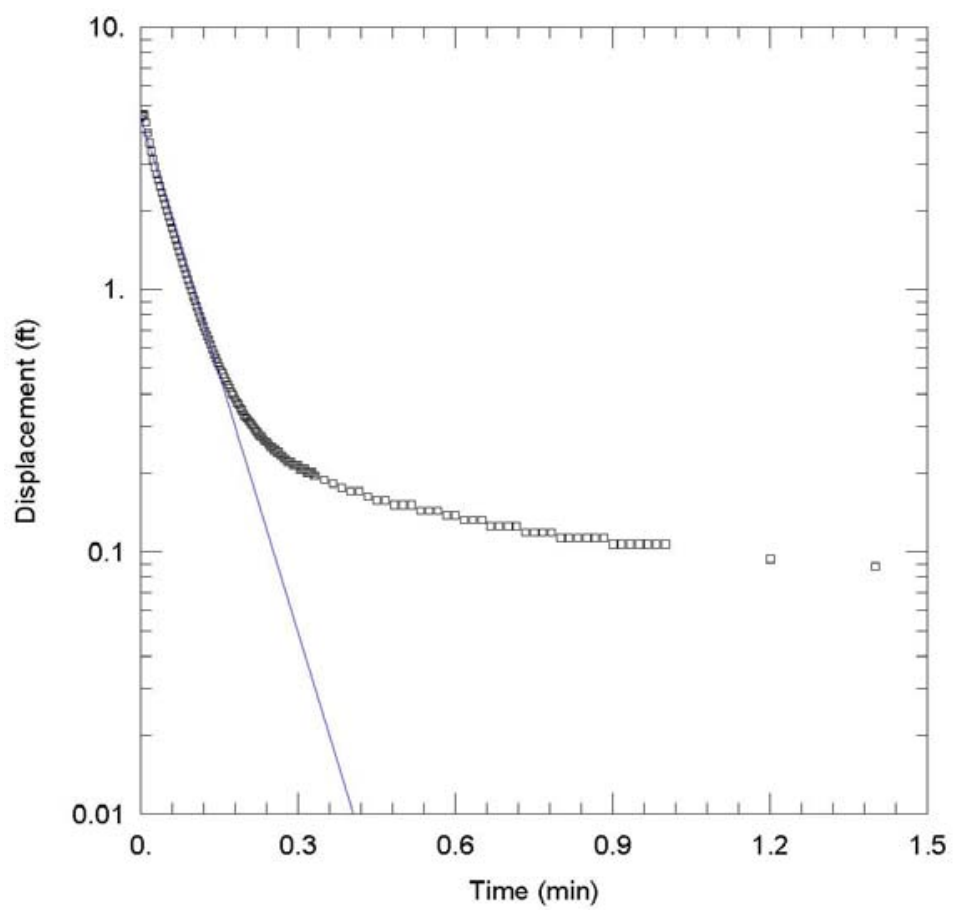

Observed slug test water level response and interpretive straight-line fit to the measured data for SB05 Test 5, Step 0.

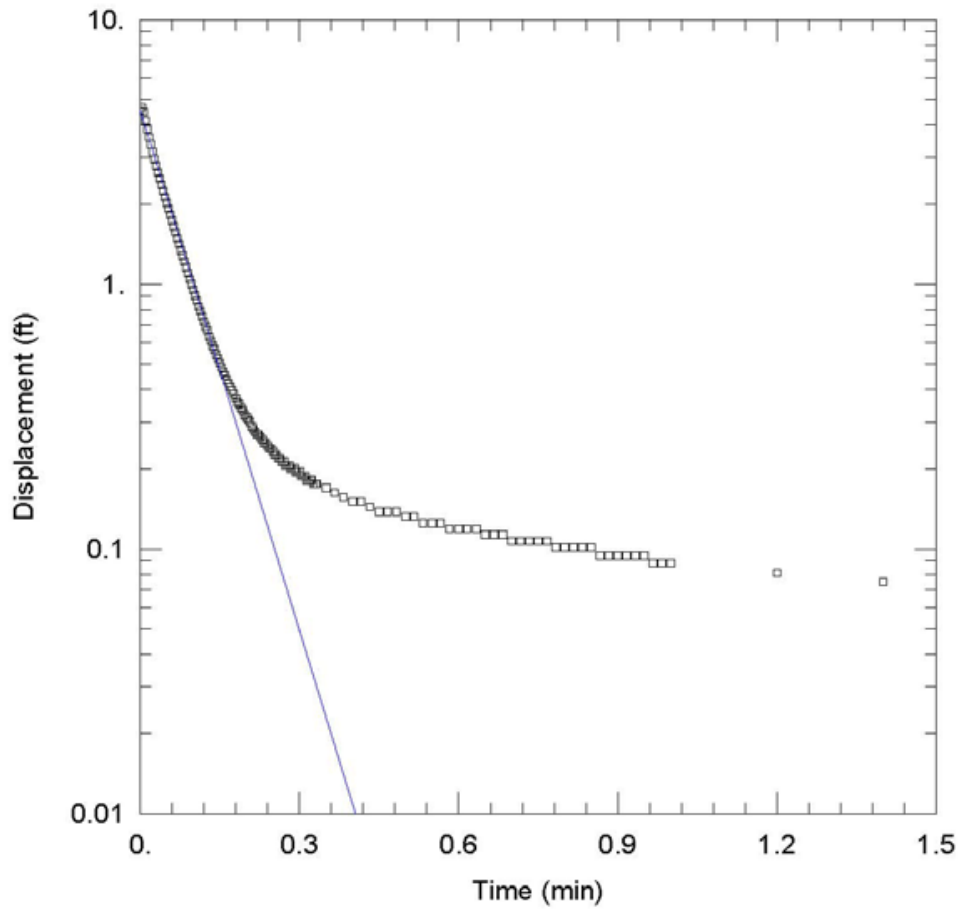

Observed slug test water level response and interpretive straight-line fit to the measured data for SB05 Test 5, Step 1.

FIGURE A.11 Observed slug test water level response and interpretive fit for the data for SB05 shown in Table A.11. 
Interim Remedial Measure for Centralia, Kansas: Conceptual Design and Pilot Test

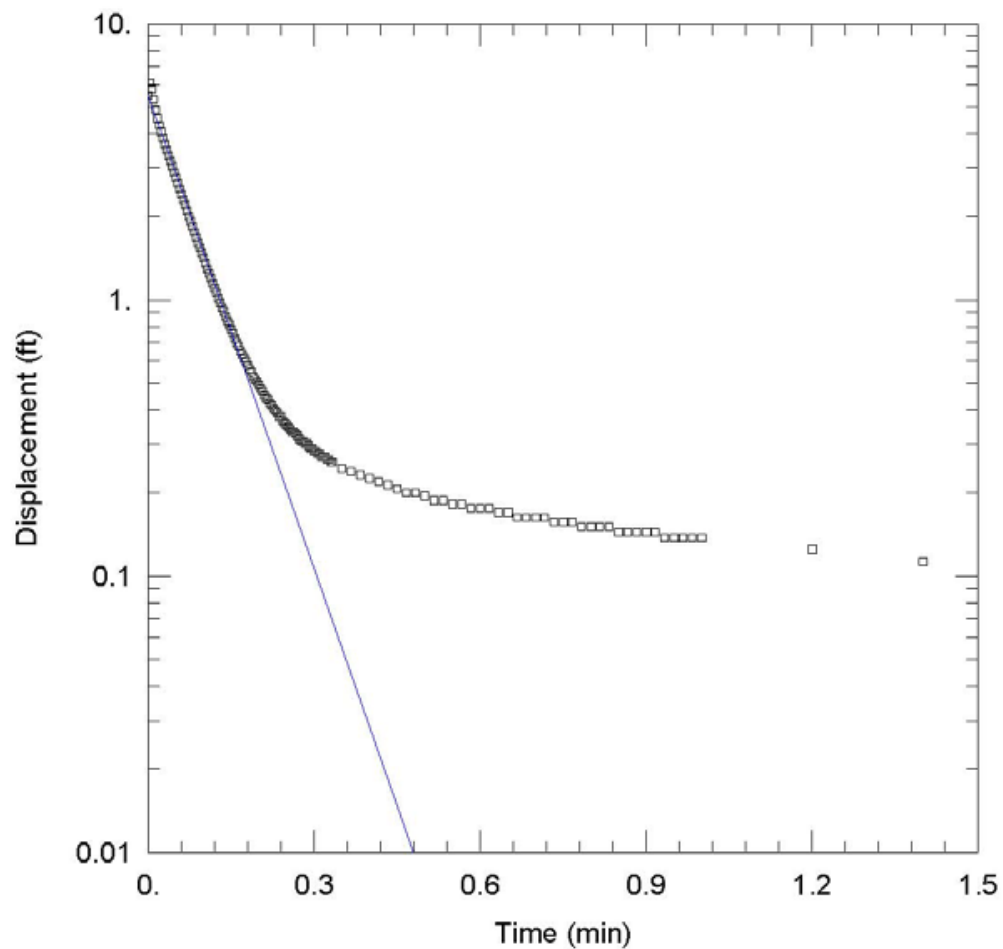

Observed slug test water level response and interpretive straight-line fit to the measured data for SB05 Test 5, Step 2.

FIGURE A.11 (Cont.) 


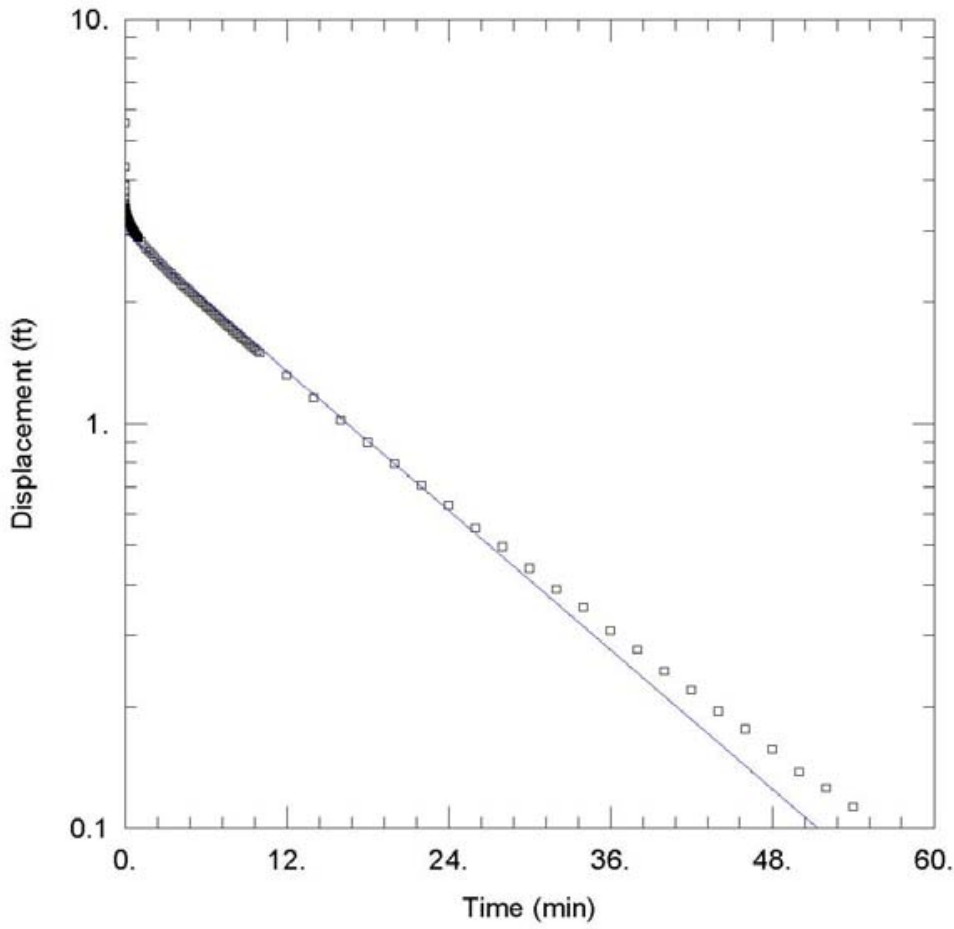

Observed slug test water level response and interpretive straightline fit to the measured data for SB07R Test 4, Step 0.

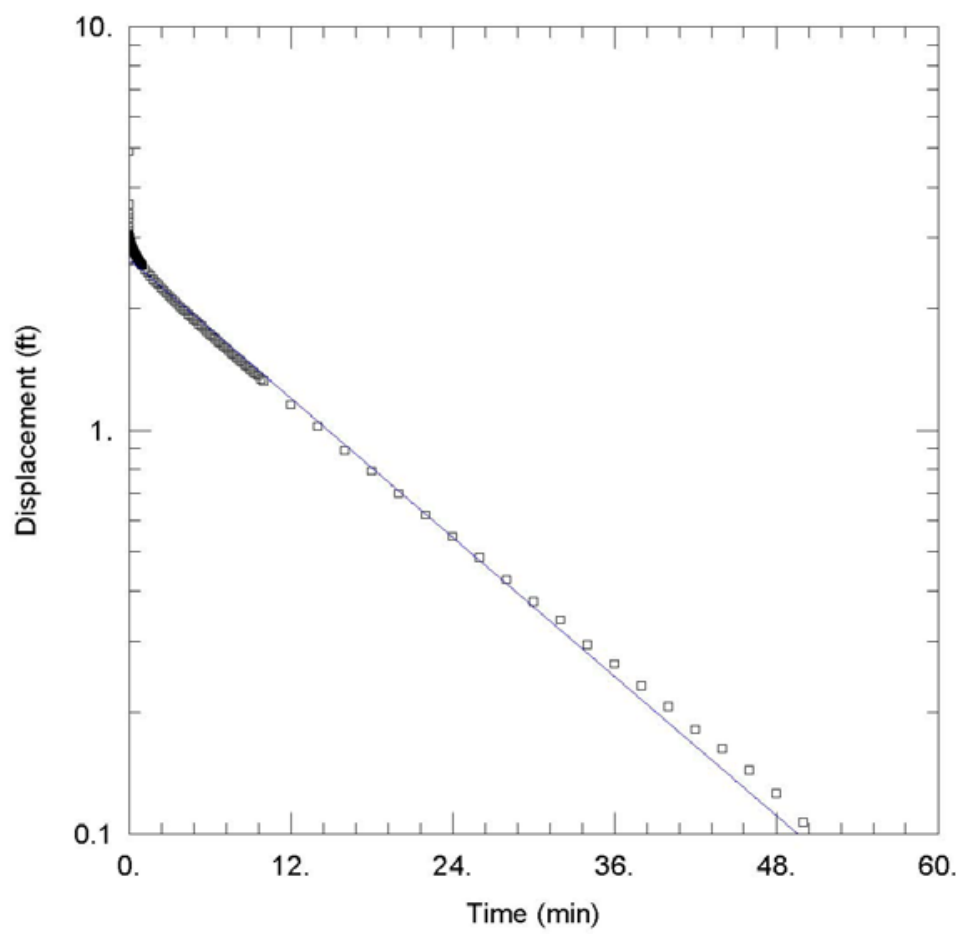

Observed slug test water level response and interpretive straightline fit to the measured data for SB07R Test 4, Step 1.

FIGURE A.12 Observed slug test water level response and interpretive fit for the data for SB07R shown in Table A.12. 


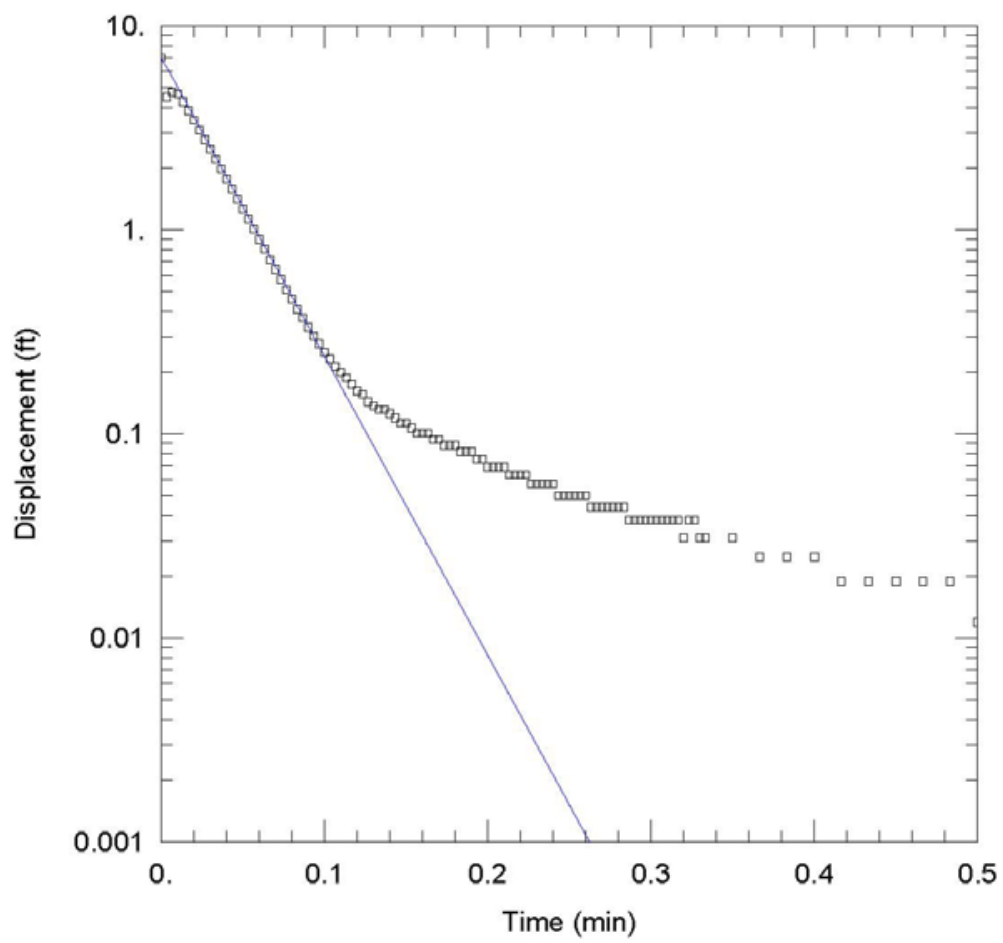

Observed slug test water level response and interpretive straight-line fit to the measured data for SB08 Test 3, Step 0.

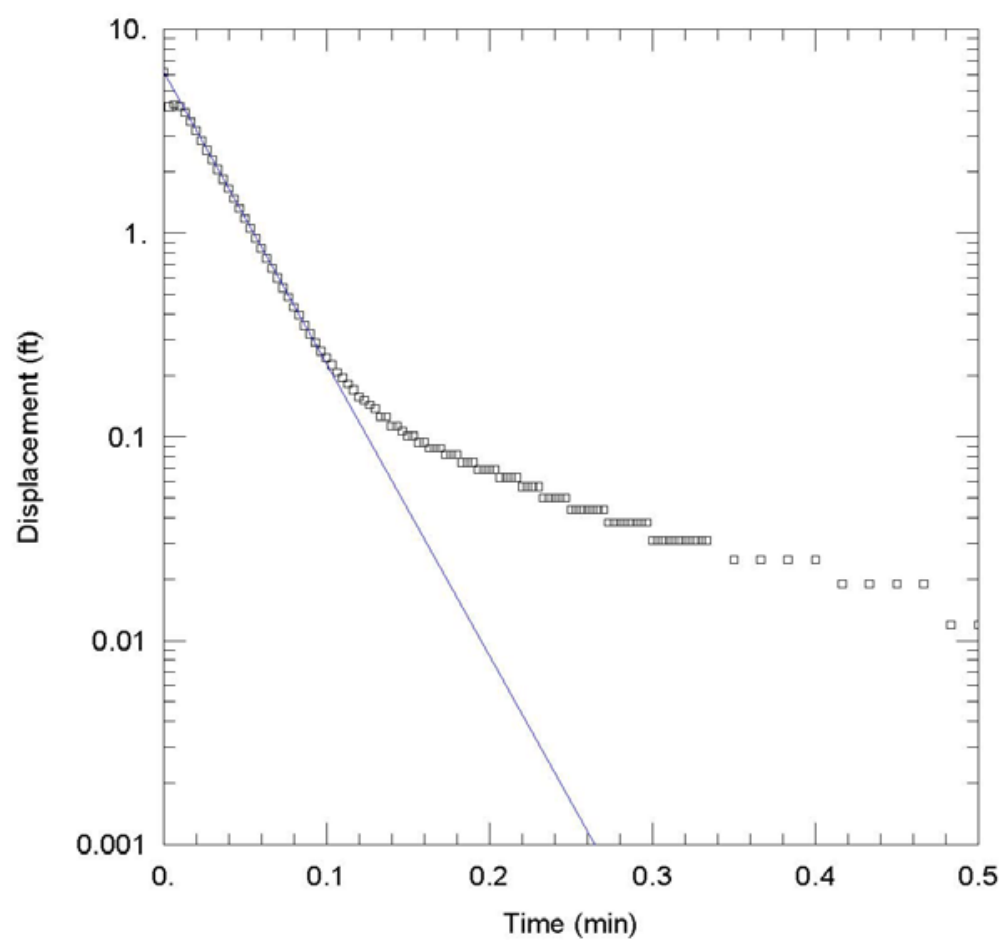

Observed slug test water level response and interpretive straight-line fit to the measured data for SB08 Test 3, Step 1.

FIGURE A.13 Observed slug test water level response and interpretive fit for the data for SB08 shown in Table A.13. 
Interim Remedial Measure for Centralia, Kansas: Conceptual Design and Pilot Test

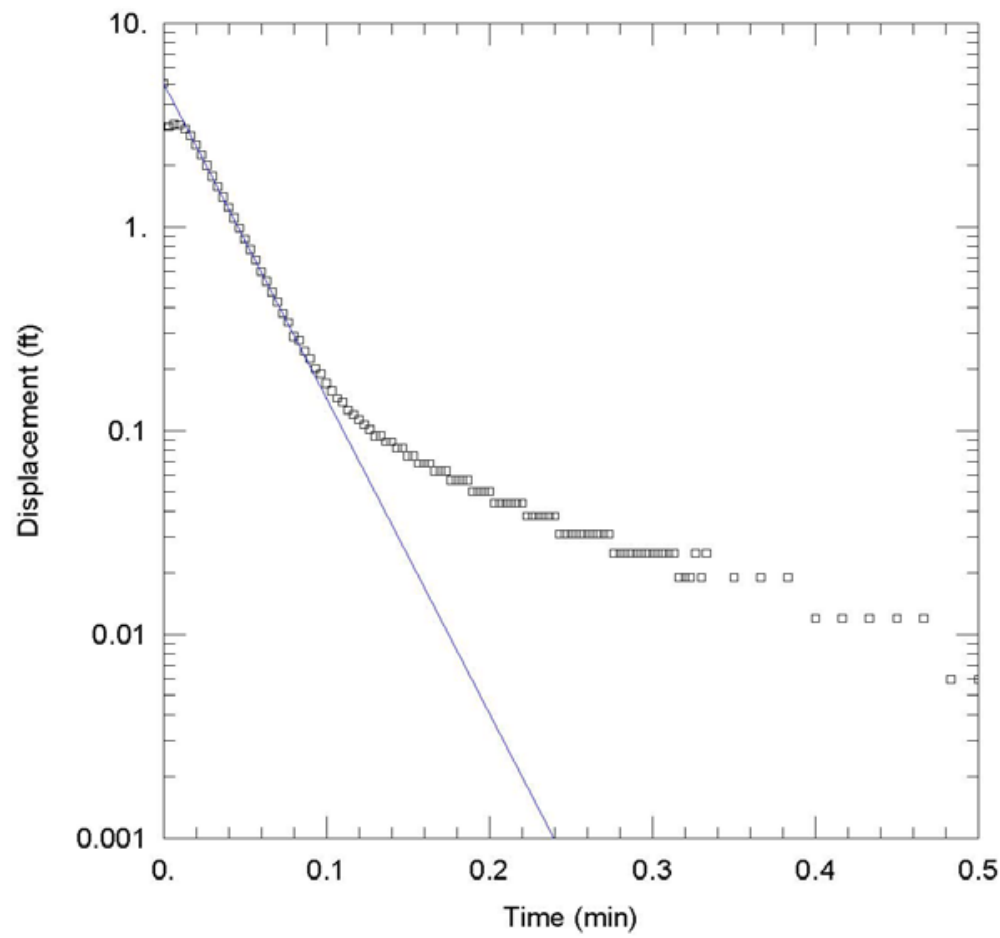

Observed slug test water level response and interpretive straightline fit to the measured data for SB08 Test 3, Step 2.

FIGURE A.13 (Cont.) 
TABLE A.1 Summary of interpreted results for slug tests at Centralia, Kansas

\begin{tabular}{|c|c|c|c|c|c|c|c|c|c|c|c|c|}
\hline \multirow[b]{2}{*}{ Location } & \multicolumn{2}{|c|}{ Diameter (in.) } & \multirow{2}{*}{$\begin{array}{l}\text { Reported } \\
\text { Well Deptha } \\
\text { (ft BGL) }\end{array}$} & \multirow{2}{*}{$\begin{array}{l}\text { Measured } \\
\text { Well Depth } \\
\text { (ft TOC) }\end{array}$} & \multirow{2}{*}{$\begin{array}{l}\text { Screen } \\
\text { Interval }^{\mathrm{a}} \\
\text { (ft BGL) }\end{array}$} & \multicolumn{6}{|c|}{ Calculated Hydraulic Conductivity ${ }^{\mathrm{c}}$ (ft/day) } & \multirow{2}{*}{$\begin{array}{c}\text { Estimated } \\
\text { Permeability } \\
\text { (darcy) }\end{array}$} \\
\hline & Casing & Hole & & & & \multicolumn{3}{|c|}{ Bouwer and Rice Method } & \multicolumn{3}{|c|}{ Hvorslev Method } & \\
\hline MW01 ${ }^{\mathrm{e}}$ & 4 & 11.5 & 67 & 69.55 & $54.5-64.5$ & 0.05 & & & 0.07 & & & $0.02-0.03$ \\
\hline MW02 & 4 & 11.5 & 62 & 61.32 & $49.5-59.5$ & 2.85 & 2.61 & 2.38 & 3.84 & 3.51 & 3.21 & $0.98-1.57$ \\
\hline MW04e & 4 & 11.5 & 50 & 49.25 & $37.5-47.5$ & 0.11 & 0.11 & & 0.14 & 0.14 & & $0.05-0.06$ \\
\hline MW06e & 4 & 11.5 & 65 & 60.03 & $46.5-56.5$ & 0.06 & 0.06 & & 0.09 & 0.08 & & $0.02-0.04$ \\
\hline MW07e & 2 & 8.25 & 60 & 58.47 & $45-55$ & 0.12 & 0.05 & & 0.16 & 0.06 & & $0.02-0.07$ \\
\hline MW08 & 2 & 8.25 & 58 & 57.41 & $38-53$ & 0.85 & 0.89 & 0.79 & 1.13 & 1.17 & 1.05 & $0.32-0.48$ \\
\hline MW10 & 2 & 8.25 & 50 & 47.73 & $30-45$ & 0.14 & 0.16 & 0.16 & 0.19 & 0.21 & 0.21 & $0.06-0.09$ \\
\hline $\mathrm{SB} 01^{\mathrm{e}}$ & 1 & 1.3 & 50 & 48.96 & $40-50$ & 0.001 & $<0.001$ & & 0.002 & $<0.001$ & & $<0.001$ \\
\hline SB04 & 1 & 1.3 & 61 & 59.16 & $51-61$ & 14.5 & 8.79 & 7.85 & 18.6 & 11.3 & 10.1 & $3.22-7.62$ \\
\hline SB05 & 1 & 1.3 & 42 & 40.82 & $32-42$ & 7.64 & 7.64 & 6.68 & 9.94 & 9.82 & 8.58 & $2.74-4.07$ \\
\hline SB07R & 2 & 8.25 & 60 & 58.54 & $45-60$ & 0.06 & 0.06 & & 0.08 & 0.08 & & $0.02-0.03$ \\
\hline SB08 & 1 & 1.3 & 62 & 59.80 & $52-62$ & 17.1 & 16.7 & 18.1 & 22.0 & 21.5 & 23.0 & $6.84-9.43$ \\
\hline
\end{tabular}

a Well parameters reported in construction logs and registrations.

b Well depth from top of casing, measured in September 2006.

c Caculated with the assumption that the effect of the slug test was dissipated over an aquifer thickness equal to the screen length.

d Intrinsic permeability estimated under the assumption of "pure" groundwater at the laboratory standard of $15.6^{\circ} \mathrm{C}$.

e Tests performed with a solid slug because of the long response time; all others were performed with the air pressurization method. 
TABLE A.2 Slug test data for boring MW01 (effective saturated thickness = $10 \mathrm{ft}$ : length of well $=10 \mathrm{ft}$; length of screen $=10 \mathrm{ft}$; casing radius $=0.1667 \mathrm{ft}$; borehole radius $=0.4792 \mathrm{ft}$; $\mathrm{Kz} / \mathrm{Kr}=1)$.

\begin{tabular}{|c|c|c|c|c|c|c|c|}
\hline $\begin{array}{c}\text { Elapsed } \\
\text { Time } \\
\text { (min) }\end{array}$ & $\begin{array}{l}\text { Residual } \\
\text { Drawdown } \\
\text { (ft) }\end{array}$ & $\begin{array}{l}\text { Elapsed } \\
\text { Time } \\
\text { (min) }\end{array}$ & $\begin{array}{c}\text { Residual } \\
\text { Drawdown } \\
(\mathrm{ft})\end{array}$ & $\begin{array}{l}\text { Elapsed } \\
\text { Time } \\
\text { (min) }\end{array}$ & $\begin{array}{c}\text { Residual } \\
\text { Drawdown } \\
(\mathrm{ft})\end{array}$ & $\begin{array}{l}\text { Elapsed } \\
\text { Time } \\
\text { (min) }\end{array}$ & $\begin{array}{l}\text { Residual } \\
\text { Drawdown } \\
\text { (ft) }\end{array}$ \\
\hline 0 & 1.869 & 0.1366 & 1.354 & 0.2733 & 1.344 & 0.7166 & 1.322 \\
\hline 0.0033 & 1.197 & 0.14 & 1.354 & 0.2766 & 1.344 & 0.7333 & 1.319 \\
\hline 0.0066 & 2.332 & 0.1433 & 1.357 & 0.28 & 1.348 & 0.75 & 1.319 \\
\hline 0.01 & 1.313 & 0.1466 & 1.354 & 0.2833 & 1.344 & 0.7666 & 1.319 \\
\hline 0.0133 & 0.75 & 0.15 & 1.354 & 0.2866 & 1.344 & 0.7833 & 1.319 \\
\hline 0.0166 & 1.278 & 0.1533 & 1.354 & 0.29 & 1.344 & 0.8 & 1.319 \\
\hline 0.02 & 1.612 & 0.1566 & 1.354 & 0.2933 & 1.348 & 0.8166 & 1.316 \\
\hline 0.0233 & 1.646 & 0.16 & 1.354 & 0.2966 & 1.344 & 0.8333 & 1.316 \\
\hline 0.0266 & 1.131 & 0.1633 & 1.354 & 0.3 & 1.344 & 0.85 & 1.316 \\
\hline 0.03 & 0.989 & 0.1666 & 1.354 & 0.3033 & 1.344 & 0.8666 & 1.313 \\
\hline 0.0333 & 1.423 & 0.17 & 1.357 & 0.3066 & 1.344 & 0.8833 & 1.313 \\
\hline 0.0366 & 1.527 & 0.1733 & 1.357 & 0.31 & 1.344 & 0.9 & 1.313 \\
\hline 0.04 & 1.37 & 0.1766 & 1.351 & 0.3133 & 1.344 & 0.9166 & 1.313 \\
\hline 0.0433 & 1.291 & 0.18 & 1.354 & 0.3166 & 1.344 & 0.9333 & 1.313 \\
\hline 0.0466 & 1.332 & 0.1833 & 1.354 & 0.32 & 1.341 & 0.95 & 1.31 \\
\hline 0.05 & 1.423 & 0.1866 & 1.354 & 0.3233 & 1.344 & 0.9666 & 1.31 \\
\hline 0.0533 & 1.379 & 0.19 & 1.351 & 0.3266 & 1.344 & 0.9833 & 1.31 \\
\hline 0.0566 & 1.332 & 0.1933 & 1.354 & 0.33 & 1.341 & 1 & 1.31 \\
\hline 0.06 & 1.357 & 0.1966 & 1.354 & 0.3333 & 1.344 & 1.2 & 1.297 \\
\hline 0.0633 & 1.379 & 0.2 & 1.351 & 0.35 & 1.341 & 1.4 & 1.291 \\
\hline 0.0666 & 1.373 & 0.2033 & 1.351 & 0.3666 & 1.341 & 1.6 & 1.285 \\
\hline 0.07 & 1.354 & 0.2066 & 1.354 & 0.3833 & 1.338 & 1.8 & 1.278 \\
\hline 0.0733 & 1.357 & 0.21 & 1.348 & 0.4 & 1.338 & 2 & 1.272 \\
\hline 0.0766 & 1.366 & 0.2133 & 1.354 & 0.4166 & 1.338 & 2.2 & 1.263 \\
\hline 0.08 & 1.363 & 0.2166 & 1.348 & 0.4333 & 1.338 & 2.4 & 1.26 \\
\hline 0.0833 & 1.357 & 0.22 & 1.351 & 0.45 & 1.335 & 2.6 & 1.253 \\
\hline 0.0866 & 1.357 & 0.2233 & 1.351 & 0.4666 & 1.335 & 2.8 & 1.247 \\
\hline 0.09 & 1.36 & 0.2266 & 1.348 & 0.4833 & 1.335 & 3 & 1.241 \\
\hline 0.0933 & 1.36 & 0.23 & 1.348 & 0.5 & 1.335 & 3.2 & 1.238 \\
\hline 0.0966 & 1.357 & 0.2333 & 1.348 & 0.5166 & 1.332 & 3.4 & 1.231 \\
\hline 0.1 & 1.357 & 0.2366 & 1.351 & 0.5333 & 1.332 & 3.6 & 1.228 \\
\hline 0.1033 & 1.354 & 0.24 & 1.348 & 0.55 & 1.332 & 3.8 & 1.222 \\
\hline 0.1066 & 1.357 & 0.2433 & 1.348 & 0.5666 & 1.329 & 4 & 1.216 \\
\hline 0.11 & 1.357 & 0.2466 & 1.348 & 0.5833 & 1.329 & 4.2 & 1.212 \\
\hline 0.1133 & 1.357 & 0.25 & 1.348 & 0.6 & 1.329 & 4.4 & 1.206 \\
\hline 0.1166 & 1.354 & 0.2533 & 1.348 & 0.6166 & 1.326 & 4.6 & 1.203 \\
\hline 0.12 & 1.36 & 0.2566 & 1.348 & 0.6333 & 1.326 & 4.8 & 1.2 \\
\hline 0.1233 & 1.363 & 0.26 & 1.344 & 0.65 & 1.326 & 5 & 1.194 \\
\hline 0.1266 & 1.36 & 0.2633 & 1.344 & 0.6666 & 1.326 & 5.2 & 1.19 \\
\hline 0.13 & 1.357 & 0.2666 & 1.348 & 0.6833 & 1.322 & 5.4 & 1.187 \\
\hline 0.1333 & 1.357 & 0.27 & 1.348 & 0.7 & 1.322 & 5.6 & 1.181 \\
\hline
\end{tabular}


Interim Remedial Measure for Centralia, Kansas: Conceptual Design and Pilot Test Version 00, 08/30/07

TABLE A.2 (Cont.)

\begin{tabular}{|c|c|c|c|c|c|}
\hline $\begin{array}{c}\text { Elapsed } \\
\text { Time } \\
\text { (min) }\end{array}$ & $\begin{array}{c}\text { Residual } \\
\text { Drawdown } \\
(\mathrm{ft})\end{array}$ & $\begin{array}{c}\text { Elapsed } \\
\text { Time } \\
\text { (min) }\end{array}$ & $\begin{array}{c}\text { Residual } \\
\text { Drawdown } \\
(\mathrm{ft})\end{array}$ & $\begin{array}{l}\text { Elapsed } \\
\text { Time } \\
\text { (min) }\end{array}$ & $\begin{array}{c}\text { Residual } \\
\text { Drawdown } \\
\text { (ft) }\end{array}$ \\
\hline 5.8 & 1.178 & 54 & 0.716 & 300 & 0.361 \\
\hline 6 & 1.175 & 56 & 0.706 & 310 & 0.361 \\
\hline 6.2 & 1.172 & 58 & 0.694 & 320 & 0.361 \\
\hline 6.4 & 1.168 & 60 & 0.684 & 330 & 0.357 \\
\hline 6.6 & 1.162 & 62 & 0.675 & 340 & 0.357 \\
\hline 6.8 & 1.159 & 64 & 0.665 & 350 & 0.357 \\
\hline 7 & 1.156 & 66 & 0.656 & 360 & 0.357 \\
\hline 7.2 & 1.153 & 68 & 0.647 & 370 & 0.357 \\
\hline 7.4 & 1.15 & 70 & 0.64 & 380 & 0.357 \\
\hline 7.6 & 1.143 & 72 & 0.631 & 390 & 0.357 \\
\hline 7.8 & 1.14 & 74 & 0.621 & 400 & 0.357 \\
\hline 8 & 1.137 & 76 & 0.615 & 410 & 0.357 \\
\hline 8.2 & 1.134 & 78 & 0.606 & 420 & 0.357 \\
\hline 8.4 & 1.131 & 80 & 0.599 & 430 & 0.357 \\
\hline 8.6 & 1.128 & 82 & 0.593 & 440 & 0.357 \\
\hline 8.8 & 1.124 & 84 & 0.587 & & \\
\hline 9 & 1.121 & 86 & 0.577 & & \\
\hline 9.2 & 1.118 & 88 & 0.571 & & \\
\hline 9.4 & 1.115 & 90 & 0.565 & & \\
\hline 9.6 & 1.112 & 92 & 0.562 & & \\
\hline 9.8 & 1.109 & 94 & 0.555 & & \\
\hline 10 & 1.106 & 96 & 0.549 & & \\
\hline 12 & 1.077 & 98 & 0.543 & & \\
\hline 14 & 1.049 & 100 & 0.537 & & \\
\hline 16 & 1.024 & 110 & 0.511 & & \\
\hline 18 & 0.999 & 120 & 0.493 & & \\
\hline 20 & 0.977 & 130 & 0.471 & & \\
\hline 22 & 0.955 & 140 & 0.455 & & \\
\hline 24 & 0.936 & 150 & 0.442 & & \\
\hline 26 & 0.917 & 160 & 0.43 & & \\
\hline 28 & 0.898 & 170 & 0.42 & & \\
\hline 30 & 0.882 & 180 & 0.411 & & \\
\hline 32 & 0.864 & 190 & 0.401 & & \\
\hline 34 & 0.848 & 200 & 0.392 & & \\
\hline 36 & 0.832 & 210 & 0.389 & & \\
\hline 38 & 0.819 & 220 & 0.383 & & \\
\hline 40 & 0.804 & 230 & 0.379 & & \\
\hline 42 & 0.791 & 240 & 0.373 & & \\
\hline 44 & 0.779 & 250 & 0.37 & & \\
\hline 46 & 0.763 & 260 & 0.37 & & \\
\hline 48 & 0.75 & 270 & 0.367 & & \\
\hline 50 & 0.738 & 280 & 0.364 & & \\
\hline 52 & 0.725 & 290 & 0.364 & & \\
\hline
\end{tabular}


TABLE A.3 Slug test data for boring MW02 (effective saturated thickness $=10 \mathrm{ft}$ : length of well $=$ $10 \mathrm{ft}$; length of screen $=10 \mathrm{ft}$; casing radius $=0.1667 \mathrm{ft}$; borehole radius $=0.4792 \mathrm{ft} ; \mathrm{Kz} / \mathrm{Kr}=1$ ).

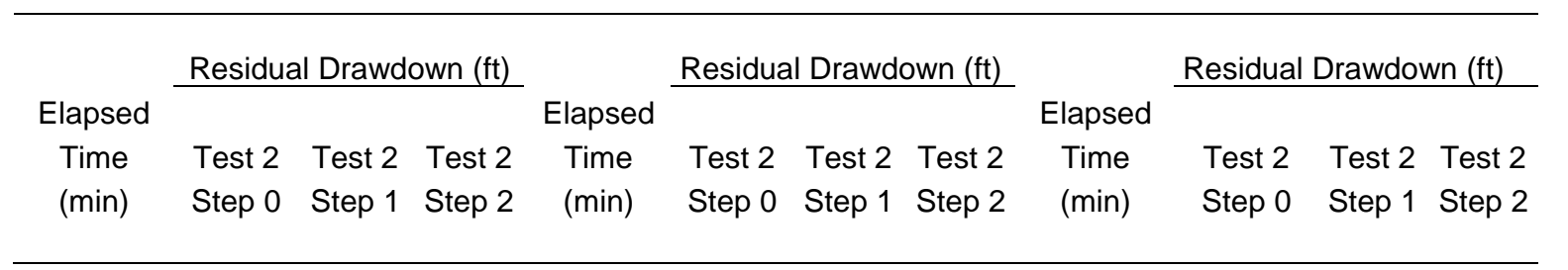

\begin{tabular}{|c|c|c|c|c|c|c|c|c|c|c|c|}
\hline 0 & 7.652 & 8.847 & 6.633 & 0.1366 & 6.834 & 8.413 & 6.765 & 0.2733 & 6.362 & 8.036 & 6.488 \\
\hline 0.0033 & 7.293 & 8.621 & 7.281 & 0.14 & 6.821 & 8.401 & 6.759 & 0.2766 & 6.35 & 8.03 & 6.482 \\
\hline .0066 & 7.457 & 8.954 & 7.218 & 0.1433 & 6.809 & 8.388 & 6.746 & 0.28 & .337 & 8.023 & 6.482 \\
\hline 0.01 & 7.532 & 8.973 & 6.928 & 0.1466 & 6.796 & 8.382 & 6.74 & 0.2833 & 3.331 & 8.017 & 0.469 \\
\hline 0.0133 & 7.319 & 8.785 & 7.054 & 0.15 & 6.79 & 8.376 & 6.733 & 0.2866 & 3.318 & 8.004 & 6.463 \\
\hline 0.0166 & 7.319 & 8.728 & 7.117 & 0.1533 & 6.777 & 8.363 & 6.727 & 0.29 & 6.305 & 7.992 & 6.457 \\
\hline 0.02 & 7.4 & 8.829 & 6.985 & 0.1566 & 6.765 & 8.35 & 6.714 & 0.2933 & 6.299 & 7.985 & 6.45 \\
\hline .0233 & 7.337 & 8.822 & 6.991 & 0.16 & 6.752 & 8.344 & 6.714 & 0.2966 & 6.287 & 7.979 & 6.444 \\
\hline 0.0266 & 7.281 & 8.759 & 7.054 & 0.1633 & 6.74 & 8.332 & 6.708 & 0.3 & 6.274 & 7.967 & 6.438 \\
\hline 0.03 & 7.3 & 8.741 & 6.998 & 0.1666 & 6.727 & 8.319 & 6.696 & 0.3033 & 6.268 & 7.96 & 6.431 \\
\hline 0.0333 & 7.281 & 8.759 & 6.972 & 0.17 & 6.714 & 8.319 & 6.689 & 0.3066 & 6.255 & 7.948 & 6.425 \\
\hline .0366 & 7.237 & 8.734 & 6.998 & 0.1733 & 6.702 & 8.306 & 6.683 & 0.31 & 0.243 & 7.941 & 6.419 \\
\hline 0.04 & 7.237 & 8.709 & 6.985 & 0.1766 & 6.689 & 8.294 & 6.683 & 0.3133 & 6.236 & 7.935 & 6.412 \\
\hline 0.0433 & 7.23 & 8.696 & 6.96 & 0.18 & 6.677 & 8.287 & 6.67 & 0.3166 & 6.224 & 7.923 & 6.406 \\
\hline 0.0466 & 7.205 & 8.696 & 6.966 & 0.1833 & 6.67 & 8.281 & 6.664 & 0.32 & 6.211 & 7.916 & 6.4 \\
\hline 0.05 & 7.18 & 8.684 & 6.96 & 0.1866 & 6.658 & 8.269 & 6.658 & 0.3233 & 6.205 & 7.91 & 6.394 \\
\hline 0.0533 & 7.18 & 8.671 & 6.941 & 0.19 & 6.645 & 8.262 & 6.652 & 0.3266 & 192 & 7.897 & 6.387 \\
\hline 0.0566 & 7.161 & 8.646 & 6.941 & 0.1933 & 6.633 & 8.25 & 6.645 & 0.33 & 0.18 & 7.891 & 6.381 \\
\hline 0.06 & 7.136 & 8.646 & 6.935 & 0.1966 & 6.62 & 8.243 & 6.639 & 0.3333 & 6.167 & 7.879 & 6.375 \\
\hline 0.0633 & 7.124 & 8.634 & 6.916 & 0.2 & 6.614 & 8.231 & 6.633 & 0.35 & 6.117 & 7.841 & 6.343 \\
\hline 0.0666 & 7.117 & 8.621 & 6.916 & 0.2033 & 6.601 & 8.225 & 6.626 & 0.3666 & 6.066 & 7.797 & 6.312 \\
\hline 0.07 & 7.098 & 8.621 & 6.91 & 0.2066 & 6.589 & 8.218 & 6.62 & 0.3833 & 6.016 & 7.759 & 6.28 \\
\hline 0.0733 & 7.086 & 8.602 & 6.897 & 0.21 & 6.576 & 8.206 & 6.614 & 0.4 & 5.966 & 7.715 & 6.255 \\
\hline 0.0766 & 7.073 & 8.596 & 6.891 & 0.2133 & 6.563 & 8.199 & 6.607 & 0.4166 & 5.915 & 7.677 & 6.224 \\
\hline 0.08 & 7.054 & 8.577 & 6.884 & 0.2166 & 6.551 & 8.187 & 6.601 & 0.4333 & 5.865 & 7.633 & 6.192 \\
\hline 0.0833 & 7.042 & 8.571 & 6.878 & 0.22 & 6.538 & 8.181 & 6.595 & 0.45 & 5.815 & 7.595 & 6.161 \\
\hline 0.0866 & 7.035 & 8.558 & 6.866 & 0.2233 & 6.532 & 8.168 & 6.589 & 0.4666 & 5.771 & 7.551 & 6.136 \\
\hline 0.09 & 7.01 & 8.552 & 6.859 & 0.2266 & 6.519 & 8.162 & 6.576 & 0.4833 & 5.72 & 7.514 & 6.104 \\
\hline 0.0933 & 6.998 & 8.539 & 6.853 & 0.23 & 6.507 & 8.155 & 6.57 & 0.5 & 5.67 & 7.476 & 6.073 \\
\hline 0.0966 & 6.991 & 8.527 & 6.847 & 0.2333 & 6.501 & 8.143 & 6.57 & 0.5166 & 5.626 & 7.432 & 6.047 \\
\hline 0.1 & 6.972 & 8.52 & 6.84 & 0.2366 & 6.482 & 8.137 & 6.557 & 0.5333 & 5.576 & 7.394 & 6.016 \\
\hline 0.1033 & 6.966 & 8.508 & 6.834 & 0.24 & 6.475 & 8.13 & 6.551 & 0.55 & 5.531 & 7.356 & 5.985 \\
\hline 0.1066 & 6.947 & 8.495 & 6.828 & 0.2433 & 6.457 & 8.118 & 6.545 & 0.5666 & 5.481 & 7.312 & 5.959 \\
\hline 0.11 & 6.935 & 8.489 & 6.815 & 0.2466 & 6.45 & 8.105 & 6.545 & 0.5833 & 5.437 & 7.274 & 5.928 \\
\hline 0.1133 & 6.922 & 8.476 & 6.809 & 0.25 & 6.444 & 8.099 & 6.538 & 0.6 & 5.393 & 7.237 & 5.896 \\
\hline 0.1166 & 6.91 & 8.47 & 6.803 & 0.2533 & 6.431 & 8.092 & 6.526 & 0.6166 & 5.349 & 7.199 & 5.871 \\
\hline 0.12 & 6.897 & 8.457 & 6.803 & 0.2566 & 6.419 & 8.08 & 6.519 & 0.6333 & 5.305 & 7.161 & 5.84 \\
\hline 0.1233 & 6.884 & 8.451 & 6.79 & 0.26 & 6.406 & 8.074 & 6.519 & 0.65 & 5.255 & 7.124 & 5.815 \\
\hline 0.1266 & 6.872 & 8.438 & 6.777 & 0.2633 & 6.394 & 8.067 & 6.507 & 0.6666 & 5.217 & 7.086 & 5.783 \\
\hline 0.13 & 6.859 & 8.426 & 6.771 & 0.2666 & 6.387 & 8.048 & 6.501 & 0.6833 & 5.173 & 7.048 & 5.758 \\
\hline 0.1333 & 6.847 & 8.42 & 6.771 & 0.27 & 6.375 & 8.042 & 6.494 & 0.7 & 5.129 & 7.01 & 5.727 \\
\hline
\end{tabular}


TABLE A.3 (Cont.)

\begin{tabular}{|c|c|c|c|c|c|c|c|}
\hline \multirow{2}{*}{$\begin{array}{c}\text { Elapsed } \\
\text { Time } \\
\text { (min) }\end{array}$} & \multicolumn{3}{|c|}{ Residual Drawdown (ft) } & \multirow{2}{*}{$\begin{array}{c}\text { Elapsed } \\
\text { Time } \\
\text { (min) }\end{array}$} & \multicolumn{3}{|c|}{ Residual Drawdown (ft) } \\
\hline & $\begin{array}{l}\text { Test } 2 \\
\text { Step } 0\end{array}$ & $\begin{array}{l}\text { Test } 2 \\
\text { Step } 1\end{array}$ & $\begin{array}{l}\text { Test } 2 \\
\text { Step } 2\end{array}$ & & $\begin{array}{l}\text { Test } 2 \\
\text { Step } 0\end{array}$ & $\begin{array}{l}\text { Test } 2 \\
\text { Step } 1\end{array}$ & $\begin{array}{l}\text { Test } 2 \\
\text { Step } 2\end{array}$ \\
\hline 0.7166 & 5.085 & 6.972 & 5.701 & 4 & 0.686 & 2.001 & 1.869 \\
\hline 0.7333 & 5.041 & 6.935 & 5.67 & 4.2 & 0.591 & 1.825 & 1.73 \\
\hline 0.75 & 4.997 & 6.897 & 5.645 & 4.4 & 0.509 & 1.667 & 1.592 \\
\hline 0.7666 & 4.959 & 6.859 & 5.62 & 4.6 & 0.44 & 1.516 & 1.466 \\
\hline 0.7833 & 4.915 & 6.821 & 5.588 & 4.8 & 0.377 & 1.372 & 1.346 \\
\hline 0.8 & 4.871 & 6.784 & 5.563 & 5 & 0.327 & 1.24 & 1.233 \\
\hline 0.8166 & 4.833 & 6.746 & 5.538 & 5.2 & 0.276 & 1.12 & 1.133 \\
\hline 0.8333 & 4.789 & 6.708 & 5.506 & 5.4 & 0.239 & 1.013 & 1.032 \\
\hline 0.85 & 4.751 & 6.677 & 5.481 & 5.6 & 0.207 & 0.906 & 0.944 \\
\hline 0.8666 & 4.707 & 6.639 & 5.456 & 5.8 & 0.176 & 0.818 & 0.862 \\
\hline 0.8833 & 4.669 & 6.601 & 5.425 & 6 & 0.151 & 0.73 & 0.78 \\
\hline 0.9 & 4.632 & 6.563 & 5.399 & 6.2 & 0.132 & 0.654 & 0.711 \\
\hline 0.9166 & 4.594 & 6.532 & 5.374 & 6.4 & 0.113 & 0.585 & 0.642 \\
\hline 0.9333 & 4.55 & 6.494 & 5.349 & 6.6 & 0.1 & 0.516 & 0.585 \\
\hline 0.95 & 4.512 & 6.457 & 5.324 & 6.8 & 0.088 & 0.459 & 0.528 \\
\hline 0.9666 & 4.474 & 6.425 & 5.299 & 7 & 0.075 & 0.409 & 0.472 \\
\hline 0.9833 & 4.437 & 6.387 & 5.267 & 7.2 & 0.069 & 0.365 & 0.428 \\
\hline 1 & 4.399 & 6.356 & 5.242 & 7.4 & 0.056 & 0.321 & 0.384 \\
\hline 1.2 & 3.99 & 5.985 & 4.94 & 7.6 & 0.05 & 0.283 & 0.346 \\
\hline 1.4 & 3.587 & 5.588 & 4.644 & 7.8 & 0.05 & 0.251 & 0.308 \\
\hline 1.6 & 3.216 & 5.217 & 4.361 & 8 & 0.044 & 0.226 & 0.276 \\
\hline 1.8 & 2.876 & 4.858 & 4.09 & 8.2 & 0.037 & 0.195 & 0.251 \\
\hline 2 & 2.567 & 4.525 & 3.839 & 8.4 & 0.031 & 0.176 & 0.226 \\
\hline 2.2 & 2.278 & 4.204 & 3.593 & 8.6 & 0.031 & 0.157 & 0.201 \\
\hline 2.4 & 2.02 & 3.895 & 3.36 & 8.8 & 0.031 & 0.138 & 0.176 \\
\hline 2.6 & 1.781 & 3.612 & 3.134 & 9 & 0.025 & 0.119 & 0.157 \\
\hline 2.8 & 1.567 & 3.335 & 2.926 & 9.2 & 0.025 & 0.107 & 0.144 \\
\hline 3 & 1.378 & 3.077 & 2.725 & 9.4 & 0.025 & 0.094 & 0.125 \\
\hline 3.2 & 1.208 & 2.838 & 2.53 & 9.6 & 0.018 & 0.081 & 0.113 \\
\hline 3.4 & 1.051 & 2.612 & 2.354 & 9.8 & 0.018 & 0.075 & 0.1 \\
\hline 3.6 & 0.919 & 2.391 & 2.184 & 10 & 0.018 & 0.069 & 0.088 \\
\hline 3.8 & 0.793 & 2.19 & 2.02 & 12 & & 0.025 & 0.031 \\
\hline
\end{tabular}


TABLE A.4 Slug test data for boring MW04 (effective saturated thickness = $10 \mathrm{ft}$ : length of well $=10 \mathrm{ft}$; length of screen $=10 \mathrm{ft}$; casing radius $=0.1667 \mathrm{ft}$; borehole radius $=0.4792 \mathrm{ft}$; $\mathrm{Kz} / \mathrm{Kr}=1)$.

\begin{tabular}{|c|c|c|c|c|c|c|c|c|}
\hline \multirow{2}{*}{$\begin{array}{l}\text { Elapsed } \\
\text { Time } \\
\text { (min) }\end{array}$} & \multicolumn{2}{|c|}{$\begin{array}{c}\text { Residual } \\
\text { Drawadown (ft) }\end{array}$} & \multirow{2}{*}{$\begin{array}{c}\text { Elapsed } \\
\text { Time } \\
\text { (min) }\end{array}$} & \multicolumn{2}{|c|}{$\begin{array}{c}\text { Residual } \\
\text { Drawadown (ft) }\end{array}$} & \multirow{2}{*}{$\begin{array}{c}\text { Elapsed } \\
\text { Time } \\
\text { (min) }\end{array}$} & \multicolumn{2}{|c|}{$\begin{array}{c}\text { Residual } \\
\text { Drawadown (ft) }\end{array}$} \\
\hline & $\begin{array}{l}\text { Slug } \\
\text { In }\end{array}$ & $\begin{array}{l}\text { Slug } \\
\text { Out }\end{array}$ & & $\begin{array}{l}\text { Slug } \\
\text { In }\end{array}$ & $\begin{array}{l}\text { Slug } \\
\text { Out }\end{array}$ & & $\underset{\text { Slug }}{\text { Sln }}$ & $\begin{array}{l}\text { Slug } \\
\text { Out }\end{array}$ \\
\hline 0 & 0 & 0 & 0.3147 & 1.148 & 1.161 & 3.1297 & 1.053 & 1.063 \\
\hline 0.005 & 0.009 & 0.002 & 0.3333 & 1.148 & 1.16 & 3.3163 & 1.046 & 1.058 \\
\hline 0.01 & 0.011 & & 0.3532 & 1.146 & 1.158 & 3.5147 & 1.041 & 1.051 \\
\hline 0.015 & 0.013 & 0.006 & 0.3742 & 1.145 & 1.157 & 3.7247 & 1.037 & 1.046 \\
\hline 0.02 & 0.014 & 0.003 & 0.3963 & 1.144 & 1.157 & 3.9463 & 1.029 & 1.039 \\
\hline 0.025 & 0.859 & & 0.4198 & 1.142 & 1.155 & 4.1813 & 1.025 & 1.033 \\
\hline 0.03 & 1.041 & 0.033 & 0.4447 & 1.141 & 1.155 & 4.4295 & 1.017 & 1.027 \\
\hline 0.035 & 1.157 & & 0.4697 & 1.14 & 1.153 & 4.693 & 1.009 & 1.038 \\
\hline 0.04 & 0.917 & 0.004 & 0.4963 & 1.138 & 1.153 & 4.973 & 1.002 & 1.008 \\
\hline 0.045 & 1.616 & & 0.5247 & 1.137 & 1.151 & 5.2697 & 0.995 & 1 \\
\hline 0.05 & 1.407 & 0.053 & 0.5547 & 1.135 & 1.148 & 5.583 & 0.986 & 0.993 \\
\hline 0.055 & 1.319 & 0.489 & 0.5863 & 1.134 & 1.148 & 5.9147 & 0.979 & 0.981 \\
\hline 0.06 & 0.513 & & 0.6213 & 1.134 & 1.147 & 6.2663 & 0.97 & 0.971 \\
\hline 0.065 & 1.539 & 0.293 & 0.6578 & 1.13 & 1.146 & 6.6397 & 0.961 & 0.963 \\
\hline 0.07 & 0.9 & & 0.6963 & 1.13 & 1.144 & 7.0347 & 0.951 & 0.951 \\
\hline 0.075 & 1.345 & 2.048 & 0.738 & 1.127 & 1.143 & 7.453 & 0.94 & 0.942 \\
\hline 0.08 & 1.035 & & 0.7813 & 1.126 & 1.141 & 7.8963 & 0.93 & 0.933 \\
\hline 0.0848 & 1.362 & 0.946 & 0.828 & 1.125 & 1.138 & 8.3663 & 0.919 & 0.919 \\
\hline 0.09 & 1.11 & 1.243 & 0.8763 & 1.123 & 1.136 & 8.8647 & 0.908 & 0.908 \\
\hline 0.095 & 0.978 & 0.966 & 0.928 & 1.121 & 1.134 & 9.3913 & 0.895 & 0.901 \\
\hline 0.1 & 1.26 & 1.482 & 0.983 & 1.119 & 1.133 & 9.9497 & 0.883 & 0.888 \\
\hline 0.1058 & 1.149 & 1.081 & 1.0413 & 1.118 & 1.131 & 10.5413 & 0.871 & 0.874 \\
\hline 0.112 & 1.159 & 1.058 & 1.103 & 1.114 & 1.129 & 11.168 & 0.858 & 0.86 \\
\hline 0.1185 & 1.238 & 1.215 & 1.168 & 1.112 & 1.126 & 11.8313 & 0.843 & 0.846 \\
\hline 0.1255 & 1.156 & 1.246 & 1.238 & 1.111 & 1.124 & 12.5347 & 0.83 & 0.831 \\
\hline 0.1328 & 1.145 & 1.226 & 1.3113 & 1.108 & 1.121 & 13.2797 & 0.815 & 0.818 \\
\hline 0.1407 & 1.168 & 1.204 & 1.3897 & 1.106 & 1.119 & 14.0697 & 0.8 & 0.802 \\
\hline 0.149 & 1.178 & 1.193 & 1.473 & 1.104 & 1.115 & 14.9063 & 0.784 & 0.785 \\
\hline 0.1578 & 1.175 & 1.198 & 1.5613 & 1.1 & 1.112 & 15.7913 & 0.766 & 0.769 \\
\hline 0.167 & 1.164 & 1.198 & 1.6547 & 1.097 & 1.11 & 16.7297 & 0.75 & 0.751 \\
\hline 0.177 & 1.162 & 1.199 & 1.753 & 1.095 & 1.105 & 17.723 & 0.732 & 0.734 \\
\hline 0.1875 & 1.16 & 1.205 & 1.858 & 1.09 & 1.102 & 18.7763 & 0.716 & 0.717 \\
\hline 0.1985 & 1.159 & 1.242 & 1.968 & 1.086 & 1.099 & 19.8913 & 0.697 & 0.699 \\
\hline 0.2102 & 1.156 & 1.619 & 2.0847 & 1.084 & 1.094 & 21.073 & 0.678 & 0.681 \\
\hline 0.2227 & 1.155 & 1.283 & 2.2097 & 1.082 & 1.091 & 22.3247 & 0.659 & 0.662 \\
\hline 0.2358 & 1.154 & 1.122 & 2.3412 & 1.075 & 1.088 & 23.6497 & 0.641 & 0.642 \\
\hline 0.2498 & 1.152 & 1.188 & 2.4813 & 1.073 & 1.082 & 25.0547 & 0.621 & 0.622 \\
\hline 0.2647 & 1.152 & 1.173 & 2.6297 & 1.067 & 1.078 & 26.543 & 0.601 & 0.603 \\
\hline 0.2803 & 1.151 & 1.164 & 2.7863 & 1.063 & 1.074 & 28.118 & 0.582 & 0.583 \\
\hline 0.297 & 1.149 & 1.163 & 2.953 & 1.058 & 1.069 & 29.7863 & 0.561 & 0.563 \\
\hline
\end{tabular}


TABLE A.4 (Cont.)

\begin{tabular}{|c|c|c|c|c|c|c|c|c|}
\hline \multirow{2}{*}{$\begin{array}{c}\text { Elapsed } \\
\text { Time } \\
\text { (min) }\end{array}$} & \multicolumn{2}{|c|}{$\begin{array}{c}\text { Residual } \\
\text { Drawdown (ft) }\end{array}$} & \multirow{2}{*}{$\begin{array}{c}\text { Elapsed } \\
\text { Time } \\
\text { (min) }\end{array}$} & \multicolumn{2}{|c|}{$\begin{array}{c}\text { Residual } \\
\text { Drawdown (ft) }\end{array}$} & \multirow{2}{*}{$\begin{array}{c}\text { Elapsed } \\
\text { Time } \\
\text { (min) }\end{array}$} & \multicolumn{2}{|c|}{$\begin{array}{c}\text { Residual } \\
\text { Drawdown (ft) }\end{array}$} \\
\hline & $\begin{array}{l}\text { Slug } \\
\text { In }\end{array}$ & $\begin{array}{l}\text { Slug } \\
\text { Out }\end{array}$ & & $\begin{array}{l}\text { Slug } \\
\text { In }\end{array}$ & $\begin{array}{l}\text { Slug } \\
\text { Out }\end{array}$ & & $\begin{array}{l}\text { Slug } \\
\text { In }\end{array}$ & $\begin{array}{l}\text { Slug } \\
\text { Out }\end{array}$ \\
\hline 31.5547 & 0.54 & 0.542 & 278.2747 & & 0.097 & 678.2747 & & 0.041 \\
\hline 33.428 & 0.52 & 0.52 & 288.2747 & & 0.094 & 688.2747 & & 0.041 \\
\hline 35.4112 & 0.503 & 0.5 & 298.2747 & & 0.092 & 698.2747 & & 0.04 \\
\hline 37.513 & 0.478 & 0.48 & 308.2747 & & 0.09 & 708.2747 & & 0.039 \\
\hline 39.7397 & 0.456 & 0.46 & 318.2747 & & 0.088 & 718.2747 & & 0.039 \\
\hline 42.098 & 0.437 & 0.44 & 328.2747 & & 0.086 & 728.2747 & & 0.039 \\
\hline 44.5963 & 0.416 & 0.419 & 338.2747 & & 0.084 & 738.2747 & & 0.038 \\
\hline 47.243 & 0.396 & 0.4 & 348.2747 & & 0.081 & 748.2747 & & 0.038 \\
\hline 50.0463 & 0.376 & 0.379 & 358.2747 & & 0.079 & 758.2747 & & 0.038 \\
\hline 53.0147 & 0.356 & 0.361 & 368.2747 & & 0.077 & 768.2747 & & 0.037 \\
\hline 56.1597 & 0.339 & 0.344 & 378.2747 & & 0.076 & 778.2747 & & 0.037 \\
\hline 59.4913 & 0.319 & 0.326 & 388.2747 & & 0.074 & 788.2747 & & 0.036 \\
\hline 63.0197 & 0.302 & 0.308 & 398.2747 & & 0.073 & 798.2747 & & 0.037 \\
\hline 66.758 & 0.284 & 0.292 & 408.2747 & & 0.071 & 808.2747 & & 0.036 \\
\hline 70.718 & 0.27 & 0.276 & 418.2747 & & 0.07 & 818.2747 & & 0.036 \\
\hline 74.9113 & 0.254 & 0.262 & 428.2747 & & 0.068 & 828.2747 & & 0.034 \\
\hline 79.3547 & 0.239 & 0.248 & 438.2747 & & 0.066 & 838.2747 & & 0.032 \\
\hline 84.0613 & 0.226 & 0.234 & 448.2747 & & 0.065 & & & \\
\hline 89.0463 & 0.213 & 0.223 & 458.2747 & & 0.065 & & & \\
\hline 94.3263 & 0.199 & 0.211 & 468.2747 & & 0.065 & & & \\
\hline 99.9197 & 0.187 & 0.199 & 478.2747 & & 0.063 & & & \\
\hline 105.8447 & 0.177 & 0.19 & 488.2747 & & 0.062 & & & \\
\hline 112.1197 & 0.166 & 0.18 & 498.2747 & & 0.06 & & & \\
\hline 118.768 & 0.158 & 0.172 & 508.2747 & & 0.06 & & & \\
\hline 125.8097 & 0.149 & 0.164 & 518.2747 & & 0.06 & & & \\
\hline 133.268 & 0.142 & 0.157 & 528.2747 & & 0.058 & & & \\
\hline 141.168 & 0.133 & 0.15 & 538.2747 & & 0.057 & & & \\
\hline 149.5363 & 0.128 & 0.144 & 548.2747 & & 0.056 & & & \\
\hline 158.4013 & 0.121 & 0.138 & 558.2747 & & 0.056 & & & \\
\hline 167.7913 & 0.117 & 0.132 & 568.2747 & & 0.054 & & & \\
\hline 177.738 & 0.112 & 0.127 & 578.2747 & & 0.053 & & & \\
\hline 188.2747 & 0.106 & 0.125 & 588.2747 & & 0.051 & & & \\
\hline 198.2747 & 0.104 & 0.12 & 598.2747 & & 0.05 & & & \\
\hline 208.2747 & & 0.116 & 608.2747 & & 0.049 & & & \\
\hline 218.2747 & & 0.114 & 618.2747 & & 0.048 & & & \\
\hline 228.2747 & & 0.109 & 628.2747 & & 0.045 & & & \\
\hline 238.2747 & & 0.106 & 638.2747 & & 0.044 & & & \\
\hline 248.2747 & & 0.104 & 648.2747 & & 0.043 & & & \\
\hline 258.2747 & & 0.101 & 658.2747 & & 0.043 & & & \\
\hline 268.2747 & & 0.099 & 668.2747 & & 0.043 & & & \\
\hline
\end{tabular}


TABLE A.5 Slug test data for boring MW06 (effective saturated thickness $=10 \mathrm{ft}$ : length of well $=10 \mathrm{ft}$; length of screen $=10 \mathrm{ft}$; casing radius $=0.1667 \mathrm{ft}$; borehole radius $=0.4792 \mathrm{ft} ; \mathrm{Kz} / \mathrm{Kr}=1$ ).

\begin{tabular}{|c|c|c|c|c|c|}
\hline \multirow[b]{2}{*}{$\begin{array}{l}\text { Elapsed } \\
\text { Time } \\
\text { (min) }\end{array}$} & \multicolumn{2}{|c|}{$\begin{array}{c}\text { Residual } \\
\text { Drawdown (ft) }\end{array}$} & \multirow[b]{2}{*}{$\begin{array}{c}\text { Elapsed } \\
\text { Time } \\
\text { (min) }\end{array}$} & \multicolumn{2}{|c|}{$\begin{array}{c}\text { Residual } \\
\text { Drawdown (ft) }\end{array}$} \\
\hline & $\begin{array}{l}\text { Slug } \\
\text { In }\end{array}$ & $\begin{array}{l}\text { Slug } \\
\text { Out }\end{array}$ & & $\begin{array}{l}\text { Slug } \\
\text { In }\end{array}$ & $\begin{array}{l}\text { Slug } \\
\text { Out }\end{array}$ \\
\hline 0 & & & 0.3147 & 0.861 & 1.535 \\
\hline 0.005 & 0.002 & & 0.3333 & 0.861 & 1.553 \\
\hline 0.01 & 0.004 & & 0.3532 & 0.859 & 1.558 \\
\hline 0.015 & 0.007 & & 0.3742 & 0.859 & 1.04 \\
\hline 0.02 & 0.007 & & 0.3963 & 0.857 & 1.031 \\
\hline 0.025 & 0.007 & 1.113 & 0.4198 & 0.854 & 1.026 \\
\hline 0.03 & 0.006 & 0.025 & 0.4447 & 0.854 & 1.026 \\
\hline 0.035 & 0.009 & 0.802 & 0.4697 & 0.854 & 1.026 \\
\hline 0.04 & 0.006 & 0.102 & 0.4963 & 0.852 & 1.024 \\
\hline 0.045 & 0.009 & 0.588 & 0.5247 & 0.852 & 1.022 \\
\hline 0.05 & 0.009 & 1.24 & 0.5547 & 0.85 & 1.02 \\
\hline 0.055 & 0.009 & 1.086 & 0.5863 & 0.848 & 1.02 \\
\hline 0.06 & 0.22 & 1.113 & 0.6213 & 0.848 & 1.018 \\
\hline 0.065 & 1.471 & 1.071 & 0.6578 & 0.846 & 1.015 \\
\hline 0.07 & 1.605 & 1.071 & 0.6963 & 0.843 & 1.015 \\
\hline 0.075 & 0.828 & 1.066 & 0.738 & 0.843 & 1.015 \\
\hline 0.08 & 1.154 & 1.06 & 0.7813 & 0.841 & 1.011 \\
\hline 0.0848 & 0.231 & 1.058 & 0.828 & 0.841 & 1.009 \\
\hline 0.09 & 0.817 & 1.058 & 0.8763 & 0.839 & 1.009 \\
\hline 0.095 & 0.973 & 1.056 & 0.928 & 0.837 & 1.007 \\
\hline 0.1 & 0.982 & 1.053 & 0.983 & 0.835 & 1.004 \\
\hline 0.1058 & 0.801 & 1.051 & 1.0413 & 0.832 & 1.002 \\
\hline 0.112 & 0.83 & 1.051 & 1.103 & 0.83 & 1 \\
\hline 0.1185 & 0.938 & 1.051 & 1.168 & 0.83 & 0.998 \\
\hline 0.1255 & 0.891 & 1.049 & 1.238 & 0.826 & 0.996 \\
\hline 0.1328 & 0.865 & 1.051 & 1.3113 & 0.826 & 0.995 \\
\hline 0.1407 & 0.867 & 1.051 & 1.3897 & 0.826 & 0.993 \\
\hline 0.149 & 0.872 & 1.051 & 1.473 & 0.822 & 0.991 \\
\hline 0.1578 & 0.872 & 1.049 & 1.5613 & 0.819 & 0.987 \\
\hline 0.167 & 0.87 & 1.047 & 1.6547 & 0.817 & 0.984 \\
\hline 0.177 & 0.87 & 1.051 & 1.753 & 0.815 & 0.982 \\
\hline 0.1875 & 0.867 & 1.049 & 1.858 & 0.813 & 0.98 \\
\hline 0.1985 & 0.865 & 1.055 & 1.968 & 0.811 & 0.976 \\
\hline 0.2102 & 0.867 & 1.071 & 2.0847 & 0.806 & 0.973 \\
\hline 0.2227 & 0.865 & 1.066 & 2.2097 & 0.804 & 0.971 \\
\hline 0.2358 & 0.863 & 1.084 & 2.3412 & 0.8 & 0.967 \\
\hline 0.2498 & 0.863 & 2.262 & 2.4813 & 0.8 & 0.965 \\
\hline 0.2647 & 0.863 & 1.969 & 2.6297 & 0.795 & 0.96 \\
\hline 0.2803 & 0.861 & 1.864 & 2.7863 & 0.791 & 0.958 \\
\hline 0.297 & 0.861 & 1.857 & 2.953 & 0.789 & 0.954 \\
\hline
\end{tabular}


TABLE A.5 (Cont.)

\begin{tabular}{|c|c|c|c|c|c|}
\hline \multirow{2}{*}{$\begin{array}{c}\text { Elapsed } \\
\text { Time } \\
\text { (min) }\end{array}$} & \multicolumn{2}{|c|}{$\begin{array}{c}\text { Residual } \\
\text { Drawdown (ft) }\end{array}$} & \multirow{2}{*}{$\begin{array}{c}\text { Elapsed } \\
\text { Time } \\
\text { (min) }\end{array}$} & \multicolumn{2}{|c|}{$\begin{array}{c}\text { Residual } \\
\text { Drawdown (ft) }\end{array}$} \\
\hline & $\begin{array}{l}\text { Slug } \\
\text { In }\end{array}$ & $\begin{array}{l}\text { Slug } \\
\text { Out }\end{array}$ & & $\begin{array}{l}\text { Slug } \\
\text { In }\end{array}$ & $\begin{array}{l}\text { Slug } \\
\text { Out }\end{array}$ \\
\hline 3.1297 & 0.784 & 0.949 & 33.428 & 0.491 & 0.663 \\
\hline 3.3163 & 0.78 & 0.947 & 35.4112 & 0.482 & 0.656 \\
\hline 3.5147 & 0.778 & 0.94 & 37.513 & 0.473 & 0.647 \\
\hline 3.7247 & 0.771 & 0.936 & 39.7397 & 0.462 & 0.639 \\
\hline 3.9463 & 0.769 & 0.934 & 42.098 & 0.453 & 0.632 \\
\hline 4.1813 & 0.762 & 0.927 & 44.5963 & 0.444 & 0.623 \\
\hline 4.4295 & 0.76 & 0.923 & 47.243 & 0.433 & 0.614 \\
\hline 4.693 & 0.754 & 0.918 & 50.0463 & 0.424 & 0.606 \\
\hline 4.973 & 0.749 & 0.914 & 53.0147 & 0.413 & 0.597 \\
\hline 5.2697 & 0.743 & 0.907 & 56.1597 & 0.405 & 0.588 \\
\hline 5.583 & 0.738 & 0.903 & 59.4913 & 0.394 & 0.581 \\
\hline 5.9147 & 0.732 & 0.898 & 63.0197 & 0.383 & 0.573 \\
\hline 6.2663 & 0.725 & 0.892 & 66.758 & 0.374 & 0.566 \\
\hline 6.6397 & 0.721 & 0.887 & 70.718 & 0.365 & 0.557 \\
\hline 7.0347 & 0.714 & 0.881 & 74.9113 & 0.354 & 0.551 \\
\hline 7.453 & 0.707 & 0.874 & 79.3547 & 0.345 & 0.542 \\
\hline 7.8963 & 0.703 & 0.868 & 84.0613 & 0.334 & 0.533 \\
\hline 8.3663 & 0.696 & 0.859 & 89.0463 & 0.325 & 0.524 \\
\hline 8.8647 & 0.69 & 0.852 & 94.3263 & 0.316 & 0.518 \\
\hline 9.3913 & 0.683 & 0.848 & 99.9197 & 0.307 & 0.511 \\
\hline 9.9497 & 0.674 & 0.839 & 105.8447 & 0.296 & 0.504 \\
\hline 10.5413 & 0.666 & 0.834 & 112.1197 & 0.288 & 0.498 \\
\hline 11.168 & 0.659 & 0.826 & 118.768 & 0.279 & 0.489 \\
\hline 11.8313 & 0.652 & 0.819 & 125.8097 & 0.27 & 0.482 \\
\hline 12.5347 & 0.643 & 0.81 & 133.268 & 0.259 & 0.473 \\
\hline 13.2797 & 0.635 & 0.804 & 141.168 & 0.25 & 0.467 \\
\hline 14.0697 & 0.628 & 0.795 & 149.5363 & 0.241 & 0.46 \\
\hline 14.9063 & 0.619 & 0.786 & 158.4013 & 0.23 & 0.454 \\
\hline 15.7913 & 0.611 & 0.777 & 167.7913 & 0.221 & 0.447 \\
\hline 16.7297 & 0.602 & 0.768 & 177.738 & 0.215 & 0.441 \\
\hline 17.723 & 0.593 & 0.762 & 188.2747 & 0.203 & 0.434 \\
\hline 18.7763 & 0.584 & 0.751 & 198.2747 & 0.195 & 0.429 \\
\hline 19.8913 & 0.574 & 0.744 & 208.2747 & 0.188 & 0.423 \\
\hline 21.073 & 0.567 & 0.733 & 218.2747 & 0.177 & \\
\hline 22.3247 & 0.558 & 0.724 & 228.2747 & 0.17 & \\
\hline 23.6497 & 0.547 & 0.716 & 238.2747 & 0.162 & \\
\hline 25.0547 & 0.538 & 0.709 & & & \\
\hline 26.543 & 0.53 & 0.698 & & & \\
\hline 28.118 & 0.519 & 0.692 & & & \\
\hline 29.7863 & 0.51 & 0.683 & & & \\
\hline 31.5547 & 0.5 & 0.674 & & & \\
\hline
\end{tabular}


TABLE A.6 Slug test data for boring MW07 (effective saturated thickness $=10 \mathrm{ft}$ : length of well $=10 \mathrm{ft}$; length of screen $=10 \mathrm{ft}$; casing radius $=0.08333 \mathrm{ft}$; borehole radius $=0.3438 \mathrm{ft} ; \mathrm{Kz} / \mathrm{Kr}=1$ ).

\begin{tabular}{|c|c|c|c|c|c|c|c|c|}
\hline \multirow{2}{*}{$\begin{array}{c}\text { Elapsed } \\
\text { Time } \\
\text { (min) }\end{array}$} & \multicolumn{2}{|c|}{$\begin{array}{c}\text { Residual } \\
\text { Drawdown (ft) }\end{array}$} & \multirow{2}{*}{$\begin{array}{c}\text { Elapsed } \\
\text { Time } \\
\text { (min) }\end{array}$} & \multicolumn{2}{|c|}{$\begin{array}{c}\text { Residual } \\
\text { Drawdown (ft) }\end{array}$} & \multirow{2}{*}{$\begin{array}{c}\text { Elapsed } \\
\text { Time } \\
\text { (min) }\end{array}$} & \multicolumn{2}{|c|}{$\begin{array}{c}\text { Residual } \\
\text { Drawdown (ft) }\end{array}$} \\
\hline & $\underset{\text { Slug }}{\text { Slug }}$ & $\begin{array}{l}\text { Slug } \\
\text { Out }\end{array}$ & & $\underset{\ln }{\text { Slug }}$ & $\begin{array}{l}\text { Slug } \\
\text { Out }\end{array}$ & & $\underset{\text { Slug }}{\text { Slug }}$ & $\begin{array}{l}\text { Slug } \\
\text { Out }\end{array}$ \\
\hline 0 & & & 0.5863 & 0.584 & 0.647 & 11.168 & 0.223 & 0.385 \\
\hline 0.005 & 0.198 & 0.641 & 0.6213 & 0.582 & 0.646 & 11.8313 & 0.211 & 0.374 \\
\hline 0.01 & 1.151 & 0.538 & 0.6578 & 0.578 & 0.644 & 12.5347 & 0.197 & 0.363 \\
\hline 0.015 & 1.364 & 0.399 & 0.6963 & 0.575 & 0.641 & 13.2797 & 0.185 & 0.353 \\
\hline 0.02 & 0.569 & 0.776 & 0.738 & 0.572 & 0.64 & 14.0697 & 0.171 & 0.341 \\
\hline 0.025 & 0.166 & 1.11 & 0.7813 & 0.57 & 0.638 & 14.9063 & 0.159 & 0.33 \\
\hline 0.03 & 0.559 & 0.917 & 0.828 & 0.567 & 0.635 & 15.7913 & 0.146 & 0.318 \\
\hline 0.035 & 0.925 & 0.58 & 0.8763 & 0.563 & 0.633 & 16.7297 & 0.133 & 0.306 \\
\hline 0.04 & 0.873 & 0.594 & 0.928 & 0.56 & 0.629 & 17.723 & 0.122 & 0.294 \\
\hline 0.045 & 0.595 & 0.808 & 0.983 & 0.554 & 0.627 & 18.7763 & 0.107 & 0.282 \\
\hline 0.05 & 0.513 & 0.859 & 1.0413 & 0.552 & 0.625 & 19.8913 & 0.095 & 0.269 \\
\hline 0.055 & 0.655 & 0.716 & 1.103 & 0.548 & 0.622 & 21.073 & 0.083 & 0.257 \\
\hline 0.06 & 0.762 & 0.618 & 1.168 & 0.543 & 0.619 & 22.3247 & 0.07 & 0.245 \\
\hline 0.065 & 0.712 & 0.673 & 1.238 & 0.539 & 0.616 & 23.6497 & 0.058 & 0.233 \\
\hline 0.07 & 0.613 & 0.761 & 1.3113 & 0.535 & 0.614 & 25.0547 & 0.047 & 0.221 \\
\hline 0.075 & 0.596 & 0.74 & 1.3897 & 0.53 & 0.61 & 26.543 & 0.036 & 0.208 \\
\hline 0.08 & 0.65 & 0.672 & 1.473 & 0.525 & 0.606 & 28.118 & 0.025 & 0.197 \\
\hline 0.0848 & 0.687 & 0.654 & 1.5613 & 0.52 & 0.604 & 29.7863 & 0.014 & 0.185 \\
\hline 0.09 & 0.662 & 0.695 & 1.6547 & 0.515 & 0.599 & 31.5547 & 0.003 & 0.174 \\
\hline 0.095 & 0.625 & 0.717 & 1.753 & 0.511 & 0.597 & 33.428 & & 0.162 \\
\hline 0.1 & 0.622 & 0.693 & 1.858 & 0.501 & 0.593 & 35.4112 & & 0.151 \\
\hline 0.1058 & 0.647 & 0.665 & 1.968 & 0.495 & 0.589 & 37.513 & & 0.14 \\
\hline 0.112 & 0.651 & 0.678 & 2.0847 & 0.49 & 0.585 & 39.7397 & & 0.13 \\
\hline 0.1185 & 0.633 & 0.692 & 2.2097 & 0.484 & 0.587 & 42.098 & & 0.12 \\
\hline 0.1255 & 0.628 & 0.674 & 2.3412 & 0.476 & 0.582 & 44.5963 & & 0.109 \\
\hline 0.1328 & 0.639 & 0.672 & 2.4813 & 0.471 & 0.578 & 47.243 & & 0.099 \\
\hline 0.1407 & 0.634 & 0.68 & 2.6297 & 0.463 & 0.575 & 50.0463 & & 0.09 \\
\hline 0.149 & 0.627 & 0.671 & 2.7863 & 0.457 & 0.566 & 53.0147 & & 0.083 \\
\hline 0.1578 & 0.631 & 0.67 & 2.953 & 0.45 & 0.561 & 56.1597 & & 0.074 \\
\hline 0.167 & 0.624 & 0.674 & 3.1297 & 0.442 & 0.555 & 59.4913 & & 0.066 \\
\hline 0.177 & 0.621 & 0.671 & 3.3163 & 0.435 & 0.55 & 63.0197 & & 0.058 \\
\hline 0.1875 & 0.621 & 0.672 & 3.5147 & 0.427 & 0.544 & 66.758 & & 0.052 \\
\hline 0.1985 & 0.619 & 0.67 & 3.7247 & 0.42 & 0.54 & 70.718 & & 0.045 \\
\hline 0.2102 & 0.618 & 0.67 & 3.9463 & 0.412 & 0.533 & 74.9113 & & 0.039 \\
\hline 0.2227 & 0.616 & 0.669 & 4.1813 & 0.403 & 0.527 & 79.3547 & & 0.033 \\
\hline 0.2358 & 0.615 & 0.669 & 4.4295 & 0.394 & 0.52 & 84.0613 & & 0.028 \\
\hline 0.2498 & 0.611 & 0.668 & 4.693 & 0.405 & 0.513 & 89.0463 & & 0.023 \\
\hline 0.2647 & 0.61 & 0.666 & 4.973 & 0.373 & 0.507 & 94.3263 & & 0.019 \\
\hline 0.2803 & 0.609 & 0.666 & 5.2697 & 0.365 & 0.5 & 99.9197 & & 0.015 \\
\hline 0.297 & 0.607 & 0.664 & 5.583 & 0.356 & 0.492 & 105.8447 & & 0.011 \\
\hline 0.3147 & 0.606 & 0.663 & 5.9147 & 0.347 & 0.485 & 112.1197 & & 0.008 \\
\hline 0.3333 & 0.604 & 0.663 & 6.2663 & 0.338 & 0.477 & 118.768 & & 0.005 \\
\hline 0.3532 & 0.604 & 0.661 & 6.6397 & 0.327 & 0.468 & 125.8097 & & 0.002 \\
\hline 0.3742 & 0.6 & 0.659 & 7.0347 & 0.317 & 0.461 & & & \\
\hline 0.3963 & 0.599 & 0.658 & 7.453 & 0.306 & 0.453 & & & \\
\hline 0.4198 & 0.596 & 0.657 & 7.8963 & 0.294 & 0.443 & & & \\
\hline 0.4447 & 0.595 & 0.656 & 8.3663 & 0.283 & 0.434 & & & \\
\hline 0.4697 & 0.593 & 0.653 & 8.8647 & 0.271 & 0.425 & & & \\
\hline 0.4963 & 0.59 & 0.652 & 9.3913 & 0.26 & 0.416 & & & \\
\hline 0.5247 & 0.588 & 0.65 & 9.9497 & 0.247 & 0.405 & & & \\
\hline 0.5547 & 0.586 & 0.648 & 10.5413 & 0.235 & 0.396 & & & \\
\hline
\end{tabular}


TABLE A.7 Slug test data for boring MW08 (effective saturated thickness = $15 \mathrm{ft}$ : length of well $=15 \mathrm{ft}$; length of screen $=15 \mathrm{ft}$; casing radius $=0.08333 \mathrm{ft}$; borehole radius $=0.3438 \mathrm{ft} ; \mathrm{Kz} / \mathrm{Kr}=1$ ).

\begin{tabular}{|c|c|c|c|c|c|c|c|}
\hline \multirow[b]{2}{*}{$\begin{array}{c}\text { Elapsed } \\
\text { Time } \\
\text { (min) }\end{array}$} & \multicolumn{3}{|c|}{ Residual Drawdown (ft) } & \multirow[b]{2}{*}{$\begin{array}{c}\text { Elapsed } \\
\text { Time } \\
\text { (min) }\end{array}$} & \multicolumn{3}{|c|}{ Residual Drawdown (ft) } \\
\hline & $\begin{array}{l}\text { Test } 6 \\
\text { Step } 0\end{array}$ & $\begin{array}{l}\text { Test } 7 \\
\text { Step } 0\end{array}$ & $\begin{array}{l}\text { Test } 7 \\
\text { Step } 1\end{array}$ & & $\begin{array}{l}\text { Test } 6 \\
\text { Step } 0\end{array}$ & $\begin{array}{l}\text { Test } 7 \\
\text { Step } 0\end{array}$ & $\begin{array}{l}\text { Test } 7 \\
\text { Step } 1\end{array}$ \\
\hline 0 & 6.248 & 4.901 & 6.75 & 0.1333 & 3.543 & 2.799 & 3.793 \\
\hline 0.0033 & 5.367 & 4.259 & 5.234 & 0.1366 & 3.53 & 2.793 & 3.781 \\
\hline 0.0066 & 3.429 & 2.774 & 3.523 & 0.14 & 3.517 & 2.78 & 3.768 \\
\hline 0.01 & 3.832 & 2.957 & 4.309 & 0.1433 & 3.505 & 2.768 & 3.762 \\
\hline 0.0133 & 4.656 & 3.636 & 5.026 & 0.1466 & 3.492 & 2.762 & 3.749 \\
\hline 0.0166 & 4.373 & 3.548 & 4.573 & 0.15 & 3.48 & 2.749 & 3.737 \\
\hline 0.02 & 3.889 & 3.158 & 4.139 & 0.1533 & 3.473 & 2.743 & 3.724 \\
\hline 0.0233 & 3.958 & 3.12 & 4.271 & 0.1566 & 3.461 & 2.736 & 3.712 \\
\hline 0.0266 & 4.134 & 3.259 & 4.416 & 0.16 & 3.448 & 2.724 & 3.699 \\
\hline 0.03 & 4.065 & 3.246 & 4.309 & 0.1633 & 3.436 & 2.711 & 3.686 \\
\hline 0.0333 & 3.939 & 3.145 & 4.209 & 0.1666 & 3.423 & 2.705 & 3.68 \\
\hline 0.0366 & 3.933 & 3.114 & 4.215 & 0.17 & 3.41 & 2.699 & 3.668 \\
\hline 0.04 & 3.958 & 3.133 & 4.227 & 0.1733 & 3.398 & 2.686 & 3.655 \\
\hline 0.0433 & 3.926 & 3.126 & 4.19 & 0.1766 & 3.385 & 2.68 & 3.642 \\
\hline 0.0466 & 3.889 & 3.095 & 4.158 & 0.18 & 3.373 & 2.667 & 3.63 \\
\hline 0.05 & 3.876 & 3.076 & 4.146 & 0.1833 & 3.36 & 2.661 & 3.623 \\
\hline 0.0533 & 3.87 & 3.07 & 4.133 & 0.1866 & 3.354 & 2.648 & 3.611 \\
\hline 0.0566 & 3.851 & 3.057 & 4.114 & 0.19 & 3.341 & 2.642 & 3.598 \\
\hline 0.06 & 3.826 & 3.038 & 4.095 & 0.1933 & 3.329 & 2.636 & 3.586 \\
\hline 0.0633 & 3.813 & 3.026 & 4.083 & 0.1966 & 3.322 & 2.623 & 3.579 \\
\hline 0.0666 & 3.801 & 3.013 & 4.064 & 0.2 & 3.31 & 2.617 & 3.567 \\
\hline 0.07 & 3.788 & 3.001 & 4.051 & 0.2033 & 3.297 & 2.604 & 3.554 \\
\hline 0.0733 & 3.769 & 2.988 & 4.039 & 0.2066 & 3.291 & 2.598 & 3.548 \\
\hline 0.0766 & 3.756 & 2.975 & 4.02 & 0.21 & 3.278 & 2.592 & 3.535 \\
\hline 0.08 & 3.744 & 2.969 & 4.007 & 0.2133 & 3.266 & 2.579 & 3.523 \\
\hline 0.0833 & 3.731 & 2.957 & 3.995 & 0.2166 & 3.253 & 2.573 & 3.51 \\
\hline 0.0866 & 3.712 & 2.944 & 3.976 & 0.22 & 3.247 & 2.56 & 3.504 \\
\hline 0.09 & 3.706 & 2.931 & 3.963 & 0.2233 & 3.234 & 2.554 & 3.491 \\
\hline 0.0933 & 3.694 & 2.925 & 3.951 & 0.2266 & 3.222 & 2.548 & 3.479 \\
\hline 0.0966 & 3.675 & 2.913 & 3.938 & 0.23 & 3.209 & 2.535 & 3.472 \\
\hline 0.1 & 3.662 & 2.9 & 3.925 & 0.2333 & 3.203 & 2.529 & 3.46 \\
\hline 0.1033 & 3.65 & 2.887 & 3.913 & 0.2366 & 3.19 & 2.523 & 3.447 \\
\hline 0.1066 & 3.637 & 2.881 & 3.894 & 0.24 & 3.184 & 2.51 & 3.441 \\
\hline 0.11 & 3.624 & 2.869 & 3.888 & 0.2433 & 3.171 & 2.504 & 3.428 \\
\hline 0.1133 & 3.612 & 2.862 & 3.869 & 0.2466 & 3.159 & 2.497 & 3.416 \\
\hline 0.1166 & 3.599 & 2.85 & 3.856 & 0.25 & 3.146 & 2.491 & 3.41 \\
\hline 0.12 & 3.587 & 2.837 & 3.844 & 0.2533 & 3.14 & 2.478 & 3.397 \\
\hline 0.1233 & 3.574 & 2.831 & 3.831 & 0.2566 & 3.127 & 2.472 & 3.391 \\
\hline 0.1266 & 3.561 & 2.818 & 3.819 & 0.26 & 3.121 & 2.466 & 3.378 \\
\hline 0.13 & 3.549 & 2.812 & 3.806 & 0.2633 & 3.109 & 2.453 & 3.366 \\
\hline
\end{tabular}


TABLE A.7 (Cont.)

\begin{tabular}{|c|c|c|c|c|c|c|c|}
\hline \multirow{2}{*}{$\begin{array}{c}\text { Elapsed } \\
\text { Time } \\
\text { (min) }\end{array}$} & \multicolumn{3}{|c|}{ Residual Drawdown (ft) } & \multirow{2}{*}{$\begin{array}{c}\text { Elapsed } \\
\text { Time } \\
\text { (min) }\end{array}$} & \multicolumn{3}{|c|}{ Residual Drawdown (ft) } \\
\hline & $\begin{array}{l}\text { Test } 6 \\
\text { Step } 0\end{array}$ & $\begin{array}{l}\text { Test } 7 \\
\text { Step } 0\end{array}$ & $\begin{array}{l}\text { Test } 7 \\
\text { Step } 1\end{array}$ & & $\begin{array}{l}\text { Test } 6 \\
\text { Step } 0\end{array}$ & $\begin{array}{l}\text { Test } 7 \\
\text { Step } 0\end{array}$ & $\begin{array}{l}\text { Test } 7 \\
\text { Step } 1\end{array}$ \\
\hline 0.2666 & 3.102 & 2.447 & 3.359 & 0.7 & 2.077 & 1.629 & 2.327 \\
\hline 0.27 & 3.096 & 2.441 & 3.347 & 0.7166 & 2.045 & 1.604 & 2.296 \\
\hline 0.2733 & 3.077 & 2.434 & 3.34 & 0.7333 & 2.014 & 1.579 & 2.265 \\
\hline 0.2766 & 3.071 & 2.422 & 3.328 & 0.75 & 1.989 & 1.554 & 2.233 \\
\hline 0.28 & 3.058 & 2.416 & 3.322 & 0.7666 & 1.951 & 1.528 & 2.202 \\
\hline 0.2833 & 3.052 & 2.409 & 3.309 & 0.7833 & 1.926 & 1.51 & 2.17 \\
\hline 0.2866 & 3.039 & 2.403 & 3.303 & 0.8 & 1.894 & 1.484 & 2.139 \\
\hline 0.29 & 3.027 & 2.39 & 3.29 & 0.8166 & 1.869 & 1.459 & 2.107 \\
\hline 0.2933 & 3.02 & 2.384 & 3.277 & 0.8333 & 1.844 & 1.44 & 2.082 \\
\hline 0.2966 & 3.014 & 2.378 & 3.271 & 0.85 & 1.812 & 1.415 & 2.051 \\
\hline 0.3 & 3.002 & 2.372 & 3.259 & 0.8666 & 1.787 & 1.396 & 2.026 \\
\hline 0.3033 & 2.995 & 2.359 & 3.252 & 0.8833 & 1.756 & 1.371 & 1.994 \\
\hline 0.3066 & 2.983 & 2.353 & 3.24 & 0.9 & 1.731 & 1.352 & 1.969 \\
\hline 0.31 & 2.976 & 2.346 & 3.233 & 0.9166 & 1.705 & 1.333 & 1.937 \\
\hline 0.3133 & 2.964 & 2.34 & 3.227 & 0.9333 & 1.68 & 1.308 & 1.912 \\
\hline 0.3166 & 2.958 & 2.334 & 3.215 & 0.95 & 1.655 & 1.289 & 1.887 \\
\hline 0.32 & 2.945 & 2.321 & 3.202 & 0.9666 & 1.63 & 1.27 & 1.862 \\
\hline 0.3233 & 2.932 & 2.315 & 3.196 & 0.9833 & 1.605 & 1.252 & 1.837 \\
\hline 0.3266 & 2.926 & 2.309 & 3.183 & 1 & 1.58 & 1.233 & 1.812 \\
\hline 0.33 & 2.92 & 2.302 & 3.177 & 1.2 & 1.341 & 1.031 & 1.547 \\
\hline 0.3333 & 2.907 & 2.296 & 3.164 & 1.4 & 1.114 & 0.862 & 1.308 \\
\hline 0.35 & 2.863 & 2.258 & 3.12 & 1.6 & 0.925 & 0.717 & 1.107 \\
\hline 0.3666 & 2.819 & 2.22 & 3.076 & 1.8 & 0.774 & 0.591 & 0.937 \\
\hline 0.3833 & 2.775 & 2.189 & 3.038 & 2 & 0.642 & 0.497 & 0.792 \\
\hline 0.4 & 2.737 & 2.151 & 2.994 & 2.2 & 0.542 & 0.415 & 0.673 \\
\hline 0.4166 & 2.693 & 2.12 & 2.95 & 2.4 & 0.453 & 0.346 & 0.572 \\
\hline 0.4333 & 2.649 & 2.088 & 2.913 & 2.6 & 0.378 & 0.289 & 0.484 \\
\hline 0.45 & 2.611 & 2.057 & 2.869 & 2.8 & 0.315 & 0.245 & 0.415 \\
\hline 0.4666 & 2.574 & 2.026 & 2.831 & 3 & 0.265 & 0.201 & 0.352 \\
\hline 0.4833 & 2.53 & 1.988 & 2.787 & 3.2 & 0.221 & 0.163 & 0.295 \\
\hline 0.5 & 2.492 & 1.963 & 2.749 & 3.4 & 0.183 & 0.138 & 0.251 \\
\hline 0.5166 & 2.454 & 1.931 & 2.711 & 3.6 & 0.158 & 0.119 & 0.213 \\
\hline 0.5333 & 2.416 & 1.9 & 2.673 & 3.8 & 0.133 & 0.1 & 0.182 \\
\hline 0.55 & 2.379 & 1.868 & 2.636 & 4 & 0.107 & 0.081 & 0.157 \\
\hline 0.5666 & 2.347 & 1.843 & 2.598 & 4.2 & 0.095 & 0.069 & 0.132 \\
\hline 0.5833 & 2.31 & 1.812 & 2.567 & 4.4 & 0.082 & 0.056 & 0.113 \\
\hline 0.6 & 2.272 & 1.786 & 2.529 & 4.6 & 0.07 & 0.05 & 0.094 \\
\hline 0.6166 & 2.24 & 1.755 & 2.491 & 4.8 & 0.057 & 0.044 & 0.081 \\
\hline 0.6333 & 2.209 & 1.73 & 2.46 & 5 & 0.044 & 0.037 & 0.069 \\
\hline 0.65 & 2.171 & 1.705 & 2.428 & 5.2 & 0.044 & 0.031 & 0.062 \\
\hline 0.6666 & 2.14 & 1.679 & 2.39 & 5.4 & 0.038 & 0.025 & 0.05 \\
\hline 0.6833 & 2.108 & 1.654 & 2.359 & 5.6 & 0.032 & 0.018 & 0.044 \\
\hline
\end{tabular}


TABLE A.7 (Cont.)

\begin{tabular}{|c|c|c|c|c|c|c|c|}
\hline \multirow[b]{2}{*}{$\begin{array}{c}\text { Elapsed } \\
\text { Time } \\
\text { (min) }\end{array}$} & \multicolumn{3}{|c|}{ Residual Drawdown (ft) } & \multirow[b]{2}{*}{$\begin{array}{c}\text { Elapsed } \\
\text { Time } \\
\text { (min) }\end{array}$} & \multicolumn{3}{|c|}{ Residual Drawdown (ft) } \\
\hline & $\begin{array}{l}\text { Test } 6 \\
\text { Step } 0\end{array}$ & $\begin{array}{l}\text { Test } 7 \\
\text { Step } 0\end{array}$ & $\begin{array}{l}\text { Test } 7 \\
\text { Step } 1\end{array}$ & & $\begin{array}{l}\text { Test } 6 \\
\text { Step } 0\end{array}$ & $\begin{array}{l}\text { Test } 7 \\
\text { Step } 0\end{array}$ & $\begin{array}{l}\text { Test } 7 \\
\text { Step } 1\end{array}$ \\
\hline 5.8 & 0.026 & 0.018 & 0.037 & 7.2 & 0.007 & 0.006 & 0.012 \\
\hline 6 & 0.019 & 0.012 & 0.031 & 7.4 & 0.007 & 0.006 & 0.012 \\
\hline 6.2 & 0.019 & 0.012 & 0.031 & 7.6 & 0.007 & 0.006 & 0.012 \\
\hline 6.4 & 0.013 & 0.012 & 0.025 & 7.8 & 0.007 & 0.006 & 0.012 \\
\hline 6.6 & 0.013 & 0.006 & 0.018 & 8 & 0.007 & 0.006 & 0.006 \\
\hline 6.8 & 0.013 & 0.006 & 0.018 & 8.2 & 0.007 & 0.006 & 0.006 \\
\hline 7 & 0.013 & 0.006 & 0.018 & & & & \\
\hline
\end{tabular}


TABLE A. 8 Slug test data for boring MW10 (effective saturated thickness $=15 \mathrm{ft}$ : length of well $=10 \mathrm{ft}$; length of screen $=10 \mathrm{ft}$; casing radius $=0.08333 \mathrm{ft}$; borehole radius $=0.3438 \mathrm{ft} ; \mathrm{Kz} / \mathrm{Kr}=1$ ).

\begin{tabular}{|c|c|c|c|c|c|c|c|}
\hline \multirow{2}{*}{$\begin{array}{c}\text { Elapsed } \\
\text { Time } \\
\text { (min) }\end{array}$} & \multicolumn{3}{|c|}{ Residual Drawdown (ft) } & \multirow{2}{*}{$\begin{array}{c}\text { Elapsed } \\
\text { Time } \\
\text { (min) }\end{array}$} & \multicolumn{3}{|c|}{ Residual Drawdown (ft) } \\
\hline & $\begin{array}{l}\text { Test } 0 \\
\text { Step } 0\end{array}$ & $\begin{array}{l}\text { Test } 0 \\
\text { Step } 1\end{array}$ & $\begin{array}{l}\text { Test } 0 \\
\text { Step } 2\end{array}$ & & $\begin{array}{l}\text { Test } 0 \\
\text { Step } 0\end{array}$ & $\begin{array}{l}\text { Test } 0 \\
\text { Step } 1\end{array}$ & $\begin{array}{l}\text { Test } 0 \\
\text { Step } 2\end{array}$ \\
\hline 0 & 4.824 & 4.616 & 3.195 & 0.1333 & 3.654 & 3.107 & 2.157 \\
\hline 0.0033 & 5.113 & 4.107 & 3.572 & 0.1366 & 3.629 & 3.138 & 2.157 \\
\hline 0.0066 & 2.302 & 1.597 & 1.622 & 0.14 & 3.622 & 3.138 & 2.107 \\
\hline 0.01 & 2.427 & 1.987 & 0.968 & 0.1433 & 3.641 & 3.107 & 2.1 \\
\hline 0.0133 & 4.622 & 4.025 & 2.27 & 0.1466 & 3.647 & 3.113 & 2.132 \\
\hline 0.0166 & 4.396 & 3.874 & 3.069 & 0.15 & 3.629 & 3.132 & 2.151 \\
\hline 0.02 & 2.748 & 2.289 & 2.377 & 0.1533 & 3.629 & 3.132 & 2.125 \\
\hline 0.0233 & 3.019 & 2.239 & 1.396 & 0.1566 & 3.641 & 3.119 & 2.1 \\
\hline 0.0266 & 4.283 & 3.534 & 1.78 & 0.16 & 3.641 & 3.113 & 2.113 \\
\hline 0.03 & 4.044 & 3.685 & 2.641 & 0.1633 & 3.629 & 3.125 & 2.138 \\
\hline 0.0333 & 3.056 & 2.692 & 2.591 & 0.1666 & 3.629 & 3.132 & 2.125 \\
\hline 0.0366 & 3.32 & 2.465 & 1.855 & 0.17 & 3.635 & 3.119 & 2.107 \\
\hline 0.04 & 4.075 & 3.295 & 1.685 & 0.1733 & 3.635 & 3.119 & 2.107 \\
\hline 0.0433 & 3.842 & 3.534 & 2.264 & 0.1766 & 3.629 & 3.125 & 2.119 \\
\hline 0.0466 & 3.251 & 2.924 & 2.553 & 0.18 & 3.629 & 3.125 & 2.125 \\
\hline 0.05 & 3.484 & 2.679 & 2.17 & 0.1833 & 3.635 & 3.119 & 2.113 \\
\hline 0.0533 & 3.93 & 3.176 & 1.805 & 0.1866 & 3.635 & 3.119 & 2.1 \\
\hline 0.0566 & 3.729 & 3.408 & 2.037 & 0.19 & 3.629 & 3.119 & 2.107 \\
\hline 0.06 & 3.39 & 3.044 & 2.396 & 0.1933 & 3.629 & 3.119 & 2.119 \\
\hline 0.0633 & 3.578 & 2.83 & 2.308 & 0.1966 & 3.629 & 3.119 & 2.113 \\
\hline 0.0666 & 3.83 & 3.119 & 1.975 & 0.2 & 3.629 & 3.113 & 2.1 \\
\hline 0.07 & 3.673 & 3.314 & 1.962 & 0.2033 & 3.622 & 3.119 & 2.1 \\
\hline 0.0733 & 3.478 & 3.1 & 2.232 & 0.2066 & 3.629 & 3.119 & 2.107 \\
\hline 0.0766 & 3.622 & 2.937 & 2.32 & 0.21 & 3.629 & 3.119 & 2.107 \\
\hline 0.08 & 3.761 & 3.1 & 2.113 & 0.2133 & 3.622 & 3.113 & 2.1 \\
\hline 0.0833 & 3.641 & 3.245 & 1.987 & 0.2166 & 3.622 & 3.119 & 2.094 \\
\hline 0.0866 & 3.541 & 3.125 & 2.119 & 0.22 & 3.622 & 3.119 & 2.1 \\
\hline 0.09 & 3.641 & 3.006 & 2.264 & 0.2233 & 3.622 & 3.119 & 2.1 \\
\hline 0.0933 & 3.717 & 3.094 & 2.188 & 0.2266 & 3.622 & 3.113 & 2.1 \\
\hline 0.0966 & 3.635 & 3.201 & 2.05 & 0.23 & 3.622 & 3.113 & 2.094 \\
\hline 0.1 & 3.578 & 3.138 & 2.069 & 0.2333 & 3.622 & 3.113 & 2.094 \\
\hline 0.1033 & 3.647 & 3.05 & 2.195 & 0.2366 & 3.622 & 3.113 & 2.094 \\
\hline 0.1066 & 3.685 & 3.094 & 2.207 & 0.24 & 3.622 & 3.113 & 2.094 \\
\hline 0.11 & 3.629 & 3.17 & 2.107 & 0.2433 & 3.616 & 3.113 & 2.088 \\
\hline 0.1133 & 3.603 & 3.138 & 2.069 & 0.2466 & 3.622 & 3.113 & 2.088 \\
\hline 0.1166 & 3.647 & 3.081 & 2.138 & 0.25 & 3.616 & 3.113 & 2.094 \\
\hline 0.12 & 3.666 & 3.1 & 2.188 & 0.2533 & 3.616 & 3.113 & 2.088 \\
\hline 0.1233 & 3.629 & 3.151 & 2.144 & 0.2566 & 3.616 & 3.113 & 2.088 \\
\hline 0.1266 & 3.616 & 3.138 & 2.088 & 0.26 & 3.616 & 3.113 & 2.088 \\
\hline 0.13 & 3.647 & 3.1 & 2.107 & 0.2633 & 3.616 & 3.113 & 2.088 \\
\hline
\end{tabular}


TABLE A.8 (Cont.)

\begin{tabular}{|c|c|c|c|c|c|c|c|}
\hline \multirow[b]{2}{*}{$\begin{array}{c}\text { Elapsed } \\
\text { Time } \\
\text { (min) }\end{array}$} & \multicolumn{3}{|c|}{ Residual Drawdown (ft) } & \multirow[b]{2}{*}{$\begin{array}{c}\text { Elapsed } \\
\text { Time } \\
\text { (min) }\end{array}$} & \multicolumn{3}{|c|}{ Residual Drawdown (ft) } \\
\hline & $\begin{array}{l}\text { Test } 0 \\
\text { Step } 0\end{array}$ & $\begin{array}{l}\text { Test } 0 \\
\text { Step } 1\end{array}$ & $\begin{array}{l}\text { Test } 0 \\
\text { Step } 2\end{array}$ & & $\begin{array}{l}\text { Test } 0 \\
\text { Step } 0\end{array}$ & $\begin{array}{l}\text { Test } 0 \\
\text { Step } 1\end{array}$ & $\begin{array}{l}\text { Test } 0 \\
\text { Step } 2\end{array}$ \\
\hline 0.2666 & 3.616 & 3.113 & 2.088 & 0.7 & 3.528 & 3.031 & 1.949 \\
\hline 0.27 & 3.616 & 3.107 & 2.081 & 0.7166 & 3.528 & 3.031 & 1.949 \\
\hline 0.2733 & 3.616 & 3.107 & 2.081 & 0.7333 & 3.522 & 3.025 & 1.943 \\
\hline 0.2766 & 3.61 & 3.107 & 2.081 & 0.75 & 3.515 & 3.019 & 1.937 \\
\hline 0.28 & 3.61 & 3.107 & 2.081 & 0.7666 & 3.515 & 3.019 & 1.93 \\
\hline 0.2833 & 3.61 & 3.107 & 2.081 & 0.7833 & 3.509 & 3.012 & 1.924 \\
\hline 0.2866 & 3.61 & 3.107 & 2.075 & 0.8 & 3.509 & 3.012 & 1.924 \\
\hline 0.29 & 3.61 & 3.107 & 2.075 & 0.8166 & 3.503 & 3.006 & 1.918 \\
\hline 0.2933 & 3.61 & 3.107 & 2.075 & 0.8333 & 3.503 & 3.006 & 1.912 \\
\hline 0.2966 & 3.61 & 3.107 & 2.075 & 0.85 & 3.497 & 3 & 1.905 \\
\hline 0.3 & 3.61 & 3.107 & 2.075 & 0.8666 & 3.497 & 2.993 & 1.899 \\
\hline 0.3033 & 3.61 & 3.1 & 2.075 & 0.8833 & 3.49 & 2.993 & 1.899 \\
\hline 0.3066 & 3.603 & 3.1 & 2.069 & 0.9 & 3.49 & 2.993 & 1.893 \\
\hline 0.31 & 3.603 & 3.1 & 2.069 & 0.9166 & 3.484 & 2.987 & 1.893 \\
\hline 0.3133 & 3.603 & 3.1 & 2.069 & 0.9333 & 3.484 & 2.987 & 1.886 \\
\hline 0.3166 & 3.603 & 3.1 & 2.069 & 0.95 & 3.478 & 2.981 & 1.88 \\
\hline 0.32 & 3.603 & 3.1 & 2.063 & 0.9666 & 3.478 & 2.975 & 1.874 \\
\hline 0.3233 & 3.603 & 3.1 & 2.069 & 0.9833 & 3.471 & 2.975 & 1.868 \\
\hline 0.3266 & 3.603 & 3.1 & 2.069 & 1 & 3.471 & 2.968 & 1.861 \\
\hline 0.33 & 3.603 & 3.1 & 2.063 & 1.2 & 3.44 & 2.937 & 1.817 \\
\hline 0.3333 & 3.603 & 3.094 & 2.063 & 1.4 & 3.408 & 2.899 & 1.754 \\
\hline 0.35 & 3.597 & 3.094 & 2.056 & 1.6 & 3.371 & 2.861 & 1.704 \\
\hline 0.3666 & 3.597 & 3.094 & 2.056 & 1.8 & 3.333 & 2.83 & 1.647 \\
\hline 0.3833 & 3.591 & 3.088 & 2.05 & 2 & 3.302 & 2.792 & 1.597 \\
\hline 0.4 & 3.591 & 3.088 & 2.044 & 2.2 & 3.264 & 2.754 & 1.553 \\
\hline 0.4166 & 3.585 & 3.081 & 2.037 & 2.4 & 3.232 & 2.673 & 1.503 \\
\hline 0.4333 & 3.578 & 3.081 & 2.031 & 2.6 & 3.201 & 2.597 & 1.452 \\
\hline 0.45 & 3.578 & 3.075 & 2.031 & 2.8 & 3.17 & 2.515 & 1.408 \\
\hline 0.4666 & 3.578 & 3.075 & 2.025 & 3 & 3.132 & 2.44 & 1.371 \\
\hline 0.4833 & 3.572 & 3.075 & 2.019 & 3.2 & 3.1 & 2.364 & 1.327 \\
\hline 0.5 & 3.566 & 3.069 & 2.012 & 3.4 & 3.063 & 2.295 & 1.283 \\
\hline 0.5166 & 3.566 & 3.069 & 2.006 & 3.6 & 3.031 & 2.226 & 1.245 \\
\hline 0.5333 & 3.566 & 3.063 & 2 & 3.8 & 2.993 & 2.157 & 1.207 \\
\hline 0.55 & 3.559 & 3.063 & 2 & 4 & 2.956 & 2.094 & 1.169 \\
\hline 0.5666 & 3.553 & 3.056 & 1.993 & 4.2 & 2.918 & 2.031 & 1.138 \\
\hline 0.5833 & 3.553 & 3.05 & 1.987 & 4.4 & 2.88 & 1.975 & 1.1 \\
\hline 0.6 & 3.547 & 3.05 & 1.981 & 4.6 & 2.842 & 1.912 & 1.069 \\
\hline 0.6166 & 3.547 & 3.044 & 1.981 & 4.8 & 2.811 & 1.855 & 1.037 \\
\hline 0.6333 & 3.541 & 3.044 & 1.975 & 5 & 2.78 & 1.798 & 1.006 \\
\hline 0.65 & 3.541 & 3.044 & 1.968 & 5.2 & 2.717 & 1.742 & 0.974 \\
\hline 0.6666 & 3.534 & 3.037 & 1.962 & 5.4 & 2.641 & 1.691 & 0.949 \\
\hline 0.6833 & 3.534 & 3.037 & 1.956 & 5.6 & 2.566 & 1.641 & 0.912 \\
\hline
\end{tabular}


TABLE A.8 (Cont.)

\begin{tabular}{|c|c|c|c|c|c|c|c|}
\hline \multirow[b]{2}{*}{$\begin{array}{c}\text { Elapsed } \\
\text { Time } \\
\text { (min) }\end{array}$} & \multicolumn{3}{|c|}{ Residual Drawdown (ft) } & \multirow[b]{2}{*}{$\begin{array}{c}\text { Elapsed } \\
\text { Time } \\
\text { (min) }\end{array}$} & \multicolumn{3}{|c|}{ Residual Drawdown (ft) } \\
\hline & $\begin{array}{l}\text { Test } 0 \\
\text { Step } 0\end{array}$ & $\begin{array}{l}\text { Test } 0 \\
\text { Step } 1\end{array}$ & $\begin{array}{l}\text { Test } 0 \\
\text { Step } 2\end{array}$ & & $\begin{array}{l}\text { Test } 0 \\
\text { Step } 0\end{array}$ & $\begin{array}{l}\text { Test } 0 \\
\text { Step } 1\end{array}$ & $\begin{array}{l}\text { Test } 0 \\
\text { Step } 2\end{array}$ \\
\hline 5.8 & 2.49 & 1.591 & 0.886 & 9.2 & 1.522 & 0.93 & 0.522 \\
\hline 6 & 2.421 & 1.541 & 0.861 & 9.4 & 1.478 & 0.905 & 0.503 \\
\hline 6.2 & 2.352 & 1.496 & 0.836 & 9.6 & 1.434 & 0.874 & 0.49 \\
\hline 6.4 & 2.283 & 1.446 & 0.811 & 9.8 & 1.39 & 0.849 & 0.471 \\
\hline 6.6 & 2.214 & 1.402 & 0.786 & 10 & 1.352 & 0.817 & 0.459 \\
\hline 6.8 & 2.151 & 1.358 & 0.761 & 12 & 1.012 & 0.591 & 0.333 \\
\hline 7 & 2.094 & 1.32 & 0.735 & 14 & 0.761 & 0.427 & 0.239 \\
\hline 7.2 & 2.031 & 1.276 & 0.717 & 16 & 0.566 & 0.301 & 0.169 \\
\hline 7.4 & 1.975 & 1.239 & 0.691 & 18 & 0.427 & 0.213 & 0.119 \\
\hline 7.6 & 1.918 & 1.201 & 0.666 & 20 & 0.32 & 0.15 & 0.075 \\
\hline 7.8 & 1.861 & 1.163 & 0.647 & 22 & 0.239 & 0.1 & 0.05 \\
\hline 8 & 1.811 & 1.125 & 0.628 & 24 & 0.182 & 0.069 & 0.025 \\
\hline 8.2 & 1.754 & 1.094 & 0.61 & 26 & 0.132 & & 0.012 \\
\hline 8.4 & 1.704 & 1.056 & 0.591 & 28 & 0.1 & & \\
\hline 8.6 & 1.66 & 1.025 & 0.572 & 30 & 0.069 & & \\
\hline 8.8 & 1.61 & 0.993 & 0.553 & 32 & 0.05 & & \\
\hline 9 & 1.566 & 0.962 & 0.54 & & & & \\
\hline
\end{tabular}


TABLE A.9 Slug test data for boring SB01 (effective saturated thickness $=10 \mathrm{ft}$ : length of well $=10 \mathrm{ft}$; length of screen $=10 \mathrm{ft}$; casing radius $=0.04167 \mathrm{ft}$; borehole radius $=0.05469 \mathrm{ft}$; $\mathrm{Kz} / \mathrm{Kr}=1)$.

\begin{tabular}{|c|c|c|c|c|c|c|c|c|}
\hline \multirow{2}{*}{$\begin{array}{c}\text { Elapsed } \\
\text { Time } \\
\text { (min) }\end{array}$} & \multicolumn{2}{|c|}{$\begin{array}{c}\text { Residual } \\
\text { Drawdown (ft) }\end{array}$} & \multirow{2}{*}{$\begin{array}{c}\text { Elapsed } \\
\text { Time } \\
\text { (min) }\end{array}$} & \multicolumn{2}{|c|}{$\begin{array}{c}\text { Residual } \\
\text { Drawdown (ft) }\end{array}$} & \multirow{2}{*}{$\begin{array}{c}\text { Elapsed } \\
\text { Time } \\
\text { (min) }\end{array}$} & \multicolumn{2}{|c|}{$\begin{array}{c}\text { Residual } \\
\text { Drawdown (ft) }\end{array}$} \\
\hline & $\begin{array}{l}\text { Slug } \\
\text { In }\end{array}$ & $\begin{array}{l}\text { Slug } \\
\text { Out }\end{array}$ & & $\begin{array}{l}\text { Slug } \\
\text { In }\end{array}$ & $\begin{array}{l}\text { Slug } \\
\text { Out }\end{array}$ & & $\begin{array}{l}\text { Slug } \\
\text { In }\end{array}$ & $\begin{array}{l}\text { Slug } \\
\text { Out }\end{array}$ \\
\hline 0 & & & 0.297 & 0.409 & 0.445 & 2.7863 & 0.368 & 0.403 \\
\hline 0.005 & 0.004 & & 0.3147 & 0.407 & 0.443 & 2.953 & 0.367 & 0.401 \\
\hline 0.01 & 0.006 & & 0.3333 & 0.407 & 0.443 & 3.1297 & 0.37 & 0.401 \\
\hline 0.015 & 0.008 & & 0.3532 & 0.405 & 0.443 & 3.3163 & 0.368 & 0.401 \\
\hline 0.02 & 0.008 & & 0.3742 & 0.402 & 0.441 & 3.5147 & 0.368 & 0.401 \\
\hline 0.025 & 0.008 & & 0.3963 & 0.402 & 0.439 & 3.7247 & 0.368 & 0.401 \\
\hline 0.03 & 0.008 & & 0.4198 & 0.4 & 0.437 & 3.9463 & 0.365 & 0.401 \\
\hline 0.035 & 0.01 & & 0.4447 & 0.4 & 0.437 & 4.1813 & 0.365 & 0.399 \\
\hline 0.04 & 0.01 & & 0.4697 & 0.398 & 0.434 & 4.4295 & 0.365 & 0.399 \\
\hline 0.045 & 0.01 & & 0.4963 & 0.398 & 0.434 & 4.693 & 0.365 & 0.399 \\
\hline 0.05 & 0.01 & & 0.5247 & 0.396 & 0.432 & 4.973 & 0.365 & 0.397 \\
\hline 0.055 & 0.01 & & 0.5547 & 0.394 & 0.43 & 5.2697 & 0.365 & 0.399 \\
\hline 0.06 & 0.01 & & 0.5863 & 0.394 & 0.43 & 5.583 & 0.363 & 0.397 \\
\hline 0.065 & 0.01 & 0.679 & 0.6213 & 0.394 & 0.428 & 5.9147 & 0.363 & 0.399 \\
\hline 0.07 & 0.01 & 0.215 & 0.6578 & 0.391 & 0.426 & 6.2663 & 0.363 & 0.397 \\
\hline 0.075 & 0.01 & 0.298 & 0.6963 & 0.389 & 0.426 & 6.6397 & 0.363 & 0.397 \\
\hline 0.08 & 0.012 & 0.371 & 0.738 & 0.389 & 0.426 & 7.0347 & 0.361 & 0.397 \\
\hline 0.0848 & 0.01 & 0.433 & 0.7813 & 0.387 & 0.423 & 7.453 & 0.361 & 0.397 \\
\hline 0.09 & 0.01 & 0.486 & 0.828 & 0.387 & 0.423 & 7.8963 & 0.361 & 0.397 \\
\hline 0.095 & 0.012 & 0.481 & 0.8763 & 0.385 & 0.421 & 8.3663 & 0.359 & 0.394 \\
\hline 0.1 & 0.014 & 0.472 & 0.928 & 0.385 & 0.419 & 8.8647 & 0.359 & 0.394 \\
\hline 0.1058 & 1.293 & 0.441 & 0.983 & 0.383 & 0.419 & 9.3913 & 0.361 & 0.394 \\
\hline 0.112 & & 0.472 & 1.0413 & 0.383 & 0.419 & 9.9497 & 0.359 & 0.394 \\
\hline 0.1185 & 0.164 & 0.444 & 1.103 & 0.38 & 0.417 & 10.5413 & 0.357 & 0.392 \\
\hline 0.1255 & 0.512 & 0.472 & 1.168 & 0.381 & 0.414 & 11.168 & 0.357 & 0.392 \\
\hline 0.1328 & 0.444 & 0.461 & 1.238 & 0.378 & 0.414 & 11.8313 & 0.357 & 0.392 \\
\hline 0.1407 & 0.417 & 0.457 & 1.3113 & 0.378 & 0.412 & 12.5347 & 0.354 & 0.392 \\
\hline 0.149 & 0.422 & 0.455 & 1.3897 & 0.376 & 0.412 & 13.2797 & 0.352 & 0.392 \\
\hline 0.1578 & 0.424 & 0.459 & 1.473 & 0.374 & 0.41 & 14.0697 & 0.352 & 0.392 \\
\hline 0.167 & 0.422 & 0.468 & 1.5613 & 0.374 & 0.41 & 14.9063 & 0.352 & 0.392 \\
\hline 0.177 & 0.422 & 0.459 & 1.6547 & 0.374 & 0.41 & 15.7913 & 0.352 & 0.392 \\
\hline 0.1875 & 0.418 & 0.457 & 1.753 & 0.374 & 0.408 & 16.7297 & 0.35 & 0.39 \\
\hline 0.1985 & 0.418 & 0.454 & 1.858 & 0.372 & 0.408 & 17.723 & 0.35 & 0.392 \\
\hline 0.2102 & 0.415 & 0.452 & 1.968 & 0.372 & 0.405 & 18.7763 & 0.35 & 0.392 \\
\hline 0.2227 & 0.415 & 0.452 & 2.0847 & 0.372 & 0.405 & 19.8913 & 0.346 & 0.392 \\
\hline 0.2358 & 0.415 & 0.45 & 2.2097 & 0.37 & 0.403 & 21.073 & 0.346 & 0.392 \\
\hline 0.2498 & 0.413 & 0.45 & 2.3412 & 0.37 & 0.405 & 22.3247 & 0.346 & 0.39 \\
\hline 0.2647 & 0.411 & 0.445 & 2.4813 & 0.37 & 0.403 & 23.6497 & 0.343 & 0.39 \\
\hline 0.2803 & 0.411 & 0.445 & 2.6297 & 0.367 & 0.401 & 25.0547 & 0.341 & 0.39 \\
\hline
\end{tabular}


TABLE A.9 (Cont.)

\begin{tabular}{|c|c|c|c|c|c|c|c|c|}
\hline \multirow{2}{*}{$\begin{array}{c}\text { Elapsed } \\
\text { Time } \\
\text { (min) }\end{array}$} & \multicolumn{2}{|c|}{$\begin{array}{c}\text { Residual } \\
\text { Drawdown (ft) }\end{array}$} & \multirow{2}{*}{$\begin{array}{c}\text { Elapsed } \\
\text { Time } \\
\text { (min) }\end{array}$} & \multicolumn{2}{|c|}{$\begin{array}{c}\text { Residual } \\
\text { Drawdown (ft) }\end{array}$} & \multirow{2}{*}{$\begin{array}{c}\text { Elapsed } \\
\text { Time } \\
\text { (min) }\end{array}$} & \multicolumn{2}{|c|}{$\begin{array}{c}\text { Residual } \\
\text { Drawdown (ft) }\end{array}$} \\
\hline & $\begin{array}{l}\text { Slug } \\
\text { In }\end{array}$ & $\begin{array}{l}\text { Slug } \\
\text { Out }\end{array}$ & & $\begin{array}{l}\text { Slug } \\
\text { In }\end{array}$ & $\begin{array}{l}\text { Slug } \\
\text { Out }\end{array}$ & & $\begin{array}{l}\text { Slug } \\
\text { In }\end{array}$ & $\begin{array}{l}\text { Slug } \\
\text { Out }\end{array}$ \\
\hline 26.543 & 0.341 & 0.388 & 258.2747 & & 0.364 & 668.2747 & & 0.357 \\
\hline 28.118 & 0.339 & 0.39 & 268.2747 & & 0.364 & 678.2747 & & 0.357 \\
\hline 29.7863 & 0.339 & 0.388 & 278.2747 & & 0.364 & 688.2747 & & 0.355 \\
\hline 31.5547 & 0.337 & 0.388 & 288.2747 & & 0.361 & 698.2747 & & 0.355 \\
\hline 33.428 & 0.335 & 0.388 & 298.2747 & & 0.361 & 708.2747 & & 0.357 \\
\hline 35.4112 & 0.332 & 0.386 & 308.2747 & & 0.361 & 718.2747 & & 0.355 \\
\hline 37.513 & 0.33 & 0.388 & 318.2747 & & 0.361 & 728.2747 & & 0.355 \\
\hline 39.7397 & 0.328 & 0.388 & 328.2747 & & 0.359 & 738.2747 & & 0.355 \\
\hline 42.098 & 0.326 & 0.388 & 338.2747 & & 0.359 & 748.2747 & & 0.353 \\
\hline 44.5963 & 0.324 & 0.386 & 348.2747 & & 0.361 & 758.2747 & & 0.355 \\
\hline 47.243 & 0.319 & 0.386 & 358.2747 & & 0.361 & 768.2747 & & 0.355 \\
\hline 50.0463 & 0.319 & 0.383 & 368.2747 & & 0.361 & 778.2747 & & 0.355 \\
\hline 53.0147 & 0.317 & 0.383 & 378.2747 & & 0.361 & 788.2747 & & 0.353 \\
\hline 56.1597 & 0.313 & 0.383 & 388.2747 & & 0.361 & 798.2747 & & 0.35 \\
\hline 59.4913 & 0.308 & 0.383 & 398.2747 & & 0.361 & 808.2747 & & 0.35 \\
\hline 63.0197 & 0.308 & 0.379 & 408.2747 & & 0.361 & 818.2747 & & 0.353 \\
\hline 66.758 & 0.304 & 0.381 & 418.2747 & & 0.361 & 828.2747 & & 0.348 \\
\hline 70.718 & 0.302 & 0.381 & 428.2747 & & 0.361 & 838.2747 & & 0.35 \\
\hline 74.9113 & 0.297 & 0.381 & 438.2747 & & 0.361 & 848.2747 & & 0.348 \\
\hline 79.3547 & 0.295 & 0.379 & 448.2747 & & 0.361 & 858.2747 & & 0.348 \\
\hline 84.0613 & 0.291 & 0.379 & 458.2747 & & 0.359 & 868.2747 & & 0.348 \\
\hline 89.0463 & 0.286 & 0.377 & 468.2747 & & 0.359 & 878.2747 & & 0.348 \\
\hline 94.3263 & 0.282 & 0.379 & 478.2747 & & 0.359 & 888.2747 & & 0.348 \\
\hline 99.9197 & 0.277 & 0.375 & 488.2747 & & 0.359 & 898.2747 & & 0.346 \\
\hline 105.8447 & 0.273 & 0.375 & 498.2747 & & 0.361 & 908.2747 & & 0.346 \\
\hline 112.1197 & 0.269 & 0.375 & 508.2747 & & 0.361 & 918.2747 & & 0.346 \\
\hline 118.768 & 0.262 & 0.375 & 518.2747 & & 0.361 & 928.2747 & & 0.346 \\
\hline 125.8097 & 0.258 & 0.375 & 528.2747 & & 0.361 & 938.2747 & & 0.346 \\
\hline 133.268 & 0.253 & 0.372 & 538.2747 & & 0.361 & 948.2747 & & 0.344 \\
\hline 141.168 & 0.249 & 0.372 & 548.2747 & & 0.361 & 958.2747 & & 0.344 \\
\hline 149.5363 & 0.24 & 0.37 & 558.2747 & & 0.359 & 968.2747 & & 0.344 \\
\hline 158.4013 & 0.236 & 0.37 & 568.2747 & & 0.359 & 978.2747 & & 0.344 \\
\hline 167.7913 & 0.229 & 0.368 & 578.2747 & & 0.359 & 988.2747 & & 0.344 \\
\hline 177.738 & 0.222 & 0.37 & 588.2747 & & 0.359 & 998.2747 & & 0.342 \\
\hline 188.2747 & 0.216 & 0.368 & 598.2747 & & 0.359 & 1008.2747 & & 0.344 \\
\hline 198.2747 & 0.209 & 0.368 & 608.2747 & & 0.359 & 1018.2747 & & 0.344 \\
\hline 208.2747 & 0.205 & 0.368 & 618.2747 & & 0.359 & 1028.2747 & & 0.344 \\
\hline 218.2747 & 0.198 & 0.368 & 628.2747 & & 0.359 & 1038.2747 & & 0.342 \\
\hline 228.2747 & 0.192 & 0.366 & 638.2747 & & 0.357 & 1048.2747 & & 0.342 \\
\hline 238.2747 & 0.189 & 0.366 & 648.2747 & & 0.357 & 1058.2747 & & 0.342 \\
\hline 248.2747 & & 0.366 & 658.2747 & & 0.357 & 1068.2747 & & 0.342 \\
\hline
\end{tabular}




\begin{tabular}{ccc} 
TABLE A.9 & (Cont.) \\
\hline & \multicolumn{2}{c}{$\begin{array}{c}\text { Residual } \\
\text { Drawdown (ft) }\end{array}$} \\
\cline { 2 - 3 } $\begin{array}{c}\text { Elapsed } \\
\text { Time } \\
\text { (min) }\end{array}$ & $\begin{array}{c}\text { Slug } \\
\text { In }\end{array}$ & $\begin{array}{c}\text { Slug } \\
\text { Out }\end{array}$ \\
& & \\
\hline & & \\
1078.2747 & & 0.342 \\
1088.2747 & & 0.342 \\
1098.2747 & & 0.339 \\
1108.2747 & & 0.342 \\
1118.2747 & & 0.339 \\
1128.2747 & & 0.339 \\
1138.2747 & & 0.339 \\
1148.2747 & & 0.337 \\
1158.2747 & & 0.337 \\
1168.2747 & & 0.339 \\
\hline
\end{tabular}


TABLE A.10 Slug test data for boring SB04 (effective saturated thickness $=10 \mathrm{ft}$ : length of well $=10 \mathrm{ft}$; length of screen $=10 \mathrm{ft}$; casing radius $=0.04167 \mathrm{ft}$; borehole radius $=0.05469 \mathrm{ft} ; \mathrm{Kz} / \mathrm{Kr}=1)$.

\begin{tabular}{|c|c|c|c|c|c|c|c|}
\hline \multirow{2}{*}{$\begin{array}{c}\text { Elapsed } \\
\text { Time } \\
\text { (min) }\end{array}$} & \multicolumn{3}{|c|}{ Residual Drawdown (ft) } & \multirow{2}{*}{$\begin{array}{c}\text { Elapsed } \\
\text { Time } \\
\text { (min) }\end{array}$} & \multicolumn{3}{|c|}{ Residual Drawdown (ft) } \\
\hline & $\begin{array}{l}\text { Test } 1 \\
\text { Step } 0\end{array}$ & $\begin{array}{l}\text { Test } 1 \\
\text { Step } 1\end{array}$ & $\begin{array}{l}\text { Test } 1 \\
\text { Step } 2\end{array}$ & & $\begin{array}{l}\text { Test } 1 \\
\text { Step } 0\end{array}$ & $\begin{array}{l}\text { Test } 1 \\
\text { Step } 1\end{array}$ & $\begin{array}{l}\text { Test } 1 \\
\text { Step } 2\end{array}$ \\
\hline 0 & 6.274 & 5.858 & 6.601 & 0.1333 & 0.195 & 0.686 & 0.868 \\
\hline 0.0033 & 7.129 & 6.947 & 7.236 & 0.1366 & 0.176 & 0.648 & 0.824 \\
\hline 0.0066 & 6.771 & 6.827 & 6.897 & 0.14 & 0.163 & 0.61 & 0.78 \\
\hline 0.01 & 6.324 & 6.374 & 6.425 & 0.1433 & 0.151 & 0.579 & 0.742 \\
\hline 0.0133 & 5.701 & 5.682 & 5.871 & 0.1466 & 0.144 & 0.547 & 0.704 \\
\hline 0.0166 & 5.16 & 5.173 & 5.468 & 0.15 & 0.132 & 0.516 & 0.667 \\
\hline 0.02 & 4.694 & 4.839 & 5.154 & 0.1533 & 0.125 & 0.49 & 0.635 \\
\hline 0.0233 & 4.241 & 4.543 & 4.864 & 0.1566 & 0.119 & 0.459 & 0.604 \\
\hline 0.0266 & 3.857 & 4.273 & 4.631 & 0.16 & 0.113 & 0.434 & 0.572 \\
\hline 0.03 & 3.511 & 4.027 & 4.399 & 0.1633 & 0.107 & 0.415 & 0.541 \\
\hline 0.0333 & 3.197 & 3.801 & 4.178 & 0.1666 & 0.1 & 0.39 & 0.516 \\
\hline 0.0366 & 2.913 & 3.587 & 3.971 & 0.17 & 0.094 & 0.371 & 0.484 \\
\hline 0.04 & 2.649 & 3.385 & 3.776 & 0.1733 & 0.088 & 0.352 & 0.465 \\
\hline 0.0433 & 2.416 & 3.203 & 3.581 & 0.1766 & 0.088 & 0.333 & 0.44 \\
\hline 0.0466 & 2.202 & 3.02 & 3.404 & 0.18 & 0.081 & 0.321 & 0.415 \\
\hline 0.05 & 2.007 & 2.857 & 3.234 & 0.1833 & 0.075 & 0.302 & 0.396 \\
\hline 0.0533 & 1.825 & 2.7 & 3.071 & 0.1866 & 0.075 & 0.289 & 0.377 \\
\hline 0.0566 & 1.661 & 2.549 & 2.92 & 0.19 & 0.075 & 0.27 & 0.358 \\
\hline 0.06 & 1.51 & 2.41 & 2.775 & 0.1933 & 0.069 & 0.258 & 0.34 \\
\hline 0.0633 & 1.372 & 2.278 & 2.637 & 0.1966 & 0.069 & 0.245 & 0.327 \\
\hline 0.0666 & 1.246 & 2.152 & 2.498 & 0.2 & 0.069 & 0.239 & 0.308 \\
\hline 0.07 & 1.132 & 2.032 & 2.372 & 0.2033 & 0.063 & 0.226 & 0.295 \\
\hline 0.0733 & 1.025 & 1.919 & 2.253 & 0.2066 & 0.063 & 0.214 & 0.283 \\
\hline 0.0766 & 0.931 & 1.812 & 2.139 & 0.21 & 0.063 & 0.207 & 0.27 \\
\hline 0.08 & 0.843 & 1.711 & 2.032 & 0.2133 & 0.056 & 0.195 & 0.258 \\
\hline 0.0833 & 0.767 & 1.617 & 1.925 & 0.2166 & 0.056 & 0.188 & 0.245 \\
\hline 0.0866 & 0.692 & 1.529 & 1.831 & 0.22 & 0.056 & 0.176 & 0.232 \\
\hline 0.09 & 0.629 & 1.441 & 1.737 & 0.2233 & 0.056 & 0.17 & 0.22 \\
\hline 0.0933 & 0.572 & 1.359 & 1.642 & 0.2266 & 0.05 & 0.163 & 0.214 \\
\hline 0.0966 & 0.516 & 1.284 & 1.56 & 0.23 & 0.05 & 0.157 & 0.201 \\
\hline 0.1 & 0.472 & 1.214 & 1.479 & 0.2333 & 0.05 & 0.151 & 0.195 \\
\hline 0.1033 & 0.428 & 1.145 & 1.403 & 0.2366 & 0.05 & 0.144 & 0.188 \\
\hline 0.1066 & 0.39 & 1.082 & 1.334 & 0.24 & 0.05 & 0.138 & 0.176 \\
\hline 0.11 & 0.352 & 1.025 & 1.265 & 0.2433 & 0.05 & 0.132 & 0.17 \\
\hline 0.1133 & 0.321 & 0.963 & 1.195 & 0.2466 & 0.05 & 0.125 & 0.163 \\
\hline 0.1166 & 0.295 & 0.912 & 1.132 & 0.25 & 0.044 & 0.125 & 0.157 \\
\hline 0.12 & 0.27 & 0.862 & 1.076 & 0.2533 & 0.044 & 0.119 & 0.151 \\
\hline 0.1233 & 0.245 & 0.811 & 1.019 & 0.2566 & 0.044 & 0.113 & 0.144 \\
\hline 0.1266 & 0.226 & 0.767 & 0.969 & 0.26 & 0.044 & 0.113 & 0.138 \\
\hline 0.13 & 0.207 & 0.723 & 0.918 & 0.2633 & 0.044 & 0.107 & 0.138 \\
\hline
\end{tabular}


TABLE A.10 (Cont.)

\begin{tabular}{|c|c|c|c|c|c|c|c|}
\hline \multirow{2}{*}{$\begin{array}{c}\text { Elapsed } \\
\text { Time } \\
\text { (min) }\end{array}$} & \multicolumn{3}{|c|}{ Residual Drawdown (ft) } & \multirow{2}{*}{$\begin{array}{c}\text { Elapsed } \\
\text { Time } \\
\text { (min) }\end{array}$} & \multicolumn{3}{|c|}{ Residual Drawdown (ft) } \\
\hline & $\begin{array}{l}\text { Test } 1 \\
\text { Step } 0\end{array}$ & $\begin{array}{l}\text { Test } 1 \\
\text { Step } 1\end{array}$ & $\begin{array}{l}\text { Test } 1 \\
\text { Step } 2\end{array}$ & & $\begin{array}{l}\text { Test } 1 \\
\text { Step } 0\end{array}$ & $\begin{array}{l}\text { Test } 1 \\
\text { Step } 1\end{array}$ & $\begin{array}{l}\text { Test } 1 \\
\text { Step } 2\end{array}$ \\
\hline 0.2666 & 0.044 & 0.107 & 0.132 & 0.7 & 0.018 & 0.025 & 0.031 \\
\hline 0.27 & 0.037 & 0.1 & 0.125 & 0.7166 & 0.018 & 0.025 & 0.031 \\
\hline 0.2733 & 0.044 & 0.1 & 0.119 & 0.7333 & 0.018 & 0.031 & 0.025 \\
\hline 0.2766 & 0.037 & 0.094 & 0.119 & 0.75 & 0.018 & 0.031 & 0.025 \\
\hline 0.28 & 0.037 & 0.094 & 0.113 & 0.7666 & 0.012 & 0.025 & 0.025 \\
\hline 0.2833 & 0.037 & 0.088 & 0.107 & 0.7833 & 0.012 & 0.031 & 0.025 \\
\hline 0.2866 & 0.037 & 0.088 & 0.107 & 0.8 & 0.018 & 0.031 & 0.025 \\
\hline 0.29 & 0.037 & 0.081 & 0.1 & 0.8166 & 0.012 & 0.031 & 0.025 \\
\hline 0.2933 & 0.037 & 0.081 & 0.1 & 0.8333 & 0.018 & 0.031 & 0.025 \\
\hline 0.2966 & 0.037 & 0.081 & 0.094 & 0.85 & 0.012 & 0.031 & 0.025 \\
\hline 0.3 & 0.037 & 0.075 & 0.094 & 0.8666 & 0.012 & 0.031 & 0.025 \\
\hline 0.3033 & 0.037 & 0.075 & 0.088 & 0.8833 & 0.012 & 0.031 & 0.025 \\
\hline 0.3066 & 0.031 & 0.075 & 0.088 & 0.9 & 0.012 & 0.031 & 0.025 \\
\hline 0.31 & 0.037 & 0.075 & 0.088 & 0.9166 & 0.012 & 0.031 & 0.025 \\
\hline 0.3133 & 0.037 & 0.069 & 0.088 & 0.9333 & 0.012 & 0.031 & 0.025 \\
\hline 0.3166 & 0.031 & 0.069 & 0.081 & 0.95 & 0.012 & 0.025 & 0.025 \\
\hline 0.32 & 0.031 & 0.069 & 0.081 & 0.9666 & 0.012 & 0.031 & 0.025 \\
\hline 0.3233 & 0.031 & 0.069 & 0.075 & 0.9833 & 0.012 & 0.031 & 0.025 \\
\hline 0.3266 & 0.031 & 0.069 & 0.075 & 1 & 0.012 & 0.031 & 0.025 \\
\hline 0.33 & 0.031 & 0.063 & 0.075 & 1.2 & 0.012 & 0.025 & 0.025 \\
\hline 0.3333 & 0.031 & 0.063 & 0.069 & 1.4 & 0.012 & 0.025 & 0.025 \\
\hline 0.35 & 0.031 & 0.056 & 0.063 & 1.6 & 0.012 & 0.025 & 0.018 \\
\hline 0.3666 & 0.031 & 0.05 & 0.056 & 1.8 & 0.012 & 0.025 & 0.025 \\
\hline 0.3833 & 0.025 & 0.05 & 0.05 & 2 & 0.012 & 0.025 & 0.025 \\
\hline 0.4 & 0.025 & 0.05 & 0.05 & 2.2 & 0.012 & 0.025 & 0.025 \\
\hline 0.4166 & 0.025 & 0.044 & 0.044 & 2.4 & 0.012 & 0.025 & 0.025 \\
\hline 0.4333 & 0.025 & 0.044 & 0.044 & 2.6 & 0.012 & 0.025 & 0.025 \\
\hline 0.45 & 0.025 & 0.037 & 0.044 & 2.8 & 0.012 & 0.025 & 0.025 \\
\hline 0.4666 & 0.025 & 0.037 & 0.037 & 3 & 0.012 & 0.025 & 0.018 \\
\hline 0.4833 & 0.025 & 0.037 & 0.037 & 3.2 & 0.012 & 0.025 & 0.025 \\
\hline 0.5 & 0.018 & 0.044 & 0.037 & 3.4 & 0.012 & 0.025 & 0.018 \\
\hline 0.5166 & 0.018 & 0.037 & 0.031 & 3.6 & 0.012 & 0.025 & 0.018 \\
\hline 0.5333 & 0.018 & 0.037 & 0.031 & 3.8 & 0.012 & 0.025 & 0.025 \\
\hline 0.55 & 0.018 & 0.037 & 0.037 & 4 & 0.012 & 0.025 & 0.018 \\
\hline 0.5666 & 0.018 & 0.037 & 0.031 & 4.2 & 0.012 & 0.025 & 0.025 \\
\hline 0.5833 & 0.018 & 0.037 & 0.031 & 4.4 & 0.012 & 0.025 & 0.025 \\
\hline 0.6 & 0.018 & 0.037 & 0.031 & 4.6 & 0.012 & 0.025 & 0.025 \\
\hline 0.6166 & 0.018 & 0.031 & 0.031 & 4.8 & 0.012 & 0.025 & 0.018 \\
\hline 0.6333 & 0.018 & 0.031 & 0.031 & 5 & 0.012 & 0.025 & 0.018 \\
\hline 0.65 & 0.018 & 0.031 & 0.031 & 5.2 & 0.012 & 0.025 & 0.018 \\
\hline 0.6666 & 0.018 & 0.031 & 0.031 & 5.4 & 0.012 & 0.025 & 0.025 \\
\hline 0.6833 & 0.018 & 0.031 & 0.025 & 5.6 & 0.012 & 0.025 & 0.025 \\
\hline
\end{tabular}


TABLE A.10 (Cont.)

\begin{tabular}{|c|c|c|c|c|c|c|c|}
\hline \multirow{2}{*}{$\begin{array}{c}\text { Elapsed } \\
\text { Time } \\
\text { (min) }\end{array}$} & \multicolumn{3}{|c|}{ Residual Drawdown (ft) } & \multirow{2}{*}{$\begin{array}{c}\text { Elapsed } \\
\text { Time } \\
\text { (min) }\end{array}$} & \multicolumn{3}{|c|}{ Residual Drawdown (ft) } \\
\hline & $\begin{array}{l}\text { Test } 1 \\
\text { Step } 0\end{array}$ & $\begin{array}{l}\text { Test } 1 \\
\text { Step } 1\end{array}$ & $\begin{array}{l}\text { Test } 1 \\
\text { Step } 2\end{array}$ & & $\begin{array}{l}\text { Test } 1 \\
\text { Step } 0\end{array}$ & $\begin{array}{l}\text { Test } 1 \\
\text { Step } 1\end{array}$ & $\begin{array}{l}\text { Test } 1 \\
\text { Step } 2\end{array}$ \\
\hline 5.8 & 0.012 & 0.025 & 0.025 & 8 & 0.006 & 0.025 & 0.025 \\
\hline 6 & 0.012 & 0.025 & 0.025 & 8.2 & 0.006 & 0.025 & 0.025 \\
\hline 6.2 & 0.006 & 0.025 & 0.018 & 8.4 & 0.006 & 0.025 & 0.025 \\
\hline 6.4 & 0.012 & 0.025 & 0.025 & 8.6 & 0.012 & 0.025 & 0.025 \\
\hline 6.6 & 0.012 & 0.025 & 0.025 & 8.8 & 0.006 & 0.025 & 0.025 \\
\hline 6.8 & 0.012 & 0.025 & 0.025 & 9 & 0.006 & 0.025 & 0.025 \\
\hline 7 & 0.012 & 0.025 & 0.018 & 9.2 & 0.006 & 0.025 & 0.025 \\
\hline 7.2 & 0.012 & 0.025 & 0.025 & 9.4 & 0.012 & 0.025 & 0.025 \\
\hline 7.4 & 0.006 & 0.025 & 0.025 & 9.6 & 0.006 & 0.025 & 0.025 \\
\hline 7.6 & 0.006 & 0.025 & 0.025 & 9.8 & 0.006 & 0.025 & 0.025 \\
\hline 7.8 & 0.006 & 0.025 & 0.025 & 10 & 0.006 & 0.025 & 0.025 \\
\hline
\end{tabular}


TABLE A.11 Slug test data for boring SB05 (effective saturated thickness $=10 \mathrm{ft}$ : length of well $=10 \mathrm{ft}$; length of screen $=10 \mathrm{ft}$; casing radius $=0.04167 \mathrm{ft}$; borehole radius $=0.05469 \mathrm{ft} ; \mathrm{Kz} / \mathrm{Kr}=1)$.

\begin{tabular}{|c|c|c|c|c|c|c|c|}
\hline \multirow{2}{*}{$\begin{array}{c}\text { Elapsed } \\
\text { Time } \\
\text { (min) }\end{array}$} & \multicolumn{3}{|c|}{ Residual Drawdown (ft) } & \multirow{2}{*}{$\begin{array}{c}\text { Elapsed } \\
\text { Time } \\
\text { (min) }\end{array}$} & \multicolumn{3}{|c|}{ Residual Drawdown (ft) } \\
\hline & $\begin{array}{l}\text { Test } 5 \\
\text { Step } 0\end{array}$ & $\begin{array}{l}\text { Test } 5 \\
\text { Step } 1\end{array}$ & $\begin{array}{l}\text { Test } 5 \\
\text { Step } 2\end{array}$ & & $\begin{array}{l}\text { Test } 5 \\
\text { Step } 0\end{array}$ & $\begin{array}{l}\text { Test } 5 \\
\text { Step } 1\end{array}$ & $\begin{array}{l}\text { Test } 5 \\
\text { Step } 2\end{array}$ \\
\hline 0 & 3.896 & 4.248 & 4.909 & 0.1333 & 0.616 & 0.61 & 0.938 \\
\hline 0.0033 & 4.613 & 4.657 & 6.104 & 0.1366 & 0.591 & 0.585 & 0.906 \\
\hline 0.0066 & 4.657 & 4.481 & 5.79 & 0.14 & 0.566 & 0.566 & 0.868 \\
\hline 0.01 & 4.342 & 4.154 & 5.299 & 0.1433 & 0.547 & 0.541 & 0.837 \\
\hline 0.0133 & 3.959 & 3.852 & 4.871 & 0.1466 & 0.528 & 0.522 & 0.812 \\
\hline 0.0166 & 3.625 & 3.594 & 4.537 & 0.15 & 0.509 & 0.503 & 0.78 \\
\hline 0.02 & 3.361 & 3.367 & 4.273 & 0.1533 & 0.491 & 0.484 & 0.755 \\
\hline 0.0233 & 3.134 & 3.159 & 4.04 & 0.1566 & 0.478 & 0.465 & 0.723 \\
\hline 0.0266 & 2.939 & 2.97 & 3.839 & 0.16 & 0.459 & 0.453 & 0.698 \\
\hline 0.03 & 2.763 & 2.794 & 3.656 & 0.1633 & 0.447 & 0.434 & 0.679 \\
\hline 0.0333 & 2.612 & 2.643 & 3.487 & 0.1666 & 0.434 & 0.421 & 0.654 \\
\hline 0.0366 & 2.473 & 2.498 & 3.329 & 0.17 & 0.421 & 0.409 & 0.635 \\
\hline 0.04 & 2.347 & 2.366 & 3.178 & 0.1733 & 0.403 & 0.396 & 0.616 \\
\hline 0.0433 & 2.228 & 2.247 & 3.04 & 0.1766 & 0.396 & 0.384 & 0.598 \\
\hline 0.0466 & 2.114 & 2.133 & 2.901 & 0.18 & 0.384 & 0.371 & 0.579 \\
\hline 0.05 & 2.008 & 2.026 & 2.769 & 0.1833 & 0.371 & 0.358 & 0.56 \\
\hline 0.0533 & 1.901 & 1.926 & 2.643 & 0.1866 & 0.365 & 0.352 & 0.547 \\
\hline 0.0566 & 1.806 & 1.825 & 2.524 & 0.19 & 0.352 & 0.34 & 0.528 \\
\hline 0.06 & 1.712 & 1.737 & 2.41 & 0.1933 & 0.346 & 0.333 & 0.516 \\
\hline 0.0633 & 1.63 & 1.649 & 2.303 & 0.1966 & 0.333 & 0.321 & 0.503 \\
\hline 0.0666 & 1.548 & 1.567 & 2.203 & 0.2 & 0.327 & 0.314 & 0.491 \\
\hline 0.07 & 1.473 & 1.485 & 2.102 & 0.2033 & 0.321 & 0.308 & 0.478 \\
\hline 0.0733 & 1.397 & 1.416 & 2.008 & 0.2066 & 0.314 & 0.302 & 0.465 \\
\hline 0.0766 & 1.328 & 1.34 & 1.919 & 0.21 & 0.308 & 0.289 & 0.453 \\
\hline 0.08 & 1.265 & 1.277 & 1.838 & 0.2133 & 0.302 & 0.283 & 0.44 \\
\hline 0.0833 & 1.202 & 1.214 & 1.756 & 0.2166 & 0.295 & 0.277 & 0.434 \\
\hline 0.0866 & 1.145 & 1.158 & 1.68 & 0.22 & 0.289 & 0.27 & 0.421 \\
\hline 0.09 & 1.089 & 1.101 & 1.611 & 0.2233 & 0.283 & 0.27 & 0.415 \\
\hline 0.0933 & 1.038 & 1.044 & 1.542 & 0.2266 & 0.277 & 0.264 & 0.403 \\
\hline 0.0966 & 0.994 & 1 & 1.479 & 0.23 & 0.277 & 0.258 & 0.396 \\
\hline 0.1 & 0.944 & 0.95 & 1.416 & 0.2333 & 0.27 & 0.251 & 0.39 \\
\hline 0.1033 & 0.906 & 0.906 & 1.353 & 0.2366 & 0.264 & 0.251 & 0.377 \\
\hline 0.1066 & 0.862 & 0.868 & 1.296 & 0.24 & 0.264 & 0.245 & 0.377 \\
\hline 0.11 & 0.824 & 0.824 & 1.246 & 0.2433 & 0.258 & 0.239 & 0.365 \\
\hline 0.1133 & 0.786 & 0.793 & 1.196 & 0.2466 & 0.251 & 0.239 & 0.358 \\
\hline 0.1166 & 0.755 & 0.755 & 1.145 & 0.25 & 0.251 & 0.233 & 0.352 \\
\hline 0.12 & 0.723 & 0.723 & 1.101 & 0.2533 & 0.245 & 0.226 & 0.346 \\
\hline 0.1233 & 0.692 & 0.692 & 1.057 & 0.2566 & 0.245 & 0.226 & 0.34 \\
\hline 0.1266 & 0.667 & 0.667 & 1.013 & 0.26 & 0.239 & 0.22 & 0.333 \\
\hline 0.13 & 0.642 & 0.635 & 0.975 & 0.2633 & 0.239 & 0.22 & 0.333 \\
\hline
\end{tabular}


TABLE A.11 (Cont.)

\begin{tabular}{|c|c|c|c|c|c|c|c|}
\hline \multirow{2}{*}{$\begin{array}{c}\text { Elapsed } \\
\text { Time } \\
\text { (min) }\end{array}$} & \multicolumn{3}{|c|}{ Residual Drawdown (ft) } & \multirow{2}{*}{$\begin{array}{c}\text { Elapsed } \\
\text { Time } \\
\text { (min) }\end{array}$} & \multicolumn{3}{|c|}{ Residual Drawdown (ft) } \\
\hline & $\begin{array}{l}\text { Test } 5 \\
\text { Step } 0\end{array}$ & $\begin{array}{l}\text { Test } 5 \\
\text { Step } 1\end{array}$ & $\begin{array}{l}\text { Test } 5 \\
\text { Step } 2\end{array}$ & & $\begin{array}{l}\text { Test } 5 \\
\text { Step } 0\end{array}$ & $\begin{array}{l}\text { Test } 5 \\
\text { Step } 1\end{array}$ & $\begin{array}{l}\text { Test } 5 \\
\text { Step } 2\end{array}$ \\
\hline 0.2666 & 0.233 & 0.214 & 0.327 & 0.7 & 0.125 & 0.107 & 0.163 \\
\hline 0.27 & 0.233 & 0.214 & 0.321 & 0.7166 & 0.125 & 0.107 & 0.163 \\
\hline 0.2733 & 0.226 & 0.207 & 0.314 & 0.7333 & 0.119 & 0.107 & 0.157 \\
\hline 0.2766 & 0.226 & 0.207 & 0.308 & 0.75 & 0.119 & 0.107 & 0.157 \\
\hline 0.28 & 0.22 & 0.207 & 0.308 & 0.7666 & 0.119 & 0.107 & 0.157 \\
\hline 0.2833 & 0.22 & 0.201 & 0.302 & 0.7833 & 0.119 & 0.101 & 0.151 \\
\hline 0.2866 & 0.22 & 0.201 & 0.302 & 0.8 & 0.113 & 0.101 & 0.151 \\
\hline 0.29 & 0.214 & 0.201 & 0.295 & 0.8166 & 0.113 & 0.101 & 0.151 \\
\hline 0.2933 & 0.214 & 0.195 & 0.289 & 0.8333 & 0.113 & 0.101 & 0.151 \\
\hline 0.2966 & 0.214 & 0.195 & 0.289 & 0.85 & 0.113 & 0.101 & 0.144 \\
\hline 0.3 & 0.214 & 0.195 & 0.283 & 0.8666 & 0.113 & 0.094 & 0.144 \\
\hline 0.3033 & 0.207 & 0.188 & 0.283 & 0.8833 & 0.113 & 0.094 & 0.144 \\
\hline 0.3066 & 0.207 & 0.188 & 0.277 & 0.9 & 0.107 & 0.094 & 0.144 \\
\hline 0.31 & 0.207 & 0.188 & 0.277 & 0.9166 & 0.107 & 0.094 & 0.144 \\
\hline 0.3133 & 0.207 & 0.182 & 0.27 & 0.9333 & 0.107 & 0.094 & 0.138 \\
\hline 0.3166 & 0.201 & 0.182 & 0.27 & 0.95 & 0.107 & 0.094 & 0.138 \\
\hline 0.32 & 0.201 & 0.182 & 0.27 & 0.9666 & 0.107 & 0.088 & 0.138 \\
\hline 0.3233 & 0.201 & 0.182 & 0.264 & 0.9833 & 0.107 & 0.088 & 0.138 \\
\hline 0.3266 & 0.201 & 0.176 & 0.264 & 1 & 0.107 & 0.088 & 0.138 \\
\hline 0.33 & 0.195 & 0.176 & 0.258 & 1.2 & 0.094 & 0.081 & 0.125 \\
\hline 0.3333 & 0.195 & 0.176 & 0.258 & 1.4 & 0.088 & 0.075 & 0.113 \\
\hline 0.35 & 0.188 & 0.17 & 0.245 & 1.6 & 0.081 & 0.069 & 0.107 \\
\hline 0.3666 & 0.182 & 0.163 & 0.239 & 1.8 & 0.075 & 0.063 & 0.101 \\
\hline 0.3833 & 0.176 & 0.157 & 0.233 & 2 & 0.075 & 0.063 & 0.094 \\
\hline 0.4 & 0.17 & 0.151 & 0.226 & 2.2 & 0.069 & 0.063 & 0.094 \\
\hline 0.4166 & 0.17 & 0.151 & 0.22 & 2.4 & 0.069 & 0.056 & 0.088 \\
\hline 0.4333 & 0.163 & 0.144 & 0.214 & 2.6 & 0.063 & 0.056 & 0.088 \\
\hline 0.45 & 0.157 & 0.138 & 0.207 & 2.8 & 0.063 & 0.056 & 0.081 \\
\hline 0.4666 & 0.157 & 0.138 & 0.201 & 3 & 0.063 & 0.056 & 0.081 \\
\hline 0.4833 & 0.151 & 0.138 & 0.201 & 3.2 & 0.056 & 0.05 & 0.081 \\
\hline 0.5 & 0.151 & 0.132 & 0.195 & 3.4 & 0.056 & 0.05 & 0.075 \\
\hline 0.5166 & 0.151 & 0.132 & 0.188 & 3.6 & 0.056 & 0.05 & 0.075 \\
\hline 0.5333 & 0.144 & 0.125 & 0.188 & 3.8 & 0.056 & 0.05 & 0.069 \\
\hline 0.55 & 0.144 & 0.125 & 0.182 & 4 & 0.05 & 0.044 & 0.069 \\
\hline 0.5666 & 0.144 & 0.125 & 0.182 & 4.2 & 0.05 & 0.044 & 0.069 \\
\hline 0.5833 & 0.138 & 0.119 & 0.176 & 4.4 & 0.05 & 0.044 & 0.069 \\
\hline 0.6 & 0.138 & 0.119 & 0.176 & 4.6 & 0.05 & 0.044 & 0.063 \\
\hline 0.6166 & 0.132 & 0.119 & 0.176 & 4.8 & 0.044 & 0.044 & 0.063 \\
\hline 0.6333 & 0.132 & 0.119 & 0.17 & 5 & 0.044 & 0.044 & 0.063 \\
\hline 0.65 & 0.132 & 0.113 & 0.17 & 5.2 & 0.044 & 0.044 & 0.063 \\
\hline 0.6666 & 0.125 & 0.113 & 0.163 & 5.4 & 0.044 & 0.044 & 0.063 \\
\hline 0.6833 & 0.125 & 0.113 & 0.163 & 5.6 & 0.044 & 0.044 & 0.063 \\
\hline
\end{tabular}


TABLE A.11 (Cont.)

\begin{tabular}{|c|c|c|c|c|c|c|c|}
\hline \multirow[b]{2}{*}{$\begin{array}{c}\text { Elapsed } \\
\text { Time } \\
\text { (min) }\end{array}$} & \multicolumn{3}{|c|}{ Residual Drawdown (ft) } & \multirow[b]{2}{*}{$\begin{array}{c}\text { Elapsed } \\
\text { Time } \\
\text { (min) }\end{array}$} & \multicolumn{3}{|c|}{ Residual Drawdown (ft) } \\
\hline & $\begin{array}{l}\text { Test } 5 \\
\text { Step } 0\end{array}$ & $\begin{array}{l}\text { Test } 5 \\
\text { Step } 1\end{array}$ & $\begin{array}{l}\text { Test } 5 \\
\text { Step } 2\end{array}$ & & $\begin{array}{l}\text { Test } 5 \\
\text { Step } 0\end{array}$ & $\begin{array}{l}\text { Test } 5 \\
\text { Step } 1\end{array}$ & $\begin{array}{l}\text { Test } 5 \\
\text { Step } 2\end{array}$ \\
\hline 5.8 & 0.044 & 0.044 & 0.056 & 8 & 0.037 & 0.037 & 0.05 \\
\hline 6 & 0.044 & 0.044 & 0.056 & 8.2 & 0.037 & 0.037 & 0.05 \\
\hline 6.2 & 0.044 & 0.037 & 0.056 & 8.4 & 0.037 & 0.031 & 0.05 \\
\hline 6.4 & 0.044 & 0.037 & 0.056 & 8.6 & 0.037 & 0.037 & 0.05 \\
\hline 6.6 & 0.037 & 0.037 & 0.056 & 8.8 & 0.037 & 0.031 & 0.05 \\
\hline 6.8 & 0.037 & 0.037 & 0.056 & 9 & 0.037 & 0.031 & 0.05 \\
\hline 7 & 0.037 & 0.037 & 0.056 & 9.2 & 0.037 & 0.037 & 0.05 \\
\hline 7.2 & 0.037 & 0.037 & 0.056 & 9.4 & 0.031 & 0.031 & 0.05 \\
\hline 7.4 & 0.037 & 0.037 & 0.05 & 9.6 & 0.031 & 0.031 & 0.044 \\
\hline 7.6 & 0.037 & 0.037 & 0.05 & 9.8 & 0.031 & 0.037 & 0.05 \\
\hline 7.8 & 0.037 & 0.037 & 0.05 & 10 & 0.031 & 0.031 & 0.044 \\
\hline
\end{tabular}


TABLE A.12 Slug test data for boring SB07R (effective saturated thickness $=15 \mathrm{ft}$ : length of well $=15 \mathrm{ft}$; length of screen $=15 \mathrm{ft}$; casing radius $=0.08333 \mathrm{ft}$; borehole radius $=0.3438 \mathrm{ft} ; \mathrm{Kz} / \mathrm{Kr}=1$ ).

\begin{tabular}{|c|c|c|c|c|c|}
\hline \multirow[b]{2}{*}{$\begin{array}{c}\text { Elapsed } \\
\text { Time } \\
\text { (min) }\end{array}$} & \multicolumn{2}{|c|}{$\begin{array}{c}\text { Residual } \\
\text { Drawdown (ft) }\end{array}$} & \multirow[b]{2}{*}{$\begin{array}{c}\text { Elapsed } \\
\text { Time } \\
\text { (min) }\end{array}$} & \multicolumn{2}{|c|}{$\begin{array}{c}\text { Residual } \\
\text { Drawdown (ft) }\end{array}$} \\
\hline & $\begin{array}{l}\text { Test } 4 \\
\text { Step } 0\end{array}$ & $\begin{array}{l}\text { Test } 4 \\
\text { Step } 1\end{array}$ & & $\begin{array}{l}\text { Test } 4 \\
\text { Step } 0\end{array}$ & $\begin{array}{l}\text { Test } 4 \\
\text { Step } 1\end{array}$ \\
\hline 0 & 4.255 & 4.097 & 0.13 & 3.298 & 2.927 \\
\hline 0.0033 & 5.545 & 4.903 & 0.1333 & 3.292 & 2.92 \\
\hline 0.0066 & 4.324 & 3.638 & 0.1366 & 3.292 & 2.92 \\
\hline 0.01 & 3.021 & 2.631 & 0.14 & 3.285 & 2.914 \\
\hline 0.0133 & 3.109 & 2.839 & 0.1433 & 3.285 & 2.914 \\
\hline 0.0166 & 3.739 & 3.361 & 0.1466 & 3.279 & 2.908 \\
\hline 0.02 & 3.896 & 3.437 & 0.15 & 3.279 & 2.908 \\
\hline 0.0233 & 3.625 & 3.191 & 0.1533 & 3.273 & 2.901 \\
\hline 0.0266 & 3.411 & 3.027 & 0.1566 & 3.273 & 2.901 \\
\hline 0.03 & 3.43 & 3.053 & 0.16 & 3.267 & 2.901 \\
\hline 0.0333 & 3.512 & 3.122 & 0.1633 & 3.26 & 2.895 \\
\hline 0.0366 & 3.518 & 3.122 & 0.1666 & 3.26 & 2.895 \\
\hline 0.04 & 3.462 & 3.078 & 0.17 & 3.26 & 2.889 \\
\hline 0.0433 & 3.424 & 3.04 & 0.1733 & 3.254 & 2.889 \\
\hline 0.0466 & 3.418 & 3.04 & 0.1766 & 3.254 & 2.883 \\
\hline 0.05 & 3.424 & 3.04 & 0.18 & 3.248 & 2.883 \\
\hline 0.0533 & 3.418 & 3.034 & 0.1833 & 3.248 & 2.883 \\
\hline 0.0566 & 3.405 & 3.021 & 0.1866 & 3.248 & 2.883 \\
\hline 0.06 & 3.392 & 3.015 & 0.19 & 3.241 & 2.883 \\
\hline 0.0633 & 3.386 & 3.008 & 0.1933 & 3.235 & 2.876 \\
\hline 0.0666 & 3.38 & 3.002 & 0.1966 & 3.235 & 2.876 \\
\hline 0.07 & 3.374 & 2.996 & 0.2 & 3.235 & 2.87 \\
\hline 0.0733 & 3.367 & 2.99 & 0.2033 & 3.229 & 2.87 \\
\hline 0.0766 & 3.361 & 2.983 & 0.2066 & 3.229 & 2.87 \\
\hline 0.08 & 3.355 & 2.977 & 0.21 & 3.229 & 2.864 \\
\hline 0.0833 & 3.355 & 2.977 & 0.2133 & 3.222 & 2.864 \\
\hline 0.0866 & 3.348 & 2.971 & 0.2166 & 3.222 & 2.864 \\
\hline 0.09 & 3.342 & 2.964 & 0.22 & 3.216 & 2.857 \\
\hline 0.0933 & 3.336 & 2.964 & 0.2233 & 3.216 & 2.857 \\
\hline 0.0966 & 3.329 & 2.958 & 0.2266 & 3.216 & 2.857 \\
\hline 0.1 & 3.329 & 2.952 & 0.23 & 3.21 & 2.851 \\
\hline 0.1033 & 3.323 & 2.952 & 0.2333 & 3.21 & 2.851 \\
\hline 0.1066 & 3.317 & 2.946 & 0.2366 & 3.204 & 2.851 \\
\hline 0.11 & 3.317 & 2.946 & 0.24 & 3.204 & 2.845 \\
\hline 0.1133 & 3.311 & 2.939 & 0.2433 & 3.204 & 2.845 \\
\hline 0.1166 & 3.311 & 2.939 & 0.2466 & 3.204 & 2.845 \\
\hline 0.12 & 3.304 & 2.933 & 0.25 & 3.197 & 2.839 \\
\hline 0.1233 & 3.304 & 2.927 & 0.2533 & 3.197 & 2.839 \\
\hline 0.1266 & 3.298 & 2.927 & 0.2566 & 3.197 & 2.839 \\
\hline
\end{tabular}


TABLE A.12 (Cont.)

\begin{tabular}{|c|c|c|c|c|c|}
\hline \multirow{2}{*}{$\begin{array}{c}\text { Elapsed } \\
\text { Time } \\
\text { (min) }\end{array}$} & \multicolumn{2}{|c|}{$\begin{array}{c}\text { Residual } \\
\text { Drawdown (ft) }\end{array}$} & \multirow{2}{*}{$\begin{array}{c}\text { Elapsed } \\
\text { Time } \\
\text { (min) }\end{array}$} & \multicolumn{2}{|c|}{$\begin{array}{c}\text { Residual } \\
\text { Drawdown (ft) }\end{array}$} \\
\hline & $\begin{array}{l}\text { Test } 4 \\
\text { Step } 0\end{array}$ & $\begin{array}{l}\text { Test } 4 \\
\text { Step } 1\end{array}$ & & $\begin{array}{l}\text { Test } 4 \\
\text { Step } 0\end{array}$ & $\begin{array}{l}\text { Test } 4 \\
\text { Step } 1\end{array}$ \\
\hline 0.26 & 3.191 & 2.832 & 0.65 & 3.002 & 2.669 \\
\hline 0.2633 & 3.191 & 2.832 & 0.6666 & 2.996 & 2.662 \\
\hline 0.2666 & 3.191 & 2.832 & 0.6833 & 2.99 & 2.656 \\
\hline 0.27 & 3.185 & 2.832 & 0.7 & 2.983 & 2.65 \\
\hline 0.2733 & 3.185 & 2.826 & 0.7166 & 2.977 & 2.643 \\
\hline 0.2766 & 3.185 & 2.826 & 0.7333 & 2.971 & 2.637 \\
\hline 0.28 & 3.178 & 2.826 & 0.75 & 2.964 & 2.637 \\
\hline 0.2833 & 3.178 & 2.826 & 0.7666 & 2.958 & 2.631 \\
\hline 0.2866 & 3.178 & 2.82 & 0.7833 & 2.952 & 2.625 \\
\hline 0.29 & 3.172 & 2.82 & 0.8 & 2.946 & 2.618 \\
\hline 0.2933 & 3.172 & 2.82 & 0.8166 & 2.946 & 2.618 \\
\hline 0.2966 & 3.172 & 2.82 & 0.8333 & 2.939 & 2.612 \\
\hline 0.3 & 3.166 & 2.813 & 0.85 & 2.933 & 2.606 \\
\hline 0.3033 & 3.166 & 2.813 & 0.8666 & 2.927 & 2.599 \\
\hline 0.3066 & 3.166 & 2.813 & 0.8833 & 2.92 & 2.593 \\
\hline 0.31 & 3.166 & 2.807 & 0.9 & 2.914 & 2.587 \\
\hline 0.3133 & 3.16 & 2.807 & 0.9166 & 2.908 & 2.587 \\
\hline 0.3166 & 3.16 & 2.807 & 0.9333 & 2.901 & 2.58 \\
\hline 0.32 & 3.16 & 2.807 & 0.95 & 2.895 & 2.574 \\
\hline 0.3233 & 3.153 & 2.801 & 0.9666 & 2.889 & 2.568 \\
\hline 0.3266 & 3.153 & 2.801 & 0.9833 & 2.889 & 2.568 \\
\hline 0.33 & 3.153 & 2.801 & 1 & 2.883 & 2.562 \\
\hline 0.3333 & 3.153 & 2.794 & 1.2 & 2.82 & 2.505 \\
\hline 0.35 & 3.141 & 2.788 & 1.4 & 2.769 & 2.455 \\
\hline 0.3666 & 3.134 & 2.782 & 1.6 & 2.713 & 2.417 \\
\hline 0.3833 & 3.122 & 2.776 & 1.8 & 2.669 & 2.366 \\
\hline 0.4 & 3.115 & 2.763 & 2 & 2.625 & 2.329 \\
\hline 0.4166 & 3.109 & 2.757 & 2.2 & 2.58 & 2.297 \\
\hline 0.4333 & 3.097 & 2.75 & 2.4 & 2.536 & 2.253 \\
\hline 0.45 & 3.09 & 2.744 & 2.6 & 2.499 & 2.222 \\
\hline 0.4666 & 3.084 & 2.738 & 2.8 & 2.461 & 2.184 \\
\hline 0.4833 & 3.071 & 2.732 & 3 & 2.423 & 2.152 \\
\hline 0.5 & 3.065 & 2.725 & 3.2 & 2.385 & 2.121 \\
\hline 0.5166 & 3.059 & 2.719 & 3.4 & 2.354 & 2.09 \\
\hline 0.5333 & 3.053 & 2.713 & 3.6 & 2.316 & 2.058 \\
\hline 0.55 & 3.046 & 2.7 & 3.8 & 2.285 & 2.026 \\
\hline 0.5666 & 3.04 & 2.694 & 4 & 2.253 & 1.995 \\
\hline 0.5833 & 3.034 & 2.694 & 4.2 & 2.215 & 1.97 \\
\hline 0.6 & 3.021 & 2.687 & 4.4 & 2.184 & 1.938 \\
\hline 0.6166 & 3.015 & 2.681 & 4.6 & 2.159 & 1.913 \\
\hline 0.6333 & 3.008 & 2.675 & 4.8 & 2.127 & 1.888 \\
\hline
\end{tabular}


TABLE A.12 (Cont.)

\begin{tabular}{|c|c|c|c|c|c|}
\hline \multirow[b]{2}{*}{$\begin{array}{c}\text { Elapsed } \\
\text { Time } \\
\text { (min) }\end{array}$} & \multicolumn{2}{|c|}{$\begin{array}{c}\text { Residual } \\
\text { Drawdown (ft) }\end{array}$} & \multirow[b]{2}{*}{$\begin{array}{c}\text { Elapsed } \\
\text { Time } \\
\text { (min) }\end{array}$} & \multicolumn{2}{|c|}{$\begin{array}{c}\text { Residual } \\
\text { Drawdown (ft) }\end{array}$} \\
\hline & $\begin{array}{l}\text { Test } 4 \\
\text { Step } 0\end{array}$ & $\begin{array}{l}\text { Test } 4 \\
\text { Step } 1\end{array}$ & & $\begin{array}{l}\text { Test } 4 \\
\text { Step } 0\end{array}$ & $\begin{array}{l}\text { Test } 4 \\
\text { Step } 1\end{array}$ \\
\hline 5 & 2.096 & 1.863 & 9.8 & 1.517 & 1.34 \\
\hline 5.2 & 2.064 & 1.832 & 10 & 1.498 & 1.328 \\
\hline 5.4 & 2.033 & 1.813 & 12 & 1.315 & 1.158 \\
\hline 5.6 & 2.008 & 1.781 & 14 & 1.158 & 1.026 \\
\hline 5.8 & 1.982 & 1.756 & 16 & 1.019 & 0.893 \\
\hline 6 & 1.951 & 1.731 & 18 & 0.9 & 0.793 \\
\hline 6.2 & 1.932 & 1.712 & 20 & 0.799 & 0.698 \\
\hline 6.4 & 1.901 & 1.687 & 22 & 0.705 & 0.617 \\
\hline 6.6 & 1.876 & 1.662 & 24 & 0.629 & 0.547 \\
\hline 6.8 & 1.85 & 1.643 & 26 & 0.554 & 0.484 \\
\hline 7 & 1.825 & 1.617 & 28 & 0.497 & 0.428 \\
\hline 7.2 & 1.8 & 1.599 & 30 & 0.44 & 0.377 \\
\hline 7.4 & 1.775 & 1.573 & 32 & 0.39 & 0.34 \\
\hline 7.6 & 1.75 & 1.554 & 34 & 0.352 & 0.295 \\
\hline 7.8 & 1.731 & 1.536 & 36 & 0.308 & 0.264 \\
\hline 8 & 1.706 & 1.51 & 38 & 0.277 & 0.233 \\
\hline 8.2 & 1.68 & 1.492 & 40 & 0.245 & 0.207 \\
\hline 8.4 & 1.662 & 1.473 & 42 & 0.22 & 0.182 \\
\hline 8.6 & 1.636 & 1.454 & 44 & 0.195 & 0.163 \\
\hline 8.8 & 1.617 & 1.435 & 46 & 0.176 & 0.144 \\
\hline 9 & 1.599 & 1.416 & 48 & 0.157 & 0.126 \\
\hline 9.2 & 1.573 & 1.397 & 50 & 0.138 & 0.107 \\
\hline 9.4 & 1.554 & 1.378 & 52 & 0.126 & \\
\hline 9.6 & 1.536 & 1.366 & 54 & 0.113 & \\
\hline
\end{tabular}


TABLE A.13 Slug test data for boring SB08 (effective saturated thickness $=10 \mathrm{ft}$ : length of well $=10 \mathrm{ft}$; length of screen $=10 \mathrm{ft}$; casing radius $=0.04167 \mathrm{ft}$; borehole radius $=0.05469 \mathrm{ft} ; \mathrm{Kz} / \mathrm{Kr}=1)$.

\begin{tabular}{|c|c|c|c|c|c|c|c|}
\hline \multirow{2}{*}{$\begin{array}{c}\text { Elapsed } \\
\text { Time } \\
\text { (min) }\end{array}$} & \multicolumn{3}{|c|}{ Residual Drawdown (ft) } & \multirow{2}{*}{$\begin{array}{c}\text { Elapsed } \\
\text { Time } \\
\text { (min) }\end{array}$} & \multicolumn{3}{|c|}{ Residual Drawdown (ft) } \\
\hline & $\begin{array}{l}\text { Test } 3 \\
\text { Step } 0\end{array}$ & $\begin{array}{l}\text { Test } 3 \\
\text { Step } 1\end{array}$ & $\begin{array}{l}\text { Test } 3 \\
\text { Step } 2\end{array}$ & & $\begin{array}{l}\text { Test } 3 \\
\text { Step } 0\end{array}$ & $\begin{array}{l}\text { Test } 3 \\
\text { Step } 1\end{array}$ & $\begin{array}{l}\text { Test } 3 \\
\text { Step } 2\end{array}$ \\
\hline 0 & 3.965 & 3.77 & 2.757 & 0.1333 & 0.132 & 0.126 & 0.094 \\
\hline 0.0033 & 4.481 & 4.173 & 3.09 & 0.1366 & 0.132 & 0.126 & 0.088 \\
\hline 0.0066 & 4.746 & 4.292 & 3.204 & 0.14 & 0.126 & 0.113 & 0.088 \\
\hline 0.01 & 4.639 & 4.192 & 3.16 & 0.1433 & 0.12 & 0.113 & 0.082 \\
\hline 0.0133 & 4.267 & 3.902 & 3.015 & 0.1466 & 0.113 & 0.107 & 0.082 \\
\hline 0.0166 & 3.846 & 3.537 & 2.788 & 0.15 & 0.113 & 0.101 & 0.075 \\
\hline 0.02 & 3.449 & 3.178 & 2.524 & 0.1533 & 0.107 & 0.101 & 0.075 \\
\hline 0.0233 & 3.097 & 2.851 & 2.253 & 0.1566 & 0.101 & 0.094 & 0.069 \\
\hline 0.0266 & 2.776 & 2.555 & 2.008 & 0.16 & 0.101 & 0.094 & 0.069 \\
\hline 0.03 & 2.486 & 2.297 & 1.775 & 0.1633 & 0.101 & 0.088 & 0.069 \\
\hline 0.0333 & 2.222 & 2.058 & 1.58 & 0.1666 & 0.094 & 0.088 & 0.063 \\
\hline 0.0366 & 1.989 & 1.844 & 1.403 & 0.17 & 0.094 & 0.088 & 0.063 \\
\hline 0.04 & 1.781 & 1.649 & 1.246 & 0.1733 & 0.088 & 0.082 & 0.063 \\
\hline 0.0433 & 1.586 & 1.479 & 1.107 & 0.1766 & 0.088 & 0.082 & 0.057 \\
\hline 0.0466 & 1.422 & 1.322 & 0.982 & 0.18 & 0.088 & 0.082 & 0.057 \\
\hline 0.05 & 1.271 & 1.183 & 0.868 & 0.1833 & 0.082 & 0.075 & 0.057 \\
\hline 0.0533 & 1.133 & 1.051 & 0.774 & 0.1866 & 0.082 & 0.075 & 0.057 \\
\hline 0.0566 & 1.013 & 0.944 & 0.686 & 0.19 & 0.082 & 0.075 & 0.05 \\
\hline 0.06 & 0.9 & 0.843 & 0.604 & 0.1933 & 0.075 & 0.069 & 0.05 \\
\hline 0.0633 & 0.806 & 0.755 & 0.541 & 0.1966 & 0.075 & 0.069 & 0.05 \\
\hline 0.0666 & 0.717 & 0.673 & 0.478 & 0.2 & 0.069 & 0.069 & 0.05 \\
\hline 0.07 & 0.642 & 0.604 & 0.428 & 0.2033 & 0.069 & 0.069 & 0.044 \\
\hline 0.0733 & 0.573 & 0.541 & 0.377 & 0.2066 & 0.069 & 0.063 & 0.044 \\
\hline 0.0766 & 0.51 & 0.485 & 0.34 & 0.21 & 0.069 & 0.063 & 0.044 \\
\hline 0.08 & 0.459 & 0.434 & 0.29 & 0.2133 & 0.063 & 0.063 & 0.044 \\
\hline 0.0833 & 0.409 & 0.396 & 0.277 & 0.2166 & 0.063 & 0.063 & 0.044 \\
\hline 0.0866 & 0.371 & 0.352 & 0.245 & 0.22 & 0.063 & 0.057 & 0.044 \\
\hline 0.09 & 0.333 & 0.321 & 0.226 & 0.2233 & 0.063 & 0.057 & 0.038 \\
\hline 0.0933 & 0.302 & 0.29 & 0.201 & 0.2266 & 0.057 & 0.057 & 0.038 \\
\hline 0.0966 & 0.277 & 0.264 & 0.189 & 0.23 & 0.057 & 0.057 & 0.038 \\
\hline 0.1 & 0.252 & 0.245 & 0.17 & 0.2333 & 0.057 & 0.05 & 0.038 \\
\hline 0.1033 & 0.233 & 0.226 & 0.157 & 0.2366 & 0.057 & 0.05 & 0.038 \\
\hline 0.1066 & 0.214 & 0.207 & 0.144 & 0.24 & 0.057 & 0.05 & 0.038 \\
\hline 0.11 & 0.201 & 0.195 & 0.138 & 0.2433 & 0.05 & 0.05 & 0.031 \\
\hline 0.1133 & 0.189 & 0.182 & 0.126 & 0.2466 & 0.05 & 0.05 & 0.031 \\
\hline 0.1166 & 0.176 & 0.17 & 0.12 & 0.25 & 0.05 & 0.044 & 0.031 \\
\hline 0.12 & 0.163 & 0.157 & 0.113 & 0.2533 & 0.05 & 0.044 & 0.031 \\
\hline 0.1233 & 0.157 & 0.151 & 0.107 & 0.2566 & 0.05 & 0.044 & 0.031 \\
\hline 0.1266 & 0.144 & 0.144 & 0.101 & 0.26 & 0.05 & 0.044 & 0.031 \\
\hline 0.13 & 0.138 & 0.138 & 0.094 & 0.2633 & 0.044 & 0.044 & 0.031 \\
\hline
\end{tabular}


TABLE A.13 (Cont.)

\begin{tabular}{|c|c|c|c|c|c|c|c|}
\hline \multirow{2}{*}{$\begin{array}{c}\text { Elapsed } \\
\text { Time } \\
\text { (min) }\end{array}$} & \multicolumn{3}{|c|}{ Residual Drawdown (ft) } & \multirow{2}{*}{$\begin{array}{c}\text { Elapsed } \\
\text { Time } \\
\text { (min) }\end{array}$} & \multicolumn{3}{|c|}{ Residual Drawdown (ft) } \\
\hline & $\begin{array}{l}\text { Test } 3 \\
\text { Step } 0\end{array}$ & $\begin{array}{l}\text { Test } 3 \\
\text { Step } 1\end{array}$ & $\begin{array}{l}\text { Test } 3 \\
\text { Step } 2\end{array}$ & & $\begin{array}{l}\text { Test } 3 \\
\text { Step } 0\end{array}$ & $\begin{array}{l}\text { Test } 3 \\
\text { Step } 1\end{array}$ & $\begin{array}{l}\text { Test } 3 \\
\text { Step } 2\end{array}$ \\
\hline 0.2666 & 0.044 & 0.044 & 0.031 & 0.35 & 0.031 & 0.025 & 0.019 \\
\hline 0.27 & 0.044 & 0.044 & 0.031 & 0.3666 & 0.025 & 0.025 & 0.019 \\
\hline 0.2733 & 0.044 & 0.038 & 0.031 & 0.3833 & 0.025 & 0.025 & 0.019 \\
\hline 0.2766 & 0.044 & 0.038 & 0.025 & 0.4 & 0.025 & 0.025 & 0.012 \\
\hline 0.28 & 0.044 & 0.038 & 0.025 & 0.4166 & 0.019 & 0.019 & 0.012 \\
\hline 0.2833 & 0.044 & 0.038 & 0.025 & 0.4333 & 0.019 & 0.019 & 0.012 \\
\hline 0.2866 & 0.038 & 0.038 & 0.025 & 0.45 & 0.019 & 0.019 & 0.012 \\
\hline 0.29 & 0.038 & 0.038 & 0.025 & 0.4666 & 0.019 & 0.019 & 0.012 \\
\hline 0.2933 & 0.038 & 0.038 & 0.025 & 0.4833 & 0.019 & 0.012 & 0.006 \\
\hline 0.2966 & 0.038 & 0.038 & 0.025 & 0.5 & 0.012 & 0.012 & 0.006 \\
\hline 0.3 & 0.038 & 0.031 & 0.025 & 0.5166 & 0.012 & 0.012 & 0.006 \\
\hline 0.3033 & 0.038 & 0.031 & 0.025 & 0.5333 & 0.012 & 0.012 & 0.006 \\
\hline 0.3066 & 0.038 & 0.031 & 0.025 & 0.55 & 0.012 & 0.012 & 0.006 \\
\hline 0.31 & 0.038 & 0.031 & 0.025 & 0.5666 & 0.012 & 0.012 & 0.006 \\
\hline 0.3133 & 0.038 & 0.031 & 0.025 & 0.5833 & 0.012 & 0.012 & 0.006 \\
\hline 0.3166 & 0.038 & 0.031 & 0.019 & 0.6 & 0.012 & 0.012 & 0.006 \\
\hline 0.32 & 0.031 & 0.031 & 0.019 & 0.6166 & 0.006 & 0.006 & 0.006 \\
\hline 0.3233 & 0.038 & 0.031 & 0.019 & 0.6333 & 0.006 & 0.006 & 0.006 \\
\hline 0.3266 & 0.038 & 0.031 & 0.025 & 0.65 & 0.006 & 0.012 & 0.006 \\
\hline 0.33 & 0.031 & 0.031 & 0.019 & 0.6666 & 0.006 & 0.006 & 0.006 \\
\hline 0.3333 & 0.031 & 0.031 & 0.025 & & & & \\
\hline
\end{tabular}




\section{Appendix B:}

Studies on the Degradation of Carbon Tetrachloride in the Presence of Zero-Valent Iron (February 2007) 


\section{Appendix B:}

\section{Studies on the Degradation of Carbon Tetrachloride in the Presence of Zero-Valent Iron (February 2007)}

\section{B.1 Introduction}

Attempts at bioremediation of carbon tetrachloride contamination in groundwater have met with limited success, under either anaerobic (Dybas et al. 1998) or aerobic (Fogel et al. 1986; Henson et al. 1988) conditions. The difficulties seem to result from the toxicity of carbon tetrachloride to microorganisms, as well as the production of hazardous intermediates such as chloroform and methylene chloride. Recently, the possible use of nanoscale particles for in situ treatment of carbon tetrachloride contamination has been considered (Amonette 2006; Wang and Zhang 1997; Vogel et al. 1987). The theoretical potential benefits of nanoscale particles include their abilities to flow with groundwater and to promote rapid degradation of organic contaminants, in some cases immobilizing dissolved metals.

Nanoparticles of zero-valent iron (ZVI) have been considered for in situ remediation of carbon tetrachloride (Wang and Zhang 1997). Although the mechanisms at first glance might appear straightforward, more detailed observation reveals complex pathways and products resulting from reductive transformation of carbon tetrachloride. Depending on the type of iron present and the relative availability of electrons, hydrogen, nucleophiles, and even oxygen, products can range from toxic hexachloroethane, tetrachloroethene, trichloromethane, and dichloromethane to relatively innocuous carbon monoxide, carbon dioxide, and methane. In most circumstances, the dominant toxic product of reductive degradation of carbon tetrachloride is chloroform. Yields of chloroform in different iron-containing systems range from $20 \%$ to $80 \%$ (Amonette 2006).

Recent advances in applications of ZVI include products patented by Adventus Americas, Inc. (Freeport, Illinois). The Adventus product $\mathrm{EHC}^{\circledR}$ combines controlled release of carbon with ZVI for stimulation of in situ chemical reduction of carbon tetrachloride and other persistent organic compounds in groundwater. With this product, a number of physical, chemical, and microbiological processes combine to create very strong reducing conditions that stimulate rapid and complete dechlorination of organic solvents such as carbon tetrachloride. 
The organic component of EHC (guar gum) is nutrient rich and hydrophilic. On the ZVI particles with their high surface area, this carbon source supports the growth of bacteria in groundwater. As the bacteria grow, oxygen is consumed, and the oxidation-reduction potential (ORP) in the groundwater decreases to values approaching $-600 \mathrm{mV}$. At this potential, the small ZVI particles provide substantial reactive surface area and directly stimulate chemical dechlorination. In addition, indigenous heterotrophic bacteria that can ferment the carbon in the guar gum release a variety of volatile fatty acids that diffuse from the site of the fermentation into the groundwater plume and serve as electron donors supporting further bacterial reactions.

We report here the results of series of studies to evaluate the effectiveness - for the possible cleanup of contaminated sites in Nebraska and Kansas - of the Adventus ZVI products EHC and EHC-M (formulated for immobilization of metals, plus treatment of chlorinated solvents). A further goal is to understand the mechanisms of action of these products and the pathways they employ for the destruction of carbon tetrachloride.

In the work reported here, the effectiveness of the Adventus ZVI products EHC and EHC-M in reducing carbon tetrachloride was evaluated under laboratory conditions. Samples from a contaminated environmental area were collected to study their effect on the action of ZVI. Parameters monitored included $\mathrm{pH}$, reaction rates, ORP, and the formation of organic products.

\section{B.2 Experimental Setup}

\section{B.2.1 Instrumentation}

The equipment used was a gas chromatograph (HP-6890, Agilent Technologies, Wilmington, Delaware, USA) with a mass spectrometer (HP-5892, Agilent). Heated lines were used to interface the autosampler unit (HP-2016, Agilent) to the gas chromatograph.

\section{B.2.2 Batch Studies}

For these laboratory studies, containers were filled with water, ZVI (Adventus EHC or EHC-M) material, and an aliquot of carbon tetrachloride. Deionized water (NANOpure ${ }^{\circledR}$ DIamond $^{\mathrm{TM}}$, Barnstead International, Dubuque, Iowa, USA) was added, except as specified for 
particular experiments. A ratio of 100:1 for liquid volume to ZVI material volume was maintained throughout the experiments. When soil was present, the ratio of soil to ZVI material was 5:1. Samples were placed directly in the autosampler, and measurements were made from time zero to a maximum of $220 \mathrm{hr}$. One sample containing no ZVI was used as a reference standard in each experiment.

\section{B.2.3 Reagents}

A standard solution of carbon tetrachloride at $100 \mu \mathrm{g} / \mathrm{mL}$ in methanol (Chem Service, West Chester, Pennsylvania, USA) was used to prepare a solution with an initial analyte concentration of $100 \mathrm{ppb}$. These solutions meet or exceed all requirements and guidelines set forth in 40 Code of Federal Regulations Part 136. The stock solutions were stored at $4{ }^{\circ} \mathrm{C}$, and dilutions were prepared daily as needed. All standard solutions and dilutions were made by using Ultra Resi-Analyzed ${ }^{\mathrm{TM}}$ methanol (J.T. Baker, Phillipsburg, New Jersey, USA).

\section{B.2.4 Environmental Samples}

Soil samples from Centralia, Kansas, used in these experiments came from monitoring well MW02, at a depth of $51 \mathrm{ft}$ BGL. This is the location where the major contamination has been found in the aquifer at the Centralia site. Prior to its introduction into batch experimental mixtures, the dry core soil sample was homogenized by using a size 16 mesh (0.0394 in.). Water from Centralia was collected from a drinking water well in the area.

\section{B.3 Results and Discussion}

In experiments using only ZVI to decompose carbon tetrachloride to chloroform, no other product in the dechlorination path has ever been observed (Amonette 2006). Bioremediation is an alternate route for decomposition of carbon tetrachloride, but its mechanisms are complex, and the pathways are difficult to follow. For example, a study using bacteria in an iron-nitrate environment had some positive results in the laboratory, but the conditions were difficult to reproduce in the field. The application of ZVI would have a major advantage if the nanoparticles could set up an environment capable of completely reducing carbon tetrachloride to harmless products. 


\section{B.3.1 Ability of ZVI Material to Reduce Carbon Tetrachloride}

In our tests of degradation by ZVI, carbon tetrachloride was reduced at different rates, depending on the conditions of the experiment (Figures B.1-B.6, for example). The results provide evidence of dechlorination and formation of chloroform (typically accounting for $10-20 \%$ of the initial amount of carbon tetrachloride). The rest of the carbon tetrachloride went into a different pathway, with possible formation of relatively harmless products such as formic acid and carbon monoxide. When carbon tetrachloride disappeared almost completely from the solution, the small amount of chloroform remaining decomposed to form dichloromethane, as observed in Figure B.3.

\section{B.3.2 Effects of pH on the Reduction of Carbon Tetrachloride by ZVI}

Our initial experiment, performed with EHC-M, deionized water, and standard solutions under normal laboratory conditions, achieved less than $20 \%$ decomposition of the total carbon tetrachloride introduced, in more than $90 \mathrm{hr}$ of incubation (Figure B.1).

Iron characteristically remains in lower valance states at lower $\mathrm{pH}$ values. At neutral $\mathrm{pH}$ values, iron is easily oxidized to form iron oxide. To observe the effect of $\mathrm{pH}$ on the decomposition of carbon tetrachloride by ZVI, we added hydrochloric acid to decrease the $\mathrm{pH}$ of the solution. Figures B.2 and B.3 show the decomposition of carbon tetrachloride, with EHC and EHC-M respectively, in solutions at $\mathrm{pH}=1$. Both figures demonstrate rapid decomposition of carbon tetrachloride, within hours of mixing. In less than one day, almost $80 \%$ of the carbon tetrachloride introduced was decomposed, and minor production of chloroform was observed. Chloroform was produced not in a 1:1 ratio, as expected. After $90 \mathrm{hr}$, formation of a small amount (less than $1 \mathrm{ppb}$ ) of dichloromethane was observed.

To continue evaluation of the effect of $\mathrm{pH}$ on the degradation of carbon tetrachloride by ZVI, another experiment was performed with an acetic acid buffer at $\mathrm{pH}=3.1$. Results for EHC-M are shown in Figure B.4. Incubation for more than $140 \mathrm{hr}$ demonstrated a slower carbon tetrachloride decomposition rate than in experiments conducted at $\mathrm{pH}=1$ (Figures B.2 and B.3). Chloroform and dichloromethane were produced in small amounts (Figure B.4). 
The reaction half-lives at various $\mathrm{pH}$ levels are shown in Table B.1. The results indicate that the half-life of the reaction for decomposition of carbon tetrachloride increases with increasing $\mathrm{pH}$. Thus, $\mathrm{pH}$ plays an important role in degradation of carbon tetrachloride by ZVI.

\section{B.3.3 Decomposition of Carbon Tetrachloride by ZVI with Soil and Water from a Contaminated Site}

Soil samples for this study were selected from the core for monitoring well MW02 at Centralia, at the center of the contamination plume at $51 \mathrm{ft}$ BGL. In addition, water from the aquifer system at Centralia was used to mimic conditions in the field.

One reaction mixture for this study contained soil from the contaminated area at Centralia and ZVI material (EHC-M) in a 5:1 ratio, with sufficient deionized water $(\mathrm{pH}=5.2)$ to achieve a liquid to EHC-M ratio of approximately 100:1 (by volume). As Figure B.5 shows, the reaction started slowly, with only small changes in the concentration of carbon tetrachloride over time. Under these conditions, the half-life for carbon tetrachloride decomposition was $73 \mathrm{hr}$ (Table B.1).

A subsequent experiment combined EHC-M, carbon tetrachloride, and soil and water $(\mathrm{pH}=7.2)$ from the contaminated area. Figure B.6 shows the results. In this case, the reaction rate was even slower than with deionized water $(\mathrm{pH}=5.2$; Figure B.5), with a half-life of $145 \mathrm{hr}$ (Table B.1).

The behavior observed in Figures B.5 and B.6 is consistent with the behavior expected for ZVI coated with organic material. The results suggest that at the beginning, some of the free iron reacted to produce chloroform, but at longer times the decomposition was driven mainly by bacteria in the soil and water. The bacteria would use the organic material surrounding the ZVI nanoparticles as a food source, creating better conditions for the reaction of iron with carbon tetrachloride. The result was accelerated decomposition later in the incubation period, as shown in Figures B.5 and B.6. Almost $90 \%$ of the original carbon tetrachloride was decomposed in 140-160 hr in these two experiments.

Our hypothesis is that bacteria in the soil and water added to the reaction mixture used the organic material coating the iron nanoparticles to accomplish the following: 
- Decrease the oxygen levels

- Decrease the ORP, setting up a reducing environment

- Release a variety of volatile fatty acids that could be used as electron donors

- Decrease the $\mathrm{pH}$ of the solution

To understand the mechanism of degradation of carbon tetrachloride by EHC and EHC-M, we studied changes in the $\mathrm{pH}$ and ORP of the system (Figure B.6) containing ZVI, carbon tetrachloride, and soil and water from the contaminated site. Figure B.7 shows changes in $\mathrm{pH}$ with time. The overall change in $\mathrm{pH}$, from 7.2 to 6.8 , is not significant enough to explain the change in the reaction rate and the rapid decomposition of carbon tetrachloride observed in the presence of soil and water from the contaminated area (Figure B.6). Figure B.8 shows the change of ORP with time. In this case, the ORP seems to increase and decrease at random. Similar behavior has been reported by Adventus (E. Dimitrovic, unpublished data).

The results for $\mathrm{pH}$ and ORP suggest that decomposition of carbon tetrachloride by ZVI occurs through a complex mechanism. The bacteria appear to improve conditions for the reaction, but other changes at the molecular level might also be involved. More than $90 \%$ of the carbon tetrachloride was decomposed in our tests with soil from the contaminated area at Centralia (Figures B.5 and B.6).

\section{B.3.4 Effect of Sterilization of Soil and Water on Carbon Tetrachloride Decomposition by ZVI}

To determine whether active bacterial metabolism was supporting the decomposition of carbon tetrachloride by ZVI in the experiments illustrated in Figures B.5 and B.6, we added sterilized soil and water from the contaminated site to an experimental batch with carbon tetrachloride and EHC-M. If bacteria in the native soil and water samples dramatically affect the decomposition of carbon tetrachloride by ZVI, then sterilizing the soil and water should slow or even prevent decomposition.

Soil samples were sterilized by heating in an oven to $80^{\circ} \mathrm{C}$ on four consecutive days. Water samples were sterilized by boiling for $1 \mathrm{hr}$ at $100^{\circ} \mathrm{C}$. The EHC-M material is not sterile 
and was used without treatment. Heating EHC-M can cause decomposition of the material and oxidize the iron, therefore reducing the effectiveness of the product.

To the reaction mixture containing EHC-M, sterilized soil, and boiled water, an aliquot of carbon tetrachloride was added. Figure B.9 shows the results of analyses for volatile organic compounds over more than $220 \mathrm{hr}$ of monitoring. The plot is similar to the one obtained for a simultaneously conducted batch experiment with EHC-M and unsterilized soil and water (Figure B.10). Formation of gas was observed in both reaction systems.

These results do not rule out a role for bacteria in the decomposition of carbon tetrachloride by ZVI; however, the results do demonstrate that the decomposition is not dependent on the presence of live bacteria from the contaminated site. Clearly, ZVI (EHC-M) decomposed the carbon tetrachloride without the help of active bacteria from the contaminated site (Figure B.9). The results demonstrate significant complexity in the reaction system.

\section{B.3.5 Pathway for Carbon Tetrachloride Decomposition}

As stated in Section B.1, at first glance the mechanisms for degradation of carbon tetrachloride by ZVI appear straightforward, but more detailed observation reveals complex pathways and products. The degradation process is not well understood, and we are continuing to investigate the pathways.

One important factor is that the ZVI products tested can decompose carbon tetrachloride to compounds other than chloroform (the result typically observed in other studies). The products tested release (1) organic material to change the reaction conditions and (2) ZVI as a chemical reducing agent.

The ZVI products tested initiate a number of physical, chemical, and microbiological processes that combine to create very strong reducing conditions in situ and stimulate rapid and complete dechlorination of carbon tetrachloride. These processes include (1) biological reduction (consumption of oxygen and other electron acceptors); (2) chemical reduction of the oxidized pollutants, either directly by the reduced metals or indirectly via the formation of hydrogen that is used by bacteria as an electron donor; and (3) direct chemical oxidation due to ZVI oxidation- 
reduction reactions, via beta-elimination reactions and additional oxygen scavenging that decreases the ORP of the system.

Chemical routes for carbon tetrachloride degradation are usually kinetically controlled, and these types of process will play an important role in the decomposition. Carbon tetrachloride produces the trichloromethyl radical, which is transformed to yield chloroform under mild reducing conditions, or carbon monoxide and formic acid if the reducing conditions are stronger (due to a combination of effects). Possible mechanisms for chemical degradation in our ZVIcarbon tetrachloride systems are as follows:

Possible Mechanism 1:

$$
\begin{aligned}
& \mathrm{CCl}_{4}+\mathrm{e}^{-} \rightarrow \mathrm{Cl}_{3}-\mathrm{C} \cdot(\text { trichloromethyl radical })+\mathrm{Cl}^{-} \\
& \mathrm{Cl}_{3}-\mathrm{C} \cdot+\mathrm{H}^{+}+\mathrm{e}^{-} \rightarrow \mathrm{CHCl}_{3} \text { (chloroform) } \\
& \quad \mathrm{CHCl}_{3}+\mathrm{H}^{+}+2 \mathrm{e}^{-} \text {(strong reductant) } \rightarrow \mathrm{Cl}_{2} \mathrm{CH}_{2}+\mathrm{Cl}^{-}
\end{aligned}
$$

Possible Mechanism 2:

$$
\begin{aligned}
& \mathrm{CCl}_{4}+\mathrm{e}^{-} \rightarrow \mathrm{Cl}_{3}-\mathrm{C} \cdot(\text { trichloromethyl radical })+\mathrm{Cl}^{-}\left(\mathrm{e}^{-}\right) \\
& \mathrm{Cl}_{3}-\mathrm{C} \cdot+\mathrm{e}^{-} \rightarrow \mathrm{Cl}_{2}-\mathrm{C}:+\mathrm{Cl}^{-} \\
& \mathrm{Cl}_{2}-\mathrm{C}:+\mathrm{H}_{2} \mathrm{O} \rightarrow \mathrm{C} \equiv \mathrm{O} \text { (carbon monoxide) }+2 \mathrm{HCl} \\
& \mathrm{Cl}_{2}-\mathrm{C}:+2 \mathrm{H}_{2} \mathrm{O} \rightarrow \mathrm{HCOOH} \text { (formic acid) }+2 \mathrm{HCl}
\end{aligned}
$$

\section{B.3.6 Difference between EHC and EHC-M}

The main difference between the Adventus products EHC and EHC-M is that EHC-M contains a ligand that can trap metals that might otherwise become free in the environment. For example, arsenic, a natural element in soils, can become free during remediation processes and 
increase the concentration of arsenic in the groundwater. The ligand in EHC-M can capture the arsenic and avoid movement of the element into the water system.

The two Adventus products were equally effective in decomposing carbon tetrachloride in laboratory samples, as illustrated in Figures B.11 and B.12.

\section{B.3.7 Testing for Lead and Arsenic Contaminants in the Adventus Products}

A concern raised by the KDHE is the environmental effect of possible lead and arsenic contaminants in the EHC and EHC-M products. These materials and the guar gum used to coat the ZVI nanoparticles were analyzed in the laboratory for lead and arsenic. Results are presented in Table B.2.

According to the OSWER 9355.4-12 (1994 interim guidance) and the U.S. Environmental Protection Agency, lead concentrations are considered hazardous if they are above $400 \mathrm{mg} / \mathrm{kg}$ in bare soil in children's play areas or above $1,200 \mathrm{mg} / \mathrm{kg}$ in other places. Typical U.S. soil concentrations range from 10 to $30 \mathrm{mg} / \mathrm{kg}$. The lead values found in the ZVI materials $(10.3 \mathrm{mg} / \mathrm{kg}$ and $18.5 \mathrm{mg} / \mathrm{kg})$ are within the background levels. Arsenic was not found in the ZVI samples. The guar gum contained no detectable arsenic or lead.

\section{B.4 Conclusions}

Our studies on the use of the Adventus ZVI products EHC and EHC-M showed that the materials can reduce the concentrations of carbon tetrachloride in samples prepared in the laboratory. In use, these products combine a number of physical, chemical, and microbiological processes to create very strong reducing conditions that stimulate rapid and complete dechlorination of carbon tetrachloride.

Preliminary results for batch experiments using soil and water from the Centralia, Kansas, contaminated site showed that carbon tetrachloride can be decomposed by the ZVI products in the presence of the environmental materials. The reaction began slowly, but it accelerated as appropriate conditions were established by the combination of factors mentioned previously. Concentrations of carbon tetrachloride decreased by more than $90 \%$ in our laboratory studies. 
The ZVI technology offers the possibility of in situ remediation of carbon tetrachloride at contaminated sites. In the laboratory, the Adventus products showed promise, but conditions are not the same in the field. Subjecting the ZVI product to a field pilot study would demonstrate whether suitable conditions and decreased carbon tetrachloride concentrations can be achieved at a contaminated site. 
TABLE B.1 Carbon tetrachloride degradation half-life and $\mathrm{pH}$ in EHC batch tests.

\begin{tabular}{lccl}
\hline \multicolumn{1}{c}{ Figure } & $\mathrm{pH}$ & Half-life $(\mathrm{hr})$ & \multicolumn{1}{c}{ Description } \\
& & & \\
B.2, B.3 & 1.1 & 6 & Hydrochloric acid \\
B.4 & 3.1 & 12 & Acetic acid buffer \\
B.5 & 5.2 & 73 & Soila + deionized water \\
B.6, B.9, B.10, B.12 & 7.2 & $77-145$ & Soila + water from Centralia \\
& & & \\
\hline
\end{tabular}

a Soil from aquifer zone at Centralia (MW02, $51 \mathrm{ft} \mathrm{BGL).}$

TABLE B.2 Concentrations of lead and arsenic in Adventus products.

\begin{tabular}{lcc}
\hline Sample & As $(\mathrm{mg} / \mathrm{kg})$ & $\mathrm{Pb}(\mathrm{mg} / \mathrm{kg})$ \\
\hline Guar gum & $\mathrm{ND}^{\mathrm{a}}$ & $\mathrm{ND}^{\mathrm{b}}$ \\
EHC & $\mathrm{ND}^{\mathrm{a}}$ & 18.5 \\
EHC-M & $\mathrm{ND}^{\mathrm{a}}$ & 10.3 \\
& & \\
\hline
\end{tabular}

${ }^{\text {a }}$ Arsenic not detected at $0.32 \mathrm{mg} / \mathrm{kg}$.

${ }^{\mathrm{b}}$ Lead not detected at $0.21 \mathrm{mg} / \mathrm{kg}$. 


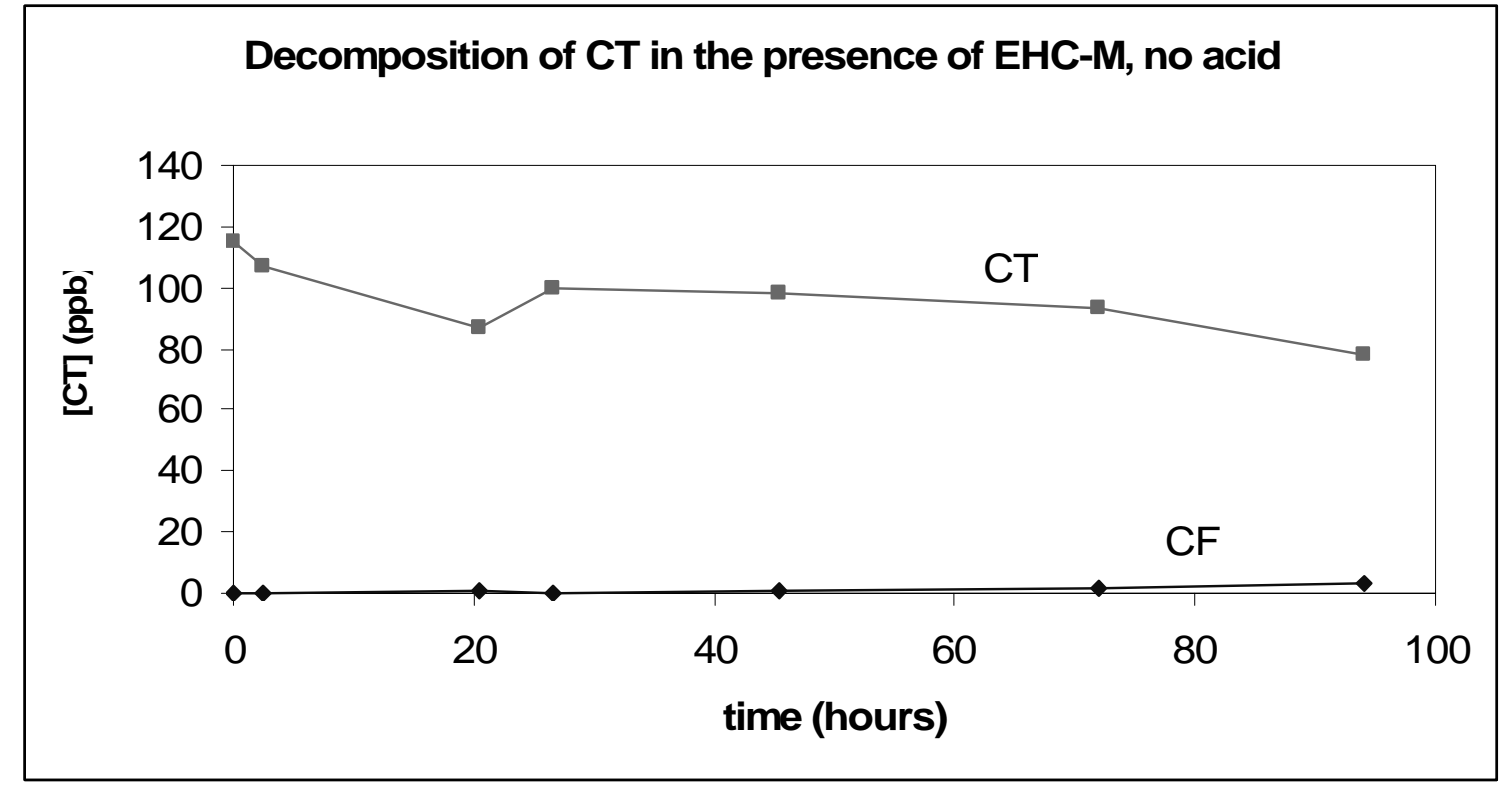

FIGURE B.1 Reaction components: Deionized water, EHC-M, carbon tetrachloride.

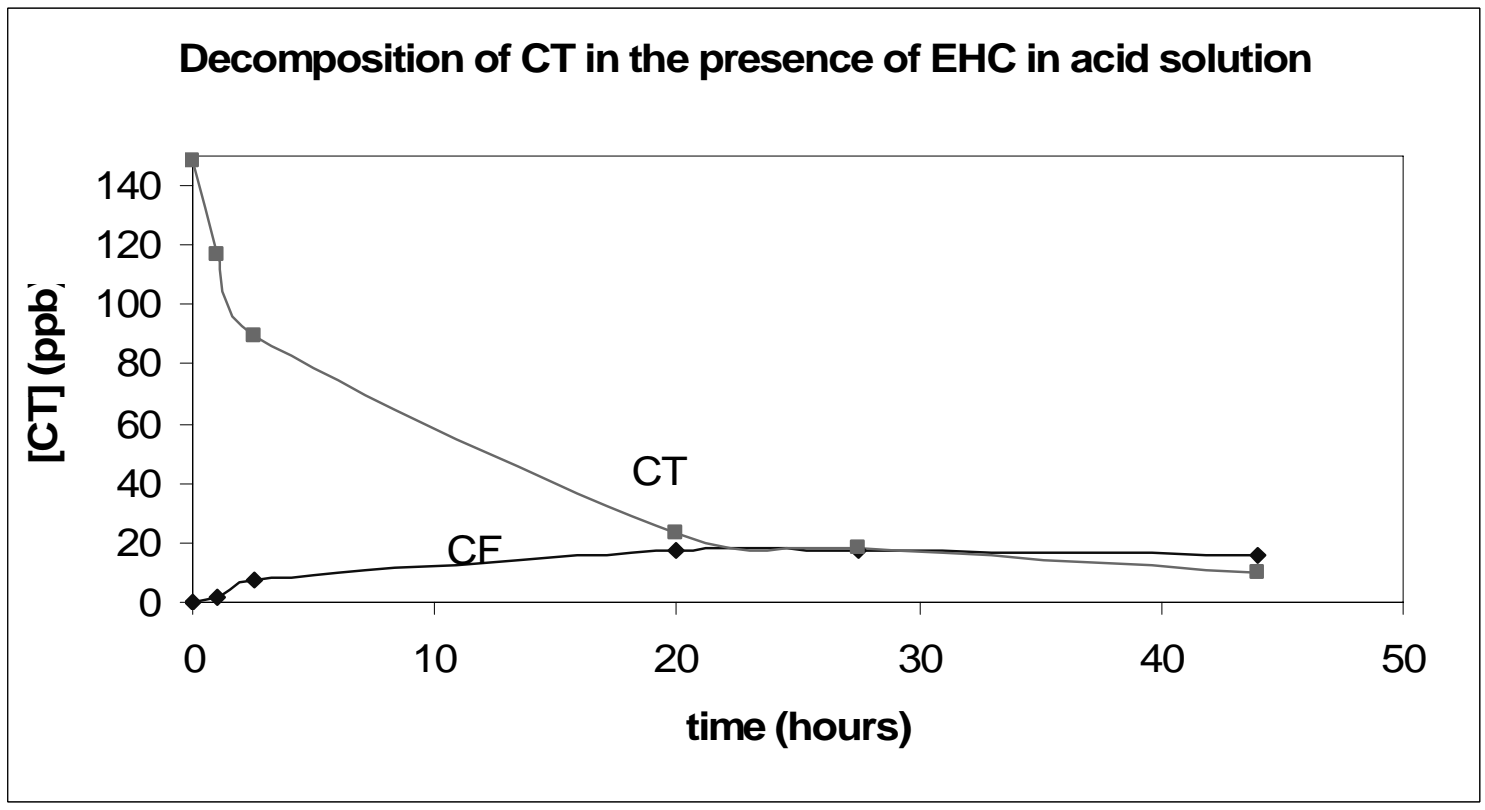

FIGURE B.2 Reaction components: Deionized water, EHC, carbon tetrachloride, hydrochloric acid $(\mathrm{pH}=1)$. 


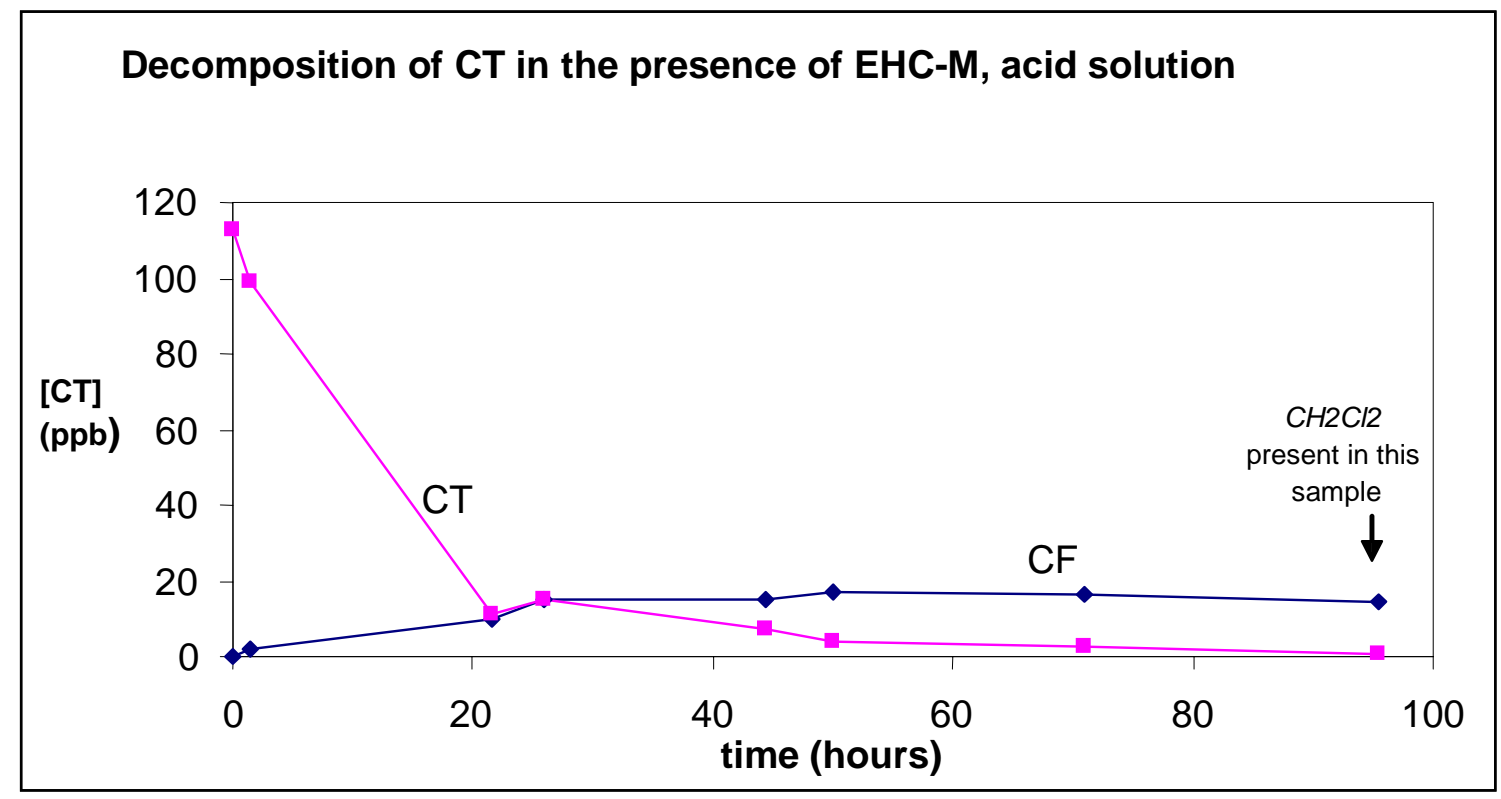

FIGURE B.3 Reaction components: Deionized water, EHC-M, carbon tetrachloride, hydrochloric acid $(\mathrm{pH}=1)$.

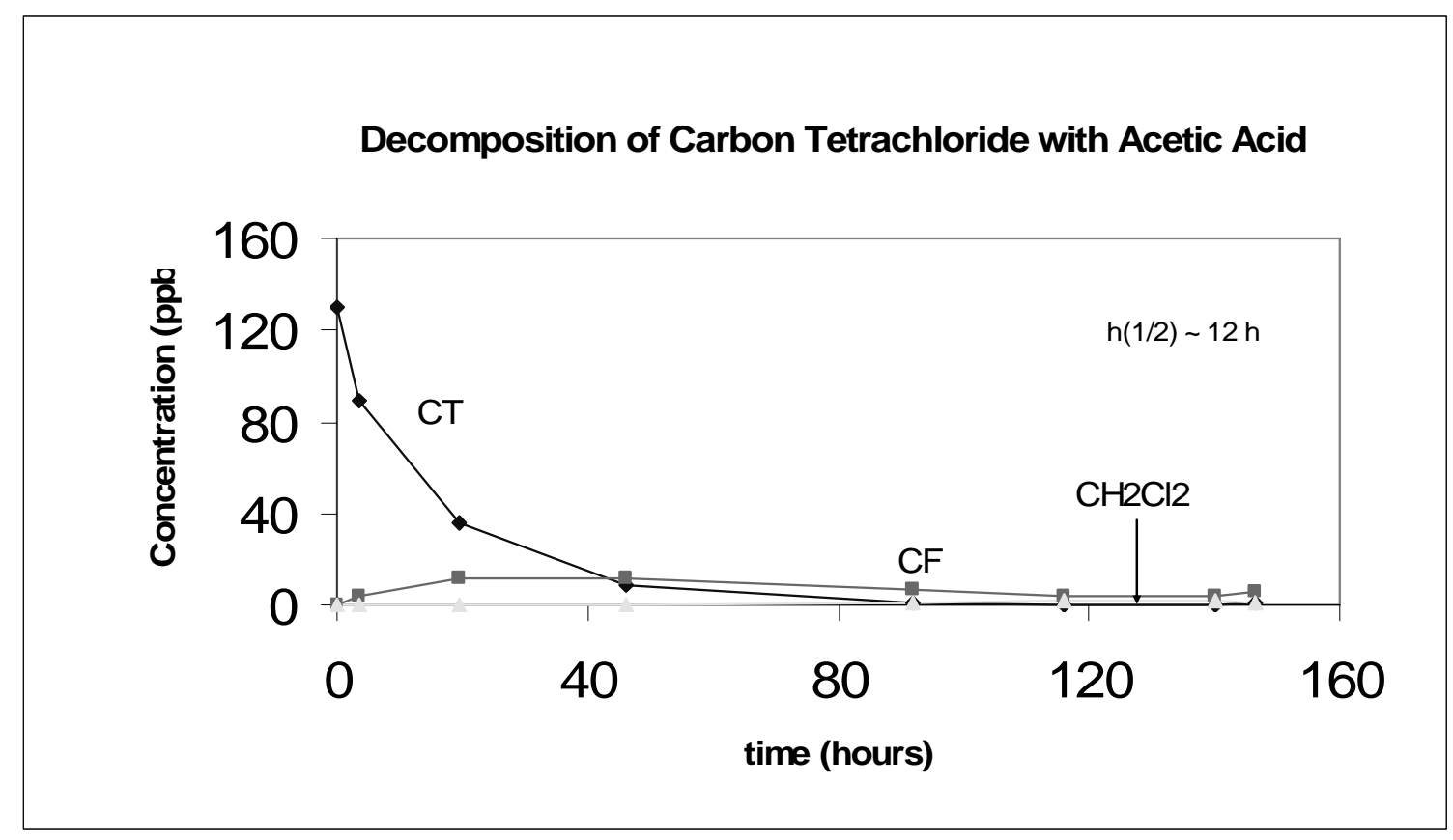

FIGURE B.4 Reaction components: Deionized water, EHC-M, carbon tetrachloride, acetic acid buffer $(\mathrm{pH}=3.1)$. 


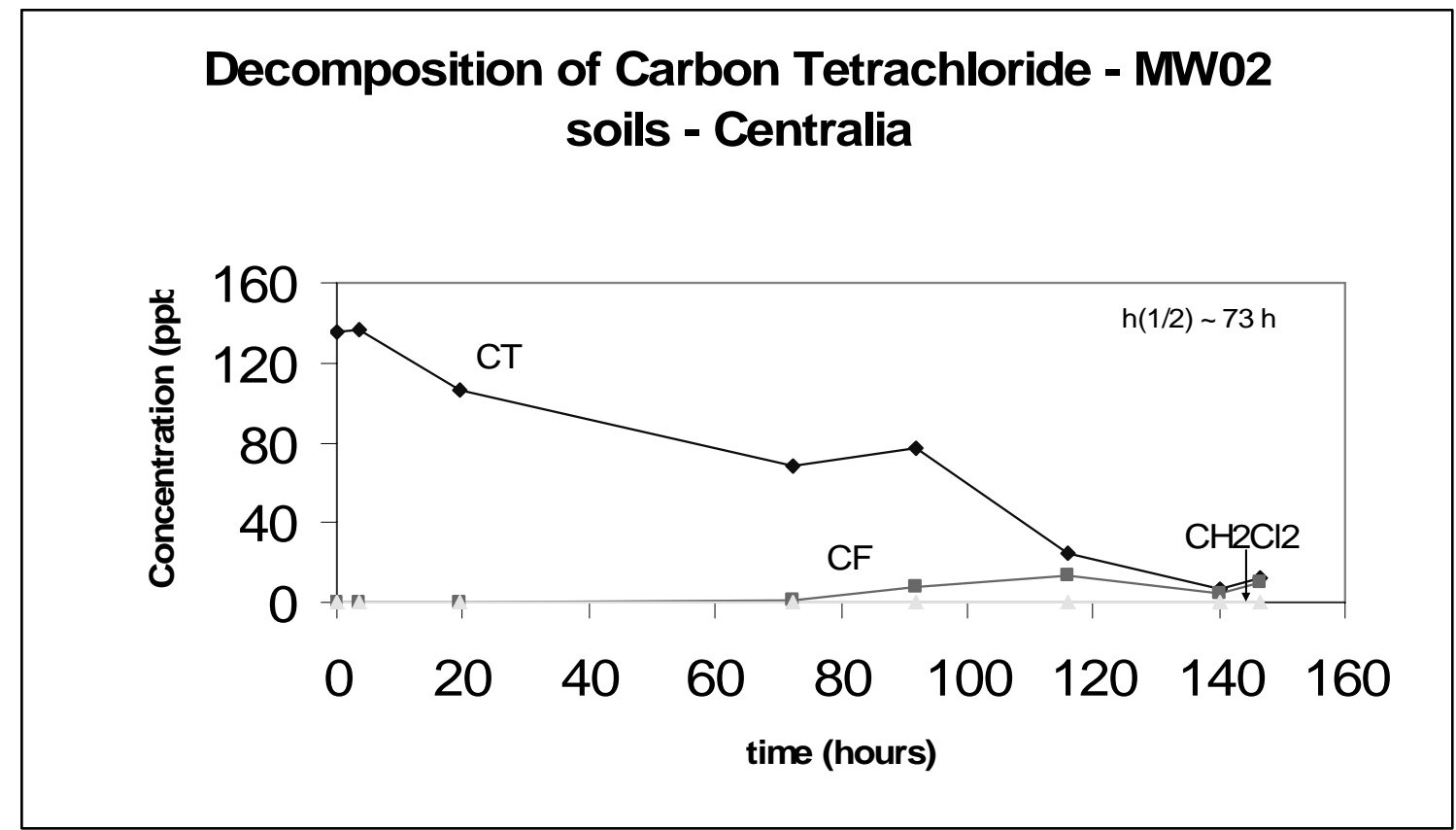

FIGURE B.5 Reaction components: Deionized water $(\mathrm{pH}=5.2)$, EHC-M, Centralia soil, carbon tetrachloride.

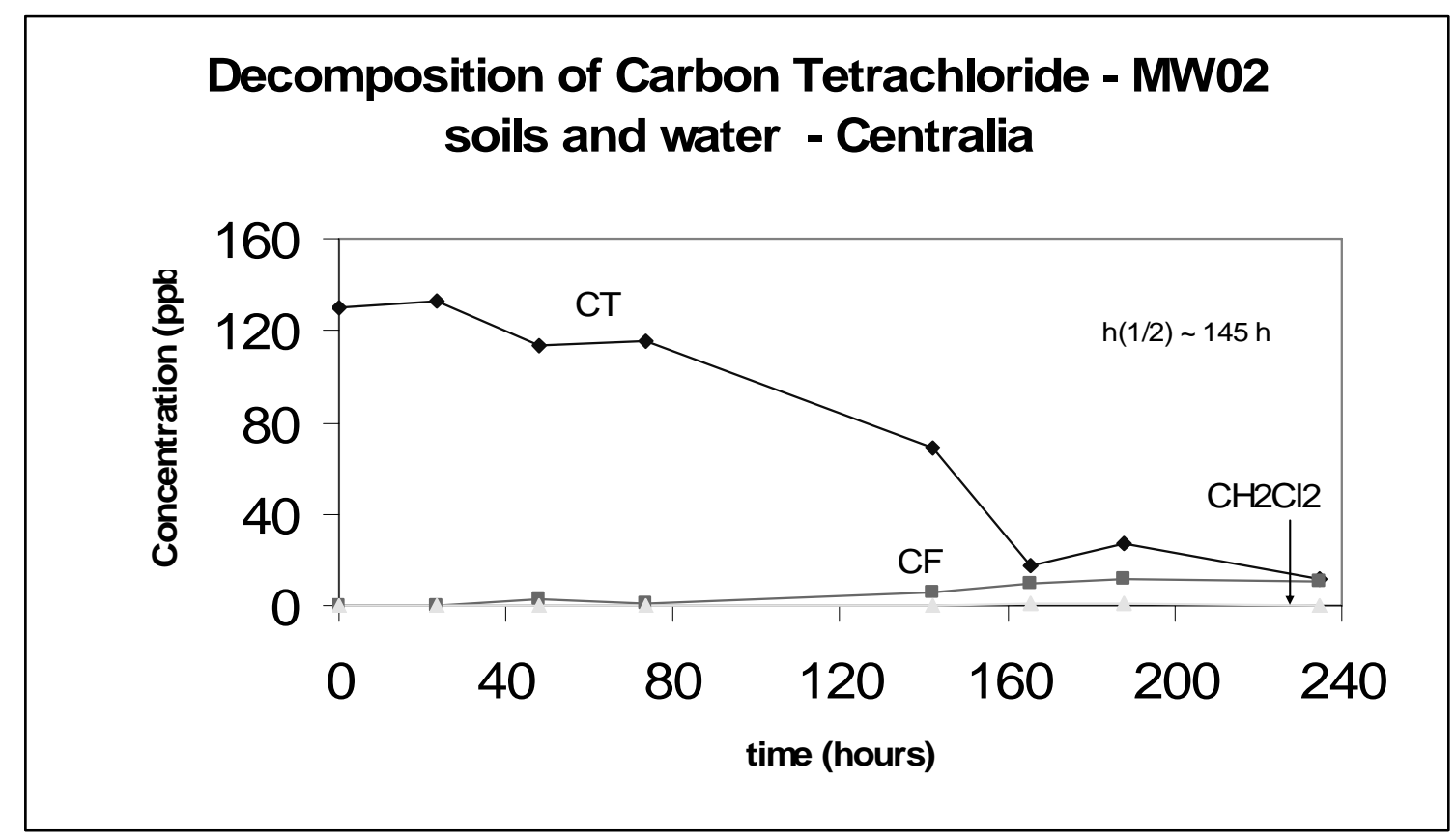

FIGURE B.6 Reaction components: Centralia water $(\mathrm{pH}=7.2)$, EHC-M, Centralia soil, carbon tetrachloride. 


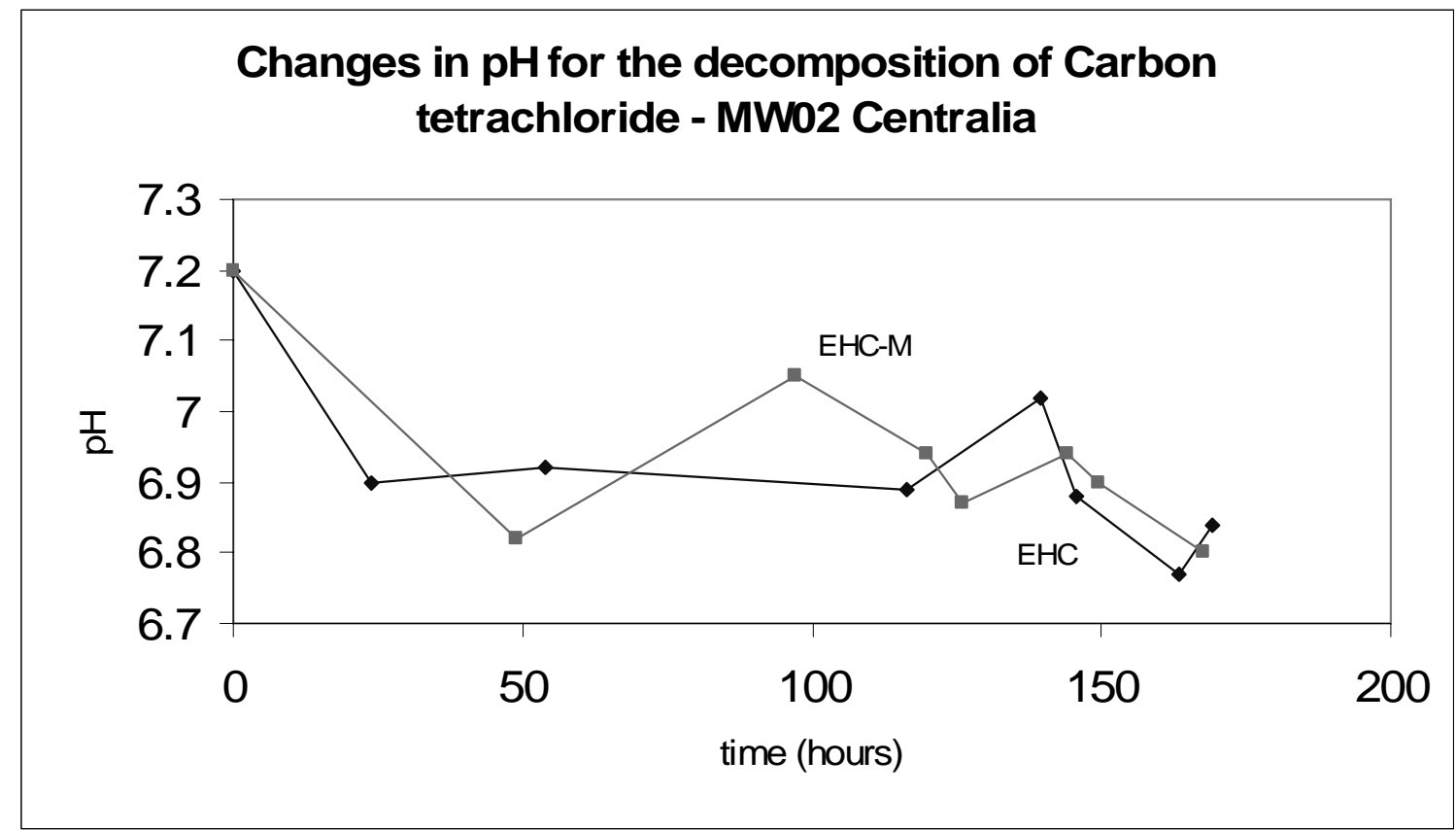

FIGURE B.7 Reaction components: Centralia water $(\mathrm{pH}=7.2)$, EHC or EHC-M, Centralia soil, carbon tetrachloride.

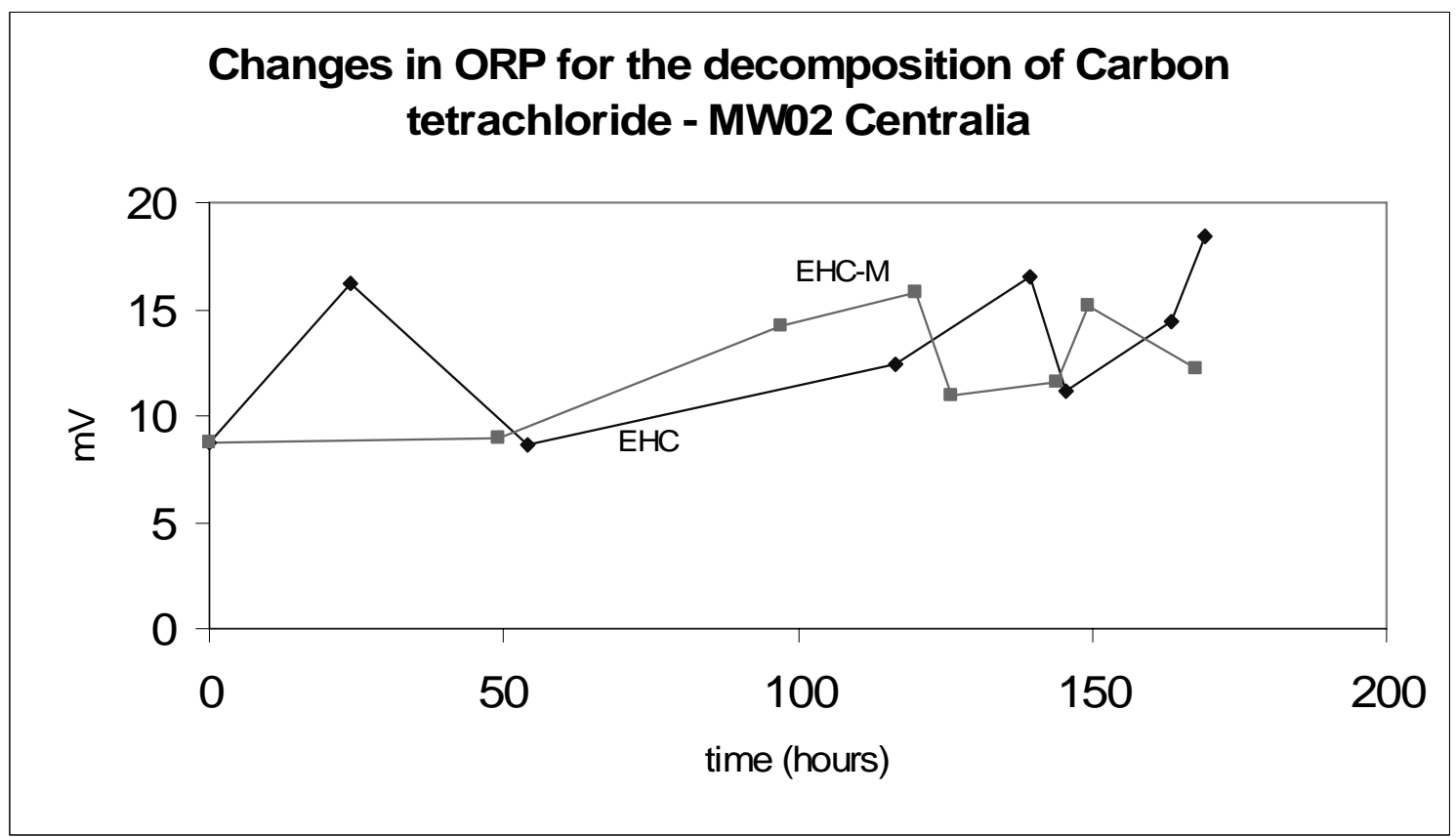

FIGURE B.8 Reaction components: Centralia water $(\mathrm{pH}=7.2)$, EHC or EHC-M, Centralia soil, carbon tetrachloride. 


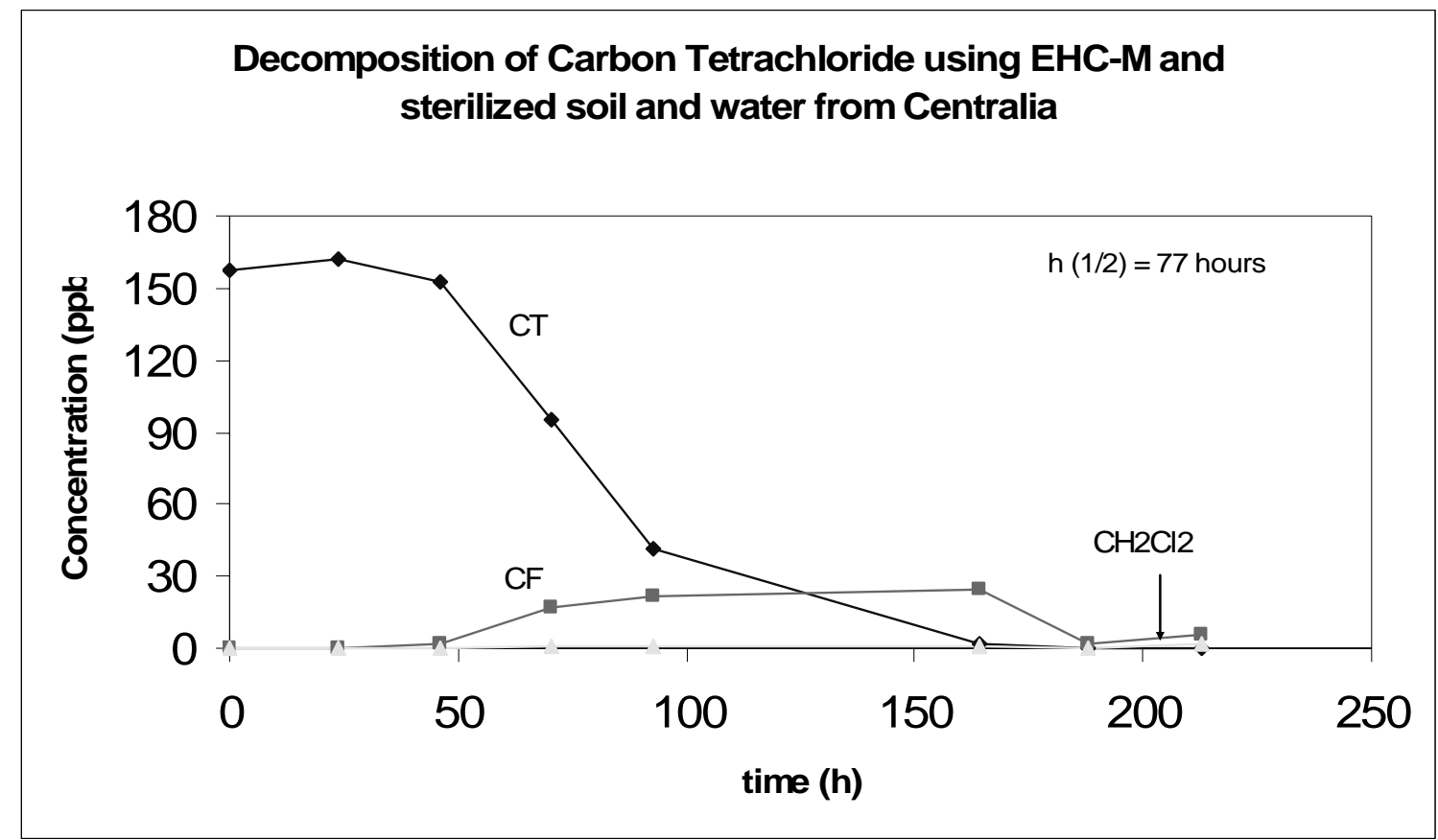

FIGURE B.9 Reaction components: Boiled Centralia water, EHC-M, sterilized Centralia soil, carbon tetrachloride.

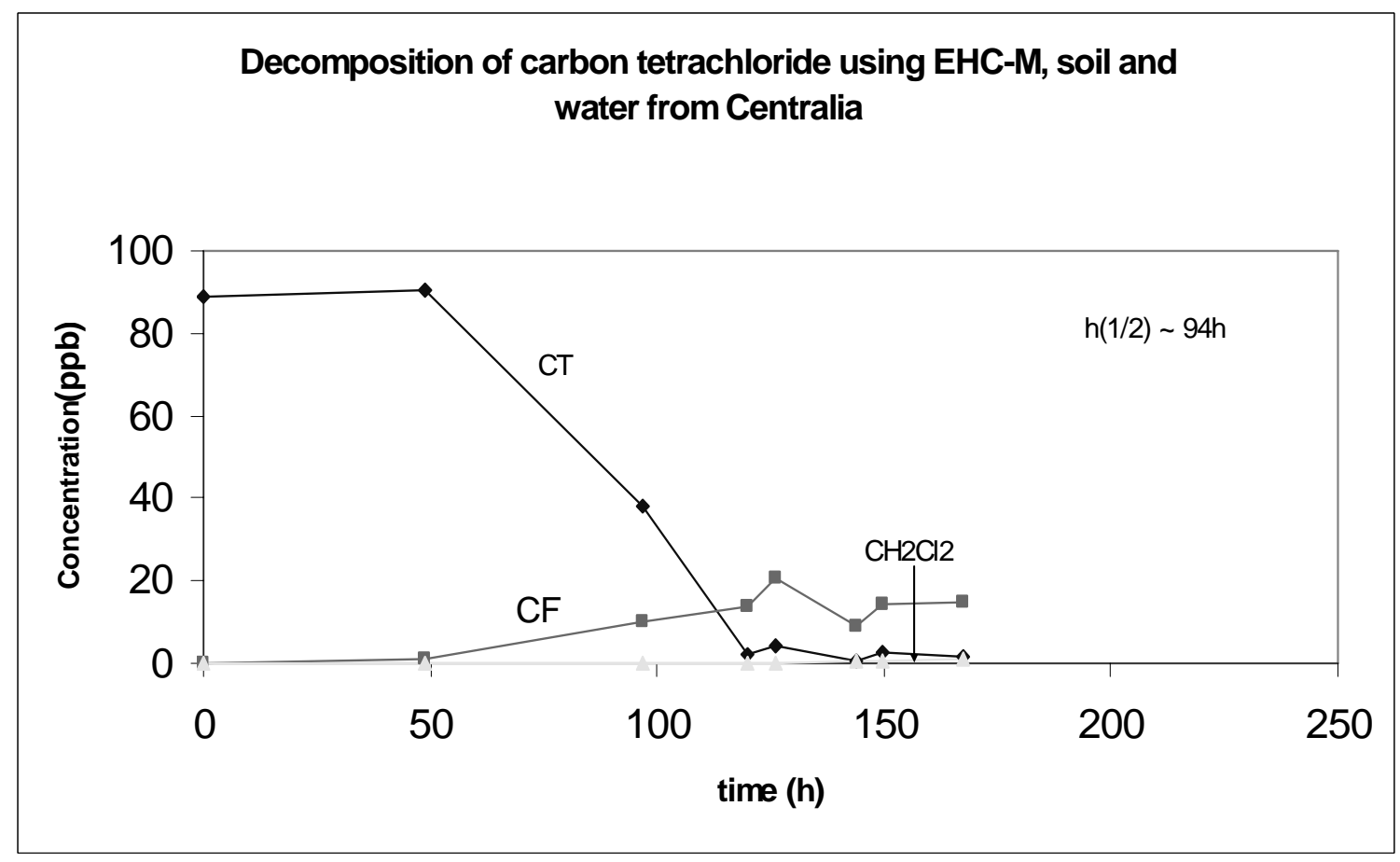

FIGURE B.10 Reaction components: Unboiled Centralia water, EHC-M, unsterilized Centralia soil, carbon tetrachloride. 


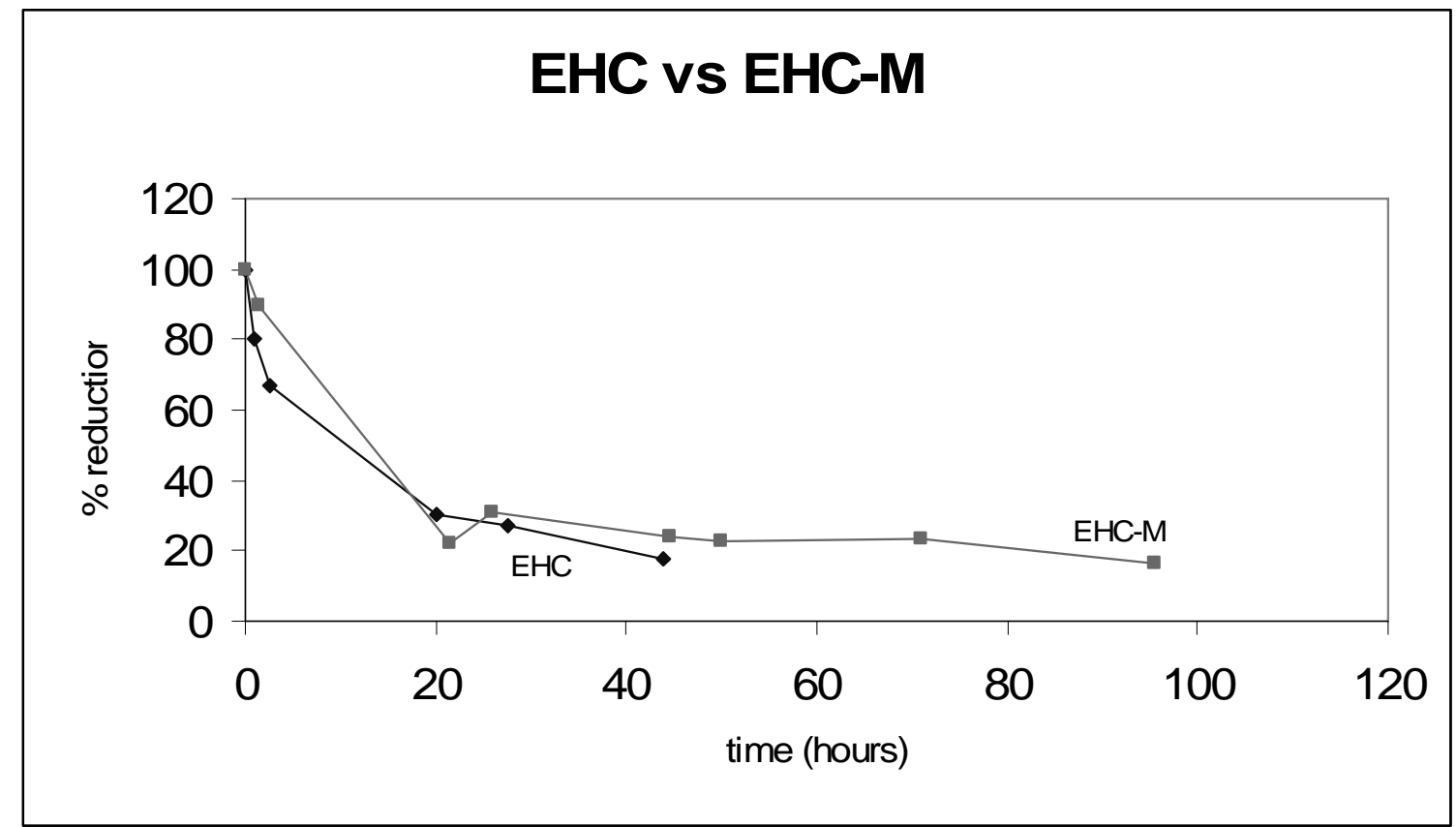

FIGURE B.11 Reaction components: Deionized water, EHC or EHC-M, carbon tetrachloride, hydrochloric acid $(\mathrm{pH}=1)$.

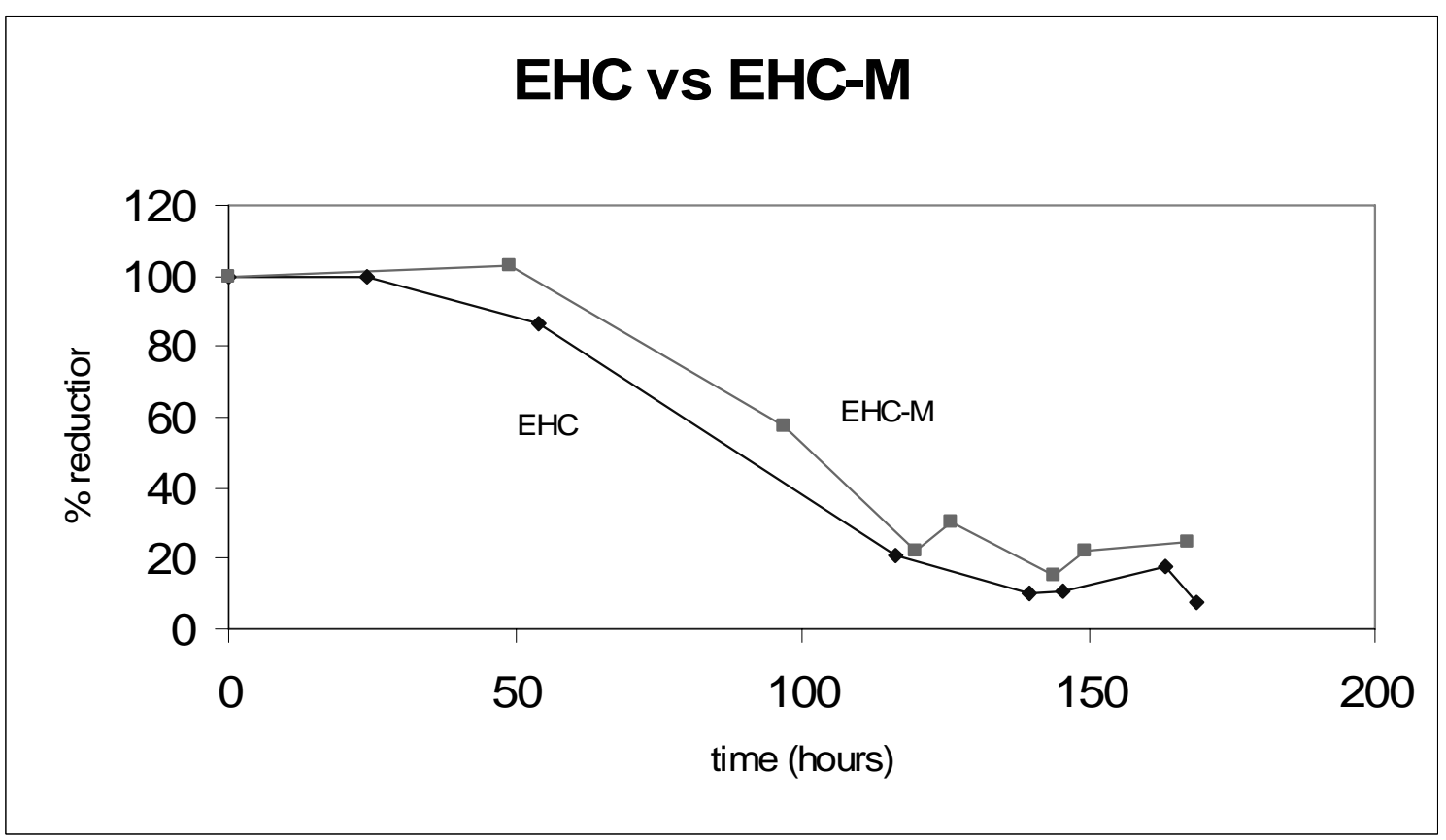

FIGURE B.12 Reaction components: Centralia water, EHC or EHC-M, Centralia soil, carbon tetrachloride. 


\section{Appendix C:}

\section{Material Safety Data Sheets for EHC and EHC-A}




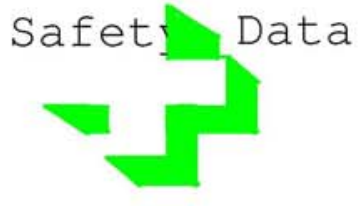

MATERIAL SAFETY DATA SHEET:

\section{PRODUCT IDENTIFICATION: PRODUCT USE:}

\section{MANUFACTURER:}

Adventus Remediation Technologies 1345 Fewster Drive

Mississauga, Ontario

L4W 2A5
ЕНС'м

Bioremediation product for the remediation of contaminated soil and groundwater only. Not for use in potable drinking water.

\section{EMERGENCY PHONE:}

Office Hours: $\quad 905-273-5374$

After Hours: $\quad$ 416-457-9491

TRANSPORTATION OF DANGEROUS GOOD CLASSIFICATION:

Not Regulated

\section{WHMIS CLASSIFICATION:}

Not Regulated

\section{CONTAINMENT HAZARD:}

Any vessel that contains wet $\mathrm{EHC}$ or $\mathrm{EHC}$ and water must be vented due to potential pressure build up from fermentation gasses.

\section{INGREDIENTS}

$\begin{array}{lllcc}\text { CHEMICAL NAME: } & \text { CAS\# } & \text { TLV }(\mathbf{m g} / \mathbf{m} 3) & \text { LD low }(\mathbf{m g} / \mathbf{K g}) & \text { \% in Product } \\ \text { Organic Amendment } & \text { N/D } & \text { N/E } & \text { N/E } & 52-82 \\ \text { Iron } & 7439-89-6 & 5 \text { (as iron oxide fume) } & \text { N/E } & 18-48\end{array}$

\section{PHYSICAL DATA}

Physical state

Odour threshold

Density.

$\mathrm{pH}$

Solubility in water

Coeff. of water/oil

Appearance \& odour
Solid N/A $0.75 \mathrm{Kg} / \mathrm{L}$ N/A Insoluble N/A Odourless, Tan/Brown Flakes
Melting point

Boiling point Vapour pressure $(\mathrm{mm} \mathrm{Hg})$

Vapour density (air=1)

Evaporation rate

$18-48$

4. FIRE AND EXPLOSION HAZARD DATA

FLASH POINT (Deg. C PMCC): N/A

FLAMMABLE LIMITS IN AIR \% BY VOLUME:

$\begin{array}{cc}\text { LOWER } & \text { UPPER } \\ \text { N/A } & \text { N/A }\end{array}$

$1371-1480^{\circ} \mathrm{F}$ $3000^{\circ} \mathrm{C}$ 1 @ $1787^{\circ} \mathrm{C}$ N/A N/A 
AUTO IGNITION TEMP (Deg. C):

EXTINGUISHING MEDIA: Dry chemicals or sand or universal type foam.

\section{SPECIAL PROCEDURES:}

Firefighters should wear SCBA and protective clothing.

\section{UNUSUAL FIRE AND EXPLOSION HAZARDS:}

Dust can present fire and explosion hazards when exposed to fire, chemical reaction, or contact with powerful oxidizers.

\section{REACTIVITY DATA}

STABILITY (NORMAL COND.):

Stable: $X \quad$ Unstable:

CONDITIONS TO AVOID:

Contact with powerful oxidizers such as strong acids.

INCOMPATIBILITY (Materials to Avoid): Powerful oxidizers such as strong acids. HAZARDOUS DECOMPOSITION PRODUCTS: Hydrogen, Carbon monoxide, Carbon dioxide.

6. TOXICOLOGICAL PROPERTIES

ROUTE OF ENTRY:

Inhalation

Ingestion (not likely)

\section{HEALTH HAZARDS:}

Acute overexposure may cause eye, nose, mouth and skin irritation.

Carcinogenicity: No Information Available

Signs and Symptoms of Exposure: No Information Available Medical Conditions Generally

Aggravated by Exposure: $\quad$ No Information Available

7. PREVENTIVE MEASURES

PERSONAL PROTECTIVE EQUIPMENT:

Eye Protection: $\mathrm{X}$ Gloves: $\mathrm{X}$ Clothing:

\section{RESPIRATORY PROTECTION:}




\section{(1) ADVENTUS \\ Proven Soil, Sediment, and Groundwater Remediation Technologies}

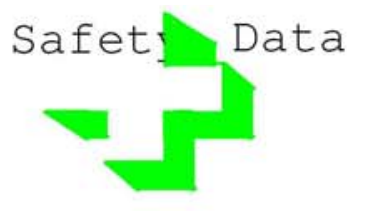

EHC ${ }^{\mathrm{TM}}$

Page: 3 of 3

Use dust mask in severe conditions.

Use good housekeeping practices to keep dust to a minimum.

VENTILATION REQUIREMENTS:

Not normally required.

SPILL AND LEAK PROCEDURES:

Sweep up and return to container.

WASTE DISPOSAL:

Sanitary landfill. Follow Federal, State and Local guidelines.

HANDLING PROCEDURES:

Wear safety glasses for normal use. Avoid generating

excessive dust, wear dust mask in severe conditions.

\section{STORAGE REQUIREMENTS:}

Do not store near powerful oxidizers such as strong acids.

Keep dry.

Any vessel that contains wet $\mathrm{EHC}$ or $\mathrm{EHC}$ and water must be vented due to potential pressure build up from fermentation gasses.

SPECIAL HANDLING INFORMATION:

Treat as a nuisance dust

8. FIRST AID MEASURES

INHALATION: Remove to fresh air. Seek medical attention.

INGESTION: Seek medical attention.

SKIN CONTACT: Brush off excess. Wash with soap and water.

EYE CONTACT: Flush with running water. Seek medical attention.

9. OTHER INFORMATION

None

10. PREPARATION INFORMATION

Prepared By: Adventus Remediation Technologies Date Prep./Rev.: 7/5/07

1345 Fewster Drive

Print Date: $\quad 7 / 5 / 07$

Mississauga, Ontario

Phone: $\quad 905-273-5374$

L4W 2A5

Fax:

905-273-4367

Definitions:

N/D - No Data

$\mathrm{A}=$ Oral rat LD50

N/A - Not Applicable

$\mathrm{B}=$ Oral rat

N/E - Not Established

$\mathrm{D}=$ Estimated 1000

$\mathrm{E}=$ Arbitrary 2000

$\mathrm{F}=$ Other route prefix

$>$ - Greater than

$\mathrm{C}=$ Ceiling limit

EHCTM is a trademark of Adventus Intellectual Property Inc. 
1. PRODUCT IDENTIFICATION: PRODUCT USE:

\section{MANUFACTURER:}

Adventus Remediation Technologies

1345 Fewster Drive

Mississauga, Ontario

LAW 2A5
EHC-A ${ }^{\mathrm{TM}}$

For the remediation of contaminated groundwater only. Not for use with potable drinking water.

\section{EMERGENCY PHONE:}

Office Hours: $\quad 905-273-5374$

After Hours: $\quad 416-457-9491$

TRANSPORTATION OF DANGEROUS GOOD CLASSIFICATION:

Not Regulated

WHMIS CLASSIFICATION:

Not Regulated

CONTAINMENT HAZARD:

Any vessel that contains wet $\mathrm{EHC}$ or $\mathrm{EHC}$ and water must be vented due to potential pressure build up from fermentation gasses.

2. INGREDIENTS

CHEMICAL NAME:

Organic Amendment

Ferrous Sulfate

\section{CAS\#}

N/D

7782-63-0
TLV (mg/m3)

N/E

$\mathrm{N} / \mathrm{E}$
LD low (mg/kg)

N/E

319 (oral rat)

\section{PHYSICAL DATA}

Physical state Solid

Odour threshold N/A

Density.................................... 08 kg/L

$\mathrm{pH}$

Solubility in water. Soluble

Coeff. of water/oil N/A

Appearance \& odour. White Powder, mild sweet odour

\begin{tabular}{|c|c|}
\hline Freezing point. & $0^{\circ} \mathrm{C}$ \\
\hline Boiling point & N/A \\
\hline Vapour pressure $(\mathrm{mm} \mathrm{Hg}) \ldots \ldots . . . \mathrm{N} / \mathrm{A}$ & \\
\hline Vapour density (air=1) & N/A \\
\hline Evaporation rate ......... & \\
\hline
\end{tabular}

4. FIRE AND EXPLOSION HAZARD DATA

FLASH POINT (Deg. C): 250

FLAMMABLE LIMITS IN AIR \% BY VOLUME: AUTO IGNITION TEMP (Deg. C):

$\begin{array}{cc}\text { LOWER } & \text { UPPER } \\ \text { N/A } & \text { N/A } \\ \text { N/A } & \end{array}$




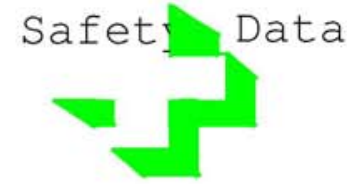

MATERIAL SAFETY DATA SHEET:

EHC-A ${ }^{\mathrm{TM}}$

Page: 2 of 3

EXTINGUISHING MEDIA: Foam, $\mathrm{CO} 2$, Dry chemicals or water.

SPECIAL PROCEDURES: N/A

UNUSUAL FIRE AND EXPLOSION HAZARDS:

N/A

5. REACTIVITY DATA

STABILITY (NORMAL COND.):

Stable: $X \quad$ Unstable:

6. TOXICOLOGICAL PROPERTIES

ROUTE OF ENTRY:

Inhalation

Ingestion

Skin

Eyes

\section{HEALTH HAZARDS:}

Inhalation: Dust irritation, respiratory ailments may be aggravated by dust (allergen)

Skin Contact: Dust irritation

Eye Contact: Dust irritation

Potential Allergen: This product is a potential allergen due to the presence of milk proteins.

\section{EMERGENCY FIRST AID:}

Skin: Wash with soap and water and rinse with water

Eye: Rinse with water, see physician if necessary

Inhalation: Not applicable

Ingestion: Do not provoke vomiting. See physician if necessary

\section{PREVENTIVE MEASURES}

\section{PERSONAL PROTECTIVE EQUIPMENT:}

Gloves: PVC or rubber

Clothing: Good manufacturing practices 


Remediation Technologies
MATERIAL SAFETY DATA SHEET:

Respiratory: Dust mask

Eye: Safety glasses

Footwear: Safety shoes

Engineering Controls: Not applicable

SPILL AND LEAK PROCEDURES:

Sweep up or shovel up and dispose of in a suitable container. Clean area with detergent and rinse.

WASTE DISPOSAL:

In accordance with local, provincial, state and federal regulations

\section{HANDLING PROCEDURES:}

Not applicable.

\section{STORAGE REQUIREMENTS:}

Keep away from heat source, store in cool storage $\left(20^{\circ} \mathrm{C} / 68^{\circ} \mathrm{F}\right)$ with a relative humidity of less than $50 \%$. Avoid storing near strong smelling products.

Any vessel that contains wet EHC or EHC and water must be vented due to potential pressure build up from fermentation gasses.

\section{PREPARATION INFORMATION}

Prepared By: Adventus Remediation Technologies

1345 Fewster Drive

Mississauga, Ontario

L4W 2A5

$\begin{array}{ll}\text { Date Prep./Rev.: } & 10 / 26 / 05 \\ \text { Print Date: } & 10 / 26 / 05 \\ \text { Phone: } & 905-273-5374 \\ \text { Fax: } & 905-273-4367\end{array}$

\section{Definitions:}

N/D - No Data

$\mathrm{A}=$ Oral rat LD50

N/A - Not Applicable

$\mathrm{B}=$ Oral rat

$\mathrm{E}=$ Arbitrary 2000

$\mathrm{D}=$ Estimated 1000

$\mathrm{C}=$ Ceiling limit
N/E - Not Established
$<-$ Less than
LD low $\mathrm{C}=$ Oral LD50/LD low other animal > - Greater than
$\mathrm{F}=$ Other route prefix

EHC ${ }^{\text {TM }}$ is a trademark of Adventus Intellectual Property Inc. 
Argonne

Environmental Science Division

Argonne National Laboratory

9700 South Cass Avenue, Bldg. 203

Argonne, IL 60439-4843

www.anl.gov

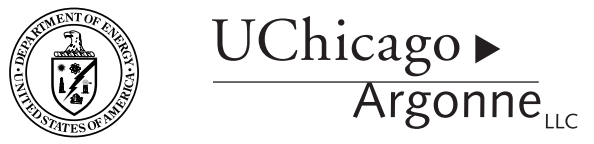

A U.S. Department of Energy laboratory managed by UChicago Argonne, LLC 